\title{
Decapod Crustacean Larvae from Ungava Bay
}

\author{
Hubert J. Squires \\ 122 University Avenue, St. John's \\ Newfoundland, Canada, A1B 1 Z5
}

\begin{abstract}
The MV CALANUS expeditions to Ungava Bay during 1947-51 collected from the plankton approximately 11000 specimens of larvae of decapod crustaceans comprising 12 species. The larval stages of these species are described and drawings made in detail from the specimens taken.

As representative species of the eastern Canadian Arctic and northwestern Atlantic, they are compared briefly with the same species from the eastern Atlantic and Pacific. Characteristics of eight species of the Hippolytidae, four of the Pandalidae, three of the Crangonidae, two of the Paguridae and two of the Majidae from the northwestern Atlantic are summarized and keys given for their identification.
\end{abstract}

Keywords: Canadian eastern Arctic, Crangonidae, decapod larvae, Hippolytidae, Hyas, Northwest Atlantic, Paguras, Pandalidae 



\section{Introduction}

The present work on decapod larvae is a supplement to my publication on adult decapod crustaceans of the Atlantic coast of Canada (Squires, 1990), although the number of species treated is considerably less. Its primary purpose is to describe in detail larval stages of 12 species of decapod Crustacea taken from the plankton in Ungava Bay, northern Quebec, Canada. The decapod larvae presented in this report were collected on the MV CALANUS expeditions by M. J. Dunbar and E. H. Grainger and their associates at McGill University in Eastern Arctic Investigations of the Fisheries Research Board of Canada during 1947-51 in Ungava Bay (Dunbar and Grainger, 1952; Fontaine, 1955; Squires, 1957). Ungava Bay is a large bay, about $220 \mathrm{~km}$ across at its mouth and extending about $240 \mathrm{~km}$ in length, between approximately $58^{\circ} \mathrm{N}$ and $61^{\circ} \mathrm{N}$ latitude, and $65^{\circ} \mathrm{W}$ and $70^{\circ} \mathrm{W}$ longitude at Hudson Strait (Fig. 1). Stations where collections were made are listed in Table 1 and 9 and precise positions are available in maps in Dunbar and Grainger, 1952, and Grainger, 1954.

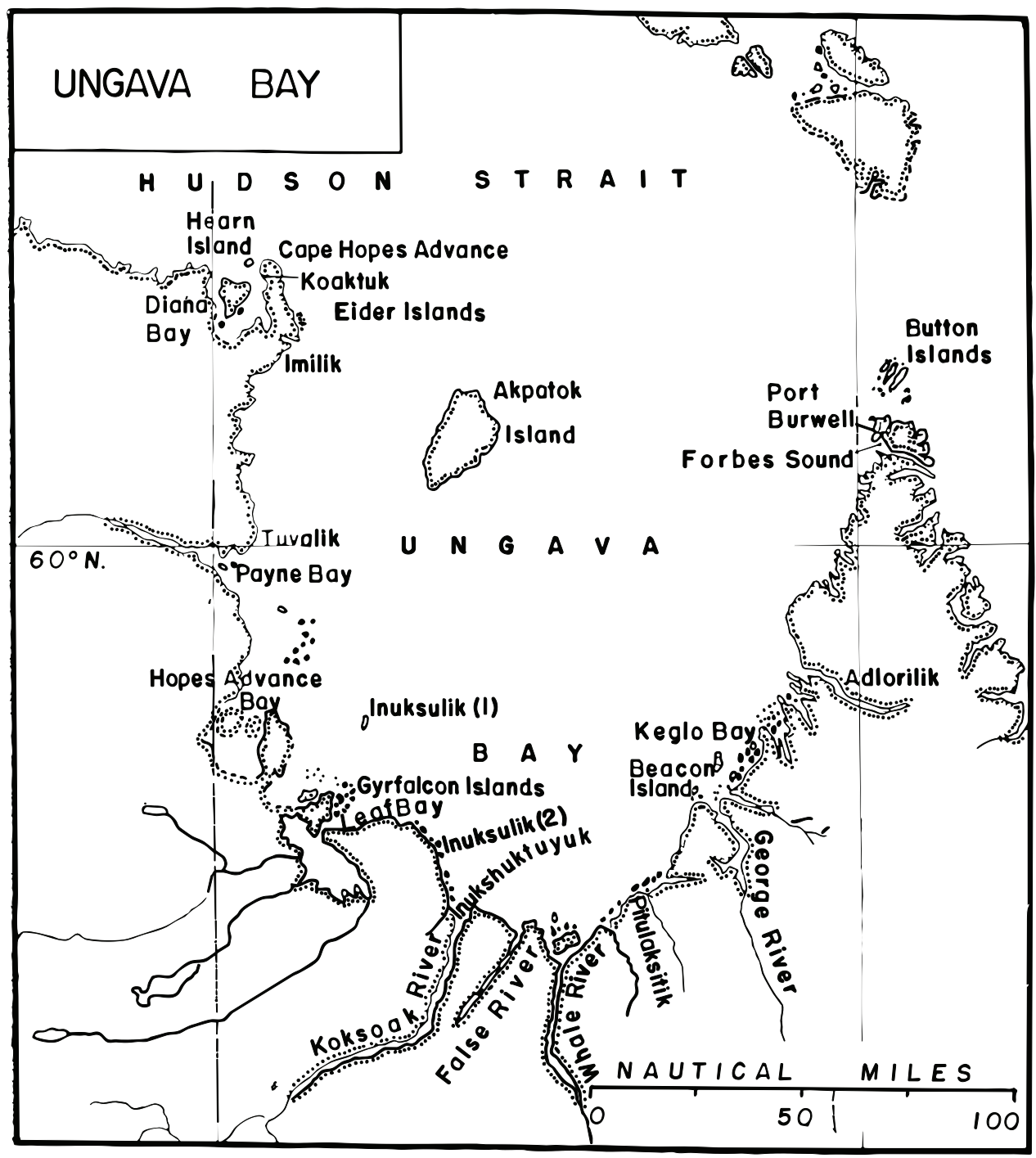

Fig. 1. Map of Ungava Bay from Dunbar and Grainger (1952). 
Only 20 species of adult decapod crustaceans have been reported from Ungava Bay (Squires, 1966), some of which were taken in very small numbers. The number of species taken as larvae in the plankton were even fewer; only 12 species were found in about 11000 specimens. In this instance the few species was an advantage since it allowed separation of larvae of closely related species somewhat easier than if there were many species in the plankton.

Larvae of most of these species have already been described from the eastern Atlantic or the eastern Pacific but not from the western Atlantic or the Arctic: the arctic conditions under which they live in Ungava Bay could be expected to affect them, especially with regard to their size at various stages (most of them are larger at corresponding stages than those of the eastern Atlantic). The present descriptions give some new information and may help in the identification of some confusing members of commonly occurring families in the western Atlantic. Among the Hippolytidae for example, there is confusion between the species Spirontocaris phippsi and S. spinus. Comparison of these larvae with those of the same species from the eastern Atlantic gives some striking differences that would make their identification difficult if based entirely on the descriptions formerly given in the literature.

Named specimens at each stage for the species are deposited at the Canadian Museum of Nature, Ottawa, and at the Atlantic Reference Centre, Huntsman Marine Science Centre, St. Andrews, N. B.

\section{Materials and Methods}

Measurements of larvae were made in water in a petri dish resting on a square-millimetre grid. An estimate of length was made to the nearest $\mathrm{mm}$ where the larva lay on the slide. Total length (t) referred to in this paper is taken from the tip of the rostrum to the tip of the telson, the latter exclusive of spines or setae (from the tip of the rostral spine to the tip of the dorsal spine in Spider Crab, (Hyas coarctatus) larvae).

I did some of the early work on these larvae from whole mounts (the mouthparts and other appendages dissected out and included with the whole specimen) in a Fisher-Littman well slide, stained after partial dehydration (in 70\% alcohol) with Chlorazol Black E and mounted in Permount after complete dehydration in Xylene. The slides were stored flat because the body parts would otherwise drift together in the medium. I did later work entirely from unmounted specimens stained with Acid Rose and examined with a dissecting microscope.

Description of larvae of decapod crustaceans. Although the morphology of mouth parts, etc., of decapod crustaceans is similar in the larvae as in the adults of shrimps (a generalized description of body parts is given in Squires (1990) but see also figures of each larval stage in this paper), there are differences in structure caused by growth and development from a mostly simple form in the larva to more complex forms as the larva moults and progresses through the developmental stages. In the present species there are usually four larval stages (only two in some) and a Megalopa which begins to look like the adult form in shrimps but less so in crabs.

Stages of the larvae. The stages of larvae in the species collected from Ungava Bay were characterized based on documented descriptions in literature as follows:

Stage I Zoea - the eye-stalks and eyes are attached to the carapace along one side. The telson is triangular with faintly visible and small uropods enclosed, and it is sometimes not clearly separated from the fifth abdominal somite.

Stage II Zoea - the eye-stalks and eyes are free from attachment except at their bases. The uropods are still enclosed but clearly visible and large in the telson which is roughly triangular in shape and separated from the fifth somite. 
Stage III Zoea - the uropods are free from the telson which is still subtriangular in shape, but the inner branch or endopod of the uropod is small and undeveloped.

Stage IV Zoea - the uropods have both branches, the exopod and endopod, well-developed and separated from the telson. The edges of the telson are parallel.

Stage $V$ and subsequent Zoeal Stages - these have additional features depending upon the species.

Megalopa - the larva has fully developed setose pleopods, the second maxilliped similar to that of the adult, and the antennal flagellum is well developed. In shrimps it may still moult through several stages before the juvenile stage is reached (Haynes, 1985).

External morphology of the larvae. As in the adults, the structures in larval decapod crustaceans include the following (as shown in the Figures according to the lettering):

(a) the carapace, the anterior covering of the body including the rostrum which is the pointed anterior dorsal extension or spine. The carapace covers the head and the eight thoracic segments with various appendages. The abdomen is the narrow cylindrical tail-part of the body bearing the pleopods ventrally and the telson (t) posteriorly.

(b) the eyes, the compound eyes are usually stalked attachments at the anterior end of the carapace.

(c) the antennules, are the first pair of appendages with peduncle and two flagella. These are the sensory organs, bearing plumose setae and aesthetes (Gurney, 1942, p. 125).

(d) the antennae, with scale (exopod) and one flagellum (endopod). These are also mainly sensory in function.

(e) the mandible, the short and heavy appendage with grinding and biting surfaces for feeding.

(f) the maxillule, this is the first of the series of accessories to mouthparts, contains two endites, proximal and distal (coxal and basal), and an endopod. The distal endite has two or more rows of short, sharp, spine-like setae at its leading edge for triturating food as well as pushing it into the mouth.

(g) the maxilla, this has lobed endites, proximal and distal, as above, an endopod, and the scaphognathite (exopod) with long plumose setae and an anterior and posterior lobe. The scaphognathite acts as a water bailer, moving water over the gills.

(h) the first maxilliped, this also is with endites, an endopod, epipod and long exopod, with long apical natant setae used for swimming.

(i) the second maxilliped, this is with endopod, epipod and long exopod with long apical setae used for swimming.

(j) the third maxilliped, this is with endopod, epipod and long exopod with long apical setae used for swimming.

Then follow the pereopods or legs - first pereopod $(I)$, second pereopod $(m)$, third pereopod $(n)$, fourth pereopod (n') and fifth pereopod (n"). These may be budlike in early larval stages, and may or may not bear an exopod or epipod. 
The next are the pleopods. The first and second pleopods (o, $\mathrm{p}$, respectively) may be buds or non-existent in early stages of some species or may be unbranched (uniramous) or branched (biramous), sometimes bearing an appendix interna, a projection at the inner side of the endopod, in late larval stages.

Setae commonly occurring on the body and appendages are articulated the base or sutured and may be slender, or thick and annulated and with or without small lateral projections or plumes (plumose), or they may be short, stout and spine-like, and sometimes referred to as spines. Spines are generally not articulated at base. (Various kinds of setae are elaborated by Pohle and Telford (1981)). The plumes are not put in on the setae in some of the drawings in this paper but are mostly mentioned in the text. 


\title{
List of Species of Decapod Crustacean Larvae Taken in Ungava Bay
}

\author{
Suborder EUKYPHIDA Boas, 1880 \\ Infraorder CARIDEA Dana, 1852 \\ Family HIPPOLYTIDAE Dana, 1852
}

Eualus fabricii (Krøyer, 1842)

Eualus gaimardi ( $\mathrm{H}$. Milne-Edwards, 1837)

Lebbeus groenlandicus (Fabricius, 1775)

Lebbeus polaris (Sabine, 1821)

Spirontocaris phippsi (Krøyer, 1842)

Spirontocaris spinus (Sowerby, 1805)

Family PANDALIDAE Haworth, 1825

Pandalus borealis (Krøyer, 1838)

Pandalus montagui (Leach, 1814)

Family CRANGONIDAE H. Milne-Edwards, 1837

Argis dentata (Rathbun, 1904)

Sabinea septemcarinata (Sabine, 1824)

Suborder REPTANTIA Boas, 1880

Infraorder ANOMURA H. Milne-Edwards, 1832

Family PAGURIDAE Latreille, 1803

Pagurus pubescens (Krøyer, 1838)

Infraorder BRACHYURA Latreille, 1803

Family MAJIDAE Samouelle, 1819

Hyas coarctatus (Leach, 1815) 



\section{Key to Families of Decapod Larvae Present in Ungava Bay}

(Adapted from Hart, 1971)

1. Carapace globular; only exopods of first and second maxillipeds with swimming setae

- Carapace elongate, shrimp-like; exopods of more than first and second maxillipeds with swimming setae

2. Telson forked with two spines at base of each fork; no uropods at any zoeal stage; rostrum a long spine, also a long posterior dorsal spine, and lateral spines, all armed with denticles

- Telson not forked with uropods at later stages; only rostral spine long,no dorsal spine or lateral spines but a spine at each posterior corner of carapace

3. Rostrum slender, tapered from wide base and toothed in later stages; eye-stalks tapered toward base; antennules slender with bases widely separate

- Not so

4. Rostrum narrow; eye-stalks cylindrical and slightly tapered; antennules with bases separated by less than their individual width

- Rostrum broad; eye-stalks hemispherical and almost touching in midline; antennules with bases touching 



\title{
Key to Genera and Species of Decapod Larvae Present in Ungava Bay
}

\author{
(From observations and various authors. Tables 4-12) \\ Larvae of species shown in parentheses not taken in Ungava Bay
}

1. Carapace somewhat globular and with large spines, abdomen slender, curved backward

- Carapace and abdomen elongate, shrimp-like

2. Telson forked and without uropods; carapace with long rostral, posterior dorsal and lateral spines Hyas

- Telson truncate and with uropods in later stages; carapace with only a long rostral spine Pagurus

3. Zoea with about one-third of dorsal and rostral spines covered with minute spinules shorter than the width of the spine where attached (Hyas araneus)

- Zoea with about one-third of dorsal and rostral spines covered with stout spinules longer than the width of the spine where attached Hyas coarctatus

4. Antennal flagellum styliform (Pagurus acadianus)

- Antennal flagellum bifid Pagurus pubescens

5. Abdomen with a dorsolateral spine on somites 4 and 5 or on somite 5 only 7,8

- Abdomen without dorsolateral spine on any somite .. Pandalus

6. Stages I and II Zoea about 6-7 $\mathrm{mm}$ in total length; Stages II and III with many setae on antennal scale and scaphognathite Pandalus borealis

- Stages I and II Zoea about 4-5 mm in total length; Stages II and III with few setae on antennal scale and scaphognathite Pandalus montagui

7. Dorsolateral spine on abdominal somite 5 only (not in Ungava Bay)

- Denticles on abdominal somites 4 and 5 (Pandalus propinquus)

- Denticles on abdominal somites 3 and 4 (Dichelopandalus)

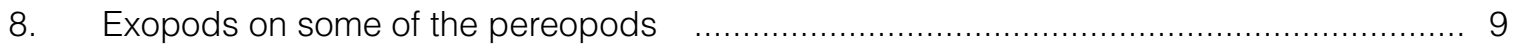

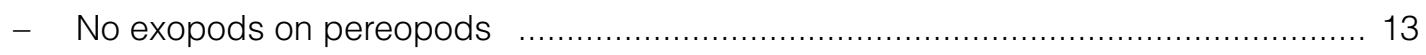

9. Exopods on first to third or first and second pereopods

- Exopods on first to third pereopods

Eualus..... 10 
- Exopods on first and second pereopods

10. Total length of Stage I Zoea about $5 \mathrm{~mm}$

- Dorsolateral spines on abdominal somites 4 and 5

Eualus fabricii

- Dorsolateral spines on abdominal somite 5 only

Eualus gaimardi

11. Total length of Stage I Zoea $3 \mathrm{~mm}$ or less

- Total length of Stage I Zoea $3 \mathrm{~mm}$; spines on telson 7+7

(Eualus macilentus)

- $\quad$ Total length of Stage I Zoea $2 \mathrm{~mm}$; spines on telson 6+6

(Eualus pusiolus)

12. Exopods on first and second pereopods only

Spirontocaris

- Stages I and II Zoea about 6-7 mm total length; many setae on anterior lobe of scaphognathite; centre pair of terminal spines of telson not much smaller than others Spirontocaris phippsi

- Stages I and II Zoea less than $6 \mathrm{~mm}$ total length; relatively few setae on anterior lobe of scaphognathite; central pair of terminal spines on telson much smaller than others in Stages I-IV

13. Very large Zoeae, Stages I and II about 9-11 mm or more in total length; chela of first pereopod pre-subchelate

- Moderately large Zoeae, Stages I and II about 8-9 mm or less in total length; chela of first pereopod clearly chelate Lebbeus

14. Terminal spines of telson $11+11$

Lebbeus groenlandicus

- Terminal spines of telson $9+9$

Lebbeus polaris

15. Pleopods well developed in Stage I Zoea; expansion present on outer edge of first article of antennule in Stage II 16

- Pleopods not developed in Stages I or II Zoea; expansion lacking on outer edge of first article of antennule in Stage II

(Crangon septemspinosa)

16. Dorsolateral spine on abdominal somite 5 only Argis dentata

- Dorsolateral spines on all abdominal somites Sabinea septemcarinata 


\section{Suborder EUKYPHIDA \\ Infraorder CARIDEA \\ Family HIPPOLYTIDAE \\ PANDALIDAE \\ CRANGONIDAE}





\section{Suborder Eukyphida Boas, 1880 Infraorder CARIDEA Dana, 1852 \\ Family HIPPOLYTIDAE Dana, 1852}

The larvae of this family occurred frequently in the CALANUS collections in Ungava Bay. The larvae are characterized by a narrow rostrum, cylindrical eye-stalks, and antennules with bases separated by less than their individual width (Hart 1971). Haynes (1985) indicates that in Stages IIII, the amount of separation of bases of antennules is not entirely reliable, but that the abdomen of hippolytids appears shorter and the antennules appear to turn upwards more than in pandalids which they may otherwise resemble (Haynes, 1985).

\section{Genus Eualus Thallwitz, 1892}

Haynes 1985: 276.

Larvae of this genus may be distinguished from other larvae in the area by the presence of exopods on the first to third pereopods. Species (adults) present in Ungava Bay comprise $E$. fabricii, E. gaimardi (also E. g. belcheri), and E. macilentus (very few in number of the latter were taken; Squires, 1957).

\section{Eualus fabricii (Krøyer, 1841)}

Haynes, 1981: 430, fig. 5; 1985: 276.

Dorsolateral spines on the abdominal somites 4 and 5 distinguish the larvae of this species from others of the genus (Haynes, 1981 and 1985) (Table 4). Total lengths of Stages I and II appear greater in the Ungava Bay specimens examined than in the Pacific specimens of Haynes (1981); length ranges were $5.0-6.6 \mathrm{~mm}$ compared to $3.5-4.3 \mathrm{~mm}$. Total lengths $(\mathrm{mm})$ at the different zoeal Stages were as follows: I. 5.0-5.5; II. 5.0-6.6; III. 6.4-7.8; IV. 8.0

Distribution in Ungava Bay: larvae were taken mostly on the east side of the bay; west of Akpatok Island, Inuksulik, Leaf Bay, Koksoak River mouth, Beacon Island, Adlorilik and near Port Burwell (Fig. 1; Table 1). No. of specimens taken $=57$ (Table 2).

\section{Description}

Stage I Zoea. (Fig. 2, 3)

Carapace (a): carapace to abdomen ratio 1:3.8. Small median tubercle near base of rostrum and one near posterior edge of carapace; small supraorbital spine; two denticles and strong pterygostomial spine at anteroventral edge. Rostrum enlarged at base, horizontal, reaching end of first article of antennule (two articles only).

Abdomen: with dorsolateral spines on somites 4 and 5.

Antennule (c): with 2 basal articles and short terminal pre-flagella the larger pointed and with 4 aesthetes, the smaller with apical setae one of which is plumose.

Antenna (d): with flagellum about as long as scale and with sharp spinous tip. Scale with 12 plumose setae and 1 distolateral spine, the latter much shorter than the blade.

Mandibles (e): with no palp. Incisor with four sharp teeth, separated from molar by thin edge with a couple of teeth. 


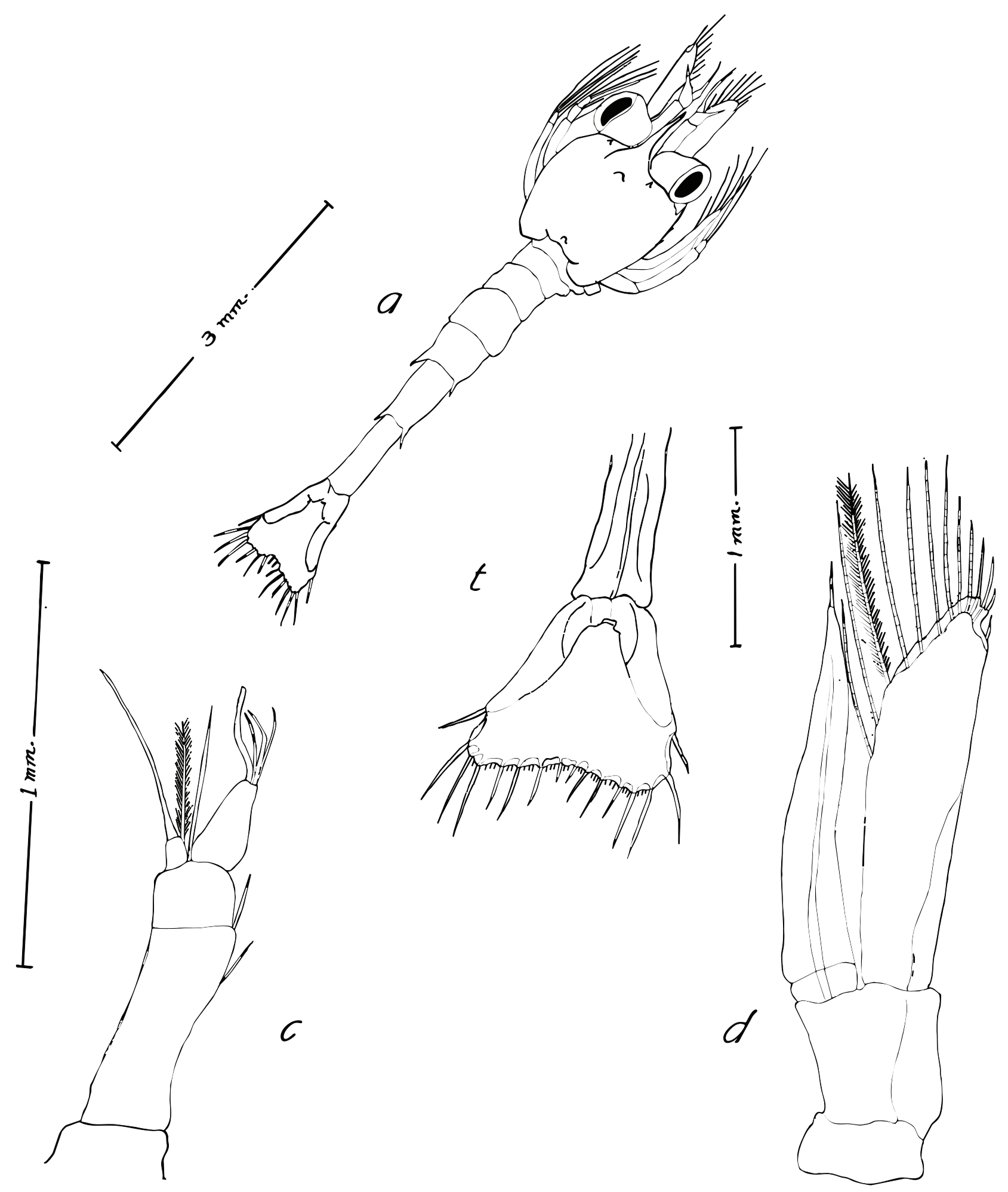

Fig. 2. Eualus fabricii, Stage I Zoea: (a) whole zoea from left side; (t) telson; (c) antennule; (d) antenna. Scales as indicated. 

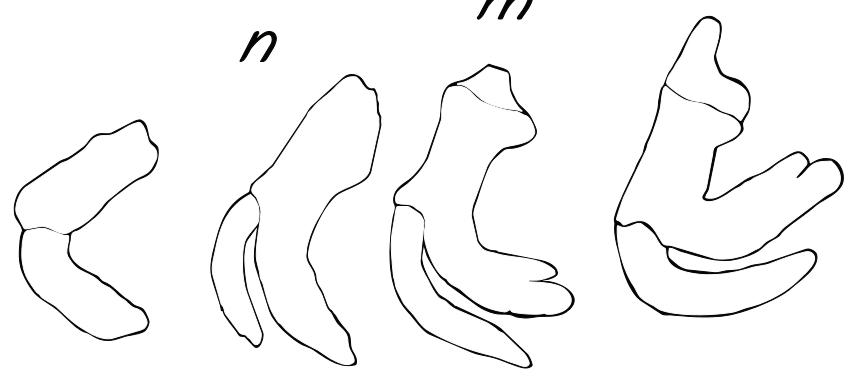

$m$
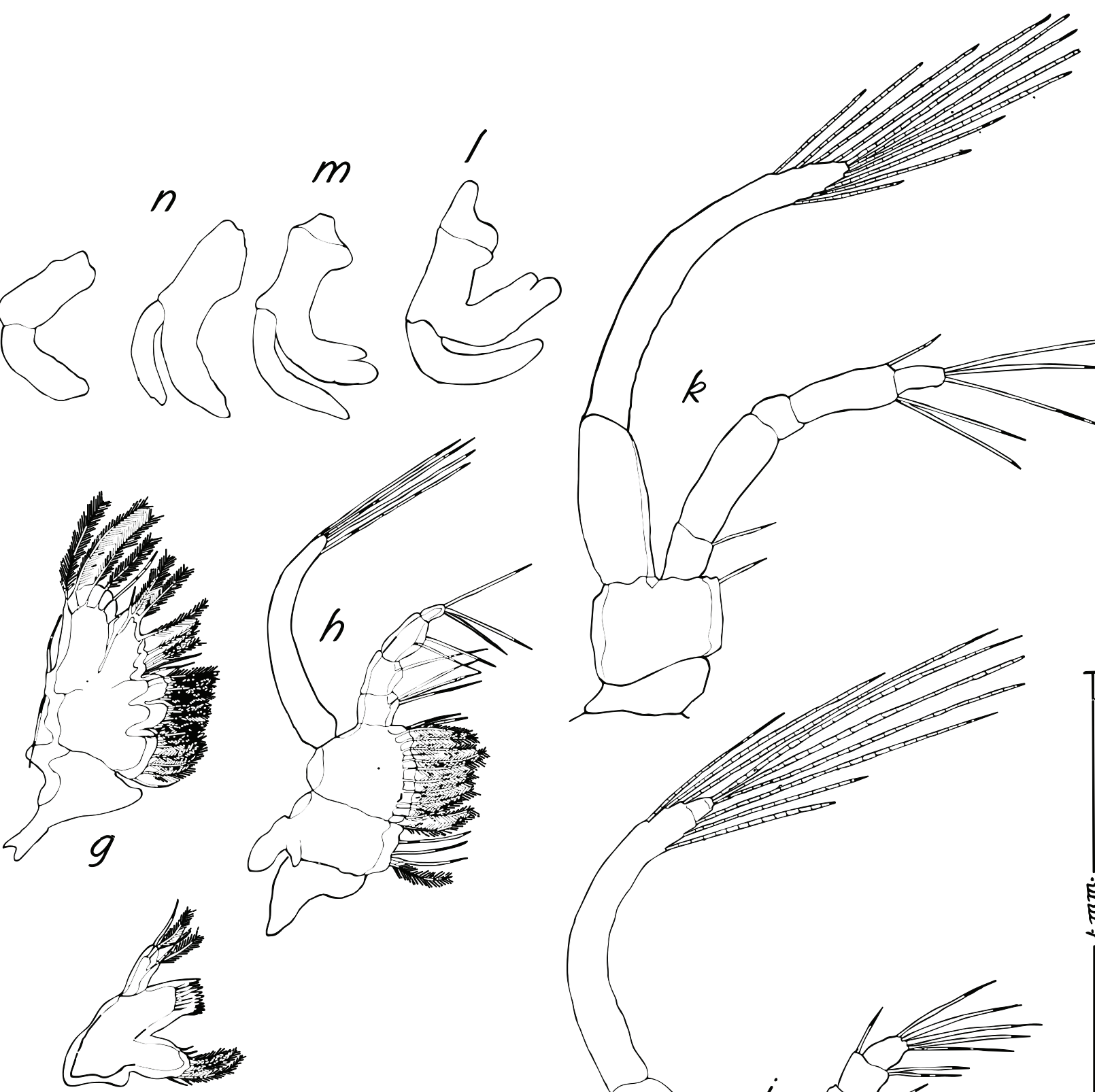

$f$
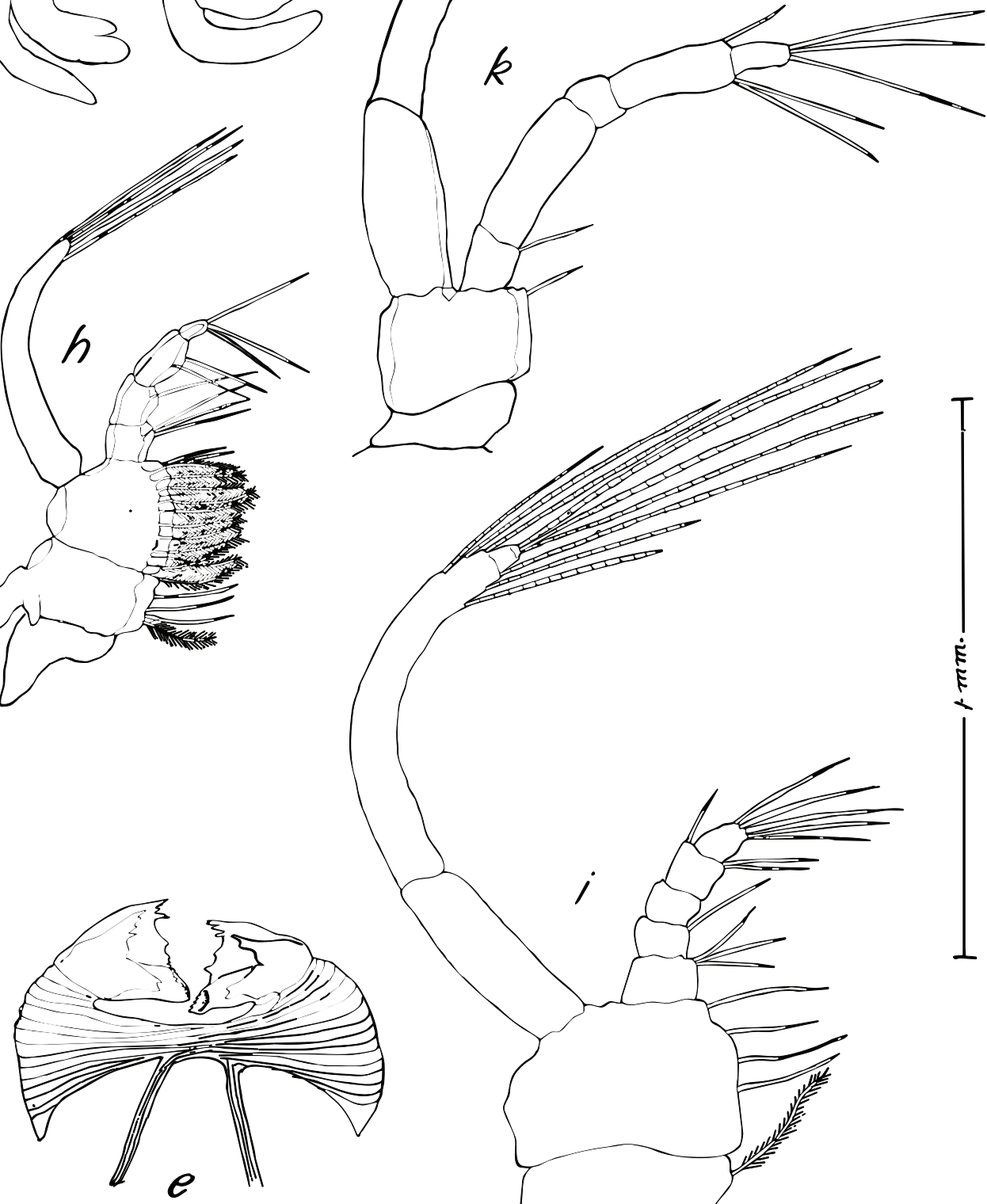

Fig. 3. Eualus fabricii, Stage I Zoea: (e) mandibles; (f) maxillule; (g) maxilla; (h) first maxilliped; (i) second maxilliped; (k) third maxilliped; (I) first pereopod; (m) second pereopod; (n) third pereopod. Scale as indicated. 
Maxillule (f): proximal endite thin and slightly curved with 4 plumose and 3 simple setae; distal endite with 14 stout setae in two rows. Endopod with 3 terminal and 2 lateral setae.

Maxilla (g): proximal endite with large and small lobes; distal endite with equal lobes, all with long plumose setae. Endopod with 3 terminal and 6 lateral plumose setae. Scaphognathite with 6 apical plumose setae and posterior lobe small with an anterior and a posterior long seta.

First maxilliped (h): with wide slightly unequal endites with long lateral plumose setae. Endopod with 4 divisions, with lateral and terminal setae (proximally to distally 3, 1, 2, 3). Exopod long with 4 terminal setae; epipod two-lobed, short.

Second maxilliped (i): endopod short with five divisions and 3, 1, 0, 3 and 5 simple setae. Exopod much longer with two divisions and 11 segmented apical setae.

Third maxilliped (k): proximal and distal endites with 0 and 1 setae respectively. Endopod almost as long as exopod with 5 divisions and 1, 0, 0, 3 and 3 setae. Exopod long with 2 divisions and 11 apical setae.

Pereopods: first $(I)$, second $(m)$ and third $(n)$ with exopod; fourth and fifth without exopod.

Pleopods: short buds only.

Telson (t): slightly notched, with 8 pairs of setae.

Dates of occurrence in plankton hauls: 26 June-14July (Table 3).

Stage II Zoea. Total length 5.8 mm (Fig. 4).

Differences between this Stage and Stage I are as follows: rostrum is slightly longer, reaching middle of 2 nd article (three articles present) of antennule. Small supraorbital spine not present in some specimens, front part of carapace somewhat raised. No anteroventral teeth behind pterygostomian spine.

Antennule (c): with three articles.

Antenna (d): scale may have one segment near tip, about 16 fringing setae, tip of flagellum a long attenuate spine exceeding scale.

Maxilla (g): scaphognathite anterior lobe with about 7 plumose setae and very short posterior lobe with a terminal seta.

Pereopods $(\mathrm{I}, \mathrm{m}, \mathrm{n})$ : with exopods, endopods showing some primary segmentation.

Pleopods: still budlike.

Dates of occurrence in plankton hauls: 26 June-20 July (Table 3).

Stage III Zoea. Total length 7.5 mm (Fig. 5).

Carapace (a): with supraorbital, antennal and pterygostomial spines, also median anterior and posterior tubercles. Rostrum styliform, long, reaching beyond eyes to distal edge of first article of antennule.

Abdomen: with dorsolateral spines on somites 4 and 5. 


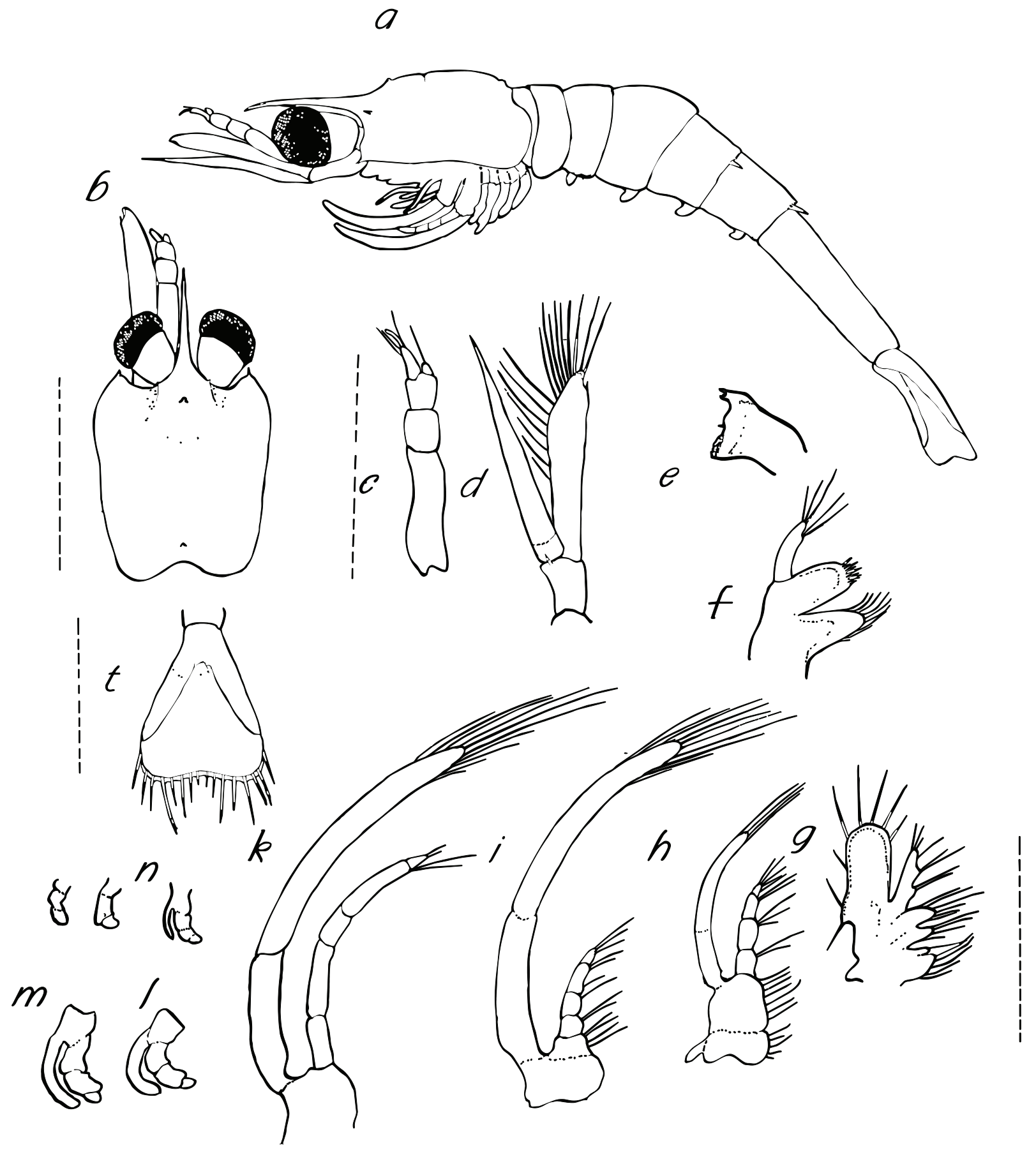

Fig. 4. Eualus fabricii, Stage II Zoea: (a) whole zoea from left side; (b) dorsal carapace; (c) antennule; (d) antenna; (e) mandible; (f) maxillule; (g) maxilla; (h) first maxilliped; (i) second maxilliped; (k) third maxilliped; (I) first pereopod; (m) second pereopod; (n) third pereopod; (t) telson. Broken line $=1 \mathrm{~mm}$. 


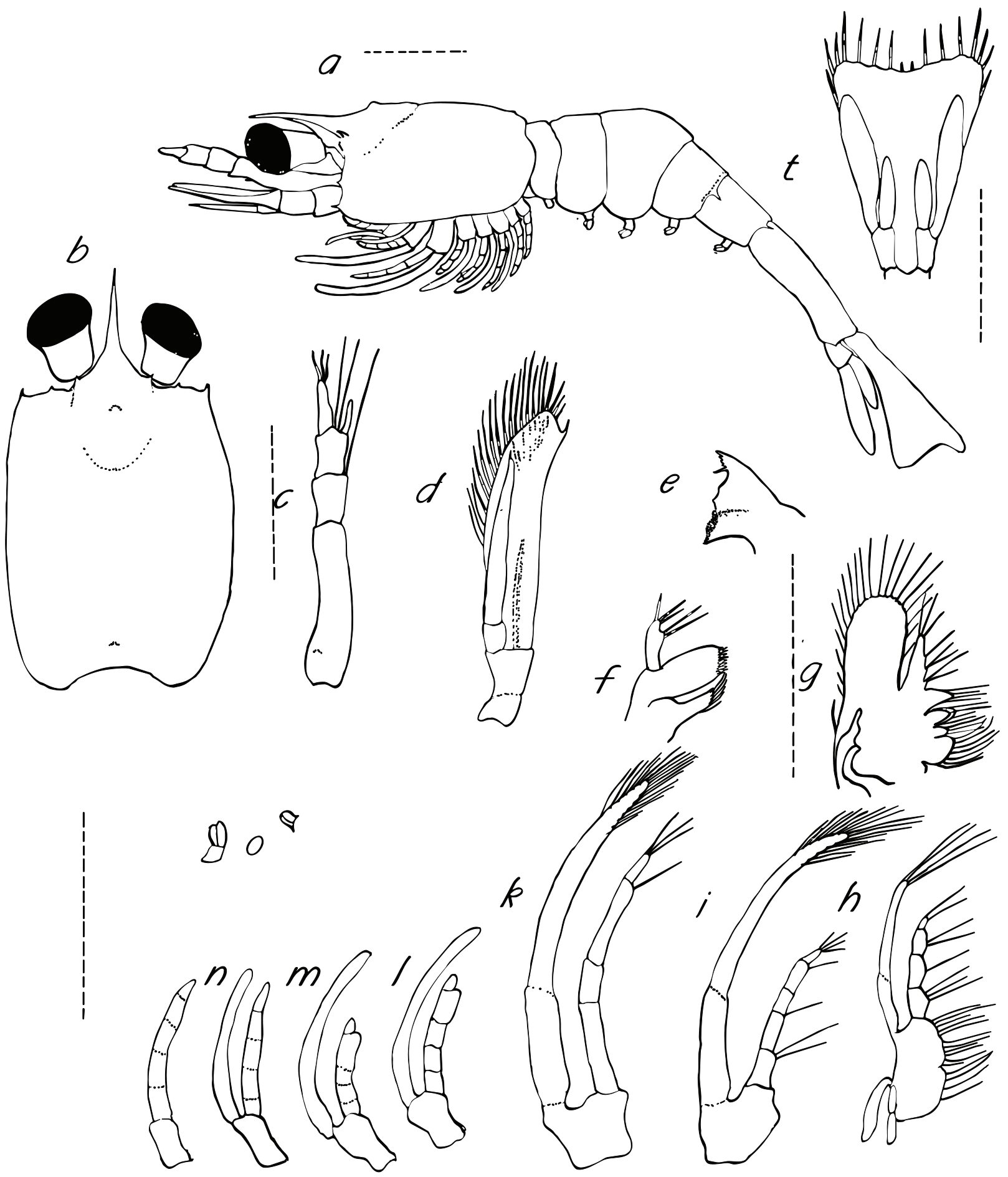

Fig. 5. Eualus fabricii, Stage III Zoea: (a) whole zoea from left side; (b) dorsal carapace; (c) antennule; (d) antenna; (e) mandible; (f) maxillule; (g) maxilla; (h) first maxilliped; (i) second maxilliped; (k) third maxilliped; (I) first pereopod; (m) second pereopod; (n) third pereopod; (o) pleopods. Broken line $=1 \mathrm{~mm}$. 
Antennule (c): rounded area and slight hump at site of future stylocerite; distal long seta on 2nd article, also two long setae near short inner flagellum; outer flagellum with three distal aesthetes.

Antenna (d): scale outer edge concave, distolateral spine about even with blade, the latter with fringe of about 20 long setae, no spine at base; flagellum shorter than scale and with short distal spine.

Mandible (e): incisor with prominent tooth at edge followed by four smaller teeth and a long denticle and two low projections on thin edge attached to molar.

Maxillule (f): proximal endite narrow and curved with distally 6 curved strong setae; distal endite wide and long with edge of rows of strong spine-like setae; endopod moderate, bifid with three distal and two lateral setae.

Maxilla (g): proximal endite unequally bilobed, with long curved setae; distal endite subequally bilobed. Endopod shorter than the anterior lobe of scaphognathite, the latter rounded distally and with about 20 long plumose setae and a short narrow posterior lobe with a terminal long spine and a retrorse seta laterally.

First maxilliped (h): endites partly fused, subequal. Endopod with 4 segments, shorter than the narrow exopod, the latter with 4 apical setae; epipod present.

Second maxilliped (i): with 5 segments, moderate in length but shorter than long exopod, the latter with 16 apical setae.

Third maxilliped ( $\mathrm{k}$ ): endopod with 5 segments, almost as long as exopod, the latter with about 16 apical setae.

Pereopods: first $(\mathrm{I})$ and second $(\mathrm{m})$ with 5 segmented endopod, the penultimate segment much wider than distal segment, simulating a primary chela. First to third with exopod; fourth (n) and fifth without exopod.

Pleopods (o): buds only but biramous, the first smaller than others.

Telson (t): with $7+7$ terminal spines, the middle pair very short, one pair lateral; endopod of uropod about half as long as exopod.

Dates of occurrence in plankton hauls: 26 June-27 August (Table 3).

Stage IV Zoea. Total length $10 \mathrm{~mm}$ (Fig. 6, 7).

Carapace (a): with anterior and posterior tubercle, supraorbital and pterygostomian spines; rostrum exceeding eye.

Abdomen: abdominal somites 4 and 5 with dorsolateral spines.

Antennule (c): with three articles, the proximal one long with small precursor of stylocerite; distal article short with short inner annulate flagellum and long setae, and larger outer conical flagellum with 4 sets of aesthetes.

Antenna (d): flagellum with 2 basal articles (one only in previous stages), exceeding scale; scale with about 25 marginal setae and strong distolateral spine about even with apex. 


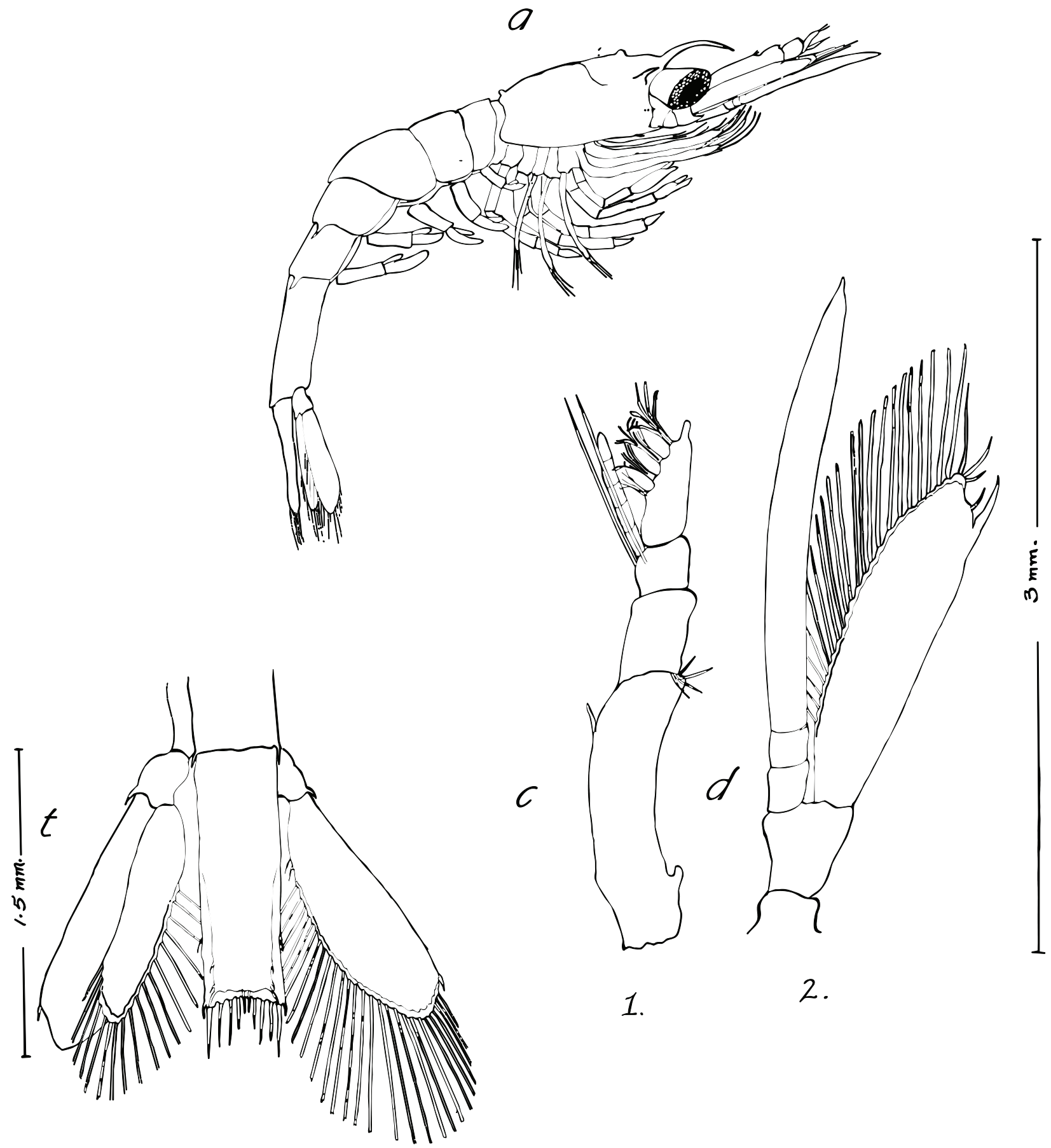

Fig. 6. Eualus fabricii, Stage IV Zoea: (a) whole zoea from right side; (c) antennule; (d) antenna; (t) telson. Scales as indicated.

Mandibles (e): tip of incisor with 2 teeth, joined to molar by thin edge with two denticles; molar strong.

Maxillule (f): proximal and distal endites about equal, the former with long plumose setae and the latter with two rows of sharp stout setae, endopod with two apical and one lateral setae. 


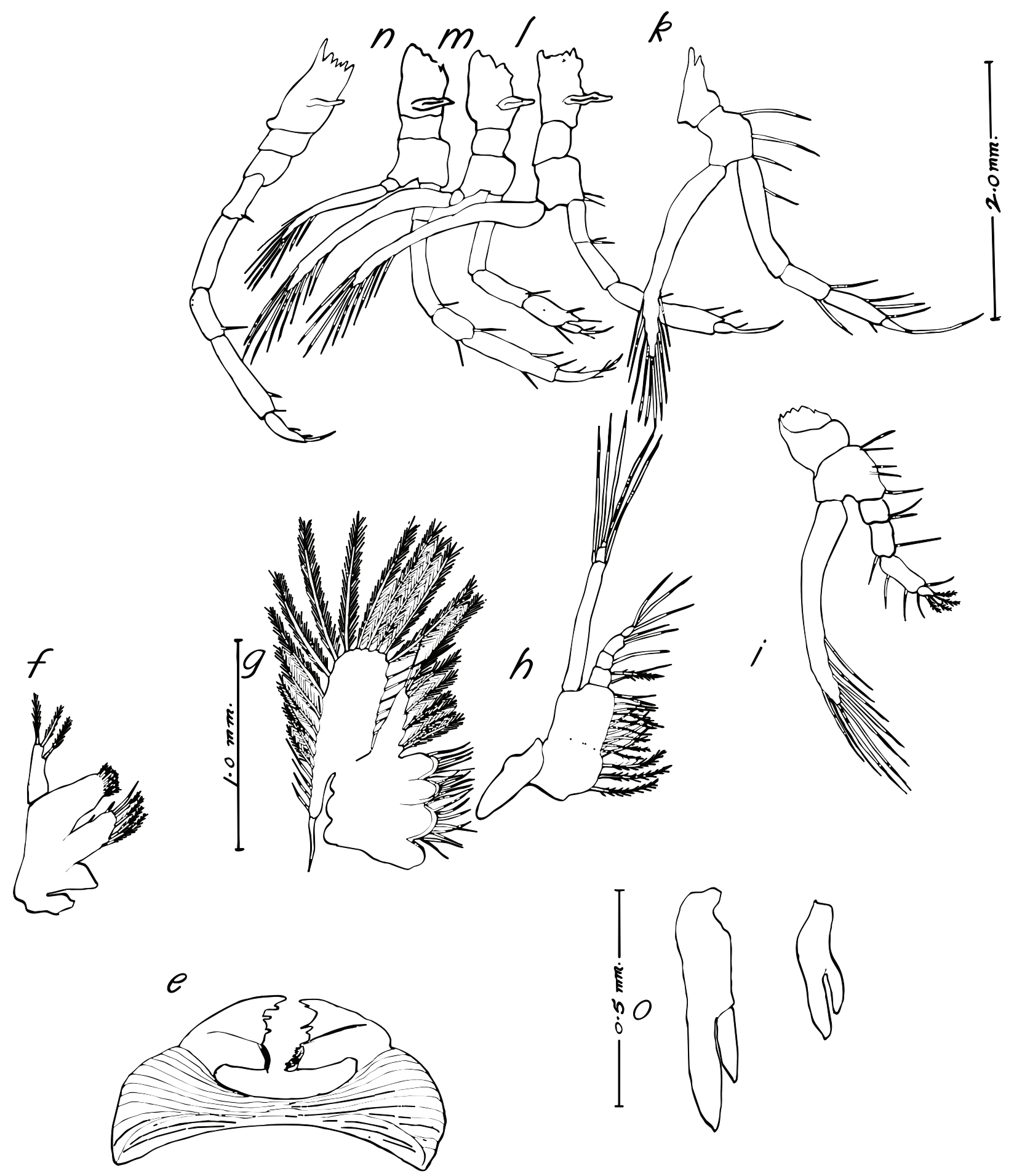

Fig. 7. Eualus fabricii, Stage IV Zoea: (e) mandibles; (f) maxillule; (g) maxilla; (h) first maxilliped; (i) second maxilliped; (k) third maxilliped; (I) first pereopod; (m) second pereopod; (n) third pereopod; (o) pleopods. Scales as indicated. 
Maxilla (g): with endites equally bilobate. Endopod shorter than anterior lobe of scaphognathite, the latter rounded and very much larger than pointed posterior lobe and with about 25 fringing plumose setae.

First maxilliped (h): with wide fused endites fringed with setae, endopod with four divisions much shorter than exopod, the latter with 5 apical setae. Epipod present.

Second maxilliped (i): endopod with four divisions, much shorter than slender exopod, the latter with about 9 apical setae.

Third maxilliped $(\mathrm{k})$ : endopod with four divisions, about as long as exopod, the latter with about 10 apical setae.

Pereopods: first (I) obscurely chelate, dactyl with long distal curved spine, exopod long with about 10 apical setae; second $(\mathrm{m})$ appearing to have early form of chela, dactyl with terminal spine, exopod long with about 9 apical setae; third $(n)$ non-chelate, dactyl sharp with distal spine, exopod short with about 8 apical setae.

Pleopods: biramous.

Telson $(\mathrm{t})$ : with sides about parallel, terminal setae $6+6$, centre ones very small, one lateral spine on posterior third. Uropods with inner branch shorter than outer.

Dates of occurrence in plankton hauls: 20-27 August (Table 3).

Stage V or VI Zoea. Total length $10 \mathrm{~mm}$ (Fig. 8, 9).

Similar to Stage IV above but with the following differences:

Antennule (c): first article with more distinct stylocerite than in Stage IV, ventromesial flagellum larger than dorsolateral and with five clumps of aesthetes.

Antenna (d): with segmented flagellum much longer than scale, the latter with fringe of about 35 setae.

Mandibles (e): incisor not clearly divided from molar but with indications that it would be in next moult.

Maxilla (g): proximal endite with one large and one small lobe, distal endite with equal lobes; proximal lobe of scaphognathite small but terminally rounded and with one long spine; fringe of setae about 25 .

Maxillipeds (h,i,k): exopods with 4, 13 and 14 apical setae in I-III, respectively.

Pereopods: first (I) and second $(\mathrm{m})$ strongly chelate, carpus of second with 5 divisions; exopods on first to third.

Pleopods (o): biramous and with appendix interna.

Telson (t): with $6+6$ terminal setae and two pairs of lateral spines.

Dates of occurrence in plankton hauls: 20 August (Table 3). 


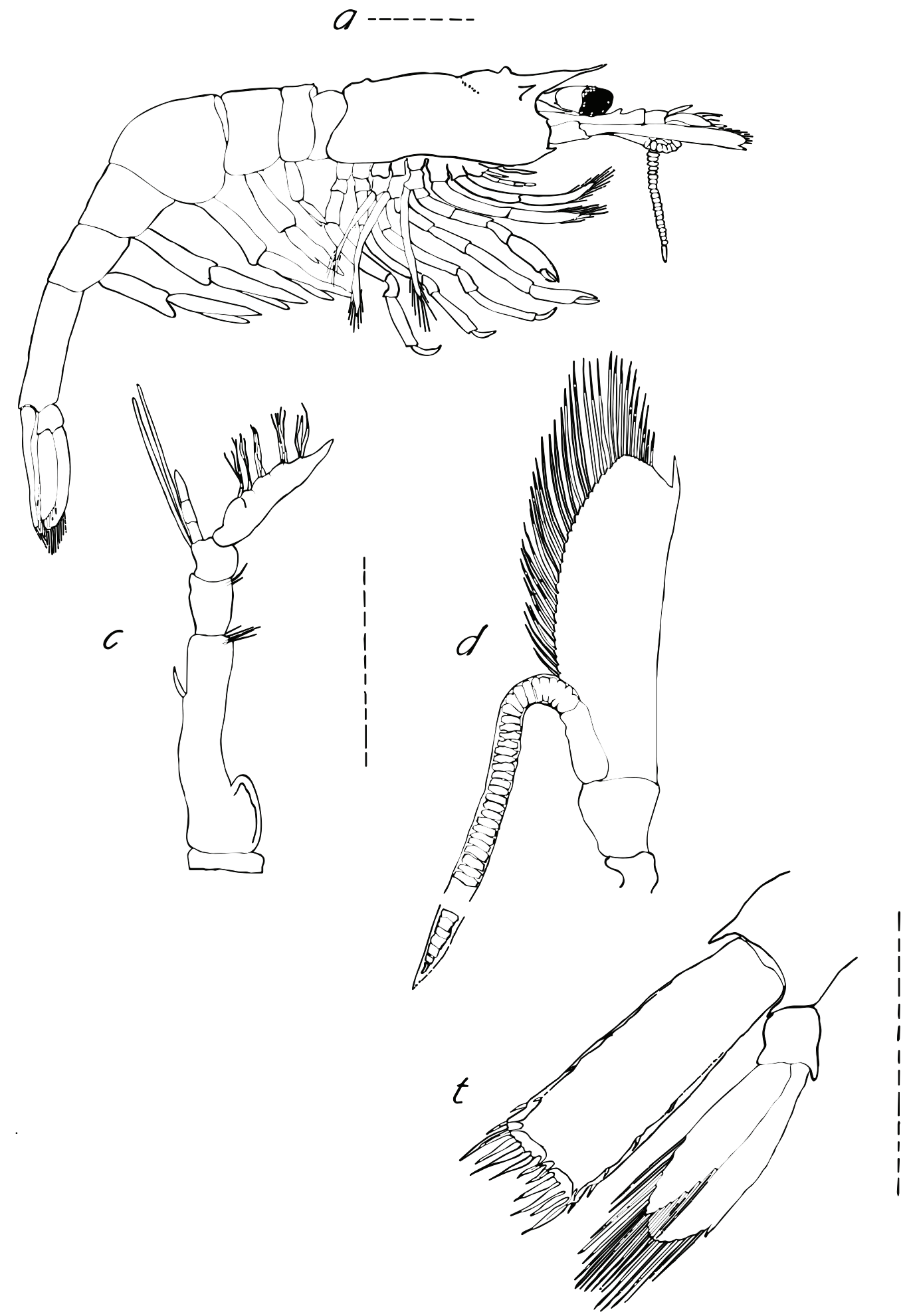

Fig. 8. Eualus fabricii, Stage V Zoea: (a) whole zoea from right side; (c) antennule; (d) antenna; (t) telson. Broken line $=1 \mathrm{~mm}$. 


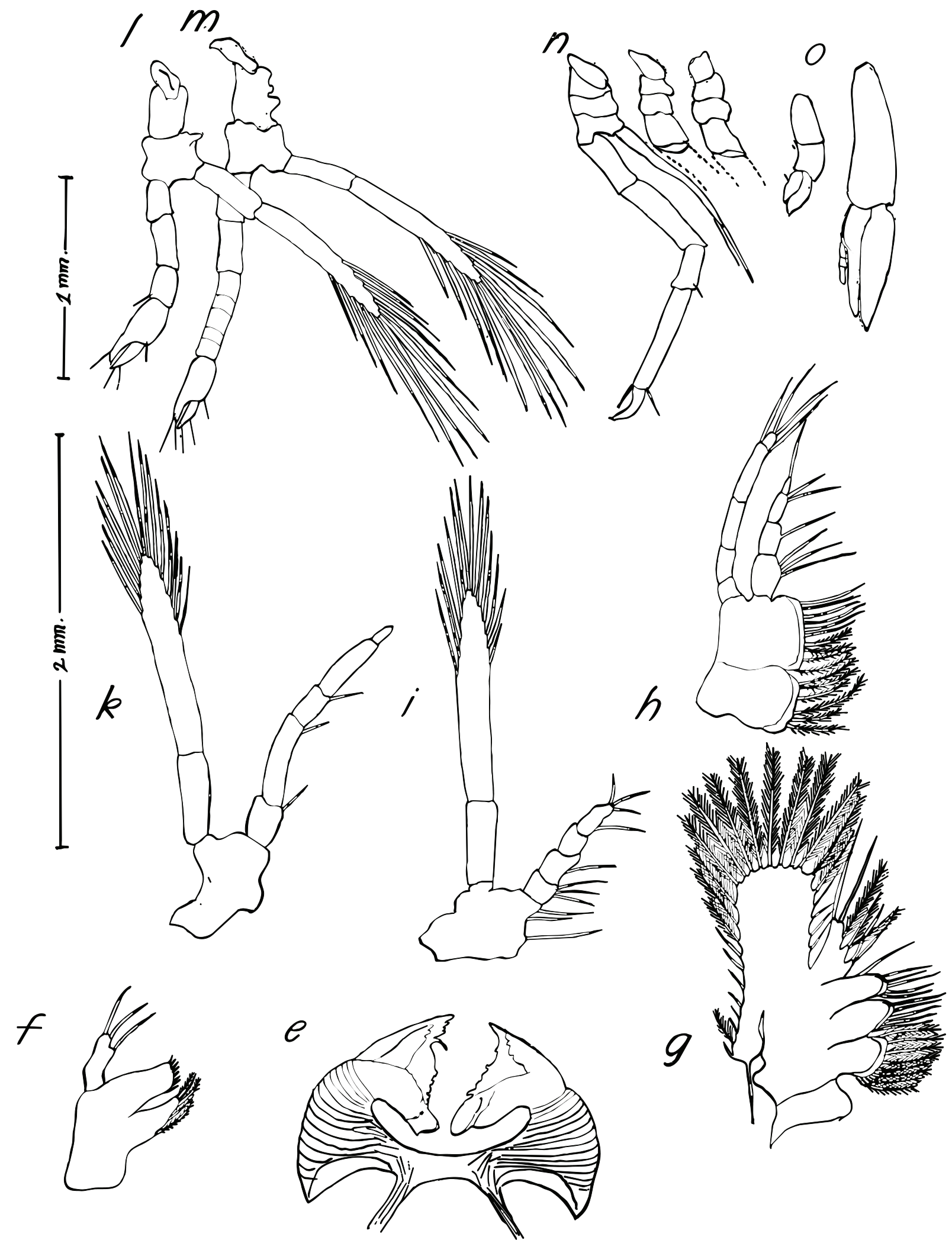

Fig. 9. Eualus fabricii, Stage V Zoea: (e) mandibles; (f) maxillule; (g) maxilla; (h) first maxilliped; (i) second maxilliped; (k) third maxilliped; (I) first pereopod; (m) second pereopod; (n) third pereopod; (o) pleopods. Scales as indicated. 
Megalopa. Total length 9.0 mm (Fig. 10, 11).

Similar to previous Stage but with the following differences:

Carapace (a): without dorsal tubercles or supraorbital spine, antennal spine clear; rostrum with two dorsal spines. Abdominal somites with no dorsolateral spines.

Antennule (c): with a pointed stylocerite reaching about half length of first article; ventromesial flagellum annulated, dilated but with fine tip; dorsolateral flagellum about as long.

Antenna (d): flagellum very much longer than scale and annulated as in adult; scale with about 35 fringing setae, dorsolateral spine about even with tip of blade.

Mandibles (e): incisor well-separated from molar.

Maxillule (f): endites unequal, the proximal thin and pointed. Endopod two-segmented.

Maxilla (g): proximal endite reduced to single setose lobe; posterior lobe of scaphognathite narrow but enlarged and fringed with about five spinous setae, total fringe about 30 setae.

First maxilliped (h): segmentation of endopod and exopod reduced.

Second maxilliped (i): distal segments of endopod shaped as in adult.

Pereopods: first $(\mathrm{I})$ and second $(\mathrm{m})$ strongly chelate, carpus of second with seven segments; first to third with reduced exopods.

Pleopods (o): biramous and with appendix interna.

Telson(t): with single pair of spines at the centre and a pair at each side terminally, and about 4 pairs of lateral spines.

Dates of occurrence in plankton hauls: 20-27 August (Table 3).

Eualus gaimardi $(\mathrm{H}$. Milne-Edwards, 1837)

Pike and Williamson, 1961: 194. fig. 2.

Haynes, 1985: 276.

The larvae of this species differ from those of E. fabricii by lacking a dorsolateral spine on the abdominal somite 4 (Table 4). In later stages there appear some minor differences in depth of telson notch and size of dorsolateral spine on abdominal somite 5. Total lengths of larvae from Ungava Bay appear larger than those quoted by Pike and Williamson (1961) for British specimens; observed lengths were 4.5 and $5.5 \mathrm{~mm}$ in Stages I and II compared with 2.9 and $3.4 \mathrm{~mm}$. Total lengths $(\mathrm{mm})$ at the different Stages were as follows: I. 4.5-4.7, II. 5.0-5.8, III. 6.8, IV. 7.5, Megalopa. 7.5 (Samples of Stage IV and Megalopa were too damaged for drawings and descriptions).

Distribution in Ungava Bay: larvae of this species were taken mostly on the east side of the bay at Koksoak River mouth, Beacon Island, Forbes Sound, near Port Burwell and Button Islands (Fig. 1; Table 1). No. of specimens taken = 92 (Table 2). 


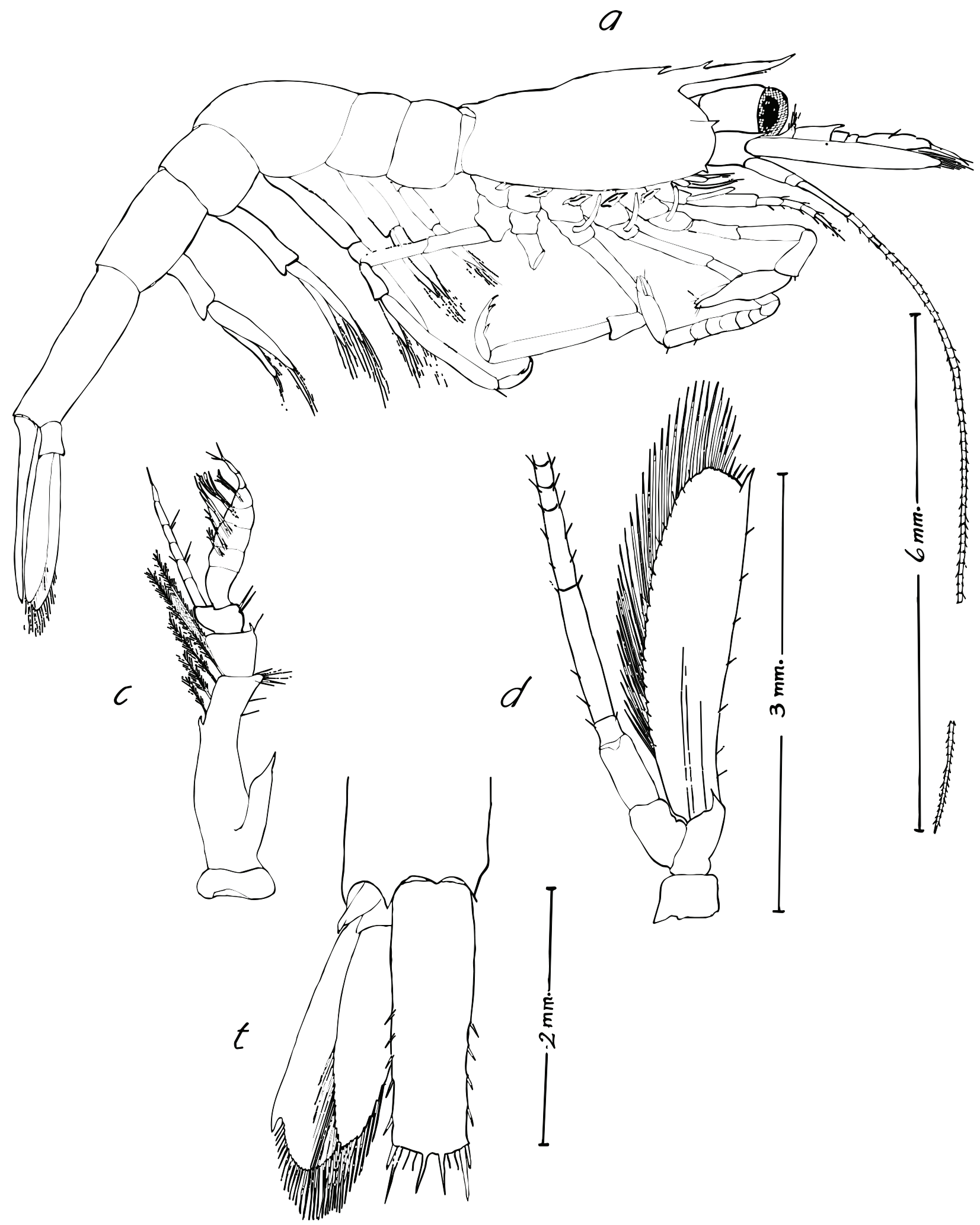

Fig. 10. Eualus fabricii, Megalopa: (a) whole animal from right side; (c) antennule; (d) antenna; (t) telson. Scales as indicated. 


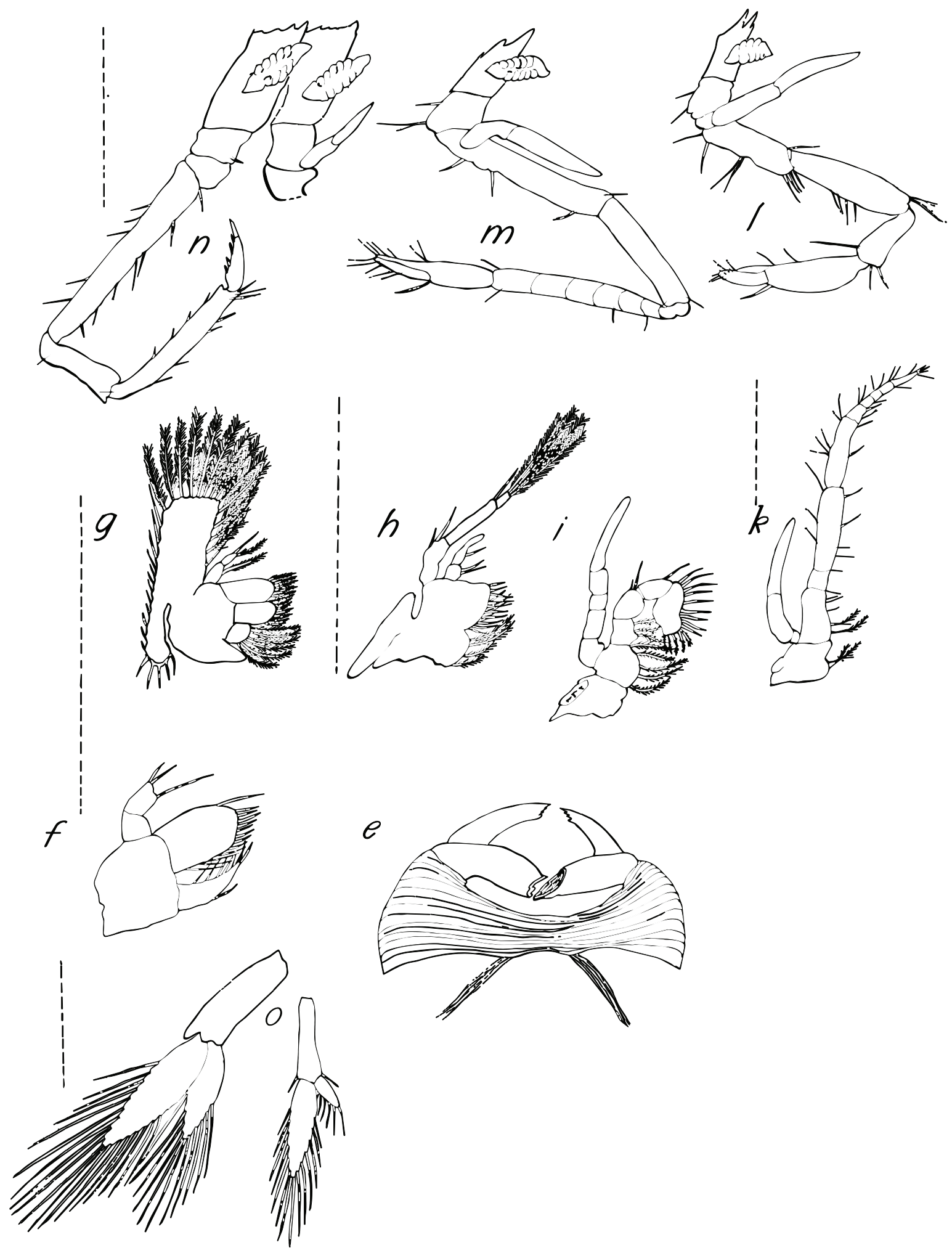

Fig. 11. Eualus fabricii, Megalopa: (e) mandibles; (f) maxillule; (g) maxilla; (h) first maxilliped; (i) second maxilliped; (k) third maxilliped; (I) first pereopod; (m) second pereopod; (n) third pereopod; (o) pleopods. Broken line $=1 \mathrm{~mm}$. 


\section{Description}

Stage I Zoea (Fig. 12, 13)

Carapace (a): with anterior and posterior dorsal tubercle; no supraorbital spine; antero-ventral spinules 3 behind pterygostomial spine. Rostrum long, reaching beyond peduncle of antennule.

Abdomen: with dorsolateral spines on somite 5 only; spines on some specimens smaller than on others.

Antennule (c): peduncle with short (obscure) distal division, conical flagellum with 4 aesthetes, a long inner plumose seta.

Antenna (d): proximal article with spine; scale with about 10 long setae, flagellum undivided about equal to scale.

Mandibles (e): incisor of right with 2 teeth and left with 4, space between it and molar with slight rise and 1 or 2 denticles.

Maxillule (f): proximal endite slightly smaller than distal endite, with long curved setae in former and 2 rows of stout spine-like setae in latter distally. Endopod with three distal and two lateral set $^{\sim u}$

First maxilliped (h): large fused endites with long fringing setae. Endopod with 4 divisions and longer exopod with 2, bearing four distal plumose setae; small bilobed epipod.

Second maxilliped (i): short endopod, exopod very long with 5 distal setae.

Third maxilliped $(k)$ : exopod longer than endopod and with 5 distal setae.

Pereopods: buds only but first (I), second $(m)$ and third $(n)$ with exopods.

No pleopod buds present.

Telson (t): with $7+7$ setae. Some specimens with deeper telson notch than others.

Dates of occurrence in plankton hauls: 29 June-14 July (Table 3).

Stage II Zoea. Total length $5.8 \mathrm{~mm}$ (Fig. 14).

Between this Stage and Stage I the differences are as follows:

The rostrum reaches only as far as the distal end of the 2 nd article of the antennule.

Antennule (c): antennular peduncle has three articles; the inner flagellum is short and conical with a couple of apical and an adjacent setae, and the outer, cylindrical with an apical aesthete and 2 setae, more than twice as long as the inner.

Antenna (d): antennal scale has a strong distolateral spine, about even with the tip of the blade which appears to have a single segment. The number of fringing setae has increased to about 16. 


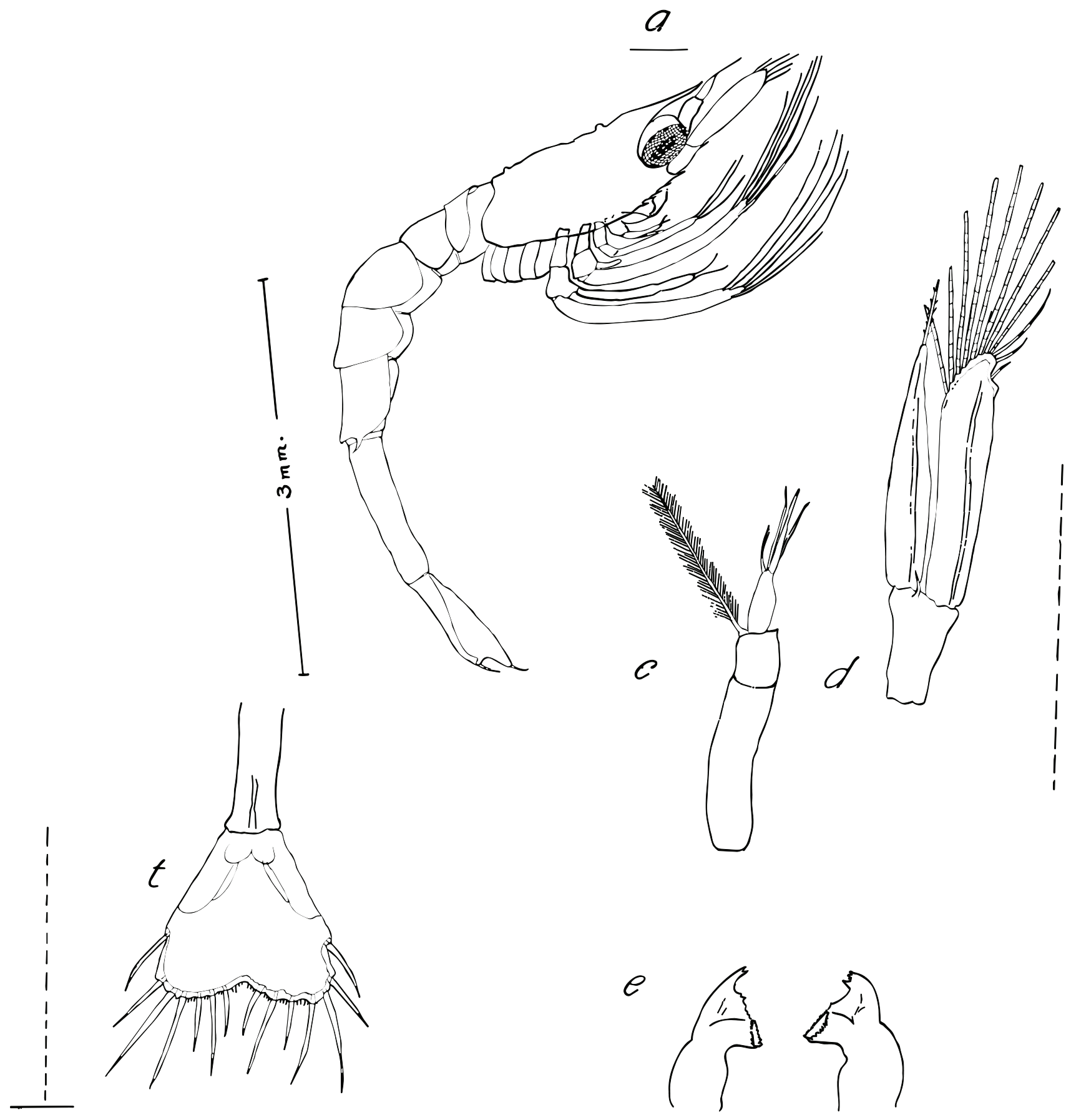

Fig. 12. Eualus gaimardi, Stage I Zoea: (a) whole zoea from right side; (c) antennule; (d) antenna; (e) mandibles; (t) telson. Scale as indicated; broken line $=1 \mathrm{~mm}$.

Maxilla (g): exopod (scaphognathite) has a fringe of about 10 setae and a narrow posterior lobe with terminal seta.

Pereopods $(I, m, n)$ : show a few divisions and preliminary modification of propodus and dactyl to form chelae in first and second pereopods. 


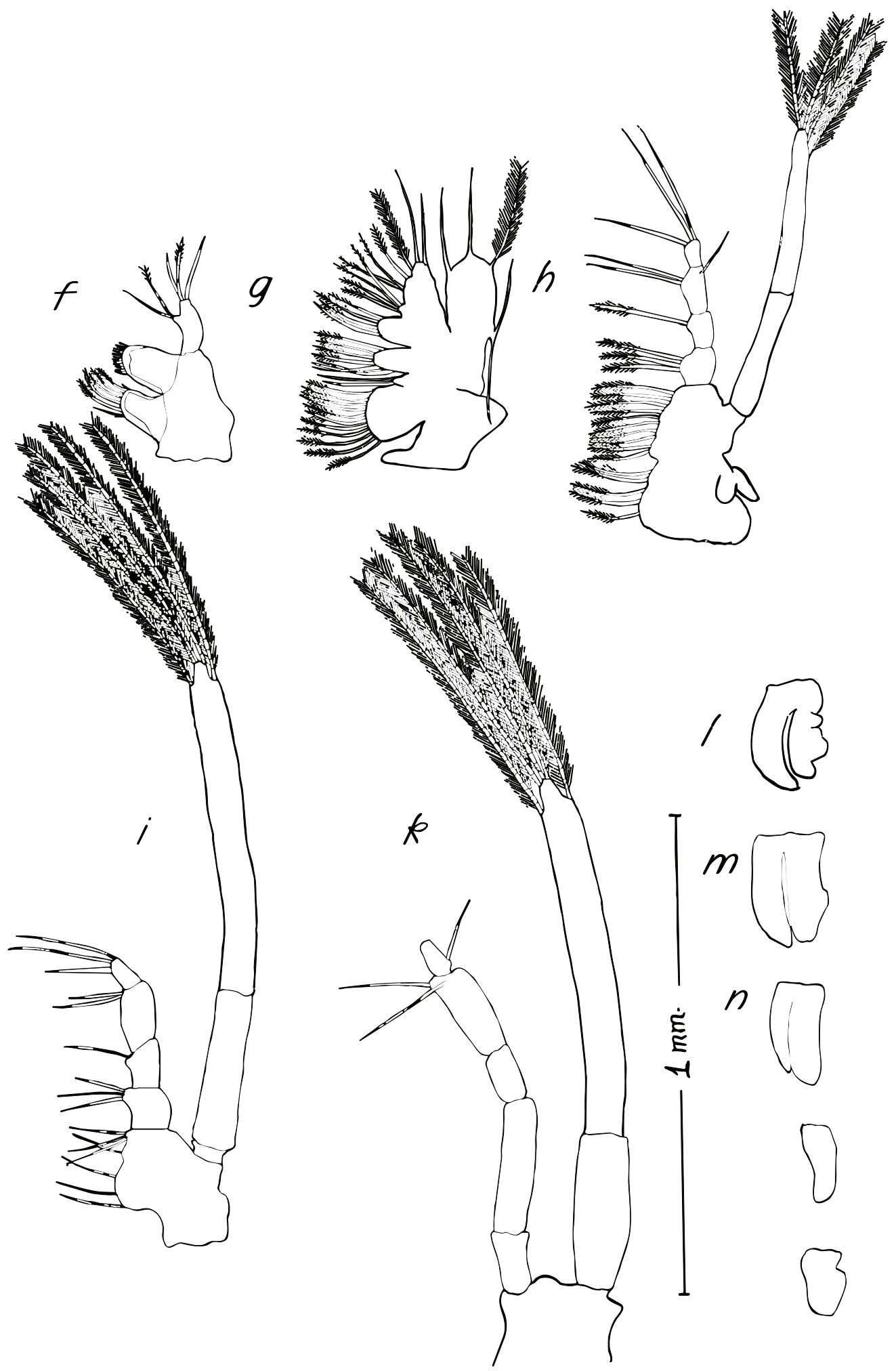

Fig. 13. Eualus gaimardi, Stage I Zoea: (f) maxillule; (g) maxilla; (h) first maxilliped; (i) second maxilliped; (k) third maxilliped; (I) first pereopod; (m) second pereopod; (n) third pereopod. Scale as indicated. 


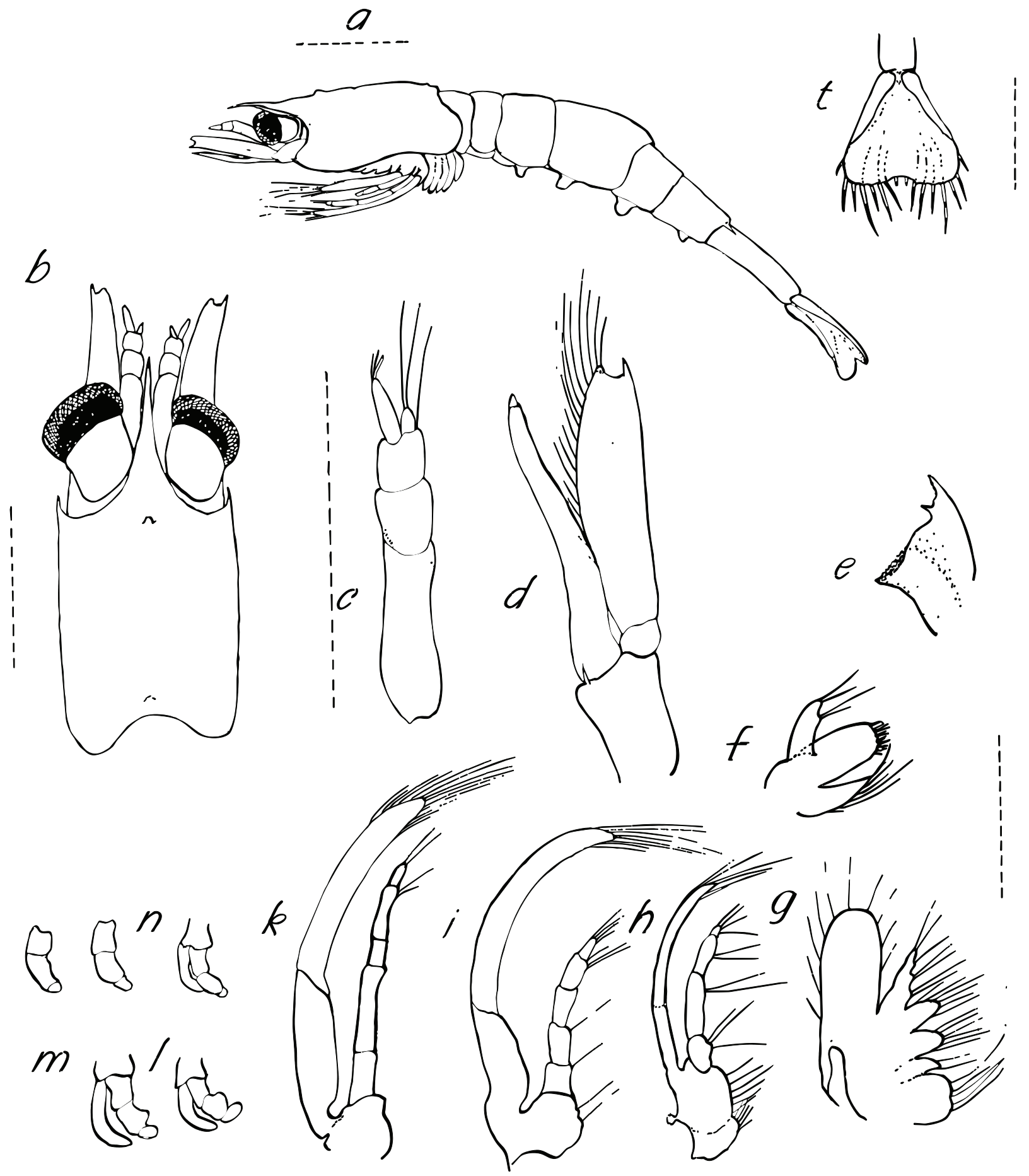

Fig. 14. Eualus gaimardi, Stage II Zoea: (a) whole zoea from left side; (b) dorsal carapace; (c) antennule; (d) antenna; (e) mandible; (f) maxillule; (g) maxilla; (h) first maxilliped; (i) second maxilliped; (k) third maxilliped; (I) first pereopod; $(\mathbf{m})$ second pereopod; $(\mathbf{n})$ third pereopod; $(\mathbf{t})$ telson. Broken line $=1 \mathrm{~mm}$. 
Pleopods: form buds.

Telson $(\mathrm{t})$ : has $8+8$ setae, the centre pair very short.

Dates of occurrence in plankton hauls: 26 June-7 July (Table 3).

Stage III Zoea. Total length 8.0 mm (Fig. 15).

Carapace (a): with anterior and posterior small median tubercles, supraorbital and pterygostomial spines; faint indication of cervical groove. Rostrum styliform, long, exceeding eyes.

Abdomen: abdominal somites with dorsolateral spine on somite 5 only.

Antennule (c): first article without indication of stylocerite, ventral strong spine on distal third of first article; outer flagellum with indistinct annulations and three groups of aesthetes, inner short and slender with apical seta and adjacent long seta.

Antenna $(d)$ : scale with distolateral spine about even with blade and fringe of about 20 setae; flagellum about three-quarters length of scale.

Mandible (e): incisor with sharp tooth followed by 2 small blunt teeth and a long denticle, also 2 low projections on even edge to strong molar.

Maxillule (f): proximal endite tapered with 6 strong apical setae, slightly shorter than distal endite, the latter with 2 rows of strong spine-like setae apically; endopod short, bifid with 3 and 2 setae on branches.

Maxilla (g): proximal endite obscurely bilobed, rounded, about even with subequally bilobed distal endite; endopod shorter than anterior lobe of scaphognathite, the latter rounded apically and with fringe of about 20 setae, posterior lobe narrow and short with terminal long spine.

First maxilliped (h): proximal endite shorter than and fused with distal. Endopod 4-segmented, shorter than slender exopod, the latter with 4 apical setae; epipod present.

Second maxilliped (i): endopod 5-segmented, much shorter than stout exopod, the latter with about 12 apical setae.

Third maxilliped $(k)$ : endopod 5-segmented almost as long as stout exopod, the latter with about 14 apical setae.

Pereopods: first (I), second $(m)$ and third $(n)$ obscurely segmented endopods with exopods; fourth and fifth without exopods, shorter than third.

Pleopods (o): buds only but biramous.

Telson (t): elongate but subtriangular, terminal setae $7+7$, central pair very small.

Dates of occurrence in plankton hauls: 14 July-26 August (Table 3). 


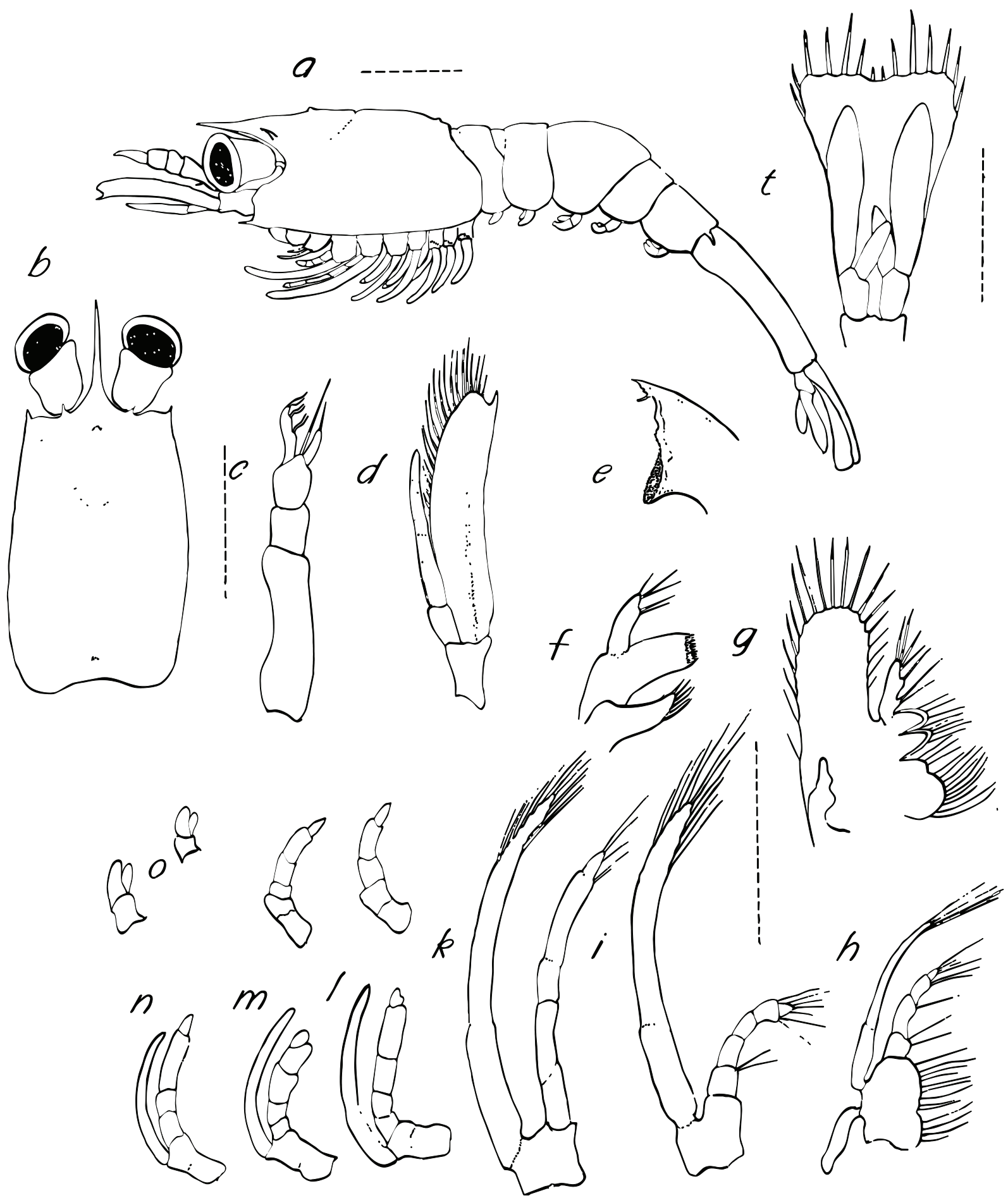

Fig. 15. Eualus gaimardi, Stage III Zoea: (a) whole zoea from left side; (b) dorsal carapace; (c) antennule; (d) antenna; (e) mandible; (f) maxillule; (g) maxilla; (h) first maxilliped; (i) second maxilliped; (k) third maxilliped; (I) first pereopod; (m) second pereopod; $(\mathbf{n})$ third pereopod; (o) pleopods; (t) telson. Broken line $=1 \mathrm{~mm}$. 


\section{Eualus macilentus}

and

\section{Eualis pusiolus}

No samples of larvae were obtained in these surveys, so no representative specimens were available for detailed descriptions. Table 5 summarizes the characteristics of larvae from published sources.

\section{Genus Lebbeus White, 1847}

Haynes, 1985: 278

The species in this genus have no exopods on any of the pereopods. Dorsolateral spines are on abdominal somites 4 and 5 .

Lebbeus groenlandicus (J. C. Fabricius, 1775)

Haynes, 1978: 457-465, fig. 1-3.

These have the largest larvae among species of Hippolytidae in Ungava Bay. The telson with setae $11+11$ are found in Stages I and II (Table 6). Total lengths $(\mathrm{mm})$ at the different Stages: I. 7.8-8.0, II. 8.0-10.8, Megalopa. 8-11.

Distribution in Ungava Bay: Imilik, Hopes Advance Bay, Inuksulik (1), Leaf Bay, Koksoak River mouth, Beacon Island, Keglo Bay, Adlorilik, near Port Burwell and Button Islands (Fig. 1; Table 1). No. of specimens taken $=857$ (Table 2).

\section{Description}

Stage I Zoea. Total length $8.0 \mathrm{~mm}$ (Fig. 16, 17).

Carapace (a): with large and immobile eyes. Anterior and posterior median tubercle, no supraorbital spine, three anteroventral spinules behind pterygostomian spine. Rostrum wide at base and long, exceeding antennular peduncle.

Abdomen: with dorsolateral spines on somites 4 and 5.

Antennule (c): peduncle stout, one-segmented, a short distal inner projection with long plumose seta; outer flagellum short, sub-conical, with distal slender section and 4 aesthetes.

Antenna (d): scale segmented at tip and with about 10 long setae, distolateral spine about even with tip; flagellum about one-third longer than scale.

Mandibles (e): right incisor with 4 teeth, left with 2, separated from molar by thin edge with a few denticles.

Maxillule (f): proximal endite larger than distal. Endopod narrow with 3 distal plumose setae and 2 lateral plumose setae.

Maxilla (g): proximal endite with large lobe with about 15 curved long plumose setae and a small pointed lobe with about 3 setae; distal endite subequally bilobed. Endopod with about 6 plumose setae, shorter than anterior lobe of scaphognathite, the latter fringed with about 35 plumose setae, posterior lobe small and pointed with one long seta at its tip. 


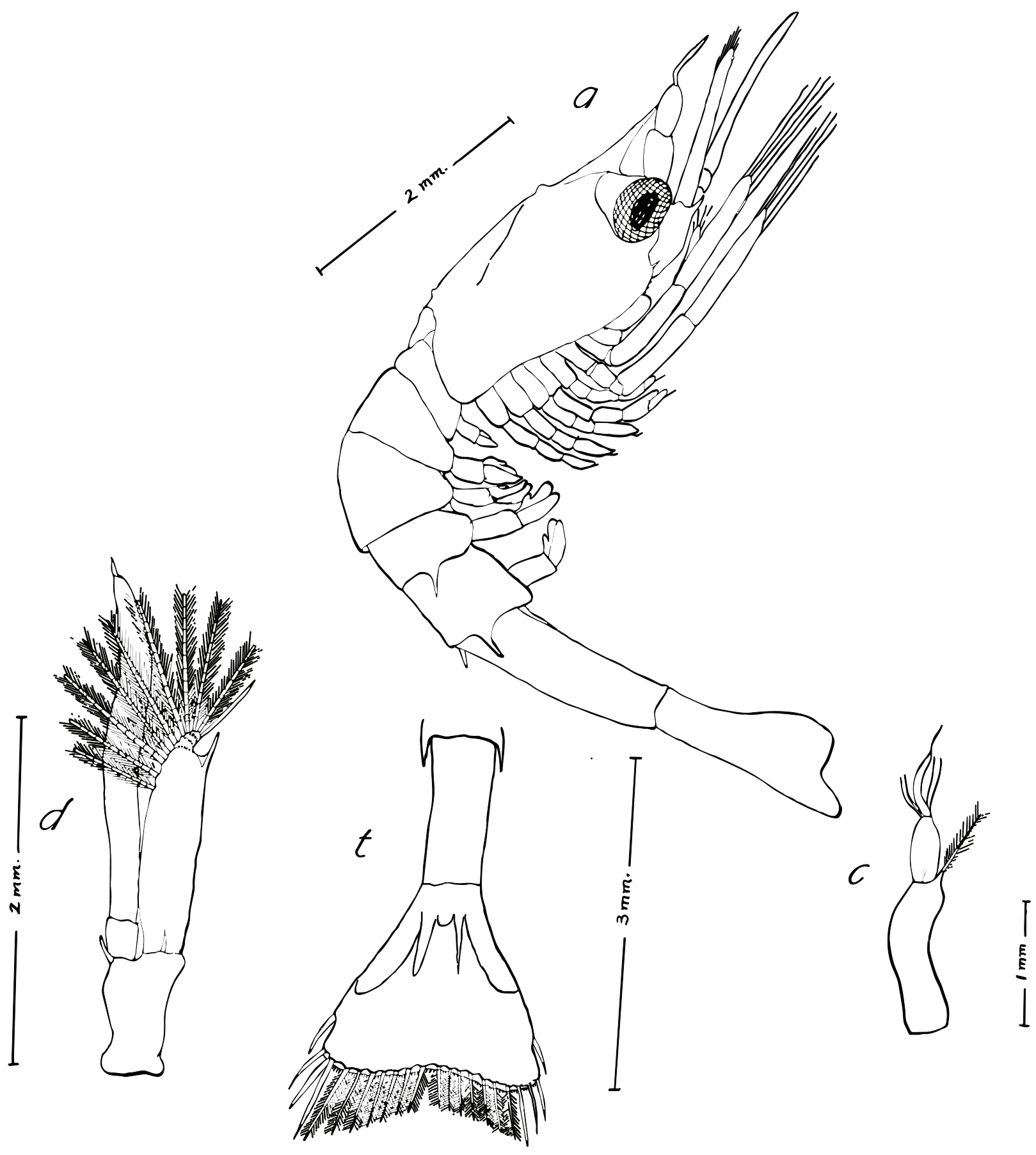

Fig. 16. Lebbeus groenlandicus, Stage I Zoea: (a) whole zoea from right side; (c) antennule; (d) antenna; (t) telson. Scales as indicated. 

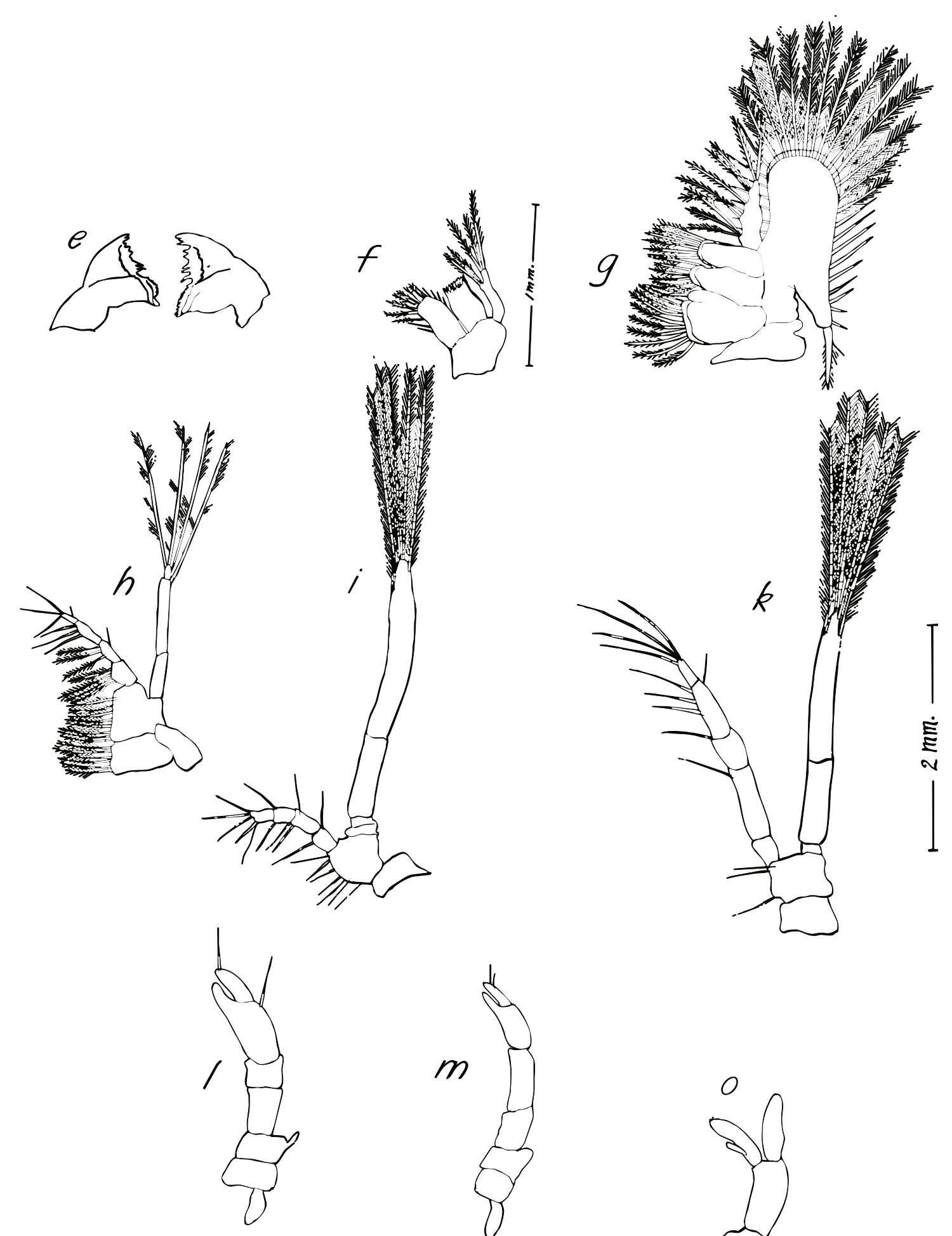

Fig. 17. Lebbeus groenlandicus, Stage I Zoea: (e) mandibles; (f) maxillule; (g) maxilla; (h) first maxilliped; (i) second maxilliped; (k) third maxilliped; (I) first pereopod; (m) second pereopod; (o) pleopod. Scales as indicated. 
First maxilliped (h): proximal and distal endites fused with many long plumose setae at inner edge, endopod with 4 divisions shorter than exopod, the latter with 4 long apical setae. Epipod present.

Second maxilliped (i): endopod with 4 divisions very much shorter than exopod, the latter with 5 apical setae.

Third maxilliped $(\mathrm{k})$ : endopod with 5 divisions almost as long as exopod which has 5 apical setae.

Pereopods: first $(\mathrm{I})$ and second $(\mathrm{m})$ distinctly chelate, carpus of second not annulate. No exopods.

Pleopods (o): biramous, appendix interna present.

Telson $(\mathrm{t})$ : with $11+11$ terminal setae.

Dates of occurrence in plankton hauls: 26 June -7 July (Table 3).

Stage II Zoea. Total length $9.0 \mathrm{~mm}$ (Fig. 18).

Differences from Stage I are as follows:

Carapace (a): has a supraorbital and antennal spine as well as a pterygostomial spine; no spinules behind pterygostomial spine; posterior median tubercle very small.

Antennule (c): peduncle with 3 articles, proximal with small pointed stylocerite and inner distal spine. Flagella both faintly segmented, the outer with about 7 lateral groups of aesthetes, the inner slender and shorter with long adjacent setae.

Antenna (d): fringing setae number about 25 on scale, with faint small segment at tip of blade; peduncle with 3 segments.

Mandible (e): incisor followed by about 7 small equal spines on thin edge between it and molar, also 4 long denticles near molar.

Maxilla $(\mathrm{g})$ : posterior lobe of scaphognathite extended, narrow, with 3 terminal long spinous setae; 35 setae on anterior lobe. Setation on endopod different from Stage I.

First maxilliped (h): epipod bilobed, exopod with 4 apical setae.

Second maxilliped (i): small epipod present; about 9 apical setae on exopod.

Third maxilliped (k): about 12 apical setae on exopod.

Dates of occurrence in plankton hauls: 24 June-25 August (Table 3).

Megalopa. Total length $11.0 \mathrm{~mm}$ (Fig. 19, 20).

Carapace (a): with two median spines behind rostrum, strong supraorbital spine. Rostrum short, robust, not as long as eye.

Abdomen: with pointed pleura bearing few short setae. 


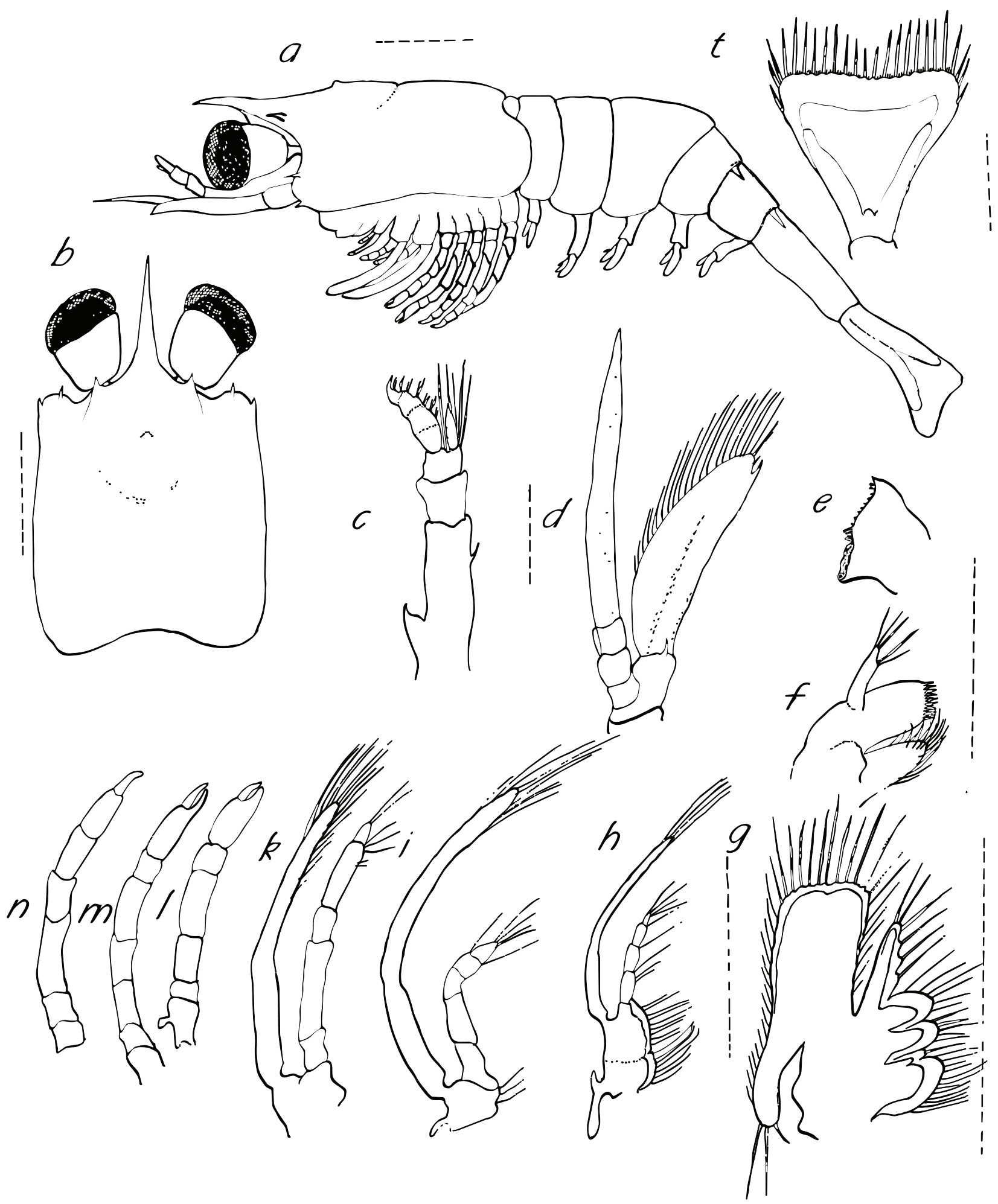

Fig. 18. Lebbeus groenlandicus, Stage II Zoea: (a) whole zoea from left side; (b) dorsal carapace; (c) antennule; (d) antenna; (e) mandible; (f) maxillule; (g) maxilla; (h) first maxilliped; (i) second maxilliped; (k) third maxilliped; (I) first pereopod; (m) second pereopod; $(\mathbf{n})$ third pereopod; $(\mathbf{t})$ telson. Broken line $=1 \mathrm{~mm}$. 


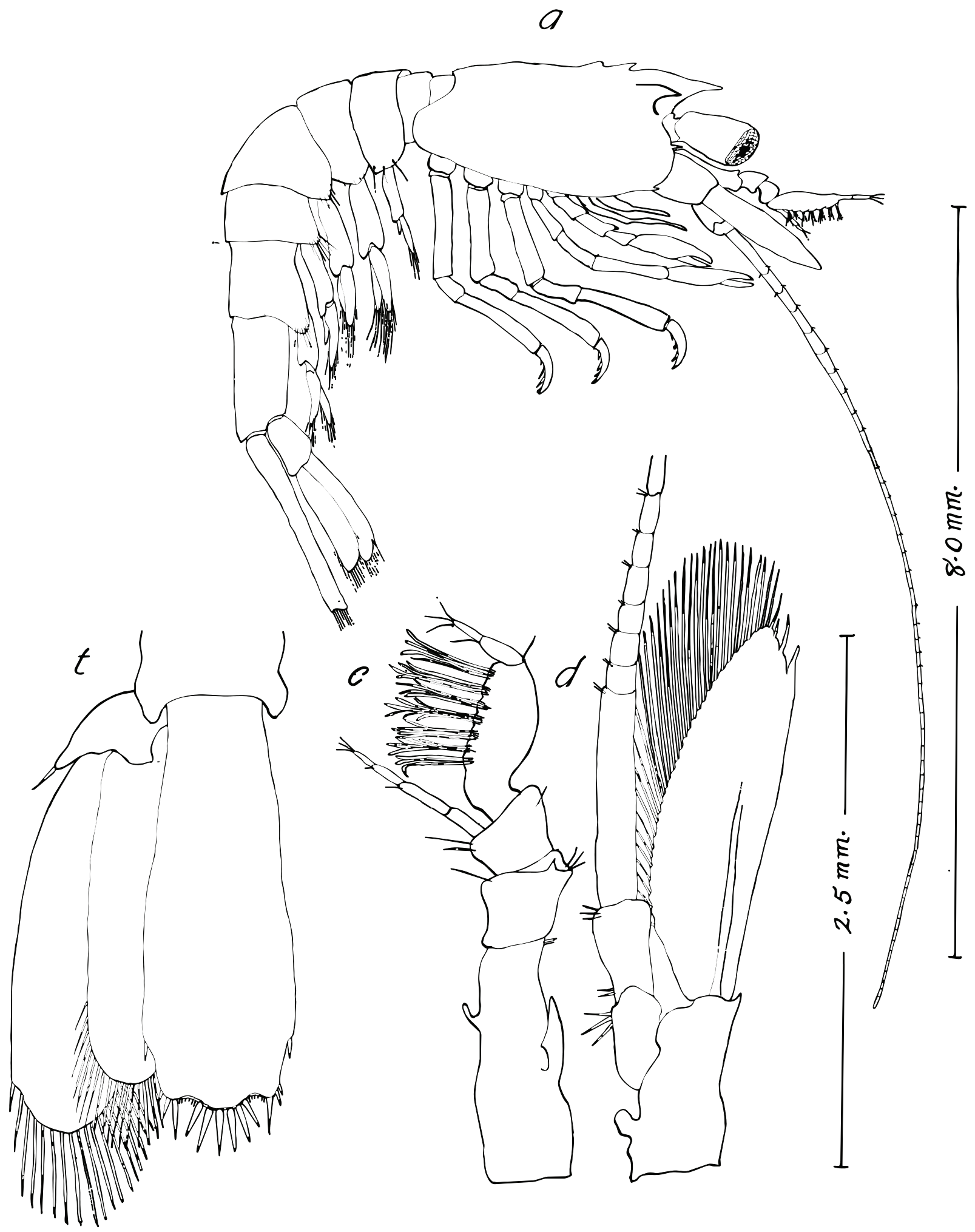

Fig. 19. Lebbeus groenlandicus, Megalopa: (a) whole animal from right side; (c) antennule; (d) antenna; (t) telson. Scales as indicated. 

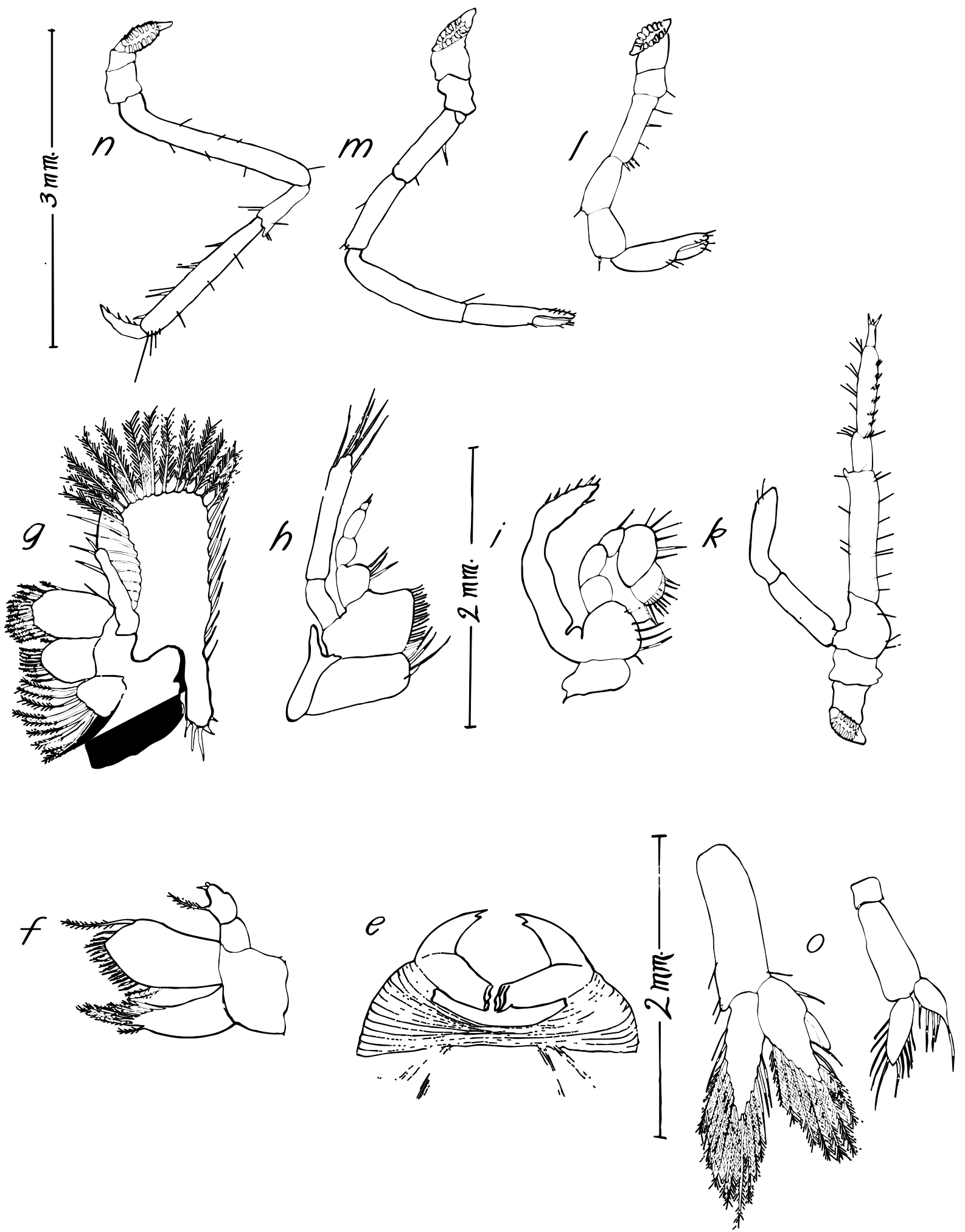

Fig. 20. Lebbeus groenlandicus, Megalopa: (e) mandibles; (f) maxillule; (g) maxilla; (h) first maxilliped; (i) second maxilliped; (k) third maxilliped; (I) first pereopod; (m) second pereopod; (n) third pereopod; (o) pleopods. Scales as indicated. 
Antennule (c): first article longer than other two and with pointed stylocerite and median spine; spine on middle article; thick portion of outer flagellum with 7 groups of aesthetes and short slender terminal portion with two divisions bearing setae; inner flagellum slender with 4 divisions.

Antenna (d): scale with fringe of about 35 long setae and distolateral spine exceeded by blade; flagellum longer than body.

Mandibles (e): incisor with two teeth, well-separated from stout molar.

Maxillule (f): proximal endite narrow and pointed, smaller than expanded distal endite. Endopod short, 2-segmented, with two terminal and one lateral setae.

Maxilla (g): proximal endite now unilobate and somewhat reduced, with long curved setae; distal endite unequally bilobed. Endopod small; anterior lobe of scaphognathite subrectilinear with fringe of about 30 setae, posterior lobe narrow and short with 5 terminal spinous setae.

First maxilliped (h): endites fused, wide, the proximal sparingly setose on inner edge. Endopod with 4 divisions the distal small and proximally expanded. Exopod longer than endopod and with 5 apical setae. Bilobed epipod present.

Second maxilliped (i): endopod shaped as in adult, distal segment wider than long. Exopod about as long as endopod, terminally expanded but pointed.

Third maxilliped (k): endopod leglike, large with 5 divisions; exopod about half as long, terminally expanded.

Pereopods: first (I) and second (m) strongly chelate, carpus of second without divisions.

Pleopods (o): well-developed, appendix interna on 2-5.

Telson ( $\mathrm{t}$ ): sides almost parallel, terminally with fan of 6 central setae and 3 lateral setae, and a subterminal spine on each side.

Dates of occurrence in plankton hauls: 10-20 August (Table 3).

Lebbeus polaris (Sabine, 1821)

Haynes, 1981: 422-426, fig. 1, 2; 1985: 278.

Zoeal Stages I and II are somewhat similar to L. groenlandicus but smaller: 6.5 and $8.1 \mathrm{~mm}$, respectively, compared with 7.9 and $9.5 \mathrm{~mm}$. Also the number of telson setae are fewer: $9+9$ compared with $11+11$ (Table 6; Haynes, 1978, 1981 and 1985). The average total length of Stages III, IV and Megalopa were 8.4, 8.5 and $8.7 \mathrm{~mm}$, respectively.

Distribution in Ungava Bay: although this was the most abundant adult taken in Ungava Bay (Squires, 1957), only a few larvae were taken in the present collection. Larvae were taken mostly on the east side of the bay at Inuksulik (1), west of Adlorilik, Adlorilik, Forbes Sound, near Port Burwell and Button Islands (Fig. 1; Table 1). No. of specimens taken = 28 (Table 2).

\section{Description}

Stage I Zoea. The specimens were damaged and could not be used for drawings or description. 
Stage II Zoea. Total length $8.3 \mathrm{~mm}$ (Fig. 21).

Carapace (a): with supraorbital and pterygostomial spines, anterior and posterior median tubercles. Rostrum short, (scarcely reaching cornea of eye) styliform, descending.

Abdomen: with dorsolateral spine on abdominal somites 4 and 5 .

Antennule (c): stylocerite is a small curved projection on proximal 4th of first article; 2nd article with distal spine; outer flagellum with 6 groups of aesthetes, inner flagellum about half as long as outer.

Antenna (d): scale with distolateral spine about even with tip of blade, setal fringe about 35; flagellum almost twice as long as scale, faintly annulated.

Mandible (e): left with sharp outer tooth and accessory followed by long denticle, a space with one low tooth and two long denticles and large rough molar.

Maxillule (f): proximal endite small, narrow and curved with about 5 strong apical setae; distal endite wide, long, with apical rows of spine-like setae. Endopod short, robust, bifid, with 2 distal and 1 lateral seta.

Maxilla (g): proximal endite with one small and one large lobe, distal endite subequally bilobed, rounded; endopod shorter than anterior lobe of scaphognathite, the latter subrectilinear, skewed inward distally and with fringe of about 25 setae, posterior lobe very narrow with long terminal seta.

First maxilliped (h): proximal endite shorter than distal, the latter partially fused with 4-segmented endopod. Exopod long, slender, with four apical setae. Epipod present.

Second maxilliped (i): endopod 5-segmented, about half as long as exopod, the latter with about 10 apical setae.

Third maxilliped (k): endopod almost as long as exopod which has about 12 apical setae.

Pereopods: first (I) stout and strongly chelate; second $(\mathrm{m})$ more slender than the first, chela slender, carpus with about 3 faint annulations; third and fourth slender, about as long as second but non-chelate. No exopods present.

Pleopods: first (o) small with very short endopod. Second (p) much larger than the first, endopod with appendix interna. The third to fifth are similar to the second.

Telson $(\mathrm{t})$ : with $8+8$ terminal setae and a pair of lateral spines.

Dates of occurrence in plankton hauls: 14 July-26 August (Table 3).

Stage III Zoea. Total length 8.0 mm (Fig. 22).

Carapace (a): with anterior tubercle, and supraorbital, antennal and pterygostomial spines (all spines very small); a faint cervical groove. Rostrum styliform, short, scarcely reaching the edge of the cornea; a faint ridge dorsally.

Abdomen: with dorsolateral spines on somites 4 and 5; shape of pleura beginning to resemble adult.

Antennule (c): first article with small beginning of stylocerite, a sharp outer spine on distal second article; dilated outer flagellum showing segmentation, inner not so and short. 


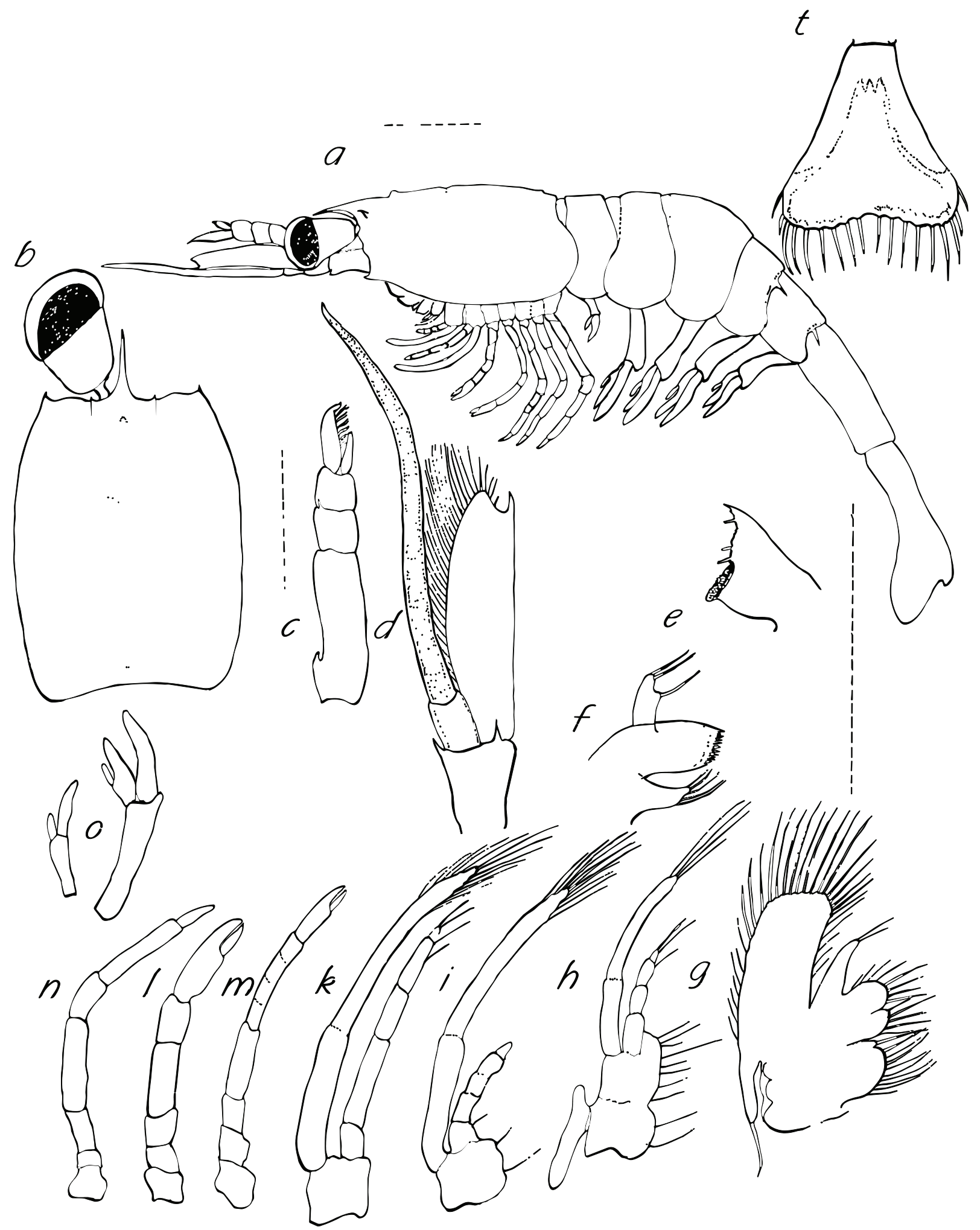

Fig. 21. Lebbeus polaris, Stage II Zoea: (a) whole zoea from left side; (b) dorsal carapace; (c) antennule; (d) antenna; (e) mandible; (f) maxillule; (g) maxilla; (h) first maxilliped; (i) second maxilliped; (k) third maxilliped; (I) first pereopod; (m) second pereopod; (n) third pereopod; (o) pleopod; (t) telson. Broken line $=1 \mathrm{~mm}$. 


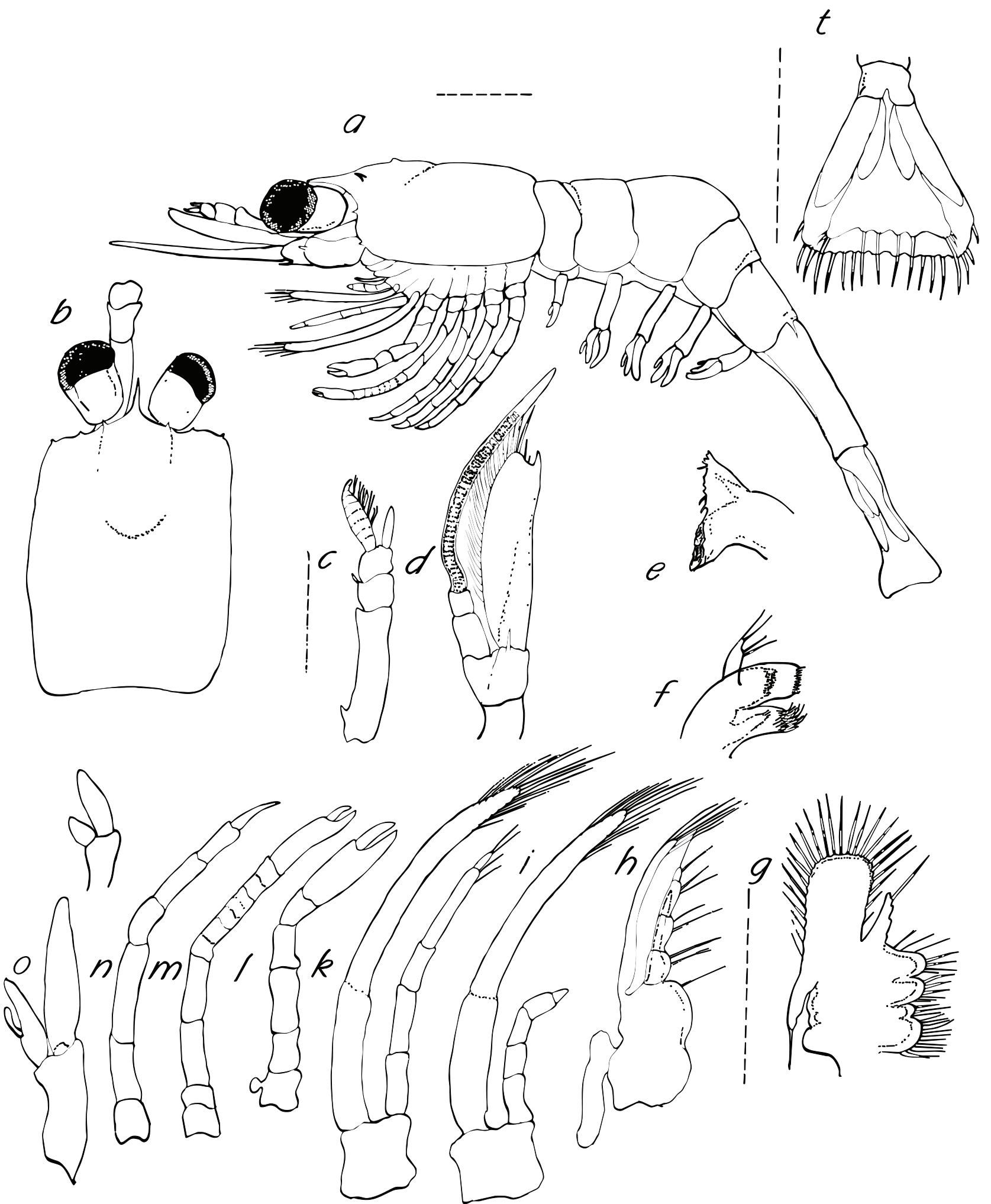

Fig. 22. Lebbeus polaris, Stage III Zoea: (a) whole zoea from left side; (c) antennule; (d) antenna; (e) mandible; (f) maxillule; (g) maxilla; (h) first maxilliped; (i) second maxilliped; (k) third maxilliped; (I) first pereopod; (m) second pereopod; $(\mathbf{n})$ third pereopod; (o) pleopods; $(\mathbf{t})$ telson. Broken line $=1 \mathrm{~mm}$. 
Antenna (d): distolateral spine about even with blade of scale, numerous fringing setae; flagellum longer than scale, showing primary segmentation.

Mandible (e): incisor almost even with molar, with 4 teeth plus denticle and about 3 spines and 2 denticles between it and molar, the latter large with spooned tip.

Maxillule (f): endopod short with 2 apical and 2 lateral setae; endites subequal in length, the proximal slightly more slender.

Maxilla (g): proximal endite unequally bilobed about even with subequal lobes of distal endite. Endopod about half as long as anterior lobe of scaphognathite, the latter sloped inward at distal corner and with about 25 fringing setae; posterior lobe very narrow and with terminal long spine.

First maxilliped (h): endites subequal, partially fused. Endopod with 4 divisions, almost as long as narrow exopod which has 6 apical setae; epipod long, unequally bilobed.

Second maxilliped (i): endopod with 5 divisions, distal small, much shorter than long exopod which has 13 apical setae.

Third maxilliped $(k)$ : endopod with 5 divisions, almost as long as long exopod which has 15 apical setae.

Pereopods: first (I) strongly chelate, with a very small epipod; second $(\mathrm{m})$ chelate, carpus with about 7 divisions, some not clear; third to fifth similar with pointed dactyl.

Pleopods: biramous, first (o) with endopod about half as long as exopod, second ( $p$ ) with endopod shorter than exopod and with appendix interna.

Telson (t): with group of 4 terminal setae at centre and 3 at corner; moulted shell of Stage II remaining shows $8+8$ terminal setae (including lateral pair).

Dates of occurrence in plankton hauls: 26 August (Table 3).

Megalopa. Total length $9.0 \mathrm{~mm}$ (Fig. 23, 24).

Carapace (a): smooth with a supraorbital, antennal and pterygostomial spine and one or two median dorsal spines followed by two on the rostrum and one below as the rostrum expands below and rises toward the tip.

Abdomen: abdominal pleura rounded, beginning to resemble adult.

Antennule (c): first article about as long as other two combined, with stylocerite almost reaching distal end, each article with distal spine or spinous process; dilated flagellum with about 7 groups of aesthetes, 7 segments, 3 lateral and 2 terminal setae.

Antenna (d): scale with fringe of numerous setae (about 50) and distolateral spine shorter than blade; peduncle less than half length of scale, flagellum about as long as body.

Mandibles (e): incisor with 4 distal teeth, well-separated from molar.

Maxillule (f): proximal endite narrow and pointed with long curved setae, distal endite larger with distal rows of short strong sharp setae, plus one long plumose seta. Endopod short, curved, somewhat bifid with two apical and one lateral setae. 


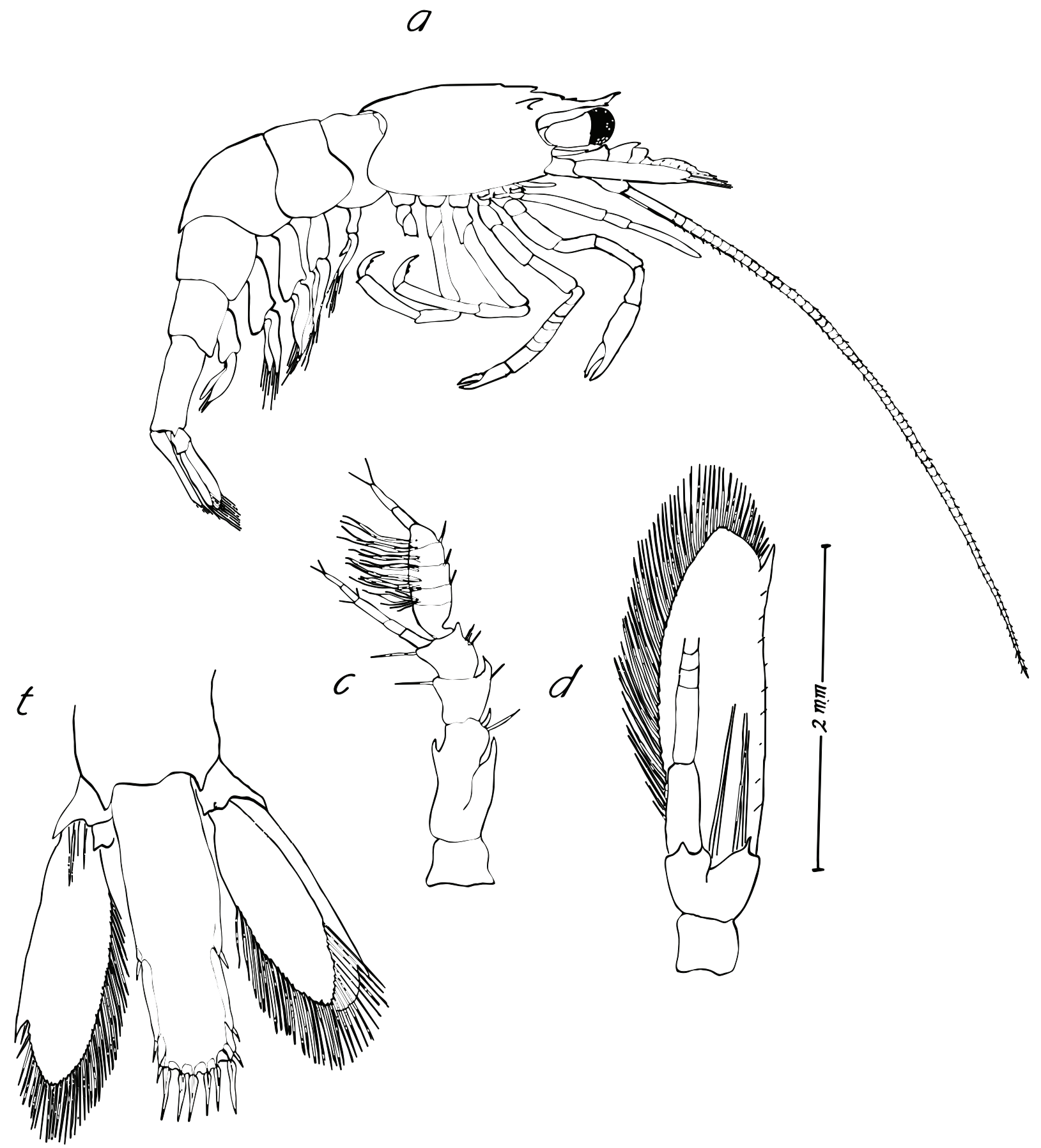

Fig. 23. Lebbeus polaris, Megalopa: (a) whole animal from right side; (c) antennule; (d) antenna; (t) telson. Scale as indicated. Broken line $=1 \mathrm{~mm}$.

Maxilla (g): proximal endite unilobed, somewhat reduced, bearing 8 plumose setae. Distal endite subequally bilobed. Endopod short. Anterior lobe of scaphognathite subrectilinear fringed with numerous setae (about 35), posterior lobe very narrow with 5-8 apical setae.

First maxilliped (h): endites fused with inner fringe of moderate setae; 4-segmented endopod shorter than exopod, the latter with 5 long apical plumose setae and bud of caridean lobe. Epipod large, bilobed. 


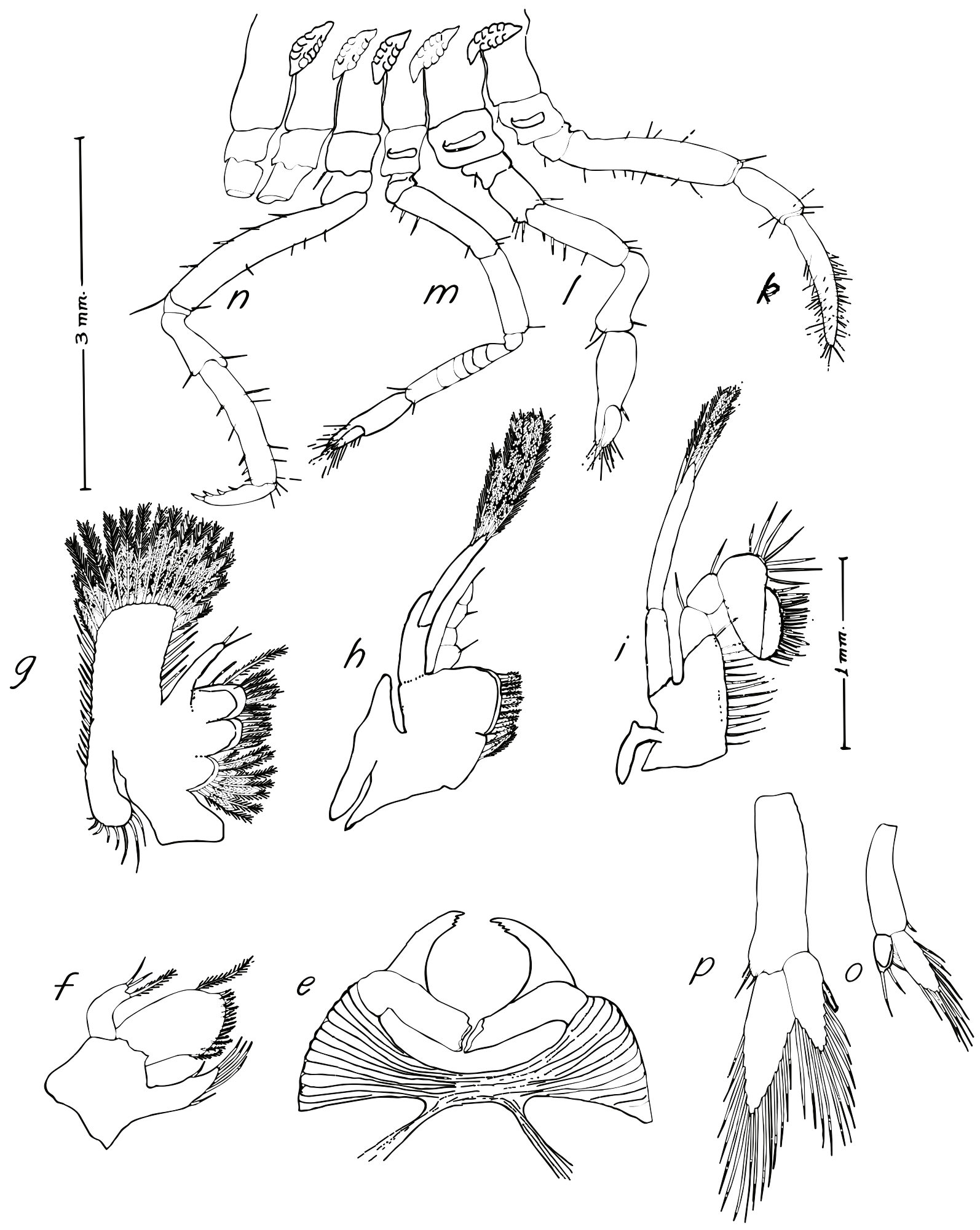

Fig. 24. Lebbeus polaris, Megalopa: (e) mandibles; (f) maxillule; (g) maxilla; (h) first maxilliped; (i) second maxilliped; (k) third maxilliped; (I) first pereopod; (m) second pereopod; (n) third pereopod; (o) first pleopod; (p) second pleopod. Scales as indicated. 
Second maxilliped (i): shaped somewhat as in adult, distal segment much wider than long. Exopod about twice length of endopod with about 5 apical setae. Epipod sock-shaped, with very small anterior lobe.

Third maxilliped (k): leg-like, slightly longer than first leg, small strap-shaped epipod with grappling hook. No exopod.

Pereopods: first $(\mathrm{I})$ and second $(\mathrm{m})$ strongly chelate, carpus of second with 7 divisions, small straplike epipods with hook. Third to fifth similar, dactyl stout with strong spines.

Pleopods: first (o) with endopod much shorter than exopod, second (p) with endopod shorter than exopod, with appendix interna.

Telson (t): with two pairs of terminal setae at centre and a long and short pair at each corner, also 3 pairs of small lateral spines.

Dates of occurrence in plankton hauls: 14-20 August (Table 3).

Genus Spirontocaris Bate, 1888

Haynes, 1985: 278.

This genus can be separated from other genera in Ungava Bay by the exopods on the first and second pereopods only. There are dorsolateral spines on abdominal somites 4 and 5 in all stages except megalopa.

\section{Spirontocaris phippsi (Krøyer, 1841)}

Pike and Williamson, 1961: 192; Haynes, 1985: 279.

The larvae of this species appear rather similar to $S$. spinus but are slightly larger at each stage. Telson may be more shallowly notched in Stage I Zoea than in S. spinus and spines at centre are not much smaller than others. Setae on scaphognathite (exopod of maxilla) are more numerous in this species than in S. spinus (Table 7). Total lengths $(\mathrm{mm})$ at the different zoeal Stages: I. 5.3-7.0, II. 8.0, III. 8.2, IV. 9-10.

Distribution in Ungava Bay: at stations throughout the bay: Cape Hopes Advance, Hopes Advance Bay, Inuksulik (1), Beacon Island, Adlorilik, Forbes Sound, near Port Burwell and Button Islands (Fig. 1; Table 1). No. of specimens taken = 345 (Table 2).

\section{Description}

Stage I Zoea. Total length 5.3-7.0 mm (Fig. 25, 26).

Carapace (a): with anterior tubercle, strong pterygostomian spine. Rostrum long but not exceeding peduncle of antennule.

Abdomen: with dorsolateral spines on somites 4 and 5.

Antennule (c): peduncle with 2 segments, the distal very short; outer flagellum conical with 3 distal aesthetes; inner flagellum only a long plumose seta.

Antenna $(d)$ : scale with fan of about 10 long plumose setae, exceeded by flagellum, the latter with 2 unequal spines distally. 


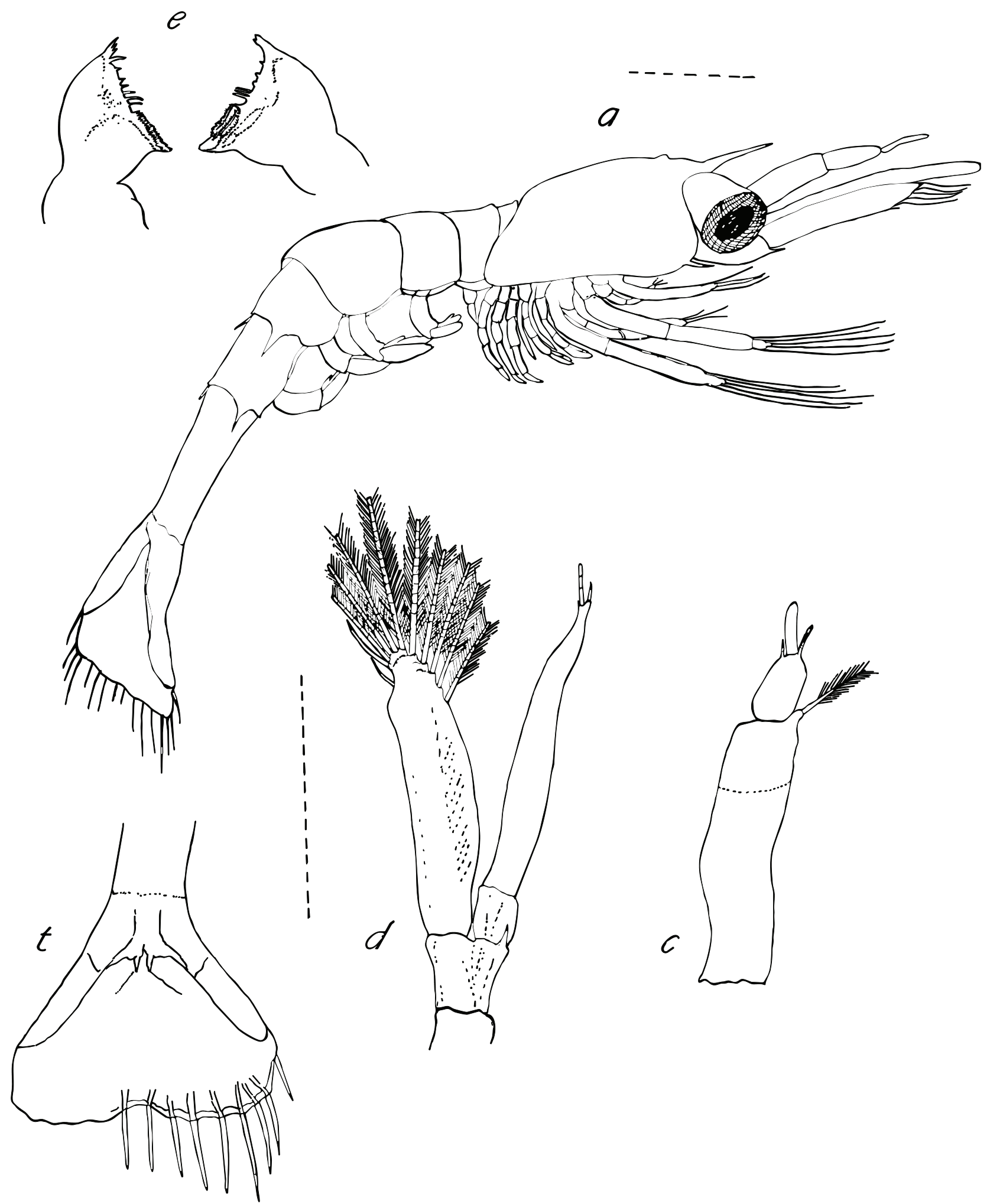

Fig. 25. Spirontocaris phippsi, Stage I Zoea: (a) whole zoea from right side; (c) antennule; (d) antenna; (e) mandibles; (t) telson. Broken line $=1 \mathrm{~mm}$. 


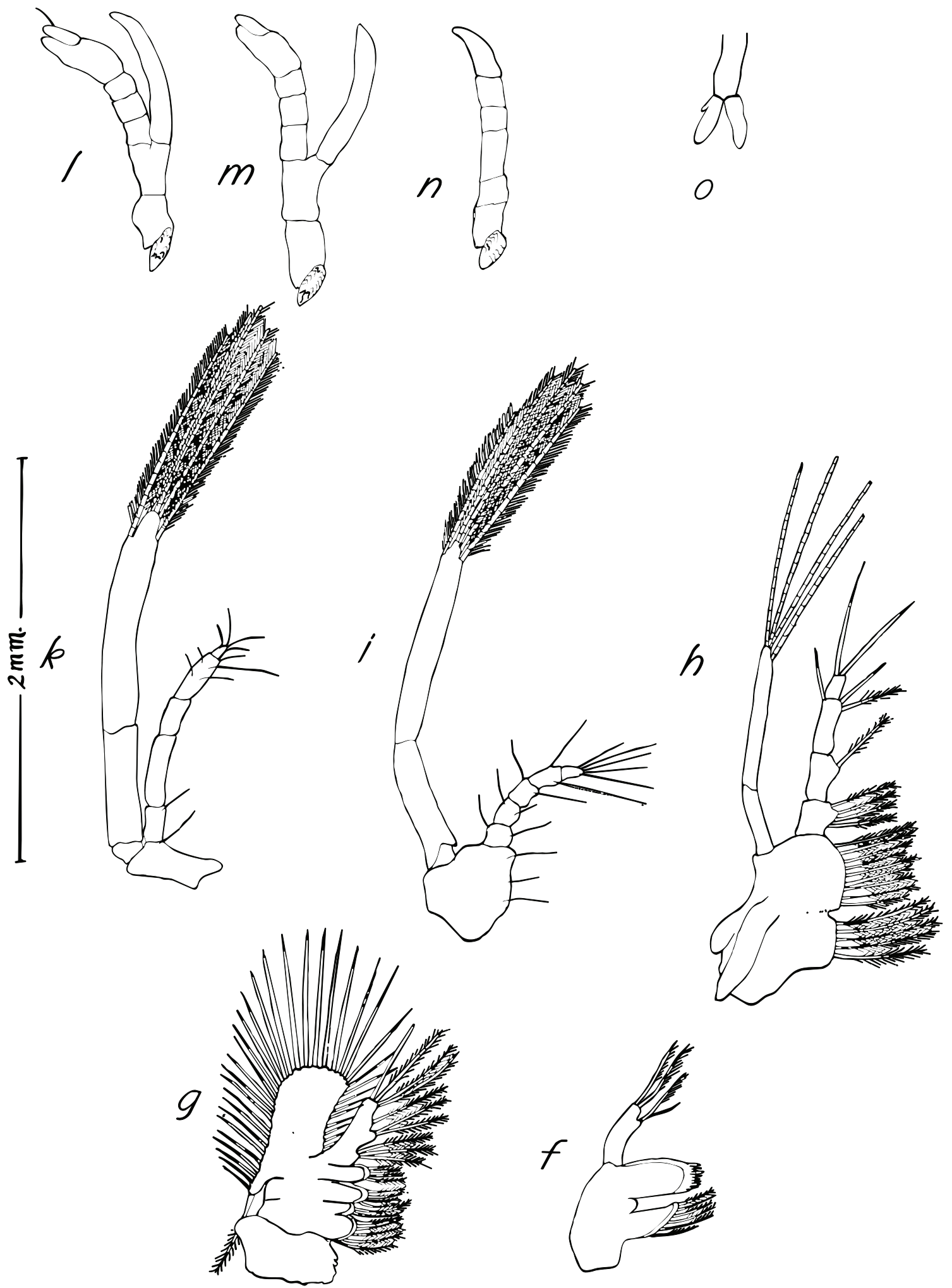

Fig. 26. Spirontocaris phippsi, Stage I Zoea: (f) maxillule; (g) maxilla; (h) first maxilliped; (i) second maxilliped; (k) third maxilliped; (I) first pereopod; (m) second pereopod; (n) third pereopod; (o) pleopod. Scale as indicated; broken line $=1 \mathrm{~mm}$. 
Mandibles (e): incisor of right with 4 teeth and series of about 7 denticles between it and molar, incisor of left with 2 teeth and series of about 5 denticles on thin edge joining it to stout molar.

Maxillule (f): endites about equal in width but distal more stout and with double row of stout spine-like setae distally. Endopod bifid each short branch with 2 setae distally.

Maxilla (g): proximal endite unequally bilobed, distal equally bilobed. Endopod slightly shorter than anterior lobe of scaphognathite, the latter with fringe of about 35 long plumose setae, posterior lobe only a short extension of proximal corner with a long strong seta.

First maxilliped (h): endites wide, slightly unequal. Endopod with 4 divisions, almost as long as exopod, the latter with 4 long distal setae. Epipod small.

Second maxilliped (i): endopod of 5 divisions much shorter than exopod, the latter with 5 long apical setae.

Third maxilliped $(\mathrm{k})$ : endopod of 5 divisions about two-thirds as long as exopod, the latter with 5 long plumose apical setae.

Pereopods: only first $(\mathrm{I})$ and second $(\mathrm{m})$ chelate and with exopods.

Pleopods (o): biramous, small.

Telson (t): with $8+8$ terminal setae with only slightly smaller pair at centre, very shallowly notched (deeper notched in S. spinus).

Dates of occurrence in plankton hauls: 26 June-14 July (Table 3).

Late Stage II Zoea. Total length 8.0 mm (Fig. 27, 28).

Carapace (a): with anterior and posterior tubercle, supraorbital and pterygostomial spines, a faint cervical groove. Rostrum long, exceeding eye but not reaching distal antennular peduncle.

Abdomen: smooth with dorsolateral spine on somites 4 and 5.

Antennule (c): peduncle with short distal segment; inner flagellum short and pointed with distal seta, outer with 5 groups of aesthetes and very short terminal portion.

Antenna (d): scale with distolateral spine shorter than lamella, and fan of about 30 long setae, shorter than unsegmented flagellum.

Mandibles (e): incisor of right with 3 and of left with 4 teeth, joined to stout molar with straight thin edge armed with about 7 denticles.

Maxillule (f): proximal endite pointed and with distal curved setae, distal endite larger with distally 2 rows of short spine-like setae; endopod bifid, distal branch with 3 and lateral with one seta.

Maxilla (g): proximal endite large bilobed, one lobe very small; distal endite subequally bilobed. Endopod short somewhat truncate; anterior lobe of scaphognathite slightly expanded distally with fringe of about 35 setae, posterior lobe a short extension of proximal corner and with one long posterior seta. 


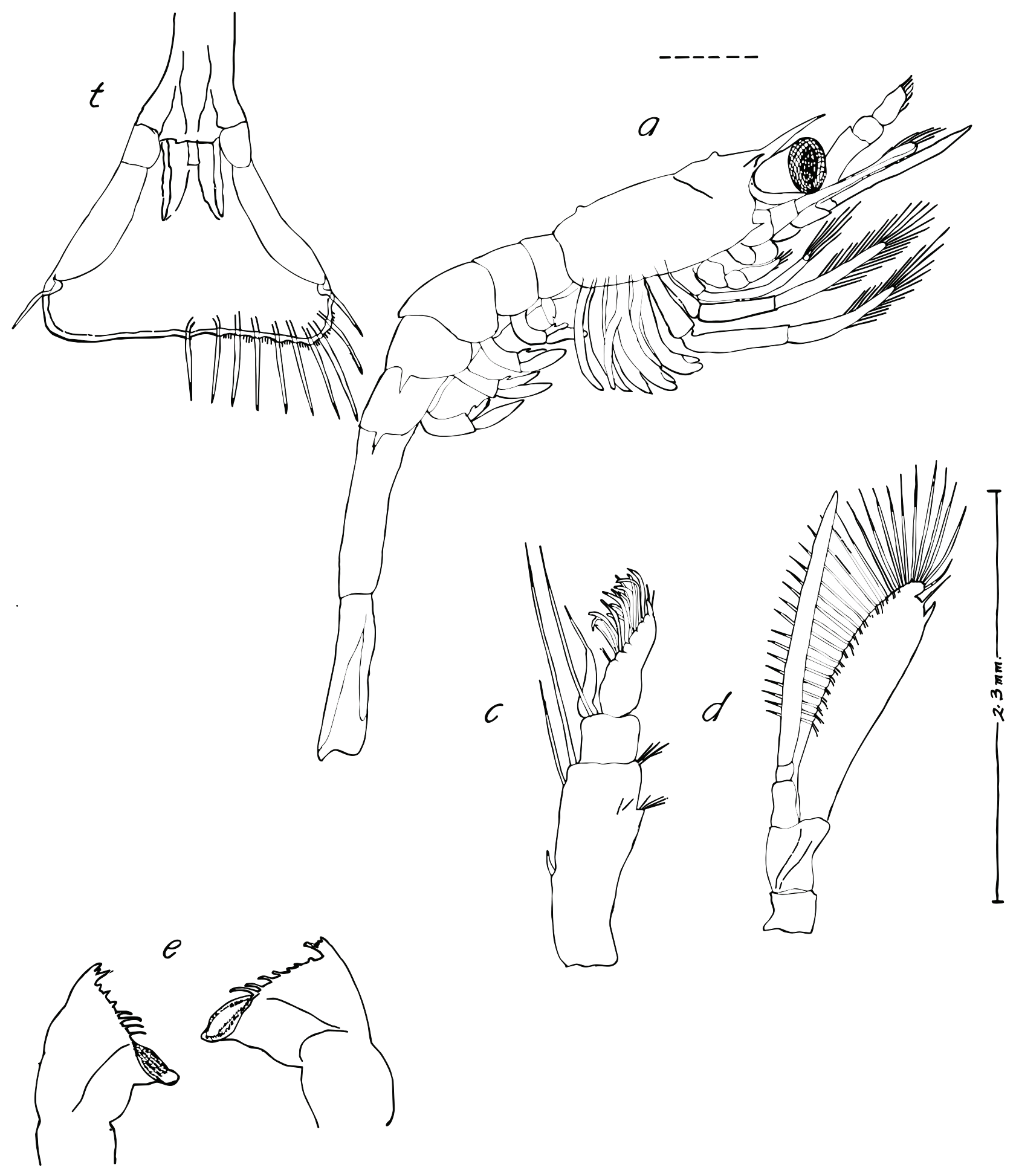

Fig. 27. Spirontocaris phippsi, Stage II Zoea: (a) whole zoea from right side; (c) antennule; (d) antenna; (e) mandibles; (t) telson. Broken line $=1 \mathrm{~mm}$, other scale as indicated. 


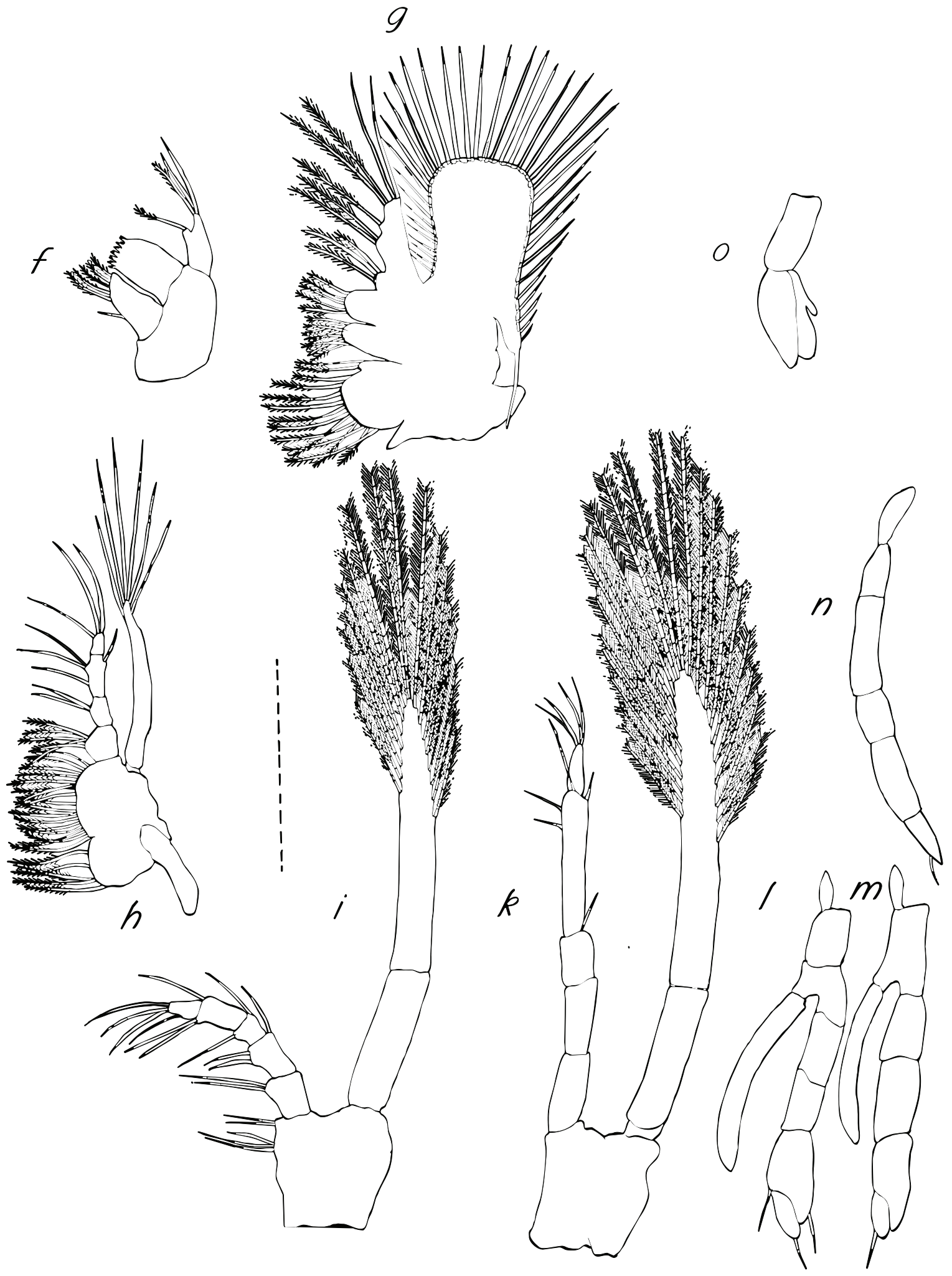

Fig. 28. Spirontocaris phippsi, Stage II Zoea: (f) maxillule; (g) maxilla; (h) first maxilliped; (i) second maxilliped; (k) third maxilliped; (I) first pereopod; $(\mathbf{m})$ second pereopod; (n) third pereopod; (o) pleopod. Broken line $=1 \mathrm{~mm}$. 
First maxilliped $(h)$ : proximal endite slightly smaller than distal both with long inner setal fringe. Endopod with 4 divisions, almost as long as slender exopod, the latter with 6 apical long setae.

Second maxilliped (i): endopod of 5 divisions much shorter than long exopod, the latter with 16 long apical setae.

Third maxilliped ( $k$ ): endopod of 5 divisions, almost as long as exopod, the latter with about 22 long apical setae.

Pereopods: only first $(\mathrm{I})$ and second $(\mathrm{m})$ with chela and exopod.

Pleopods (o): well-developed, 2-5 biramous and with appendix interna.

Telson (t): with very shallow notch and $8(9)+8(9)$ terminal setae, those at centre not much smaller than others.

Dates of occurrence in plankton hauls: 13 July-3 August (Table 3).

Stage III Zoea. Total length 8.2 mm (Fig. 29, 30).

Carapace (a): smooth, supraorbital, antennal and pterygostomial spines. Rostrum long, slender, about even with eye.

Abdomen: with small dorsolateral spine on somites 4 and 5.

Antennule (c): first article longer than others combined, stylocerite very short, inner lateral spine on distal third; outer flagellum subconical with short slender pointed distal part and 5 groups of aesthetes, inner flagellum about half as long with two long setae at base.

Antenna (d): scale with fan of numerous setae and distolateral spine exceeded by blade; flagellum longer than scale, non-segmented.

Mandible (e): left incisor with 3 and right with 2 teeth followed by 6 and 4 denticles, respectively, on thin edge between it and stout molar.

Maxillule (f): proximal endite thin and pointed with a few distal setae; distal endite wider and with double row of stout spine-like setae distally. Endopod short, obscurely bifid with 3 distal and 2 lateral setae.

Maxilla (g): proximal endite unequally bilobed with long curved setae; distal endite subequally bilobed. Endopod shorter than anterior lobe of scaphoganthite, the latter slightly expanded distally with about 31 fringing setae, the posterior lobe small and narrow with terminal long seta.

First maxilliped (h): endites fused, with long setal fringe. Endopod with 4 divisions the distal very narrow, almost as long as narrow exopod, the latter with about 6 apical setae; epipod present.

Second maxilliped (i): endopod with 5 segments, almost as long as exopod, the latter with about 16 long setae distally.

Third maxilliped $(\mathrm{k})$ : endopod 5-segmented, almost as long as long exopod, the latter with about 24 distal setae.

Pereopods: first $(\mathrm{I})$ and second $(\mathrm{m})$ only with exopods and chelate, the propodus much longer than dactyl. 


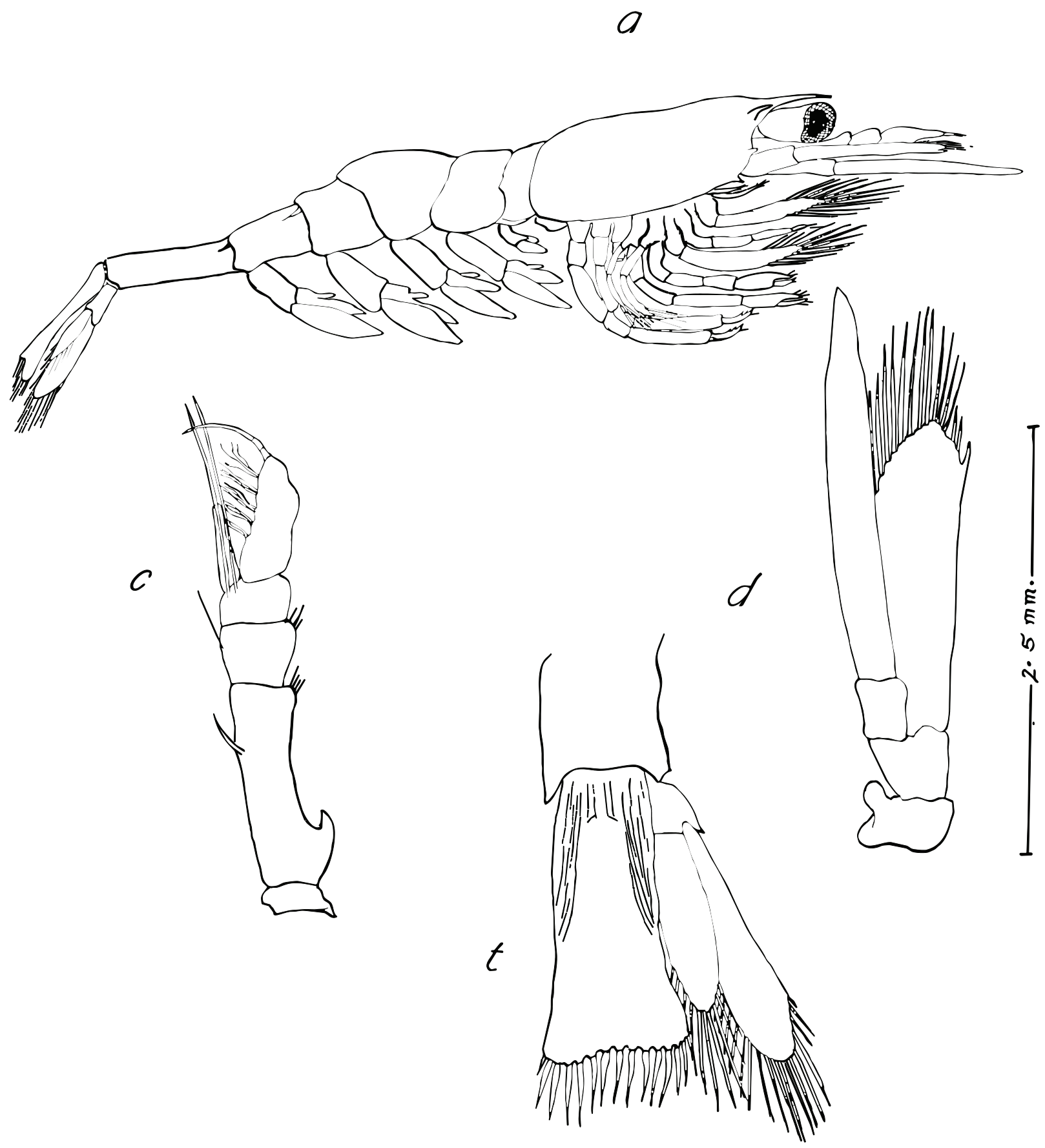

Fig. 29. Spirontocaris phippsi, Stage III Zoea: (a) whole zoea from right side; (c) antennule; (d) antenna; (t) telson. Scale as indicated, broken line $=1 \mathrm{~mm}$.

Pleopods (o): well-developed, appendix interna present.

Telson (t): slightly widened distally and with $8+8$ setae, those at centre only slightly smaller than others.

Dates of occurrence in plankton hauls: 20 July-27 August (Table 3). 


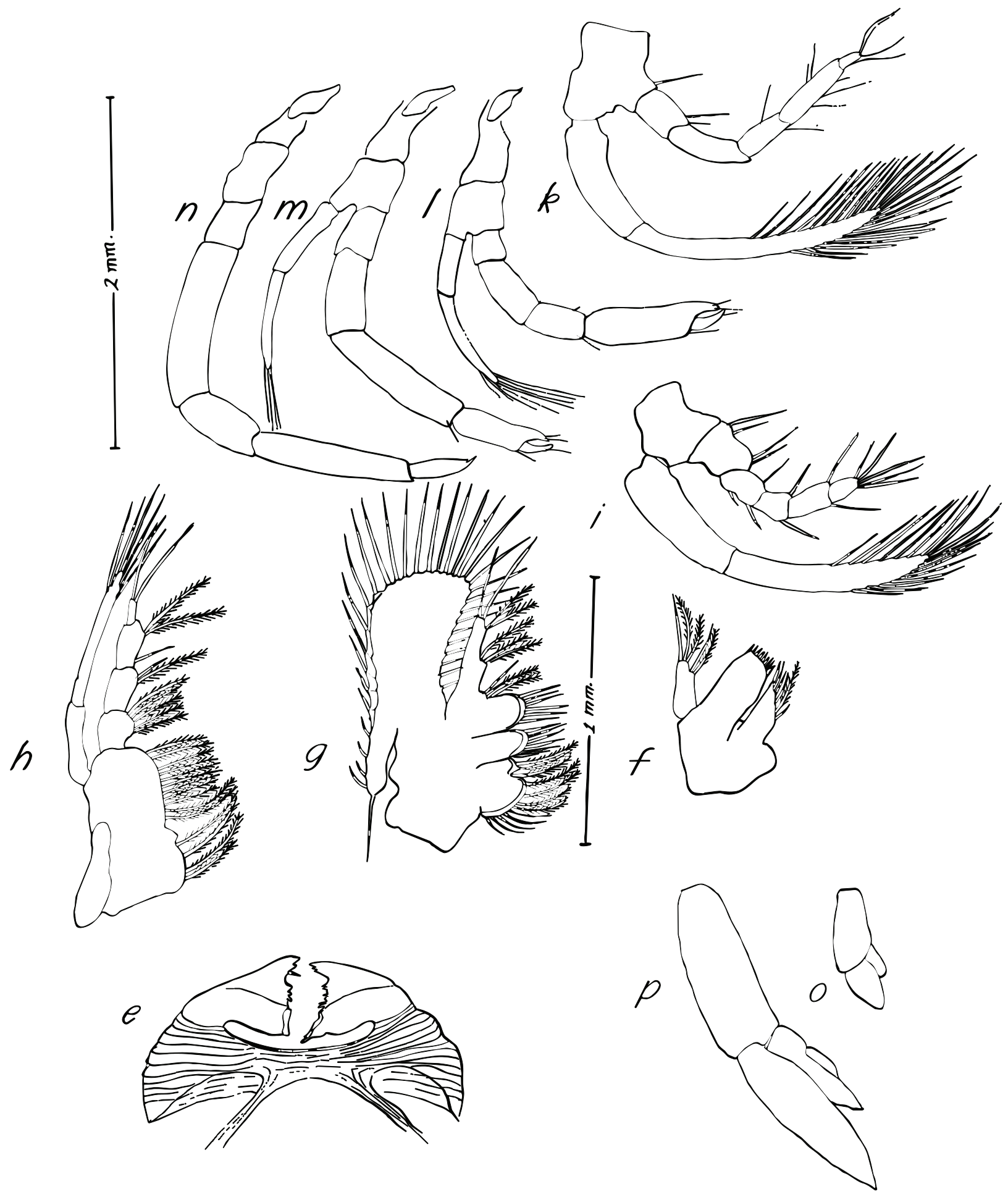

Fig. 30. Spirontocaris phippsi, Stage III Zoea: (e) mandibles; (f) maxillule; (g) maxilla; (h) first maxilliped; (i) second maxilliped; (k) third maxilliped; (I) first pereopod; (m) second pereopod; (n) third pereopod; (o) first pleopod; (p) second pleopod. Scales as indicated. 
Stage IV Zoea. Total length 9.0-10.4 mm (Fig. 31).

Carapace (a): with long supraorbital spine closer to front of carapace than in S. spinus, small antennal and pterygostomial spines; anterior and posterior median tubercles. Rostrum short, not reaching beyond eye.

Abdomen: with dorsolateral spines on abdominal somites 4 and 5 .

Antennule (c): first article with short stylocerite on proximal quarter; outer flagellum with distal projection and 5 groups of lateral aesthetes.

Antenna $(\mathrm{d})$ : distolateral spine about even with tip of blade, fringe of about 25 setae; flagellum longer than scale.

Mandible (e): incisor with 4 descending teeth and small denticle followed by 3 moderate teeth and 3 close denticles and short gap to rough molar.

Maxillule (f): proximal endite with about 8 stout curved setae apically, slightly smaller than robust distal endite with rows of stout spine-like setae apically. Endopod bifid with 3 apical and 2 lateral setae.

Maxilla (g): proximal endite with one very narrow and one wide lobe with curved long setae; distal endite with subequal lobes. Endopod almost as long as anterior lobe of scaphognathite, the latter with fringe of about 30 setae; posterior lobe narrow with one apical seta.

First maxilliped (h): proximal endite slightly shorter than distal, endopod with 4 segments. Exopod with 4 apical long setae. Epipod present.

Second maxilliped (i): short with 5 segments; exopod much longer, with about 15 apical setae.

Third maxilliped (k): endopod almost as long as exopod, the latter with about 15 apical setae.

Pereopods: first $(\mathrm{I})$ and second $(\mathrm{m})$ chelate and with exopod. The third to the fifth are about as long as the second but without exopod.

Pleopods (o): all biramous, and except the first, have appendix interna.

Telson $(\mathrm{t})$ : with $8+8$ terminal setae all very similar in length except at corner, one small lateral spine on distal quarter.

Date of occurrence in plankton haul: 26 August (Table 3).

Spirontocaris spinus (Sowerby, 1805)

Pike and Williamson, 1961: 187, fig. 1 a,b, d-r;

Haynes, 1985: 279.

Similar in appearance to $S$. phippsi but slightly smaller at each stage. In Stage I Zoea, the telson is more deeply notched than in S. phippsi, and at Stages I-IV the telson spines have a very short pair at the centre. Also the scaphognathite has fewer fringing setae than in S. phippsi (Table 7). Total lengths (mm) at the different zoeal Stages are as follows: I. 4.6-5.6, II. 5.5-6.5, III. 6.4-7.6, IV. 8.5-9.4, Megalopa. 7.8-9.0. 


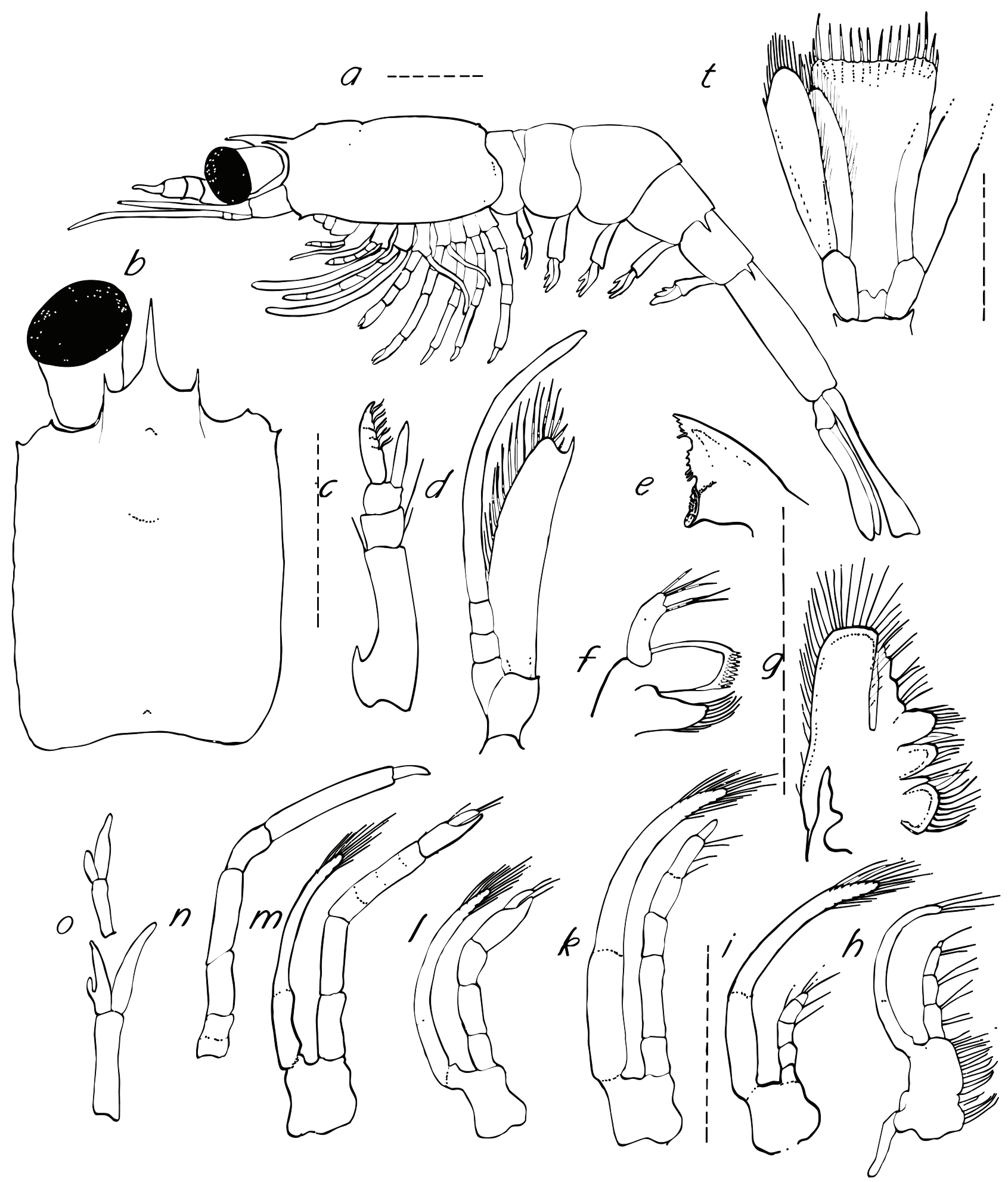

Fig. 31. Spirontocaris phippsi, Stage IV Zoea: (a) whole zoea from left side; (b) dorsal carapace; (c) antennule; (d) antenna; (e) mandible; (f) maxillule; (g) maxilla; (h) first maxilliped; (i) second maxilliped; (k) third maxilliped; (I) first pereopod; (m) second pereopod; (n) third pereopod; (o) pleopods. Broken line $=1 \mathrm{~mm}$. 
Distribution in Ungava Bay: east of Tuvalik, Hopes Advance Bay, Inuksulik (1), Leaf Bay, Koksoak River mouth, Keglo Bay, Adlorilik, near Port Burwell and Button Islands (Fig. 1; Table 1). No. of specimens taken $=655$ (Table 2).

\section{Description}

Stage I Zoea. Total length 4.6-5.6 mm (Fig. 32, 33).

Carapace (a): without supraorbital spine, with anterior and slightly smaller posterior tubercle, anteroventral denticles about 4, pterygostomial spine. Rostrum elongate exceeding peduncle of antennule. Eyes large, not free.

Abdomen: smooth, with dorsolateral spines on somites 4 and 5.

Antennule (c): appearing to have division near middle of peduncle; outer flagellum short subconical with 3 aesthetes, inner a short projection with long plumose seta.

Antenna (d): scale 6-segmented at tip, exceeding distolateral spine, with fan of about 10 setae; flagellum shorter than scale with two unequal apical spines.

Mandibles (e): left incisor with 4 teeth and 4 denticles on thin edge between it and stout molar, right incisor with 2 teeth and 3 denticles between it and molar.

Maxillule (f): proximal endite smaller than distal, with a few curved setae distally; distal endite with double row of short stout spine-like setae. Endopod obscurely bifid, the distal branch with 3 and the lateral with 2 setae.

Maxilla (g): proximal endite unilobate, distal endite equally bilobed, both with setal fringe. Endopod shorter than anterior lobe of scaphognathite, the latter with only 4 long setae, its posterior lobe still not in evidence but with a strong posterior seta and an anteriorly directed seta attached.

First maxilliped (h): endites fused, with few setae at inner edge. Endopod with 4 divisions, exopod slightly longer with 3 or 4 simple apical setae.

Second maxilliped (i): exopod much longer than 5-segmented endopod, with 5 long plumose apical setae.

Third maxilliped (k): exopod large only slightly longer than 5-segmented endopod, with 5 long plumose apical setae.

Pereopods: first $(\mathrm{I})$ and second $(\mathrm{m})$ with exopod but undeveloped with few divisions. The third to fifth without exopods.

Pleopods: small buds only.

Telson (t): with $7+7$ terminal setae, the centre pair very short.

Dates of occurrence in plankton hauls: 3-20 July (Table 3).

Stage II Zoea. Total length 5.5-6.5 mm (Fig. 34, 35).

Carapace (a): with supraorbital spine, small anterior median tubercle, anteroventral denticles about 4, pterygostomial spine. Rostrum wide at base but long, exceeding first two segments of antennule. Eyes large, free. 

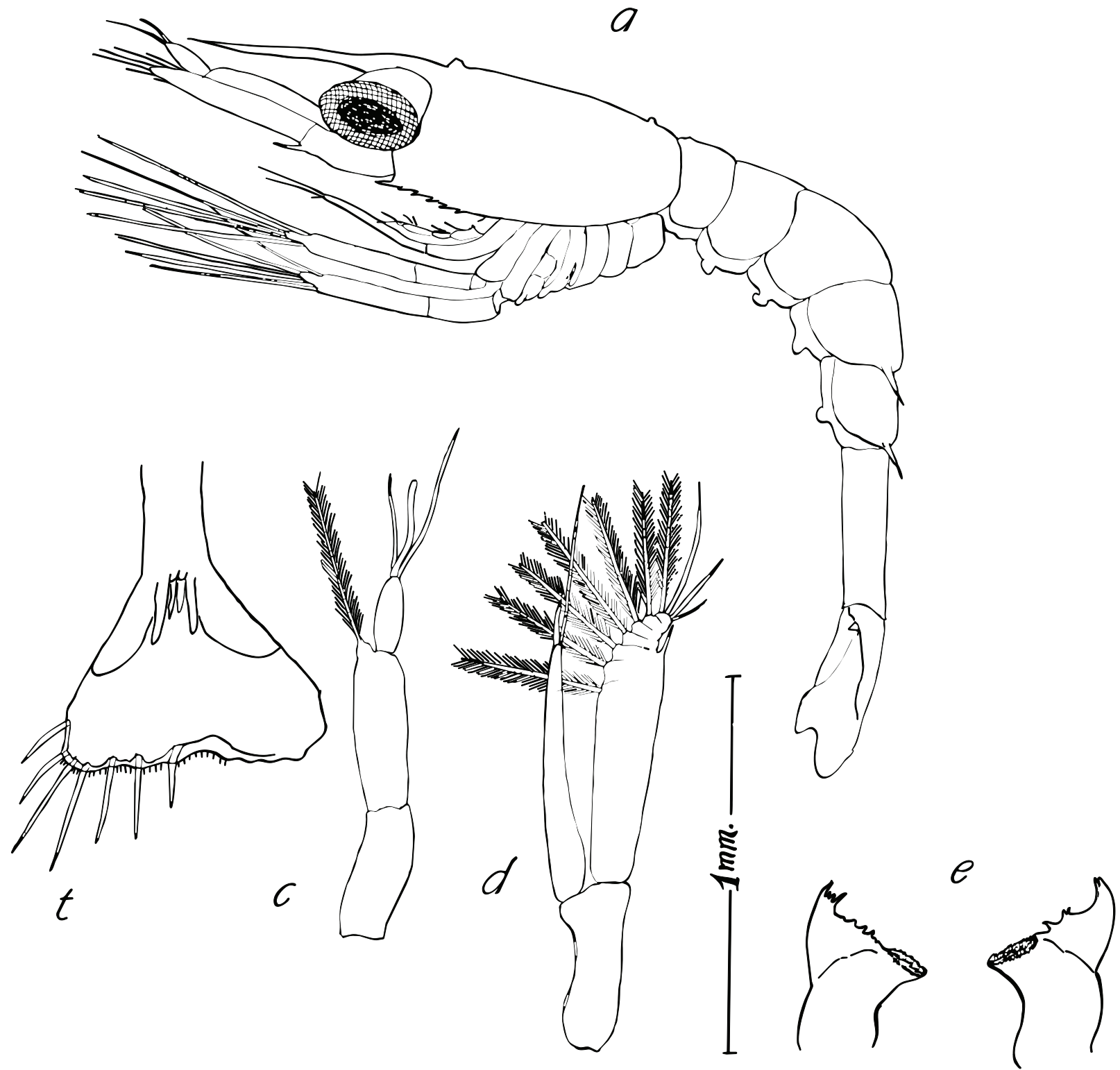

Fig. 32. Spirontocaris spinus, Stage I Zoea: (a) whole zoea from left side; (c) antennule; (d) antenna; (e) mandibles; (t) telson. Scale as indicated, broken line $=1 \mathrm{~mm}$.

Abdomen: with dorsolateral spines on somites 4 and 5.

Antennule (c): first article divided from second, the latter longer than the third; outer flagellum inflated, with 3 apical setae; inner flagellum short unsegmented with long setae near base.

Antenna (d): tip of scale not clearly segmented, fan of about 20 setae, distolateral spine slightly exceeding blade; flagellum not as long as scale and with a short and a long apical spinous seta. 


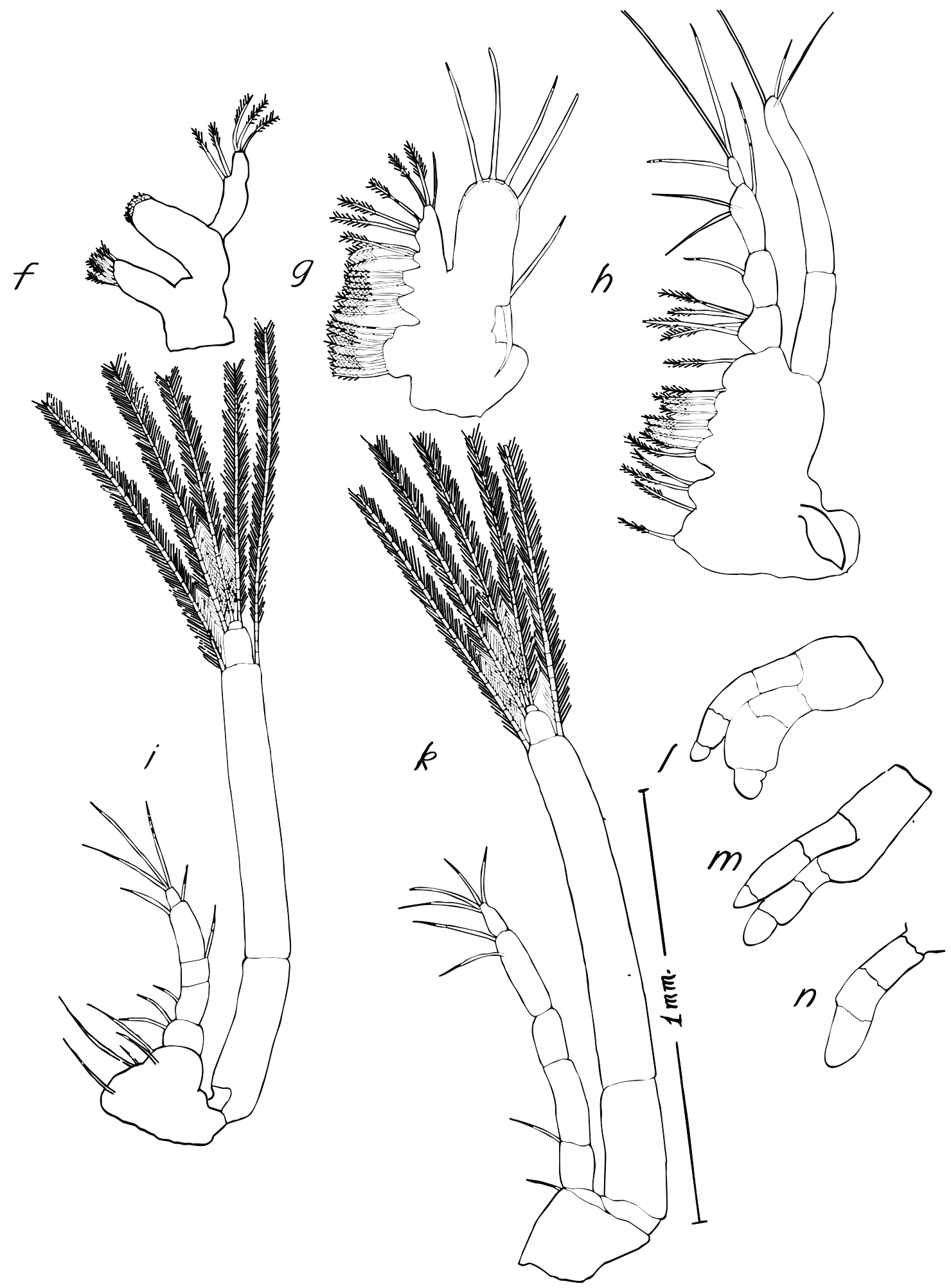

Fig. 33. Spirontocaris spinus, Stage I Zoea: (f) maxillule; (g) maxilla; (h) first maxilliped; (i) second maxilliped; (k) third maxilliped; (I) first pereopod; (m) second pereopod; (n) third pereopod. Scale as indicated. 

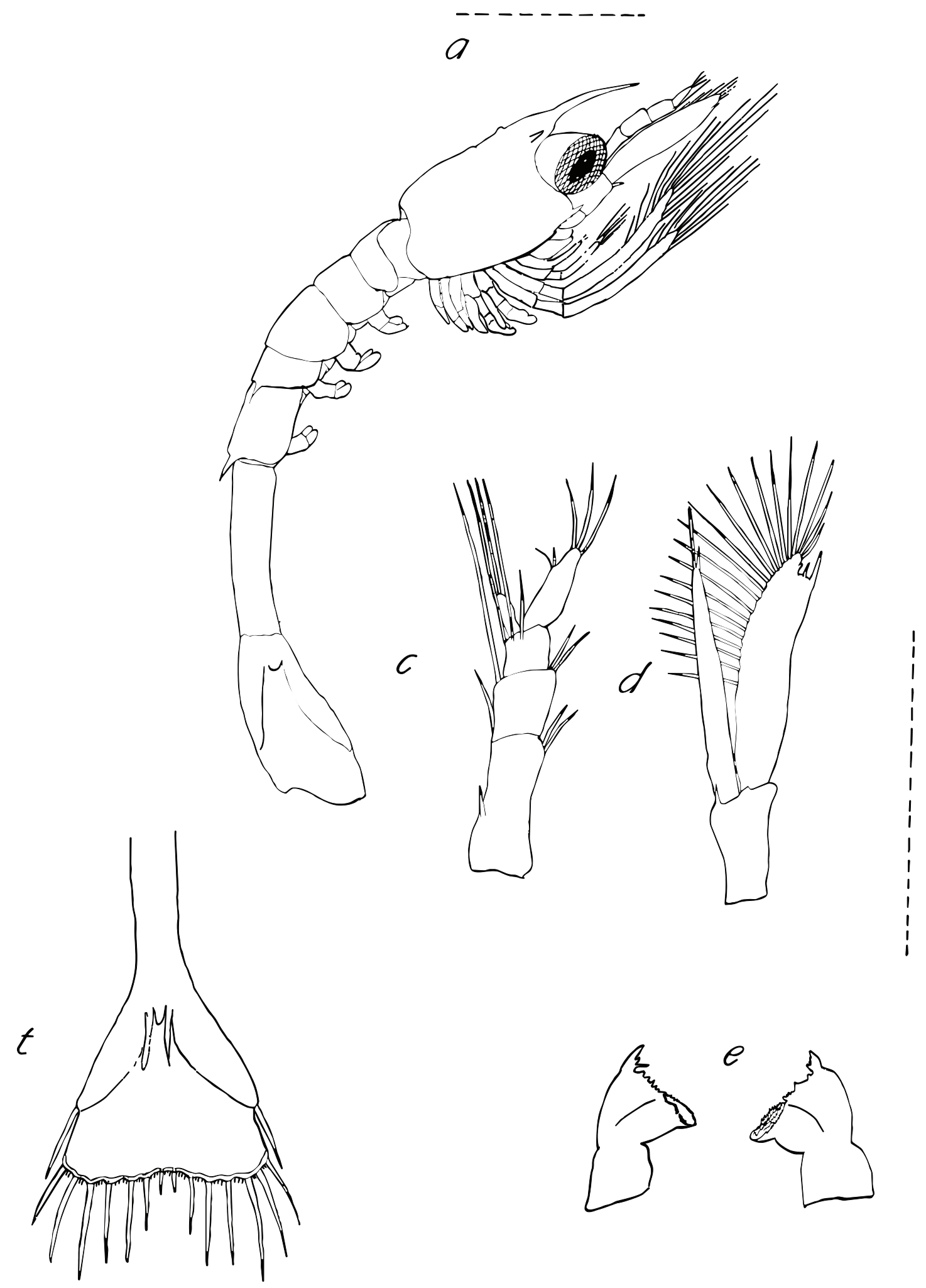

Fig. 34. Spirontocaris spinus, Stage II Zoea: (a) whole zoea from right side; (c) antennule; (d) antenna; (e) mandibles; (t) telson. Broken line $=1 \mathrm{~mm}$. 


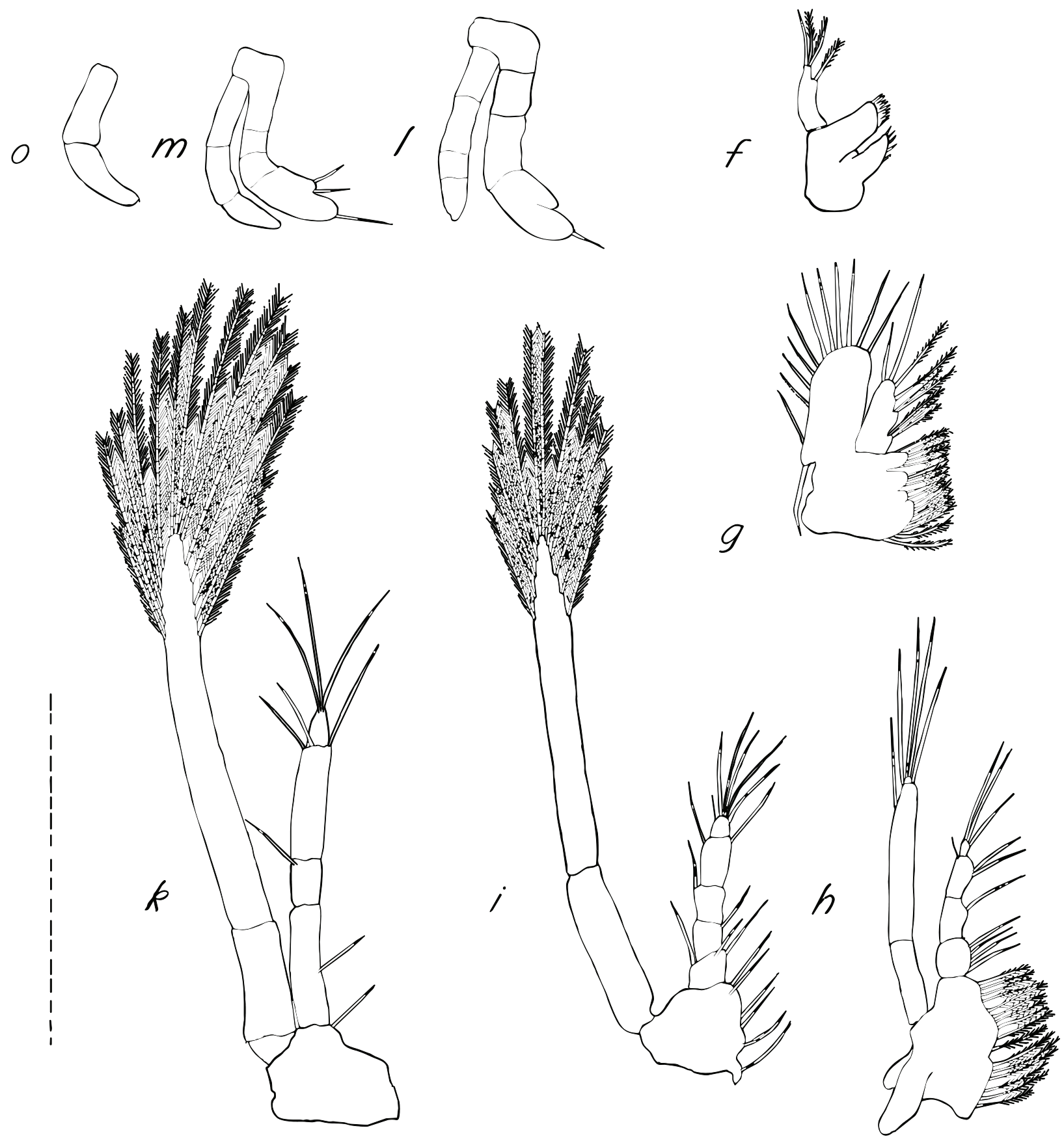

Fig. 35. Spirontocaris spinus, Stage II Zoea: (f) maxillule; (g) maxilla; (h) first maxilliped; (i) second maxilliped; (k) third maxilliped; (I) first pereopod; (m) second pereopod; (o) pleopod. Broken line $=1 \mathrm{~mm}$.

Mandibles (e): left incisor with 3 teeth and about 5 denticles between it and stout molar; right incisor with 4 teeth and a larger denticle plus a group of 4 small denticles between it and molar.

Maxillule (f): proximal endite pointed and with few setae, smaller than distal endite, the latter with 2 rows of short spine-like distal setae. 
Maxilla (g): proximal endite obscurely and unequally bilobed; distal endite subequally bilobed with long fringing plumose setae. Endopod shorter than anterior lobe of scaphognathite, the latter with a fringe of about 10 setae, posterior lobe a very short extension of corner with long terminal spine also an anteriorly directed seta.

First maxilliped (h): endites fused with long plumose fringing setae. Endopod with 4 divisions shorter than exopod, the latter with 5 long apical setae.

Second maxilliped (i): endopod much shorter than long exopod, the latter with 12 long apical setae.

Third maxilliped $(k)$ : endopod with 4 divisions about two-thirds as long as exopod, the latter with about 14 long apical setae.

Pereopods: first $(\mathrm{I})$ and second $(\mathrm{m})$ preliminarily chelate with exopod. The third to fifth without exopod.

Pleopods (o): short, biramous.

Telson (t): with $8+8$ terminal setae, the centre pair very short.

Dates of occurrence in plankton hauls: 29 June-27 July (Table 3).

Stage III Zoea. Total length 6.4-7.6 mm (Fig. 36).

Carapace (a): with anterior and posterior tubercles, supraorbital and pterygostomial spines (followed by 3 anteroventral denticles in some specimens). Rostrum long and styliform, about even with distal cornea.

Abdomen: with dorsolateral spines on somites 4 and 5, longer on fourth.

Antennule (c): with no sign of stylocerite; outer flagellum with apical and one group of lateral aesthetes; inner flagellum short with setae beside it.

Antenna (d): scale with distolateral spine exceeding blade, slightly concave, fringe of setae about 16; flagellum slightly longer than scale, tipped with a short spine.

Mandible (e): incisor pointed with 2 descending small teeth and a moderate denticle, followed by a slight rise and a denticle to reach the stout molar.

Maxillule (f): proximal endite narrow, slightly curved, tipped with 4 strong curved setae; distal almost straight, wide, tipped with 2 rows of stout spine-like setae. Endopod bifid, with 3 apical and 2 lateral setae.

Maxilla (g): proximal endite with lobes very unequal, strong curved setae; distal with subequal lobes. Endopod short, tip somewhat truncate with 3 setae. Anterior lobe of scaphognathite longer than endopod, with fringe of only about 10 setae, posterior lobe very short with tip of one lone spine and a retrorse seta about as long.

First maxilliped (h): endopod 4-segmented, shorter than slender exopod, the latter with tip of about 6 setae. Epipod present.

Second maxilliped (i): endopod short, obscurely 5-segmented; exopod about twice as long, tipped with about 12 long setae. 


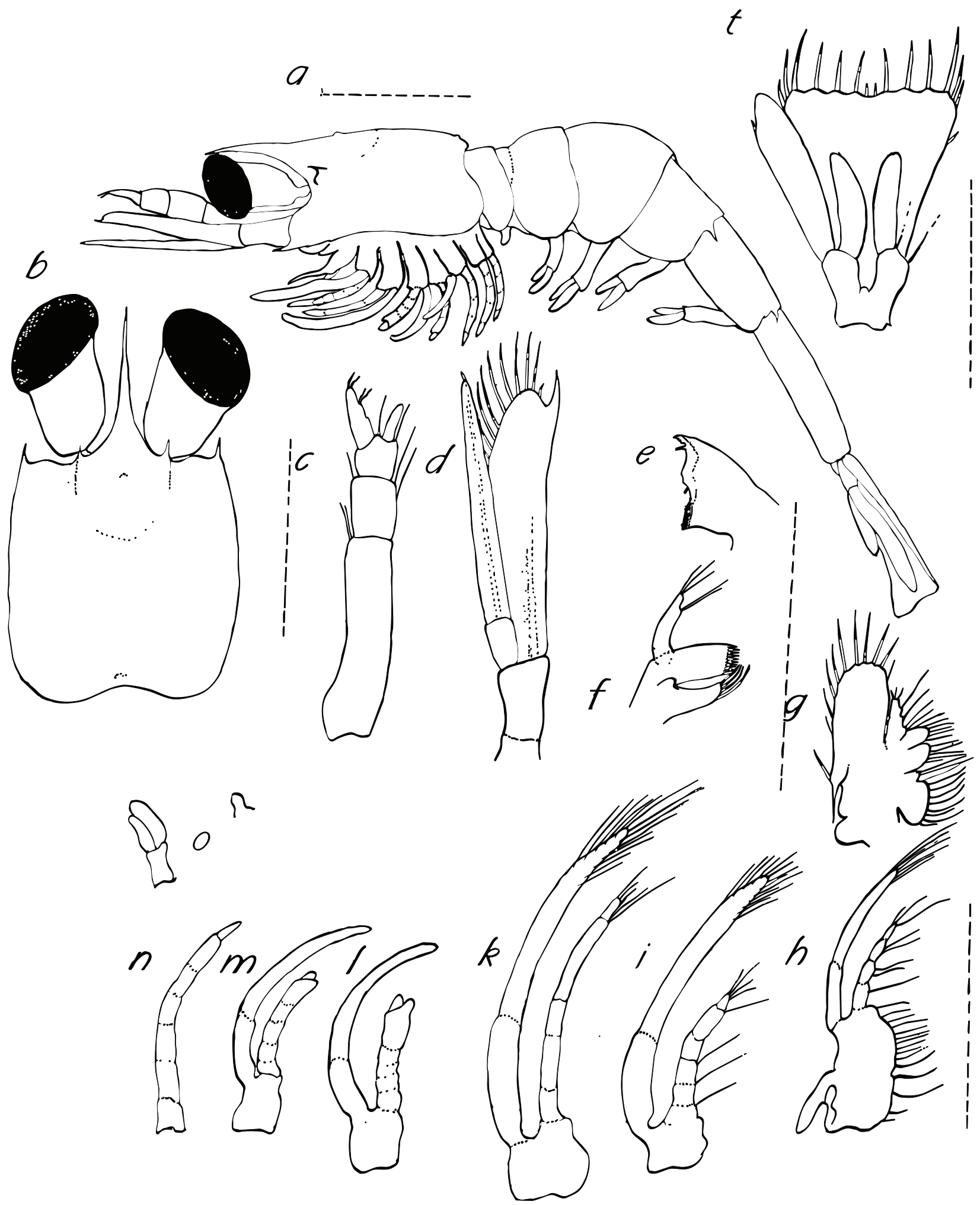

Fig. 36. Spirontocaris spinus, Stage III Zoea: (a) whole zoea from left side; (b) dorsal carapace; (c) antennule; (d) antenna; (e) mandible; (f) maxillule; (g) maxilla; (h) first maxilliped; (i) second maxilliped; (k) third maxilliped; (I) first pereopod; (m) second pereopod; (n) third pereopod; (o) pleopods; (t) telson. Broken line $=1 \mathrm{~mm}$. 
Third maxilliped $(\mathrm{k})$ : endopod obscurely 5-segmented almost as long as exopod, the latter tipped with about 12 long setae.

Pereopods: first (I) obscurely segmented, with propodus slightly extended distally forming incipient chela with short dactyl, exopod. The second $(m)$ similar to the first but more slender, exopod. The third (n) to fifth longer than the second, obscurely segmented. No exopods.

Pleopods: first (o) only a small bud. The second $(p)$ to fifth biramous but without appendix interna.

Telson (t): $7+7$ terminal setae the centre pair very small, a small lateral spine in addition; outer branch of uropod with small distolateral spine.

Dates of occurrence in plankton hauls: 13 July-3 August (Table 3).

Stage IV Zoea. Total length 8.5-9.4 mm (Fig. 37).

Carapace (a and b): with anterior and small posterior tubercles; strong supraorbital and pterygostomial spine. Rostrum slender, long, reaching beyond eye and about the middle of the 2nd antennular article.

Abdomen: abdominal somites 4 and 5 with dorsolateral spine.

Antennule (c): first article with an outer tooth on proximal fifth and a ventral spine on distal onequarter; inner flagellum about as long as outer, the latter with a distal aesthete and 2 setae and 3 clumps of lateral setae; 2 long setae beside inner flagellum.

Antenna (d): flagellum exceeding scale, the latter with a very long distolateral spine much exceeding the blade, fringing setae about 25 .

Mandible (e): incisor pointed and with 3 small teeth followed by sharp lateral denticle and curved thin edge reaching molar, the latter roundish truncate with many minute cusps.

Maxillule (f): proximal endite narrow, curved, with distal curved setae; distal endite with 2 rows of short stout spine-like setae. Endopod slender with 3 distal and 2 lateral setae.

Maxilla (g): endopod shorter than anterior lobe of the scaphognathite, the latter with fringe of about 20 setae, short narrow posterior lobe has terminal long spine. Proximal endite with unequal lobes and long curved setae, distal endite with equal lobes and few setae.

First maxilliped (h): endopod with 5 divisions almost as long as narrow exopod, the latter with about 5 apical setae; long slender epipod.

Second maxilliped (i): endopod short with 4 clear divisions, exopod much longer and with about 12 apical setae.

Third maxilliped (k): endopod almost as long as exopod, the latter with about 12 apical setae.

Pereopods: first $(\mathrm{I})$ and second $(\mathrm{m})$ with exopods, with several divisions, clearly forming chelae. The third (n) to fifth without exopods, dactyl long and pointed.

Pleopods: all biramous and with appendix interna. 


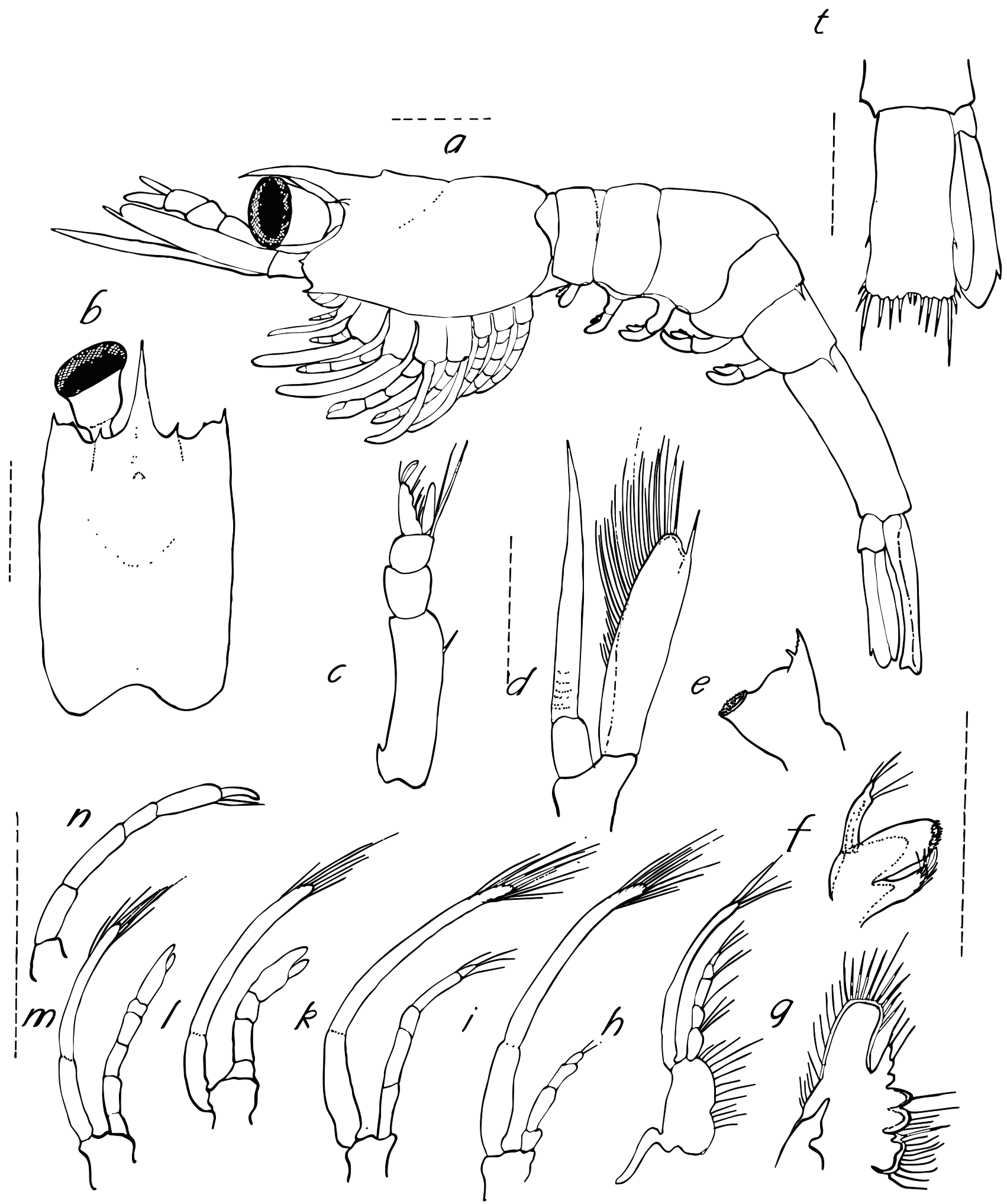

Fig. 37. Spirontocaris spinus, Stage IV Zoea: (a) whole zoea from left side; (b) dorsal carapace; (c) antennule; (d) antenna; (e) mandible; (f) maxillule; (g) maxilla; (h) first maxilliped; (i) second maxilliped; (k) third maxilliped; (I) first pereopod; (m) second pereopod; (n) third pereopod; (t) telson. Broken line $=1 \mathrm{~mm}$. 
Telson (t): with $7+7$ terminal setae, the corner pair the longest by much (plus 2 short lateral setae), centre pair very short and close. One pair of lateral spines on distal third. Branches of uropod about even with tip, the inner slightly shorter.

Dates of occurrence in plankton hauls: 10-28 August (Table 3).

Megalopa. Total length 7.8-9.0 mm (Fig. 38, 39).

Carapace (a): with stout supraorbital spine, antennal and pterygostomial spine; also a small median epigastric tooth. Rostrum stout, short.

Abdomen: without dorsolateral spines on somites 4 or 5 .

Antennule (c): first article long with inner distal spine and outer stylocerite sharp point reaching about half article. Outer flagellum with 5 clumps of aesthetes and short slender distal section.

Antenna (d): scale lamella exceeding distolateral spine, with fringe of numerous setae, flagellum almost as long as the total length.

Mandibles (e): incisor with 3 distal teeth, well separated from stout molar.

Maxillule (f): proximal endite small, curved and pointed with long curved setae; distal endite large and wide with double row of stout spine-like setae distally, also a lateral plumose seta. Endopod slightly curved with distal seta.

Maxilla (g): proximal endite reduced, unilobed, distal endite subequally bilobed. Endopod very short. Anterior lobe of scaphognathite large expanded toward tip, with fringe of about 20 setae. Posterior lobe narrow but almost as long as anterior lobe, with fringe of short setae the distal one curved and only slightly longer than others.

First maxilliped (h): proximal endite only slightly smaller than distal. Endopod short and with obscure divisions. Exopod long with 4 long apical setae. Epipod present.

Second maxilliped (i): endopod similar in shape to adult, distal segment wider than long. Exopod longer than endopod and with about 10 apical setae.

Third maxilliped (k): leg-like, longer than the first pereopod, with moderate exopod (no apical setae).

Pereopods: first $(\mathrm{I})$ and second $(\mathrm{m})$ only strongly chelate and with exopod. Carpus of second with about 5 divisions.

Pleopods (o): well-developed, appendix interna present in the second to fifth.

Telson (t): with sides parallel or slightly tapering, 2 pairs of lateral spines on distal half; terminally pair of equal spines at centre and an unequal pair at each corner.

Date of occurrence in plankton hauls: 10 August (Table 3). 


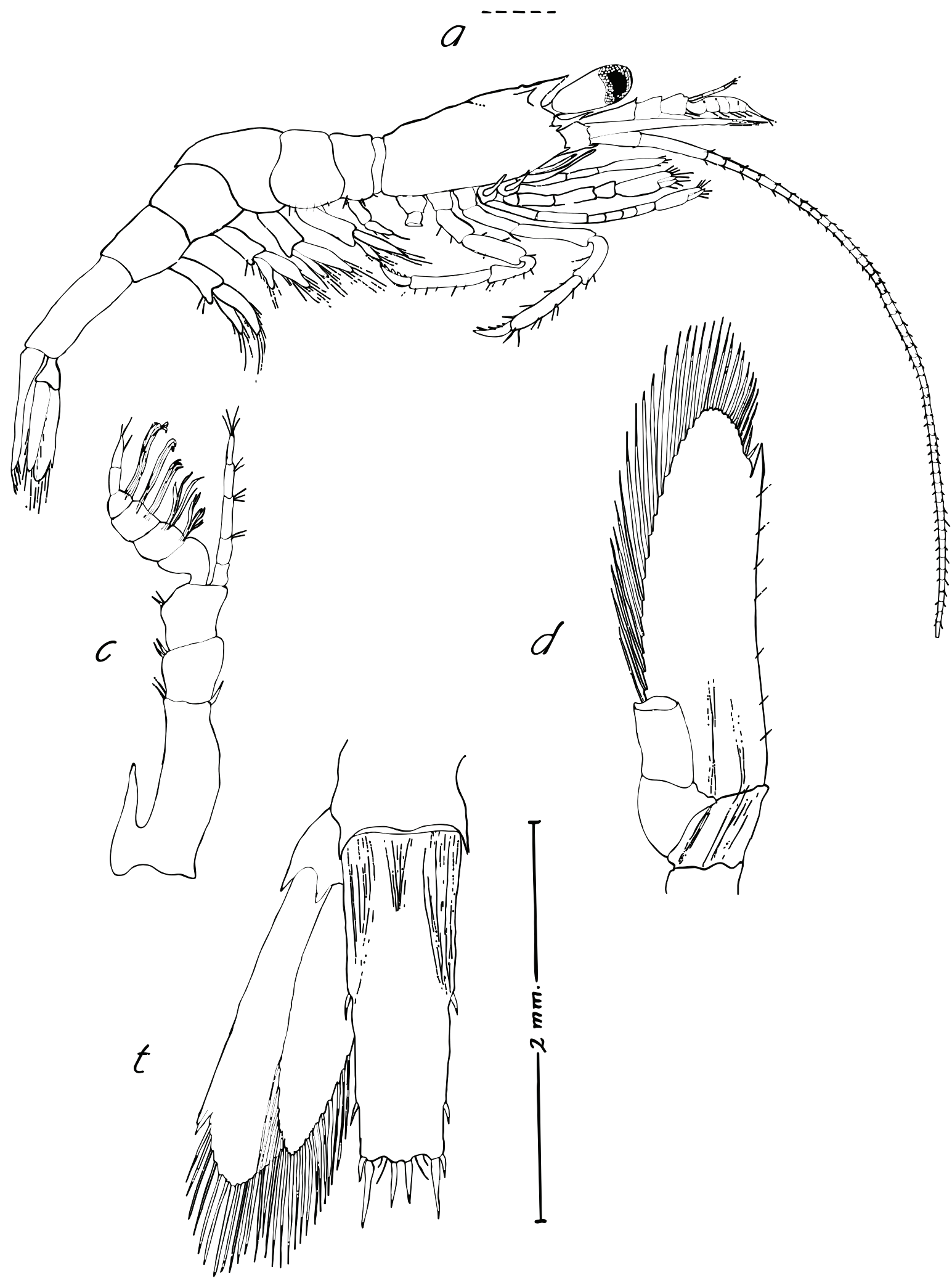

Fig. 38. Spirontocaris spinus, Megalopa: (a) whole animal from right side; (c) antennule; (d) antenna; (t) telson. Scale as indicated, broken line $=1 \mathrm{~mm}$. 

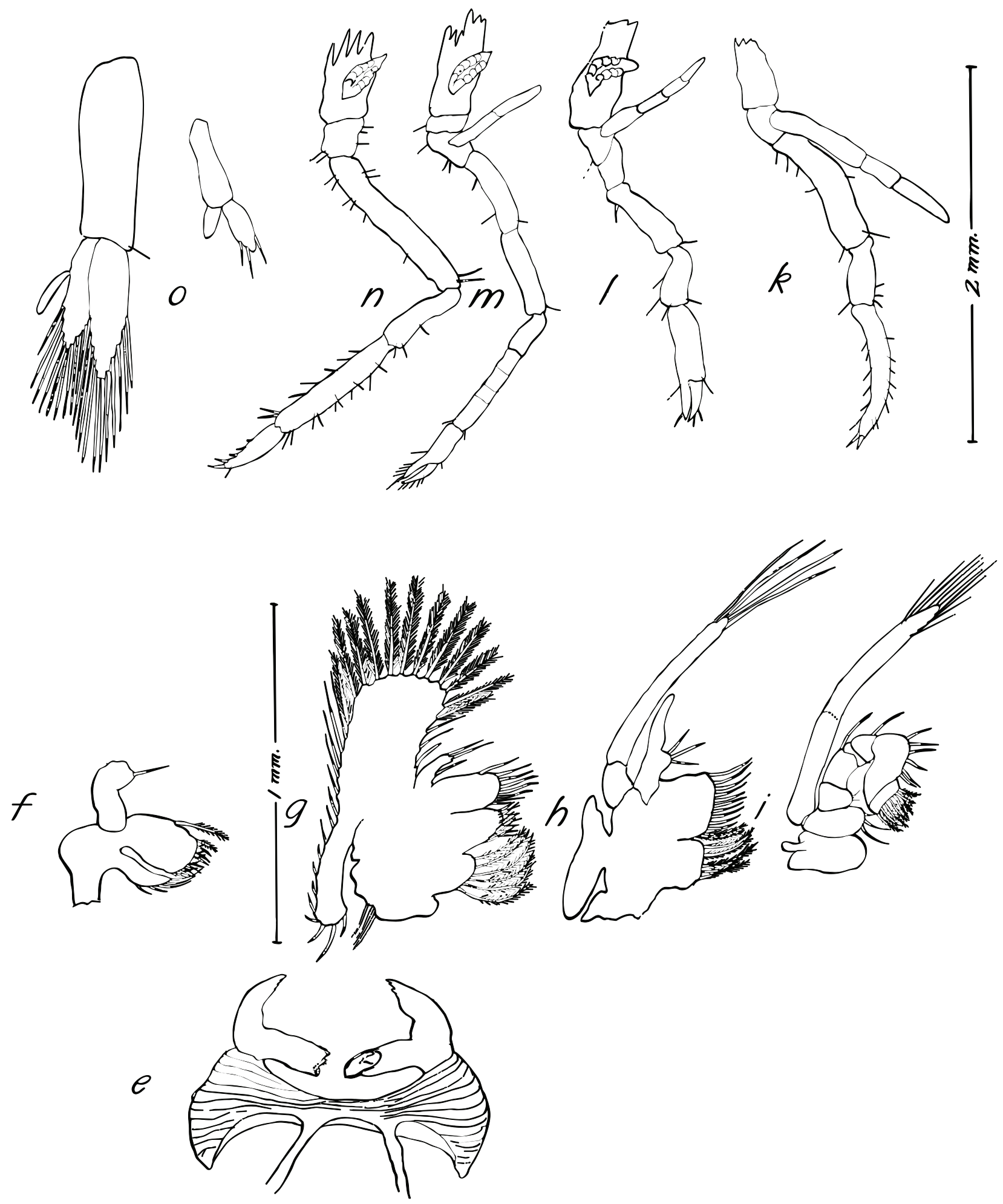

Fig. 39. Spirontocaris spinus, Megalopa: (e) mandibles; (f) maxillule; (g) maxilla; (h) first maxilliped; (i) second maxilliped; (k) third maxilliped; (I) first pereopod; (m) second pereopod; (n) third pereopod; (o) pleopods. Scales as indicated. 
Family PANDALIDAE Haworth, 1825

Gurney, 1942: 205-209, fig. 72, 73; key.

Haynes, 1985: 264.

The larvae of this family can be distinguished from other families of the Caridea present in Ungava Bay by the absence of dorsolateral spines on abdominal somites 4 and 5 , and the presence of exopods on the first to third pereopods, and eye-stalks tapered proximally. The larvae are small, and the abdomen appears long for the size of larva (Haynes, 1985).

\section{Genus Pandalus Leach, 1814}

Haynes, 1985: 266.

Larvae of this genus are usually small, abdomen long for size of larva, the first to third pereopods with exopods, early stages with small pereopods and undeveloped pleopods which exhibit delayed development. Antennal group in line with body rather than turned up as in Hippolytidae. The two species described here, Pandalus borealis and P. montagui can be separated as follows: $P$. borealis is the larger at each stage and has more setae on the antennal scale and on the scaphognathite in zoeal Stages II and III, and in Stage IV the telson of $P$. borealis has $5+5$ terminal setae, while in $P$. montagui there are $7+7$ including 2 lateral setae (Table 8 ).

\section{Pandalus borealis Krøyer, 1841}

$$
\text { Sars, 1900: PI. VII, fig. 4-11; }
$$

Wienberg, MS 1975: K :15, fig. p 19-21, 24.

Descriptions of larvae of Pandalus eous Makarov, 1935, from the Pacific (Berkeley, 1930; Haynes, $1979,1985)$ were thought to have been of Krøyer's $P$. borealis which is from the Atlantic, but sizes of various stages of larvae of the two species and characteristics of the adult shrimps indicate that they are different (Makarov, 1935; Wienberg, MS 1975; Squires, 1992). The Pacific P. eous has significantly larger larvae and more advanced development at each Stage than the Atlantic $P$. borealis; for example, the scaphognathite in Stage II has more developed lobes and more setae (Haynes, 1979) than in P. borealis observed in this study, and the rostrum in Stage $V$ is bifid (Haynes, 1979) while it is styliform in $P$. borealis (up to zoeal Stage VII, (Wienberg, MS 1975). Total lengths $(\mathrm{mm})$ at the different zoeal stages of $P$. borealis are as follows: I. --, II. 5.5-7.1, III. 7.0-7.5, IV. 8.08.8, Megalopa. 9.3.

Distribution in Ungava Bay: mostly on the east side of the Bay, west of Akpatok Island, Inuksulik, Koksoak River mouth, Whale River mouth, $10 \mathrm{~km}$ Northwest of Keglo Bay, Akpatok Island and Adlorilik (Fig. 1; Table 1). No. of specimens taken = 22 (Table 2).

\section{Description}

Stage I Zoea. The specimens collected were damaged and could not be used for drawings or description.

Dates of occurrence in plankton hauls: 11-27 July (Table 3).

Stage II Zoea. Total length 5.5-7.1 mm (Fig. 40, 41).

Carapace (a): with anterior median dorsal tubercle, antennal and pterygostomial spines. 


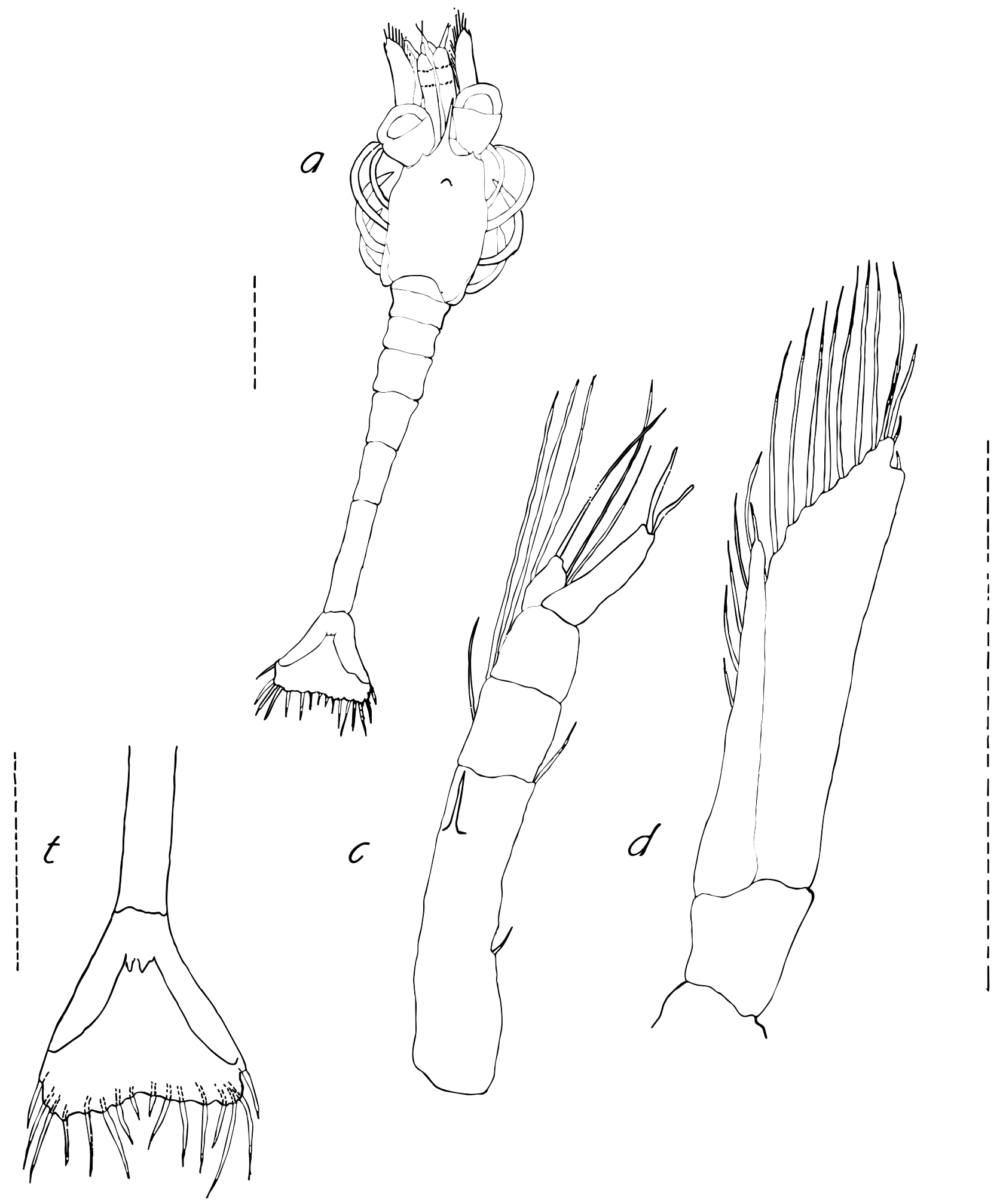

Fig. 40. Pandalus borealis, Stage II Zoea: (a) whole zoea in dorsal aspect; (c) antennule; (d) antenna; (t) telson. Broken line $=1 \mathrm{~mm}$. 


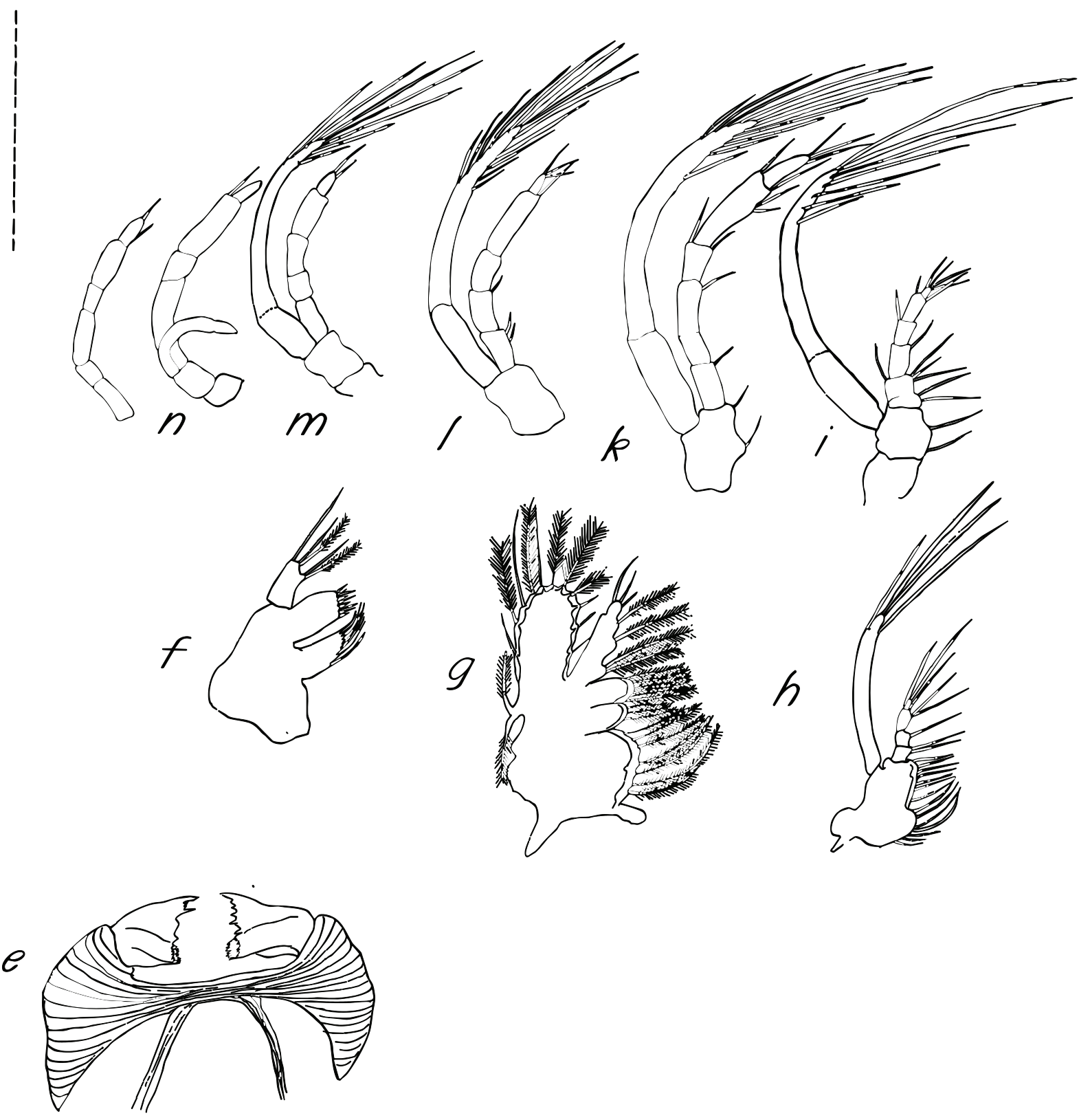

Fig. 41. Pandalus borealis, Stage II Zoea: (e) mandibles; (f) maxillule; (g) maxilla; (h) first maxilliped; (i) second maxilliped; (k) third maxilliped; (I) first pereopod; (m) second pereopod; (n) third pereopod. Broken line = $1 \mathrm{~mm}$.

Abdomen: without dorsolateral spines on somites 4 and 5.

Antennule (c): peduncle with 3 divisions, outer flagellum tapered with 2 apical aesthetes, inner short conical with long apical seta and surrounding long setae.

Antenna (d): scale slightly concave laterally, small distolateral spine and fan of about 14 long setae; flagellum shorter than scale, with 1 apical spine. 
Mandibles (e): right incisor with 1 tooth and a series of about 5 denticles between it and slender molar; left incisor with 2 long teeth separated by a few small ones and an uneven edge between it and molar.

Maxillule (f): proximal endite pointed with a few curved setae distally, distal endite somewhat larger and truncate with double row of stout setae distally. Endopod short, bifid, with 3 setae on distal branch and two on lateral.

Maxilla (g): proximal endite unilobate, distal bilobed subequal, with long fringing plumose setae. Endopod almost as long as anterior lobe of scaphognathite, the latter fringed with about 11 plumose setae; posterior lobe a short projection of corner of anterior lobe with 2 long plumose divergent setae.

First maxilliped (h): proximal endite rounded, fused with longer distal. Endopod short, with 4 divisions, much shorter than exopod, the latter with 4 distal setae. Indistinct epipod.

Second maxilliped (i): endopod with 5 divisions, much shorter than exopod, the latter with 7 apical setae.

Third maxilliped (k): with 5 divisions almost as long as exopod, the latter with about 10 apical setae.

Pereopods: first $(I)$, second $(n)$ and third $(m)$ with exopods, fourth and fifth simple.

Pleopods: biramous buds.

Telson (t): with $8+8$ unequal setae, the centre ones smallest.

Dates of occurrence in plankton hauls: 14-27 July (Table 3).

Stage III Zoea. Total length 6.5-7.5 mm (Fig. 42, 43).

Carapace (a): with two median teeth near base of rostrum, a supraorbital and pterygostomial spine. Rostrum long slender pointed, reaching cornea but not beyond the eye. Eyes large, stalk tapered toward base.

Abdomen: without dorsolateral spines on somites 4 and 5.

Antennule (c): first article longer than other two; outer flagellum tapered with 3 aesthetes distally, inner flagellum not as long, slender, indistinctly annulate, surrounded by long setae.

Antenna $(d)$ : scale with distolateral spine shorter than lamella, the latter with fan of about 16 long setae; flagellum slightly longer than scale.

Mandibles (e): right incisor with 1 tooth and 2 denticles between it and molar; left incisor 4 small teeth and about 3 denticles between it and molar.

Maxillule (f): proximal endite slender and pointed as in adult with curved setae, distal endite about as long with distal rows of stout setae. Endopod bifid with 2 distal and 2 lateral setae.

Maxilla (g): proximal endite unilobate, distal endite subequally bilobed, all with long curved setae. Endopod short. Anterior lobe of scaphognathite rounded distally and with fringe of about 15 long plumose setae, posterior lobe merely a projection of outer posterior corner with 2 setae, one directed forward and the other backward. 


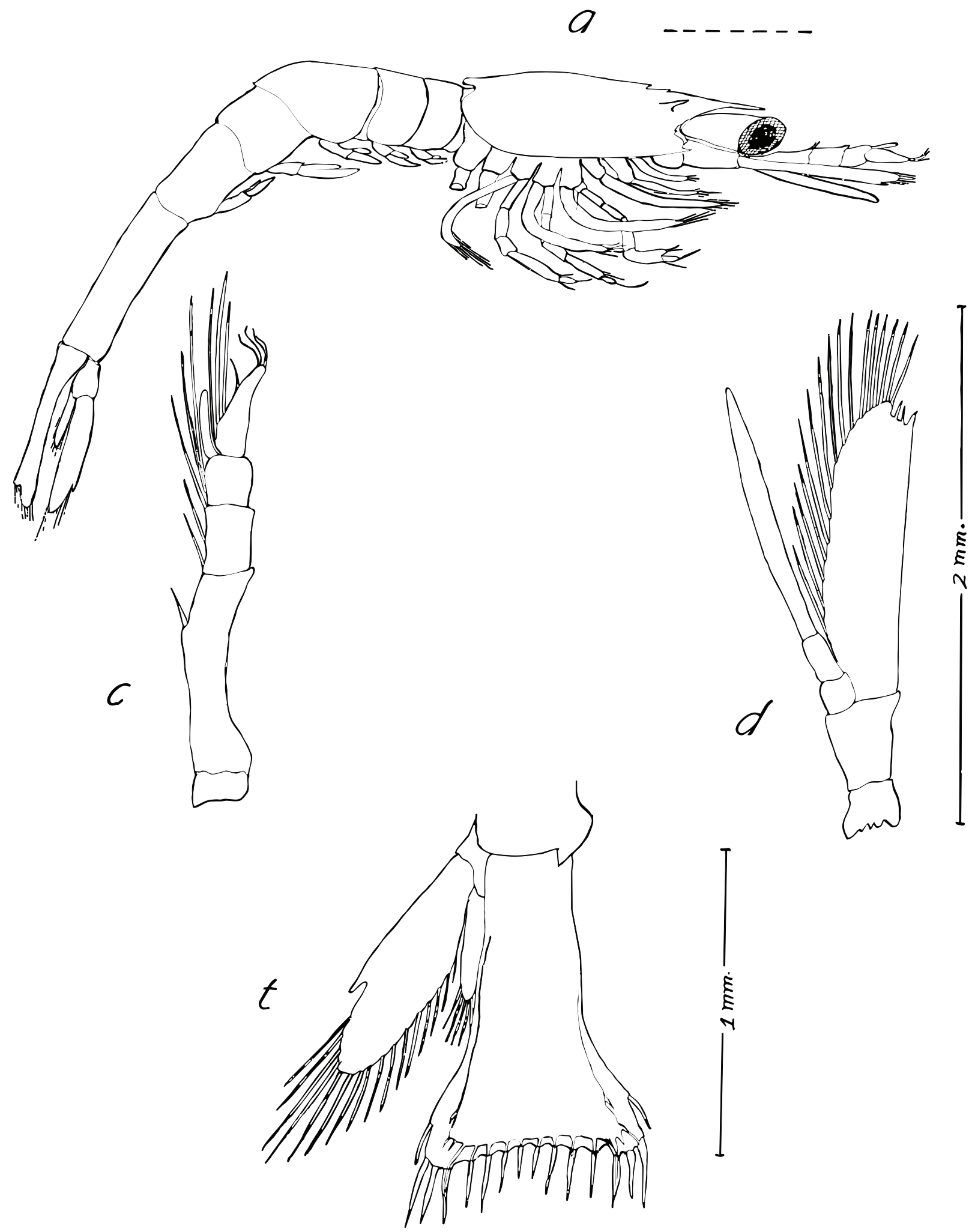

Fig. 42. Pandalus borealis, Stage III Zoea: (a) whole zoea from right side; (c) antennule; (d) antenna; (t) telson. Scales as indicated, broken line $=1 \mathrm{~mm}$. 

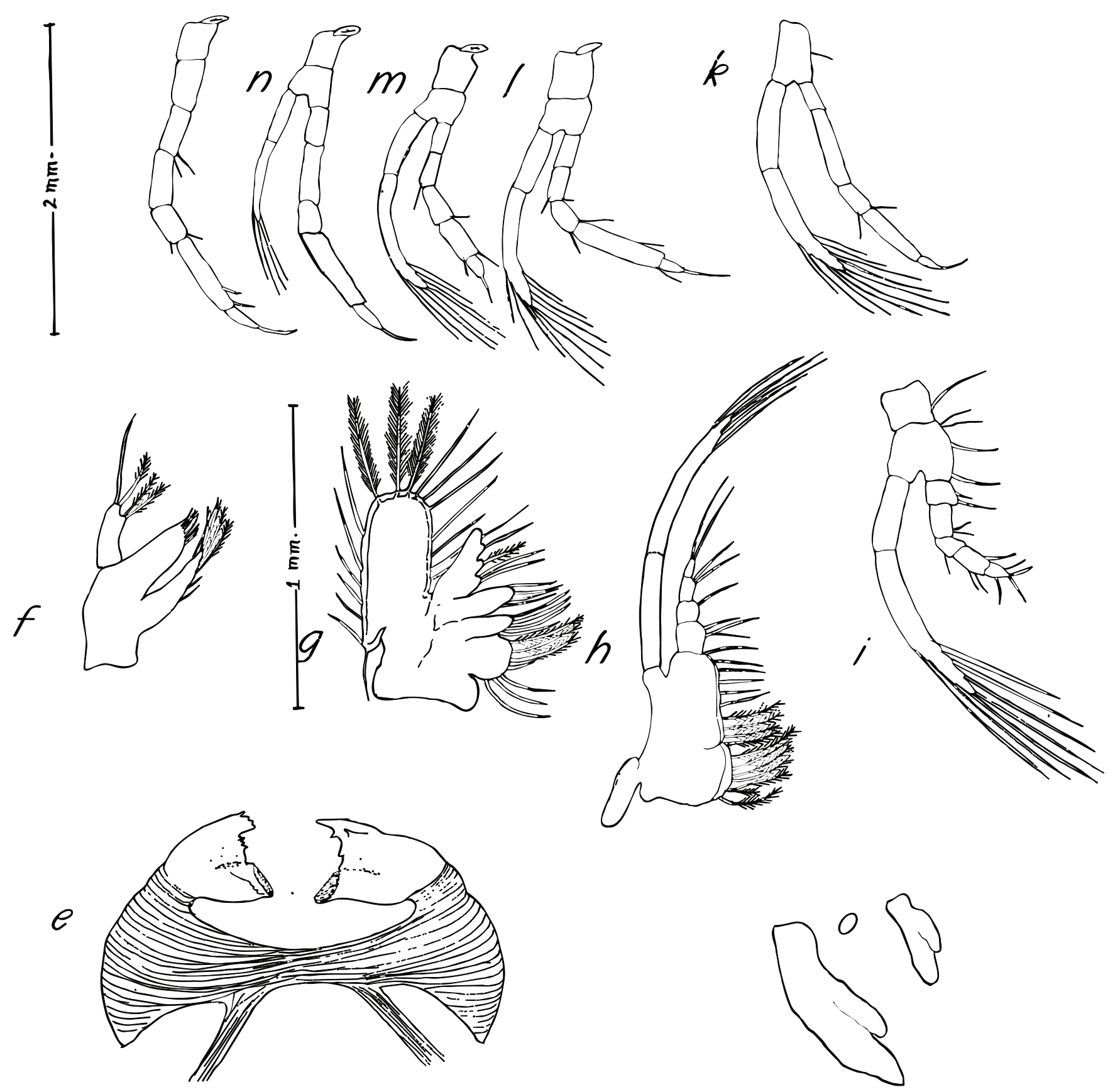

Fig. 43. Pandalus borealis, Stage III Zoea: (e) mandibles; (f) maxillule; (g) maxilla; (h) first maxilliped; (i) second maxilliped; (k) third maxilliped; (I) first pereopod; (m) second pereopod; (n) third pereopod; (o) pleopods. Scales as indicated.

First maxilliped (h): proximal endite shorter than distal endite, both thickened at inner edge and with fringe of long curved setae. Endopod short with 4 divisions, exopod much longer with distal 5 long plumose setae.

Second maxilliped (i): endopod with 5 divisions much shorter than exopod, the latter with 7 distal setae.

Third maxilliped (k): leglike, endopod slightly exceeding exopod, the latter with about 10 apical setae. 
Pereopods: first (I), second $(m)$ and third $(n)$ with exopods, dactyls with sharp distal spine, fourth and fifth slightly longer than others.

Pleopods: biramous.

Telson (t): still expanded distally with $7+7$ setae terminally and a pair of spines laterally.

Dates of occurrence in plankton hauls: 20 July-27 August (Table 3).

Stage IV Zoea. Total length 8.0-8.8 mm (Fig. 44, 45).

Carapace (a): carapace to abdomen length 1: 3.7. A small supraorbital and strong pterygostomial spine present. Rostrum long, attenuate with about 8 spines above, none on anterior half, tip not quite reaching distal first article of antennule.

Abdomen: without dorsolateral spine on somites 4 and 5 .

Antennule (c): first article much longer than second and third combined, with rounded stylocerite on proximal third and a strong spine at halfway below. Outer flagellum conical with 3 lateral and a terminal group of aesthetes, inner flagellum longer but slender with 2 unequal spines distally.

Antenna (d): scale slender, distolateral spine exceeding lamella, the latter with fan of numerous long setae. Flagellum annulate, about twice length of scale.

Mandibles (e): right incisor with a long tooth with one accessory and 3 denticles on thin edge between it and molar; left incisor with long tooth and 3 accessories and 2 denticles between it and molar.

Maxillule (f): proximal endite pointed and with fringe of curved setae, distal endite slightly larger with distal rows of stout setae; endopod appearing bifid with 3 distal and 2 lateral setae.

Maxilla (g): proximal endite unequally bilobed with one lobe very small; distal endite with proximal lobe smaller than distal. Endopod only about half as long as rounded anterior lobe of scaphognathite, the latter with fringe of about 15 long plumose setae and a few short setae outside, posterior lobe only a narrow corner projection with long terminal spine.

First maxilliped (h): proximal endite short, distal about twice as long. Endopod of 4 divisions about half as long as slender exopod, the latter with 4 long apical setae. Large epipod.

Second maxilliped (i): endopod of 5 divisions about half as long as slender exopod, the latter with 10 long apical setae. Small epipod.

Third maxilliped $(\mathrm{k})$ : leglike with 5 divisions the distal longest and with a curved distal spine. Exopod long with about 8 apical setae.

Pereopods: first (I) and second $(\mathrm{m})$ chelate, dactyl with distal curved spine, also both with exopod longer than endopod. The third $(n)$ non-chelate and longer than first and second but with short exopod. The fourth (n') and fifth as long as third but without exopods.

Pleopods (o): biramous, appendix interna present in 2-5.

Telson (t): with $5+5$ terminal setae, smallest pair at centre, also small seta at each side.

Dates of occurrence: 3-25 August (Table 3). 

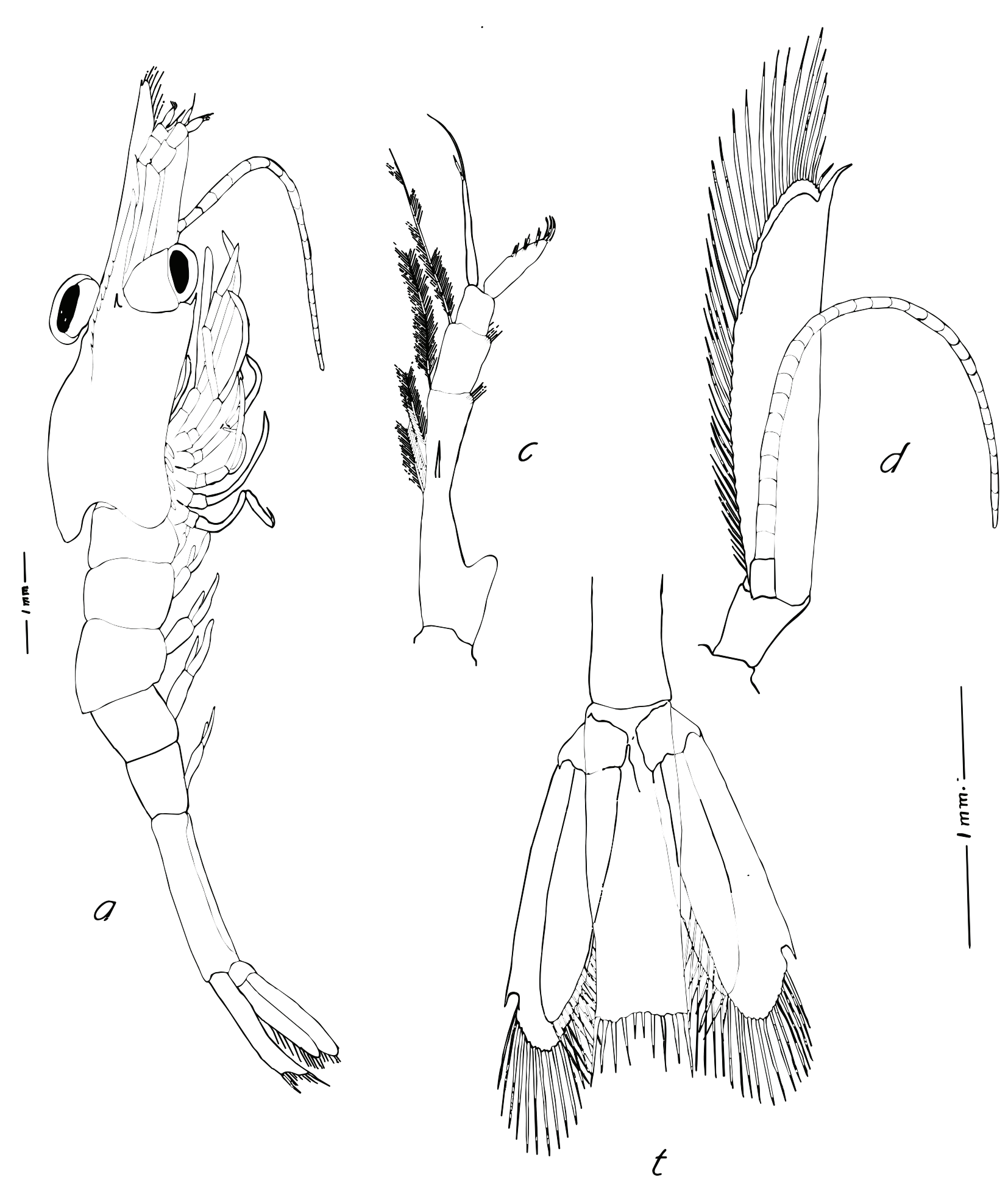

Fig. 44. Pandalus borealis, Stage IV Zoea: (a) whole zoea from right side; (t) telson; (c) antennule; (d) antenna. Scales as indicated. 


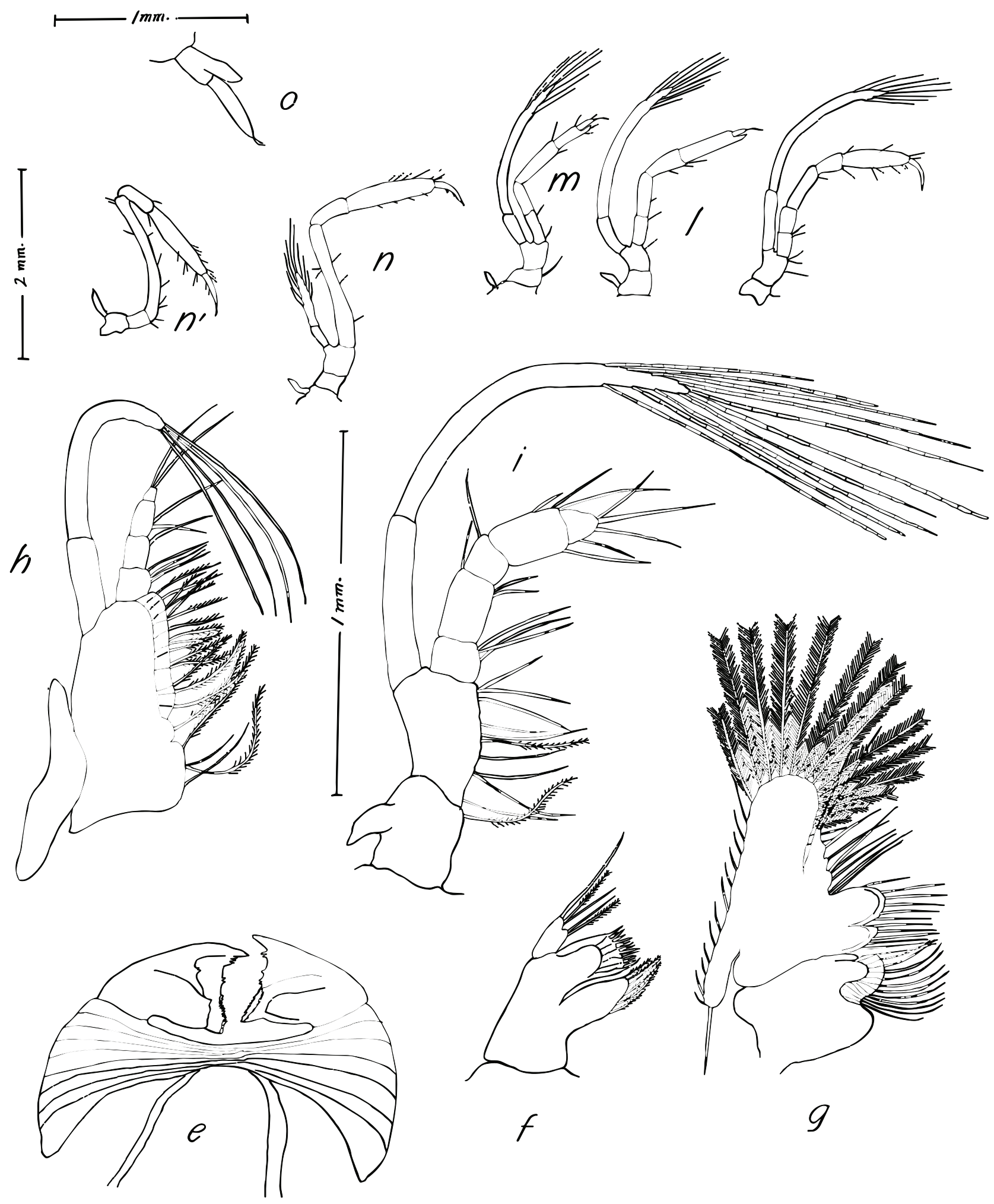

Fig. 45. Pandalus borealis, Stage IV Zoea: (e) mandibles; (f) maxillule; (g) maxilla; (h) first maxilliped; (i) second maxilliped; (k) third maxilliped; (I) first pereopod; (m) second pereopod; (n) third pereopod; (n') fourth pereopod; (o) pleopod. Scales as indicated. 
Pandalus montagui Leach, 1814

Sars, 1900: 23-26, PI. VIII, fig. 1-5.

Lebour, 1940: 241, fig. 2.

Pike and Williamson, 1964: 276-280, fig. 4.

Larvae of this species are considerably smaller and also less well-developed at each Stage than those of Pandalus borealis. In particular, at early stages in this species the pereopods are poorly developed and the pleopods merely buds (Table 8). Total lengths $(\mathrm{mm})$ at the different zoeal Stages were as follows: I. 3.0-3.7, II. 3.7-5.3, III. 4.4-5.5, IV. 4.9-6.0.

Distribution in Ungava Bay: mostly along east coast of the Bay but also at Tuvalik, Inuksulik (1), Leaf Bay, Koksoak River, Beacon Island, Keglo Bay, Adlorilik, Forbes Sound, near Port Burwell and at Button Islands (Fig. 1; Table 1). No. of specimens taken = 69 (Table 2).

\section{Description}

Stage I Zoea. Total length $3.3 \mathrm{~mm}$ (Fig. 46, 47).

Carapace (a): with anterior tubercle only and three anteroventral spinules. Rostrum short, not exceeding eyes. Eyes large, stalks attached to front of carapace.

Abdomen: smooth, without dorsolateral spines on somites.

Antennule (c): inner flagellum a long plumose seta only; outer flagellum conical with 2 aesthetes and a small seta apically plus one seta at base.

Antenna (d): endopod (flagellum) less than half length of scale, the latter segmented at tip and with a fringe of about 7 plumose setae plus 2 short distolateral spines.

Mandibles (e): slightly dissimilar; the right incisor with 2 teeth and a thin denticle followed by thin edge to stout molar, left with longer pointed incisor with 2 teeth followed by a low tooth and another near the molar.

Maxillule (f): proximal (coxal) endite with 3 long curved and 2 short spinous setae; distal (basal) endite slightly larger and with short rows of stout setae. Endopod bifid with 3 apical and 2 lateral setae.

Maxilla (g): proximal endite with unequal lobes, distal endite with equal lobes. Endopod almost as long as anterior lobe of scaphognathite, the latter with only 3 plumose setae, plus the posterior lobe a lateral projection proximally with 2 divergent setae.

First maxilliped (h): endites unequal, fused. Endopod with 4 divisions and shorter than exopod, the latter with 4 long apical setae.

Second maxilliped (i): short endopod with 4 divisions, long exopod with 8 long apical setae.

Third maxilliped $(\mathrm{k})$ : endopod with 5 divisions, almost as long as exopod which has 9 apical (natant) setae.

Pereopods: first (I) small, bud-like, with exopod. The second (m) and third (n) somewhat smaller than the first, also with exopod. The fourth and fifth very small and without exopods. 


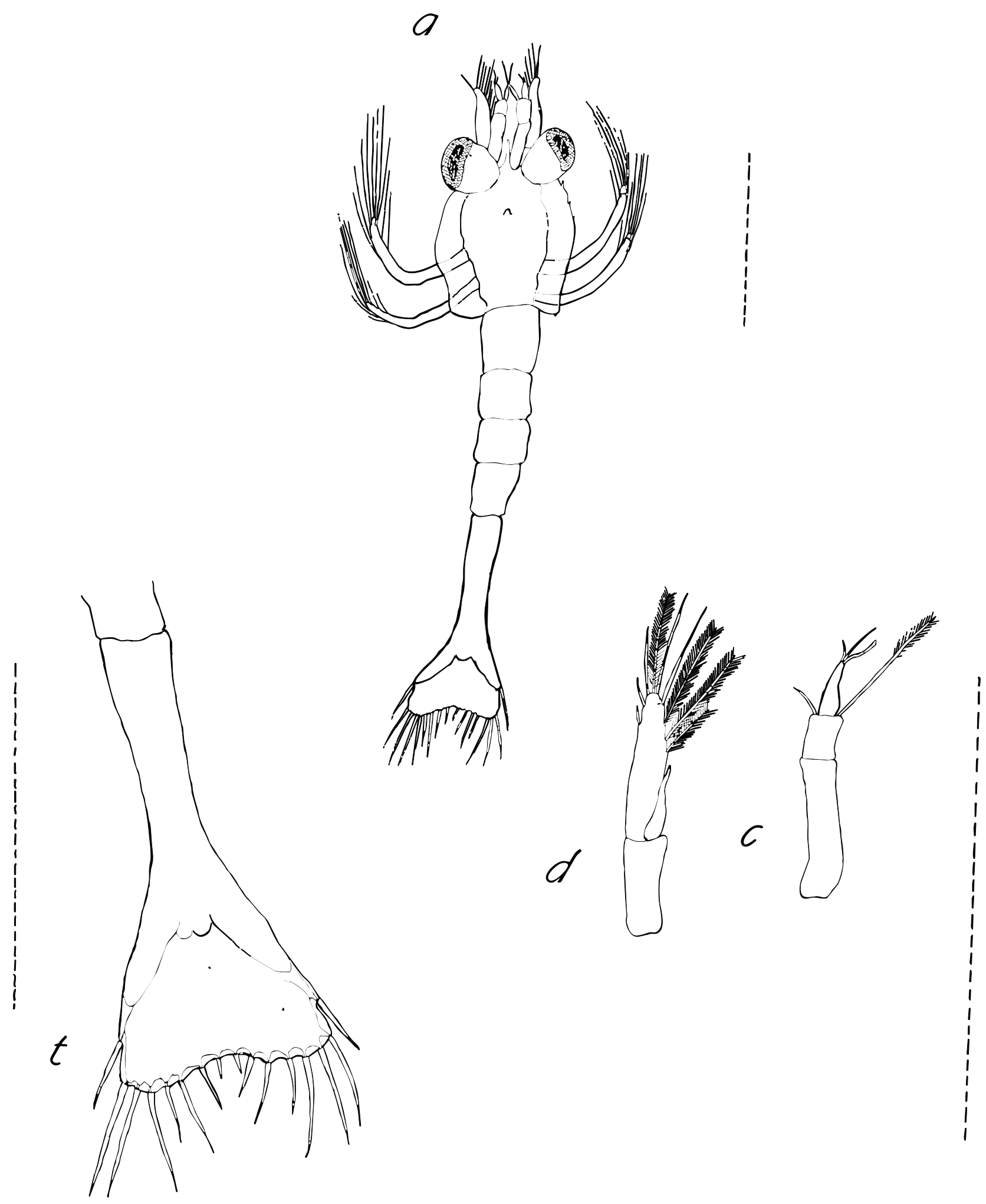

Fig. 46. Pandalus montagui, Stage I Zoea: (a) whole zoea in dorsal aspect; (c) antennule; (d) antenna; (t) telson. Broken line $=1 \mathrm{~mm}$. 
3<smiles>C1CCCC1</smiles>
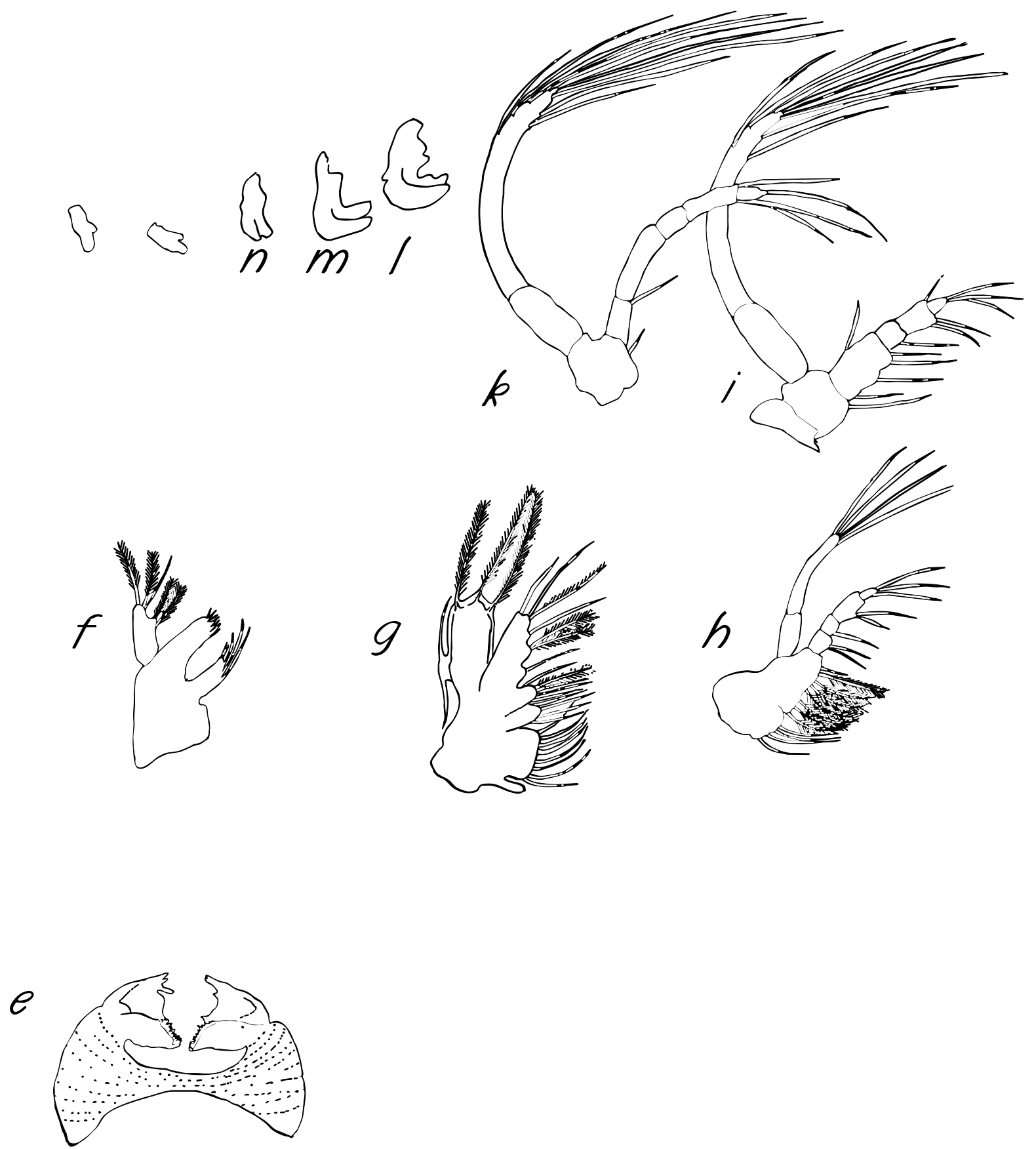

Fig. 47. Pandalus montagui, Stage I Zoea: (e) mandibles; (f) maxillule; (g) maxilla; (h) first maxilliped; (i) second maxilliped; (k) third maxilliped; (I) first pereopod; $(\mathbf{m})$ second pereopod; $(\mathbf{n})$ third pereopod. Broken line $=1$ $\mathrm{mm}$.

Pleopods: not present.

Telson (t): with $8+8$ terminal setae, the middle pair very short.

Dates of occurrence in plankton hauls: 24 June to 20 July (Table 3). 
Stage II Zoea. Total length $4.3 \mathrm{~mm}$ (Fig. 48, 49).

Carapace (a): with small anterior median tubercle, no supraorbital spine, a strong pterygostomial spine and 1 or 2 anteroventral denticles. Rostrum short reaching about half the first article of peduncle of antennule.

Abdomen: smooth, without dorsolateral spines on somites 4 and 5 .

Antennule (c): peduncle with 2 divisions, outer flagellum conical with 3 apical aesthetes, inner flagellum a long plumose seta only.

Antenna $(\mathrm{d})$ : scale rounded distally with a fan of about 6 long setae; flagellum pointed, about two-thirds as long as scale.

Mandibles (e): right incisor with 2 small teeth and 2 denticles between it and molar; left with 3 uneven teeth and no denticles.

Maxillule (f): proximal endite pointed with a few curved setae, shorter than distal endite, the latter with rows of short stout setae distally. Endopod bifid with 3 distal and 1 lateral setae.

Maxilla (g): proximal endite unilobate, squarish; distal endite equally bilobed. Endopod stout, longer than anterior lobe of scaphognathite, the latter with only 3 long distal setae, the posterior lobe a lateral projection with 2 setae one directed backward and the other forward.

First maxilliped (h): proximal endite rounded, not as long as distal. Endopod with 4 divisions, shorter than exopod, the latter with 4 apical setae.

Second maxilliped (i): endopod with about 5 divisions, much shorter than exopod, the latter with about 8 long apical setae.

Third maxilliped (k): endopod with 5 divisions, almost as long as exopod, the latter with about 10 apical long setae.

Pereopods: buds only but first (I), second (m) and third (n) biramous.

Pleopods (o): buds only.

Telson (t): $8+8$ unequal terminal setae, one pair of which are lateral.

Dates of occurrence in plankton hauls: 3 July-26 August (Table 3).

Stage III Zoea. Total length 4.9 mm (Fig. 50, 51).

Carapace (a): with anterior median tubercle, also pterygostomial and supraorbital spine and two anteroventral denticles. Rostrum short reaching only half eye-stalk. Eyes large, stalks slightly tapered proximally.

Abdomen: smooth without dorsolateral spines on somites 4 and 5.

Antennule (c): with only 2 articles, the first very long; outer flagellum conical with 2 apical aesthetes, inner still only a long plumose seta but with swollen base and 2 long setae lateral to it.

Antenna $(\mathrm{d})$ : scale with distolateral spine slightly exceeding blade and fan of about 10 long setae, flagellum not quite half as long as scale and with apical spine. 


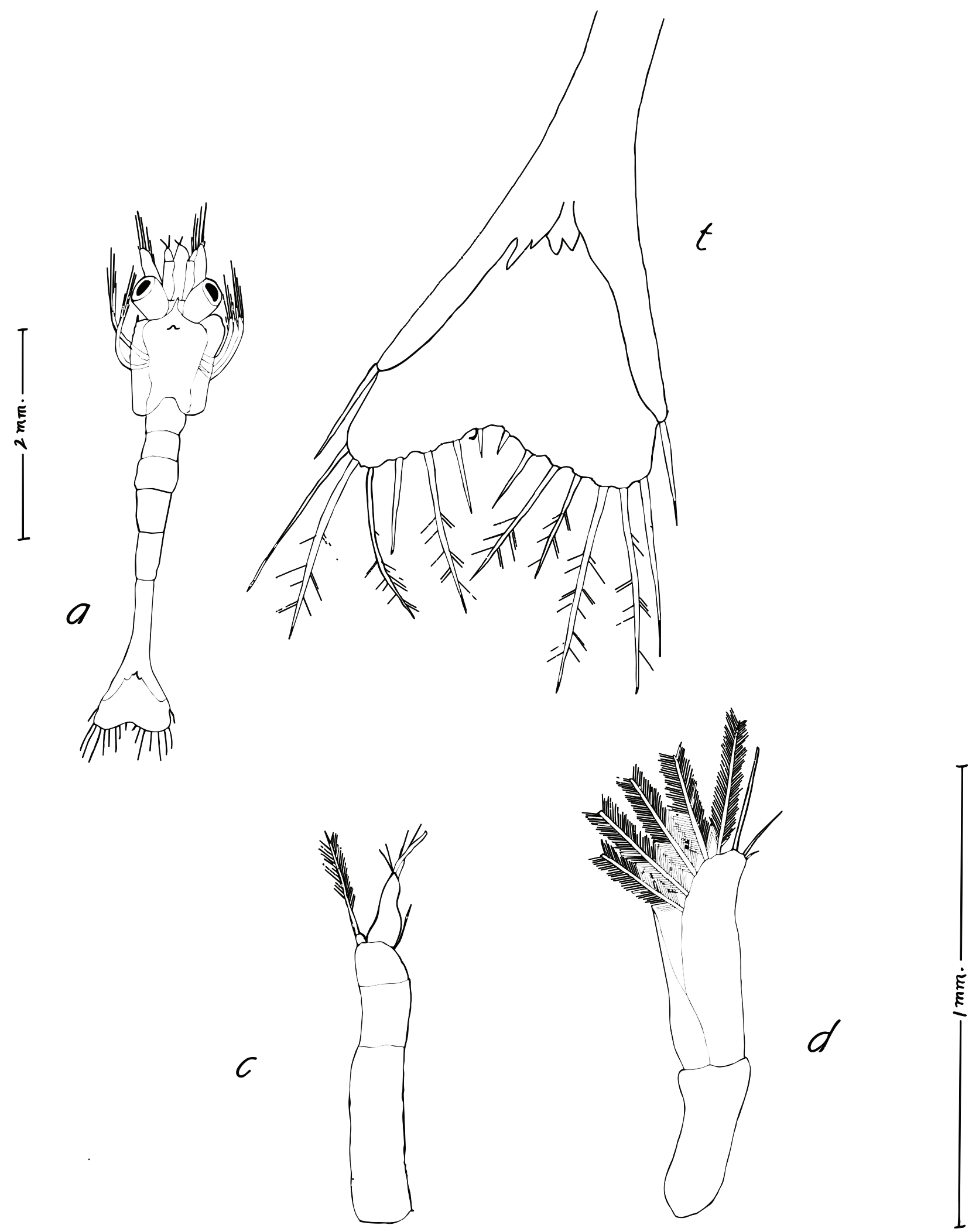

Fig. 48. Pandalus montagui, Stage II Zoea: (a) whole zoea in dorsal aspect; (t) telson; (c) antennule; (d) antenna. Scales as indicated. 


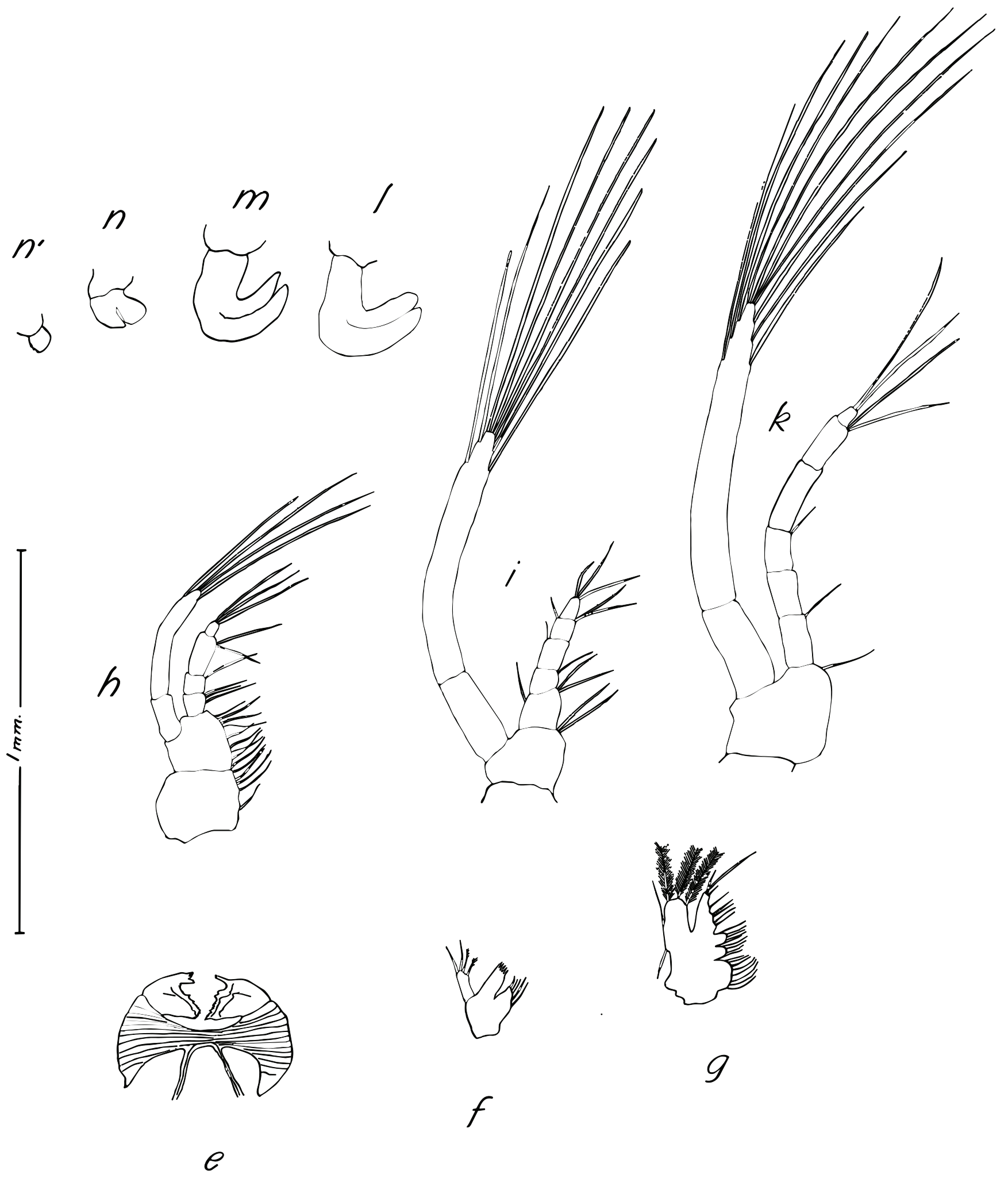

Fig. 49. Pandalus montagui, Stage II Zoea: (e) mandibles; (f) maxillule; (g) maxilla; (h) first maxilliped; (i) second maxilliped; (k) third maxilliped; (I) first pereopod; (m) second pereopod; (n) third pereopod; (n') fourth pereopod. Solid line $=1 \mathrm{~mm}$. 


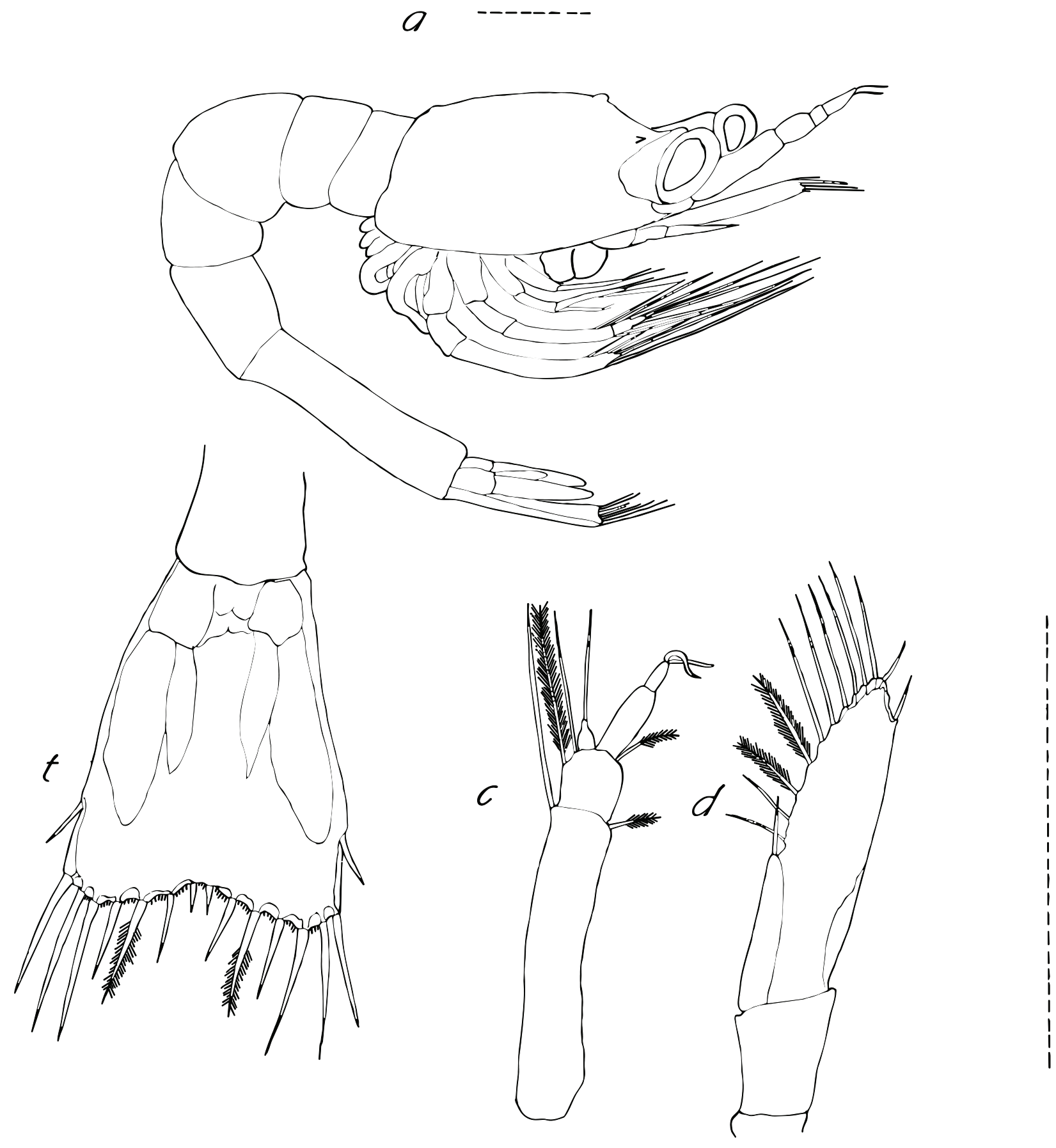

Fig. 50. Pandalus montagui, Stage III Zoea: (a) whole zoea from right side; (c) antennule; (d) antenna; (t) telson. Broken line $=1 \mathrm{~mm}$.

Mandibles (e): right incisor with sharp tooth and 2 accessory teeth followed by 3 denticles between it and molar. Left incisor with 2 large teeth and uneven edge between it and molar.

Maxillule (f): proximal endite pointed and with curved setae, distal stouter and longer with truncate edge with rows of short setae. Endopod bifid with 3 apical and 2 lateral setae. 


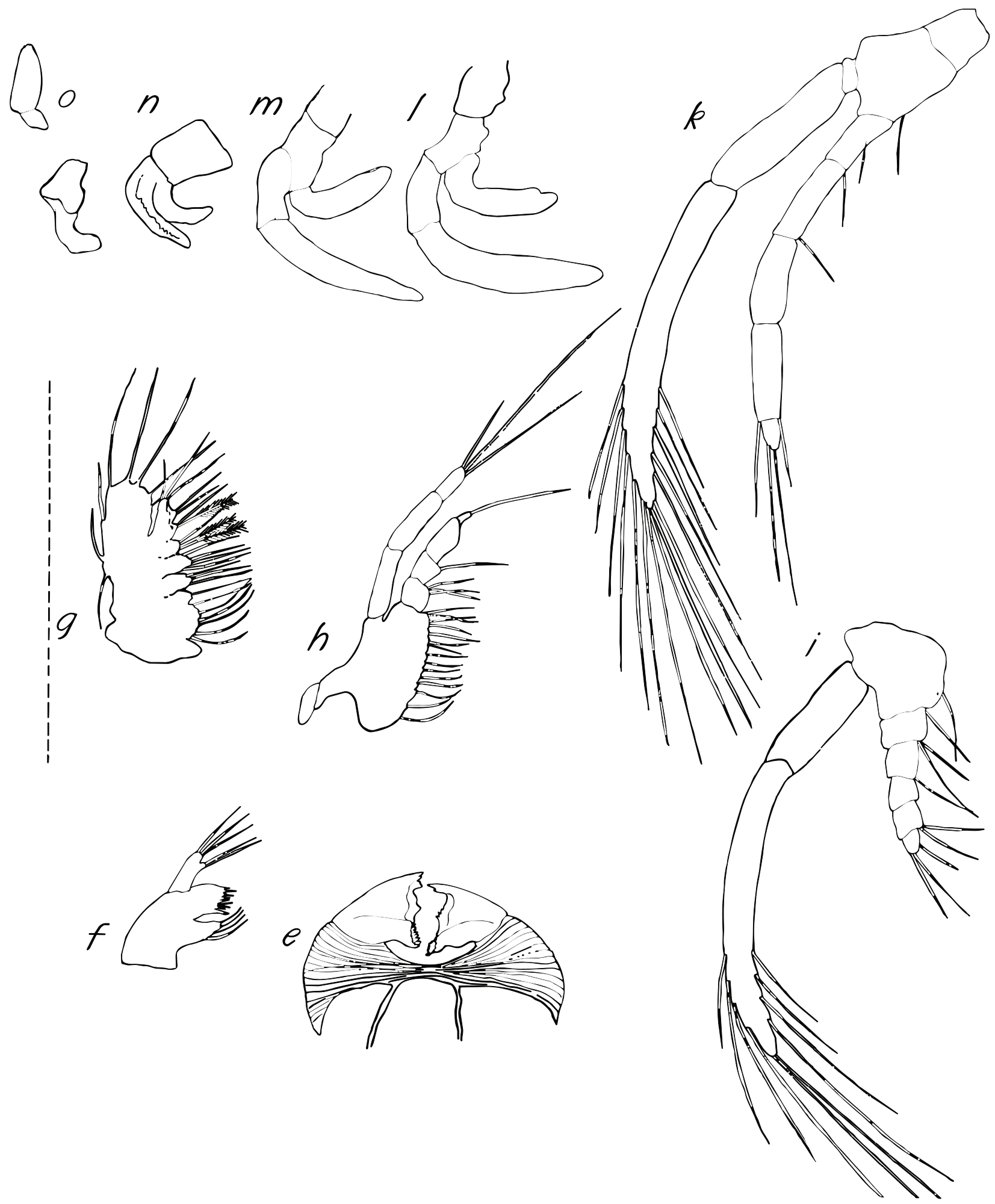

Fig. 51. Pandalus montagui, Stage III Zoea: (e) mandibles; (f) maxillule; (g) maxilla; (h) first maxilliped; (i) second maxilliped; (k) third maxilliped; (I) first pereopod; (m) second pereopod; (n) third pereopod; (o) pleopod. Broken line $=1 \mathrm{~mm}$. 
Maxilla (g): proximal endite unequally bilobed, distal subequally bilobed. Endopod stoutish almost as long as rounded anterior lobe of scaphognathite, the latter with 6 long plumose setae, posterior lobe a proximo-lateral extension with 2 long spinous setae 1 directed backward and the other forward.

First maxilliped (h): proximal endite shorter than distal, endopod of 4 divisions shorter than exopod, the latter with 3 apical setae. Small epipod.

Second maxilliped (i): endopod of 5 divisions much shorter than exopod, the latter with about 10 apical setae.

Third maxilliped (k): endopod of 5 divisions, dactyl with long curved spine distally. Long exopod with about 15 apical setae.

Pereopods: first $(I)$, second $(m)$ and third $(n)$ biramous buds, others uniramous.

Pleopods (o): buds only.

Telson (t): with $8+8$ unequal terminal setae one pair of which is lateral; short branch of uropod with two apical setae.

Dates of occurrence in plankton hauls: 17-28 August (Table 3).

Stage IV Zoea. Total length 5.5 mm (Fig. 52, 53).

Carapace (a): with median tubercle near base of rostrum, a supraorbital and strong pterygostomial spine and no anteroventral denticles. Rostrum almost as long as eye-stalk.

Abdomen: smooth with no dorsolateral spines on somites 4 and 5 .

Antennule (c): first article longer than other two combined; outer flagellum stout not annulated with 5 aesthetes apically, inner flagellum conical, shorter than outer, with a long apical spine.

Antenna (d): scale with distolateral spine about even with blade, the latter with fan of about 22 long setae. Flagellum almost as long as scale and with 1 spine at tip.

Mandibles (e): right incisor with 1 tooth plus accessory and 2 denticles between it and molar; left incisor with 3 teeth and 2 denticles between it and molar.

Maxillule (f): proximal endite pointed and with curved setae, shorter than stout distal endite with rows of short spines at truncate tip. Endopod bifid with 3 setae distally and 2 laterally.

Maxilla (g): proximal endite unequally bilobed, distal subequally bilobed; endopod stout shorter than anterior lobe of scaphognathite, the latter with fringe of about 20 long setae; posterior lobe narrow, half as long as anterior lobe, with a long backward spine.

First maxilliped (h): endites fused, endopod of 4 divisions, shorter than exopod, the latter with 4 apical setae; bilobed epipod.

Second maxilliped (i): endopod of 5 divisions much shorter than exopod, the latter with about 11 apical setae.

Third maxilliped ( $\mathrm{k}$ ): endopod leglike, of 5 divisions, almost as long as exopod, the latter with about 13 apical setae. 


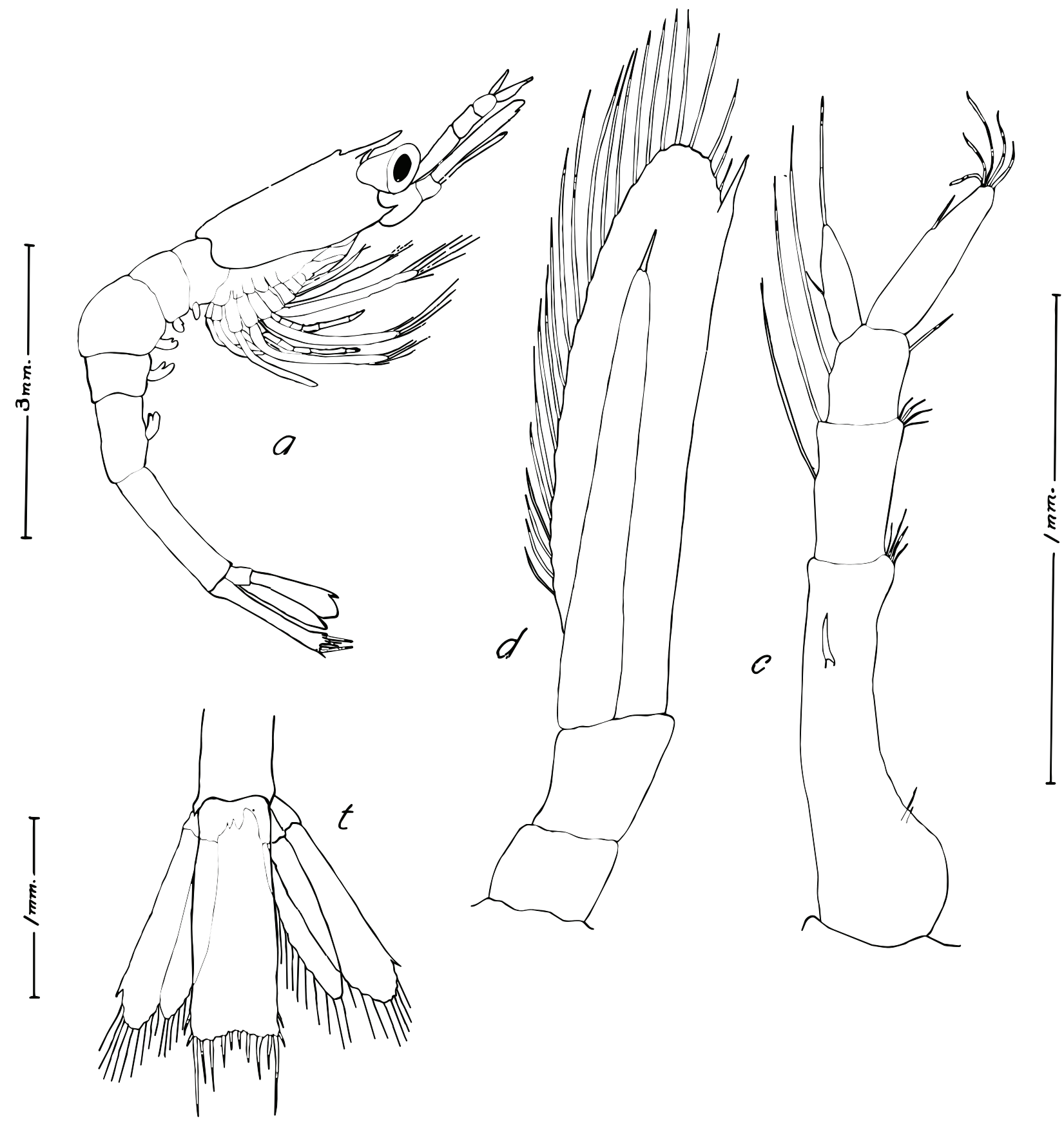

Fig. 52. Pandalus montagui, Stage IV Zoea: (a) whole zoea from right side; (t) telson; (c) antennule; (d) antenna; scales as indicated.

Pereopods: first (I), second $(\mathrm{m})$ and third $(\mathrm{n})$ with exopods, no evidence of chelae.

Pleopods (o): biramous.

Telson (t): with $7+7$ terminal setae two pairs of which are lateral.

Dates of occurrence in plankton hauls: 26-28 August (Table 3). 


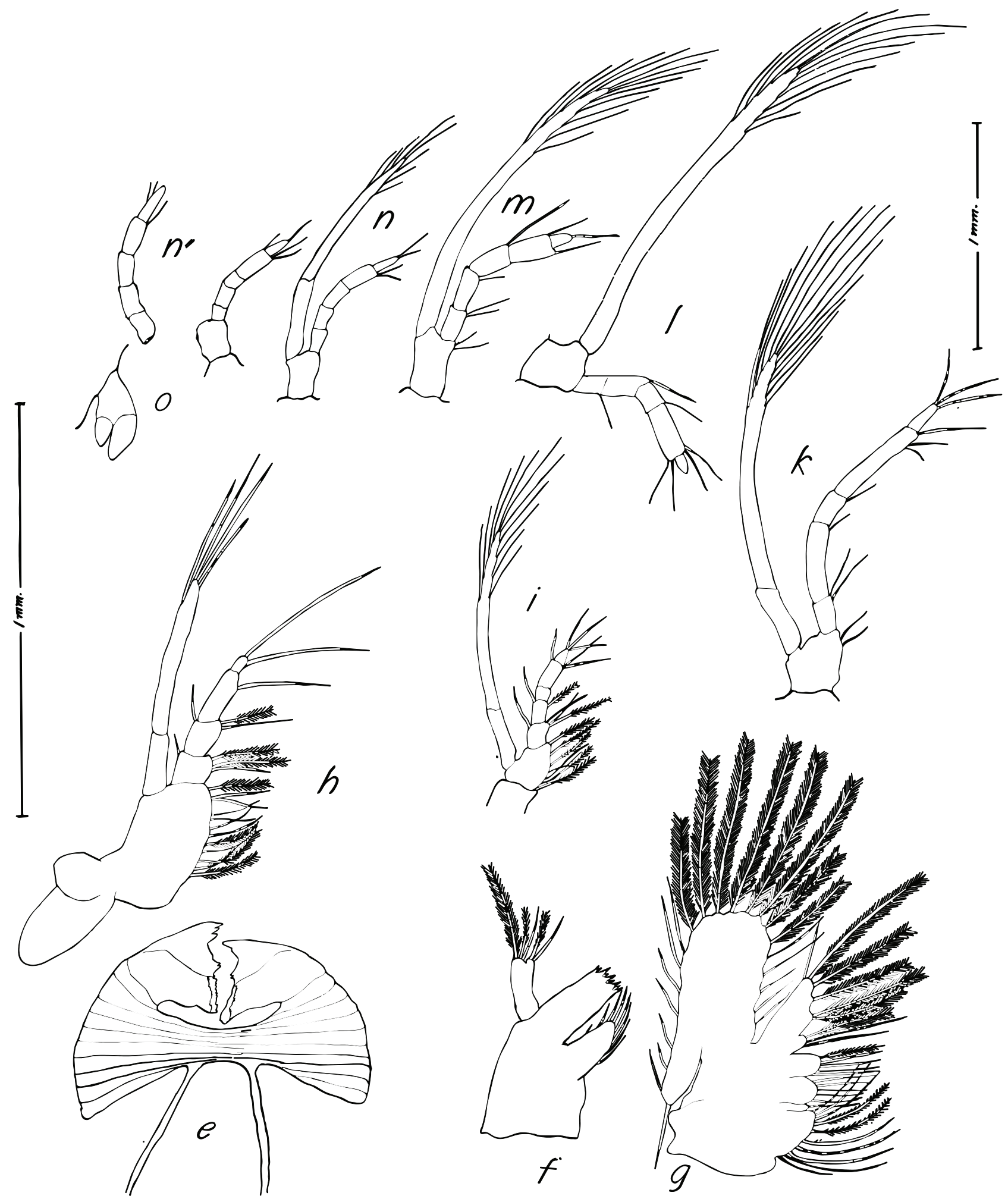

Fig. 53. Pandalus montagui, Stage IV Zoea: (e) mandibles; (f) maxillule; (g) maxilla; (h) first maxilliped; (i) second maxilliped; (k) third maxilliped; (I) first pereopod; (m) second pereopod; (n) third pereopod; (n') fifth pereopod; (o) pleopod. Scales as indicated. 


\section{Dichelopandalus bonnieri}

and

\section{Pandalus propinquus}

No specimens of these species were taken in the survey samples, however, descriptions available from published literature are given in Table 9.

Family CRANGONIDAE H. Milne-Edwards, 1837

Gurney, 1942: 220-222, fig. 83, 84.

Hart, 1971: 233, fig. 22, key.

Haynes, 1985: 280.

Makarov, 1966: 66.

This family is characterized by advanced larval forms with few stages, eye-stalks globose and almost touching, rostrum styliform, antennules with bases touching, even early stages with presubchelate first pereopod, and dorsolateral spines on abdominal somite 5. The endopod of pleopods are undeveloped. Larvae of two species were collected in Ungava Bay: Argis dentata and Sabinea septemcarinata. Larvae of Sclerocrangon boreas cling to the adult and are not taken in the plankton.

Genus Argis Krøyer, 1942

Haynes, 1985: 280.

Rostrum styliform in zoeal Stages I and II; exopod rudimentary on the first pereopod; dorsolateral spine on somite 5 (lost in megalopa). Abbreviated development (Makarov, 1966).

Argis dentata Rathbun, 1902

Squires, 1965: 69-82, fig. 1-7

This species is readily recognizable in this Bay because of its large size compared with larvae of other species (only Sabinea is larger) (Table 10). Appendages are well-developed even at zoeal Stage I and the subchelate form of the first pereopods is recognizable although probably not functional at that stage. Dorsolateral spines are present only on abdominal somite 5 . Total lengths $(\mathrm{mm})$ at the different zoeal Stages are as follows: I. 7.7-9.6, II. 9.5-10.4, Megalopa. 12.0.

Distribution in Ungava Bay: larvae were taken at many plankton stations throughout the Bay including Imilik, Hopes Advance Bay, Inuksulik (1), Leaf Bay, Koksoak River mouth, Beacon Island, Keglo Bay, Adlorilik and near Port Burwell (Fig. 1; Table 1). No. of specimens taken $=1793$ (Table 2).

\section{Description}

Stage I Zoea. Total lengths 7.2-9.5 mm (Fig. 54, 55).

These descriptions are from Squires (1965, fig. 1 and 2). 


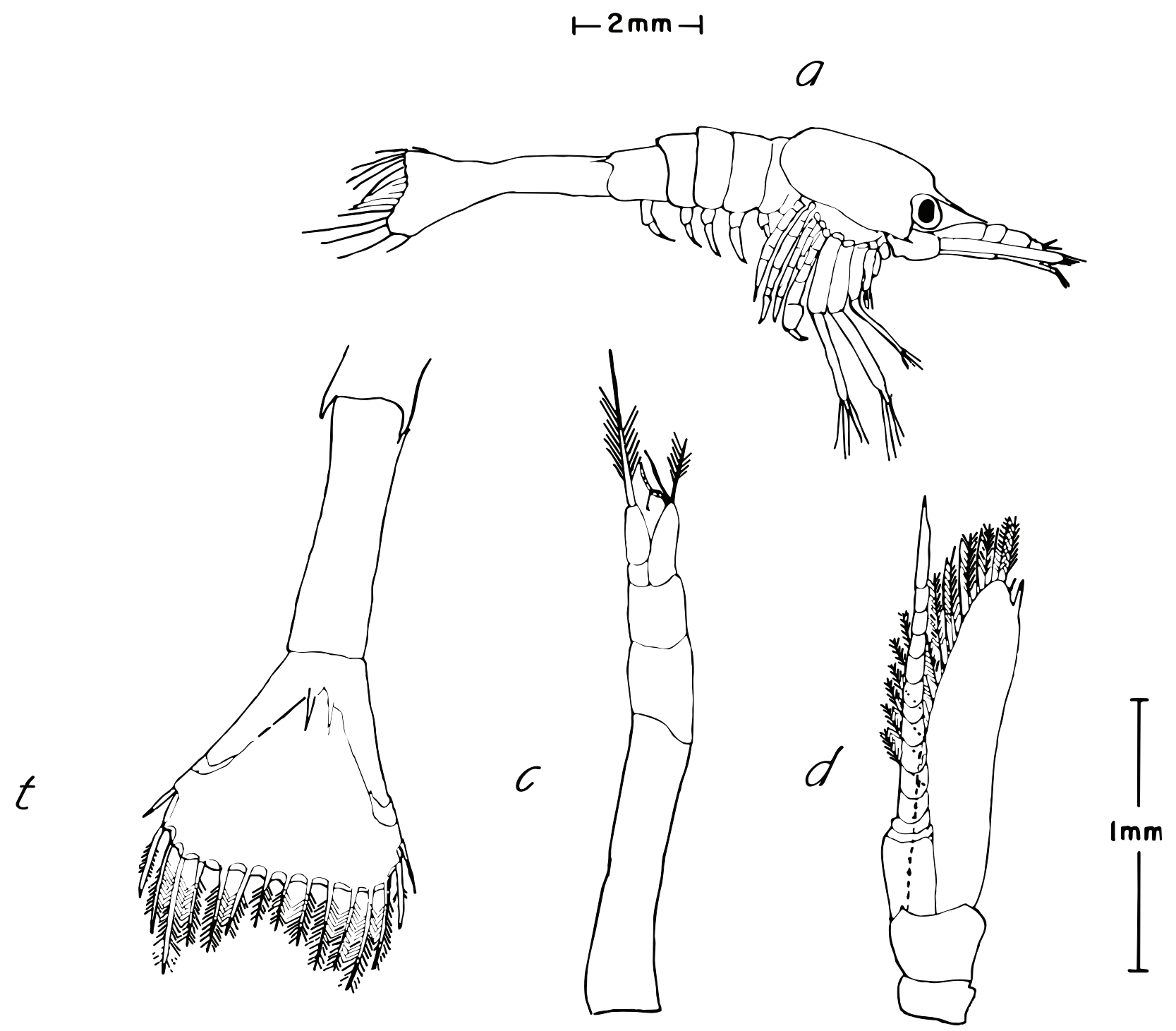

Fig. 54. Argis dentata, Stage I Zoea: (a) antennule; (c) antenna; (t) telson. Scales as indicated. (From Squires, 1965).

Carapace (a): without tubercles or supraorbital spine. Rostrum reaches about one-half length of antennular peduncle. Prominent pterygostomial spine followed by three equidistant anteroventral spines.

Abdomen: abdominal somite 5 only with dorsolateral spine.

Antennule (c): peduncle with 3 articles, the first larger than other two combined; outer flagellum with 3 aesthetes and a plumose seta, inner with long plumose seta.

Antenna (d): scale shorter than flagellum and with fringe of about 15 plumose setae, distolateral spine about even with blade.

Mandibles (e): incisor of right with 2 and of left with 3 teeth, also right with 2 and left with 3 denticles between incisor and molar. 


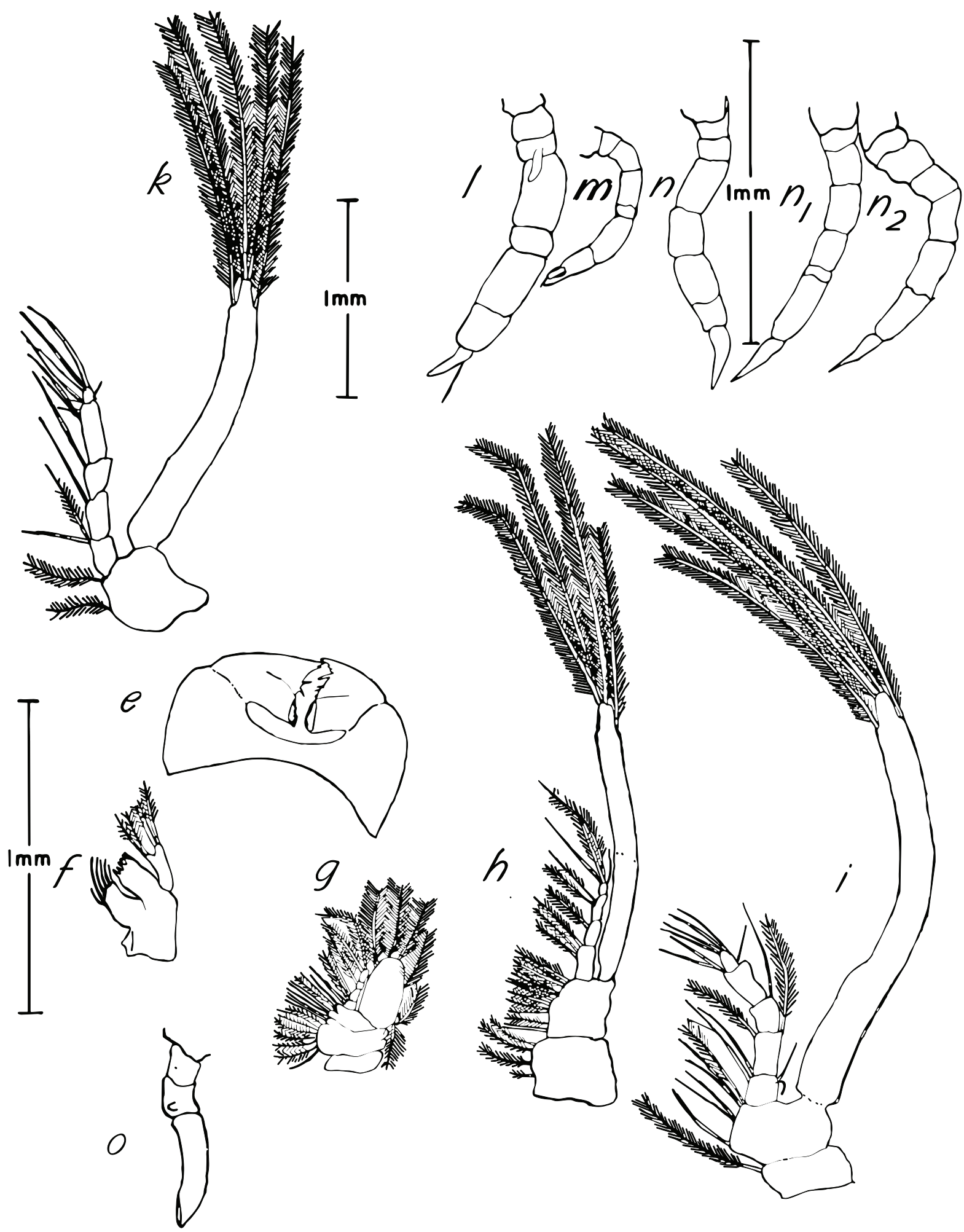

Fig. 55. Argis dentata, Stage I Zoea: (e) mandibles; (f) maxillule; (g) maxilla; (h) first maxilliped; (i) second maxilliped; (k) third maxilliped; (I-n2) pereopods I-V; (o) pleopod. Scales as indicated. (From Squires, 1965). 
Maxillule (f): endopod bifid with 3-4 apical and 2 lateral setae; proximal endite with 4 long curved plumose setae, and distal 2 rows of about $6-8$ short stout setae.

Maxilla (g): anterior lobe of scaphognathite exceeds endopod and has a fan of about 4 plumose setae, posterior lobe scarcely evident but with 2 divergent setae. Proximal and distal endites bilobed with 2 and 8 and 3 and 4 setae, respectively.

First maxilliped (h): exopod more than twice as long as endopod and with 4 apical setae. Endopod with 4 divisions; distal endite with 14 and proximal with 4 setae.

Second maxilliped (i): endopod short with 5 divisions. Exopod the longer by much with 4 apical long plumose setae.

Third maxilliped (k): endopod only about half as long as exopod, the latter with about 5 apical setae.

Pereopods $\left(I-n_{2}\right)$ : rudimentary exopod on basis of first, also dactyl showing early form of subchela. The second shorter than others and chelate. The third to fifth are similar.

Pleopods (o): uniramous but small bud may represent endopod.

Telson (t): with 8 pairs of terminal setae one pair of which is lateral.

Dates of occurrence in plankton hauls: 24June-14 July (Table 3).

Stage II Zoea. Total lengths 9.5-10.4 mm (Fig. 56, 57).

These descriptions are from Squires (1965, fig. 3 and 4).

Differences from Stage I Zoea include expansion or stylocerite formation on first article of antennule as well as a ventral spine. Antennal scale with increase in setal fan to 25 and increase in number of annulations on flagellum. Maxillipeds are more setose.

Carapace (a): with pterygostomial spine and 2 anteroventral denticles. Rostrum sub-equal to first antennular article, and styliform.

Abdomen: not appreciably different from Stage I Zoea.

Antennule (c): first article with proximal expansion and ventral spine; outer flagellum with 2 or more annulations with 3 aesthetes and a few setae, inner with 1 annulation and division into 2 at tip.

Antenna (d): flagellum exceeds scale by about one-fifth its length and has 2 points at tip; scale with about 26 setae.

Mandibles (e): right with incisor of 2 teeth and 3 or 4 denticles between it and molar; left incisor with 3 or 4 teeth and 1 long, 1 short and 3 long denticles.

Maxillule (f): endopod bifid with 3 apical and 2 or 3 lateral setae; distal endite with 7-9 pairs of short spines; proximal with 4 long curved setae and 1 short seta at each side.

Maxilla $(\mathrm{g})$ : endopod with 4 divisions, shorter than anterior lobe of scaphognathite, the latter with 5-8 plumose setae, posterior lobe short with two divergent setae. Endites bilobed, distal with 3-4 and 3-5 plumose setae, and proximal with 8-10 and 2-3 plumose setae. 


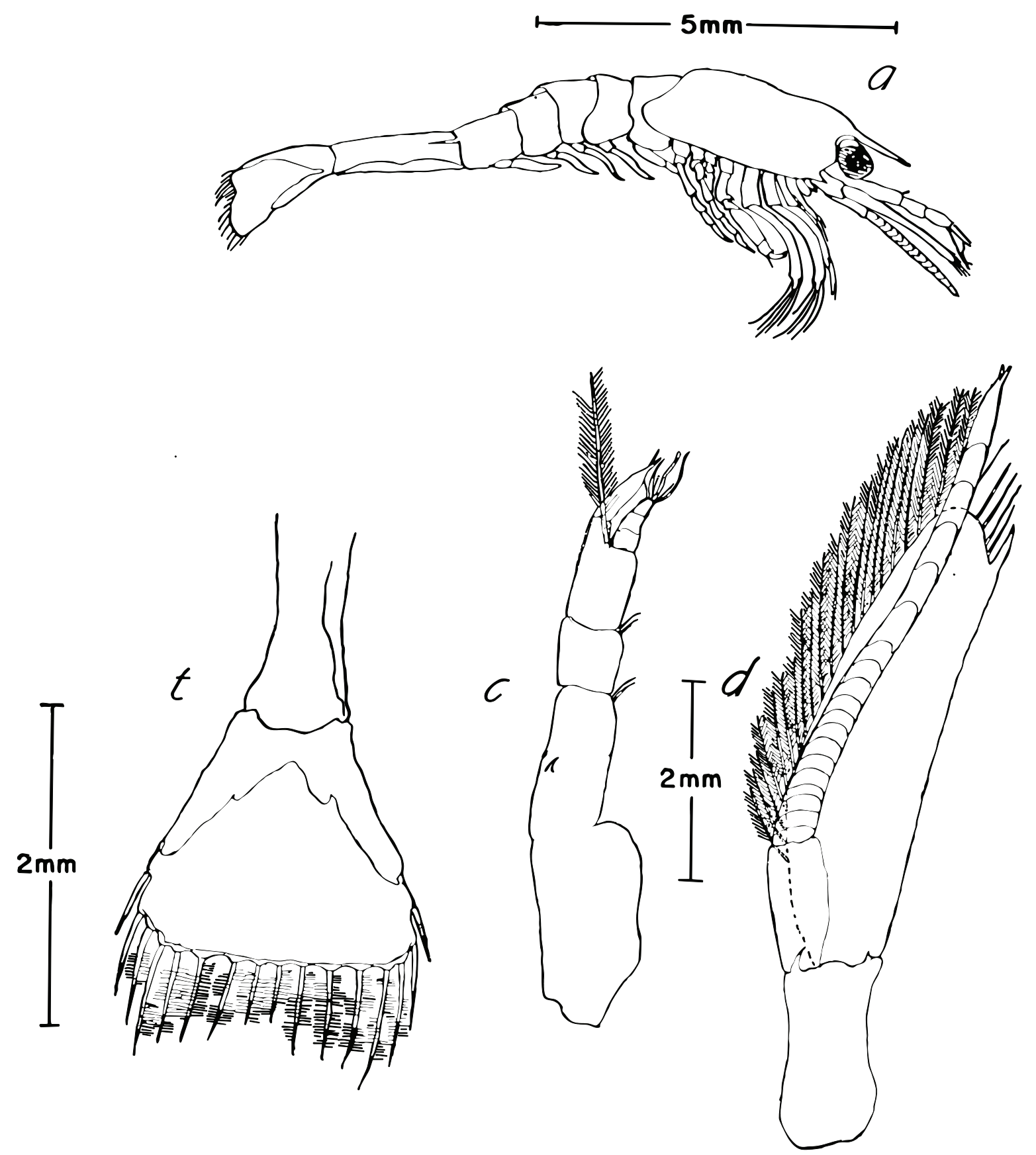

Fig. 56. Argis dentata, Stage II Zoea: (a) whole zoea; (c) antennule; (d) antenna; (t) telson. Scales as indicated. (From Squires, 1965).

First maxilliped (h): endopod short with 4 divisions, exopod much longer with 5 apical long plumose setae; proximal endite with 3 plumose setae and distal with 2 irregular rows of about 20 setae.

Second maxilliped (i): endopod short with 5 divisions, exopod much longer with 6 apical long plumose setae. 


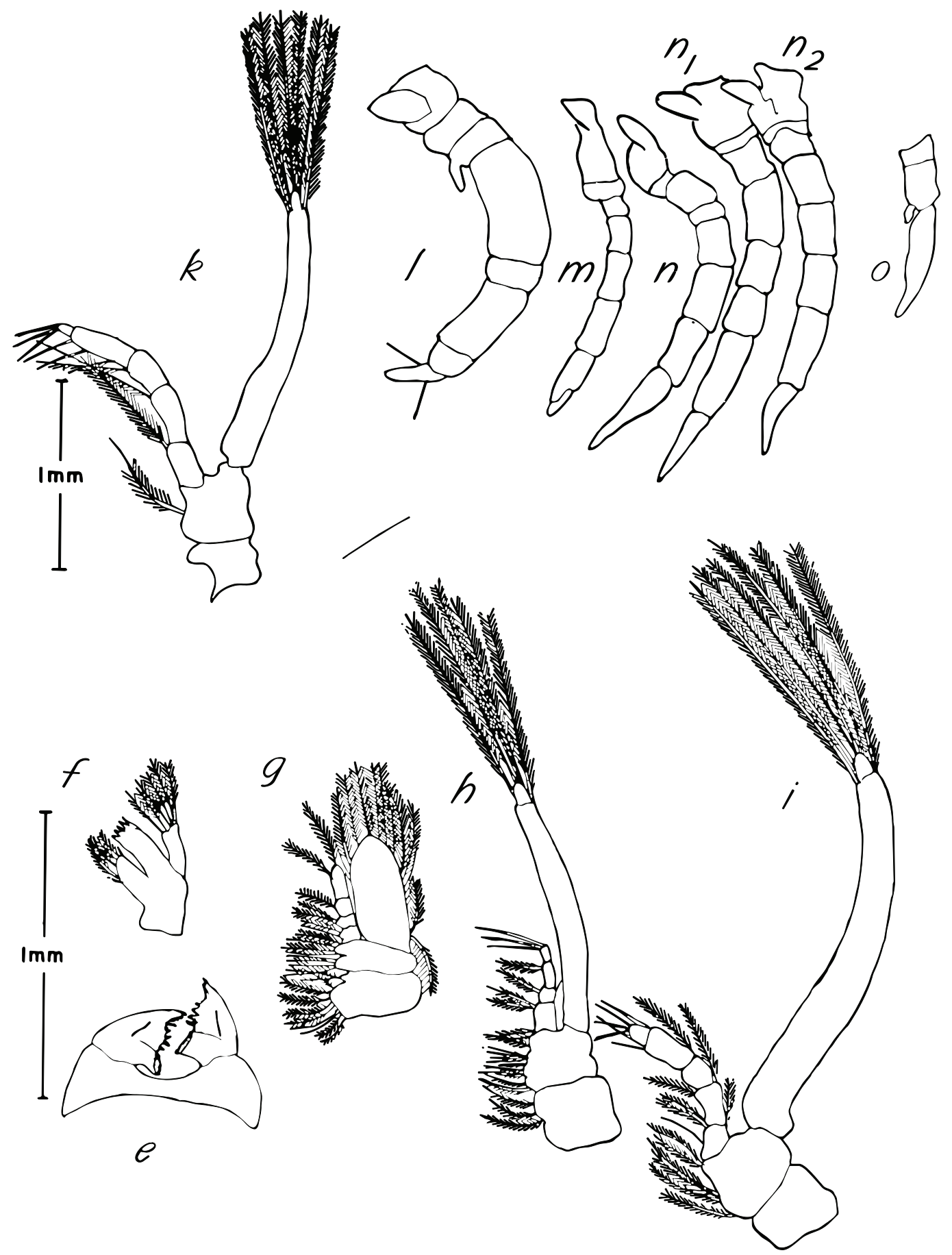

Fig. 57. Argis dentata, Stage II Zoea: (e) mandibles; (f) maxillule; (g) maxilla; (h) first maxilliped; (i) second maxilliped; (k) third maxilliped; (I-n2) pereopods I-V; (o) second pleopod. Scales as indicated. (From Squires, 1965).

Third maxilliped $(k)$ : endopod about two-thirds length of exopod and with 5 divisions, exopod with 6 apical setae.

Pereopods $\left(\mathrm{I}-\mathrm{n}_{2}\right)$ : first pereopod with dactyl well-formed, possibly opposable; the second chelate and shorter than others; the third to the fifth subequal. 
Pleopods (o): biramous but endopod very small.

Telson (t): not appreciably different from Stage I Zoea.

Dates of occurrence in plankton hauls: 10 July-7 August (Table 3).

Megalopa. Total lengths 10.3-12.0 mm (Fig. 58, 59).

These descriptions are from Squires (1965, fig. 5 and 6).

Carapace (a): with ocular, branchiostegal and pterygostomian spines, also a median dorsal carina with 2 spines, border fringed with short plumose setae.

Abdomen: also with setal fringe on pleura.

Antennule (c): first article longer than the other two and with ventral spine at about half length, stylocerite large with distal point; third article shortest; the two flagella short, the outer with 3 divisions and bearing 3-4 aesthetes apically, and the inner with 4 divisions and several setae.

Antenna (d): scale with fan of 30-35 long plumose setae and distolateral spine about reaching tip of blade; flagellum with peduncle of 3 divisions and about 12 annulations.

Mandibles (e): no palp or incisor; molar with 2 pairs of sharply pointed large cusps, the inner pair longer, and 2 or more small accessory cusps per pair.

Maxillule (f): endopod shallowly bifid with one lateral seta; proximal endite with 4 setae one of which is spinous, distal with 2 irregular rows of slightly curved spines.

Maxilla (g): there is some reduction of endites, one lobe only with setae. Endopod slightly shorter than anterior lobe of scaphognathite, the latter with fan of about 35 setae, only the distal and inner ones plumose; posterior lobe narrow but well developed with 5 terminal plumose setae.

First maxilliped (h): endopod shorter than first division of exopod, second division curved and at right angles to first and with 4 apical setae. Conspicuous bilobed epipod.

Second maxilliped (i): endopod with 5 segments and in the form of adult with permanent flexure at 3rd segment. Distal segment shorter than penultimate. Exopod longer, in 2 segments, the distal curved and at right angles to proximal and with 6 apical setae.

Third maxilliped ( $k$ ): endopod long and leglike. Exopod shorter and in 2 segments, the distal curved.

Pereopods $\left(I-n_{2}\right)$ : the first (I) stout and with well-developed subchela. The second $(m)$ slender and chelate. The third $(n)$ slender, longer than others. The fourth $\left(n_{1}\right)$ stout but long and flattened with keel on pointed distal and penultimate segments.

Pleopods (o): exopod much longer than endopod and with long plumose setal fringe. Endopod inconspicuous and with 1 or 2 terminal simple setae.

Telson ( $\mathrm{t}$ ): with a pair of large terminal spines at centre and 3 pairs of smaller spines of different lengths, also 2 pairs of lateral spines.

Dates of occurrence in plankton hauls: 11-20 August (Table 3). 


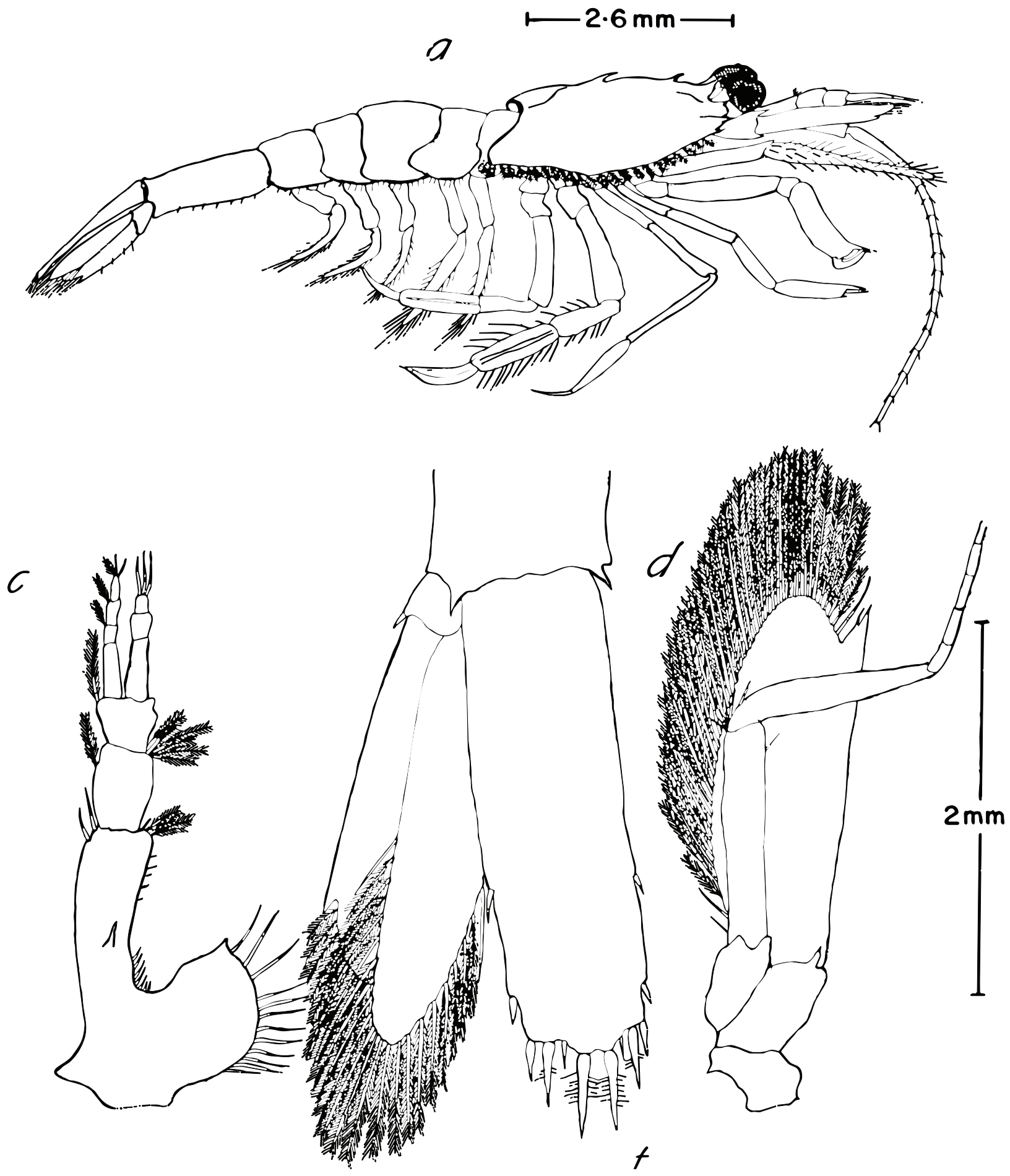

Fig. 58. Argis dentata, Megalopa: (a) whole megalopa; (c) antennule; (d) antenna; (t) telson. Scales as indicated. (From Squires, 1965). 


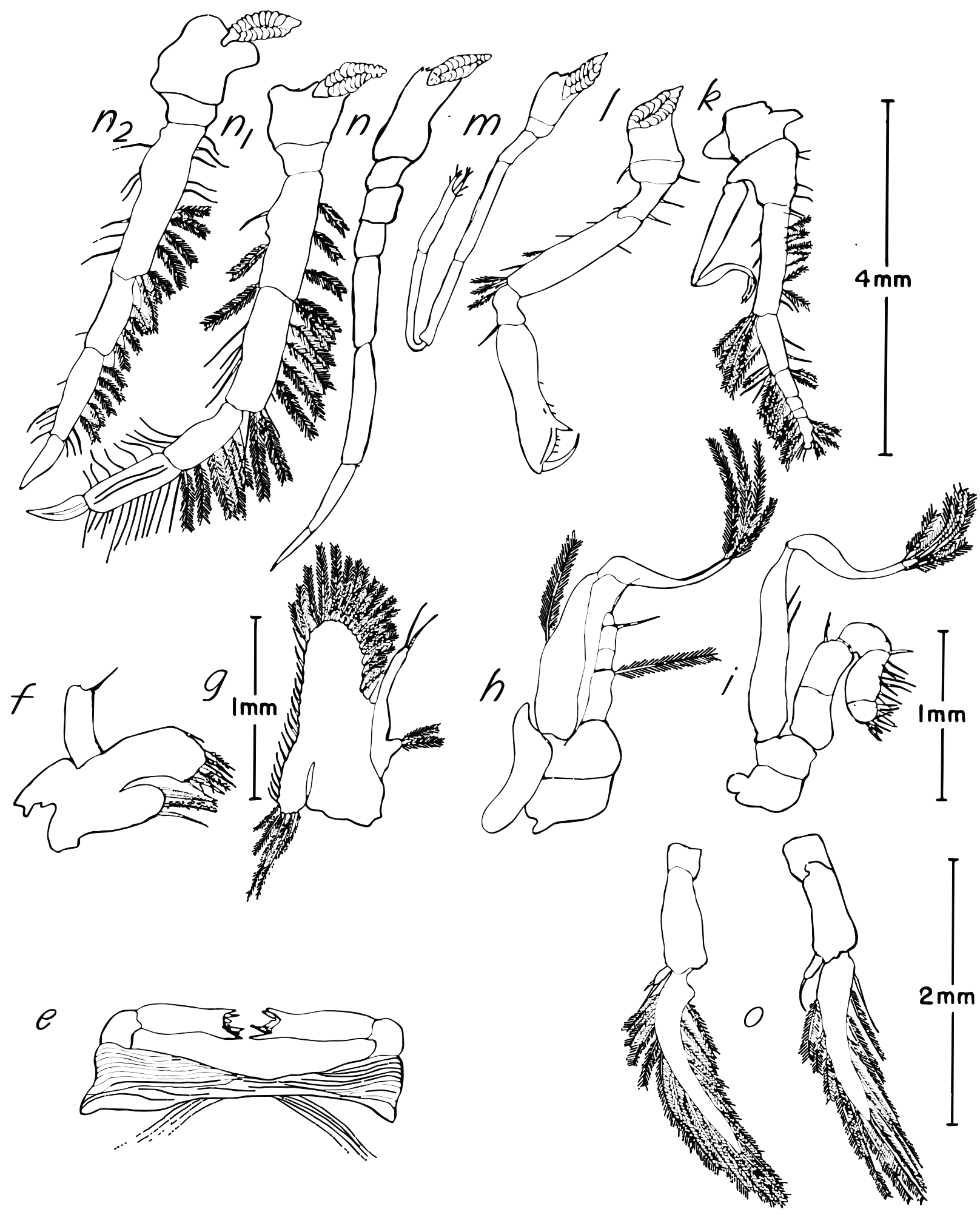

Fig. 59. Argis dentata, Megalopa: (e) mandibles; (f) maxillule; (g) maxilla; (h) first maxilliped; (i) second maxilliped; (k) third maxilliped; (I-n2) pereopods I-V; (o) pleopods. Scales as indicated. (From Squires, 1965). 
Genus Sabinea Ross, 1835

Haynes, 1985: 283.

The larva of this genus is characterized by a very wide telson with shallow notch and many terminal setae. Also ventrolateral spines are on abdominal somites 1-4 and the second to the fifth pereopods are without exopods.

\section{Sabinea septemcarinata (Sabine, 1824)}

Williamson, 1960: 3: fig. 1,2, key;

Sars, 1890: 168; PI. V, fig. 1-23; PI. VI, fig. 1-13.

This species has the largest larvae of any taken in this Bay, and they are readily recognizable from the ventrolateral spines on the abdominal somites 1-4 and a large dorsolateral spine on abdominal somite 5 , and also the large number of terminal setae on the wide telson $(16+16)$. The first pereopods have the beginnings of their subchelate form even in Stage I Zoea and the first and second pereopods are with exopods (Table 10). Total lengths $(\mathrm{mm})$ at different zoeal Stages are as follows: I. 8.4-9.0, II. 9.1-11.2, III. 11.9, IV. 13.0-13.7.

Distribution in Ungava Bay: similar in distribution to Argis dentata, namely, at Tuvalik, Hopes Advance Bay, Inuksulik (1), Leaf Bay, Beacon Island, Adlorilik, and near Port Burwell (Fig. 1; Table 1). No. of specimens taken $=54$ (Table 2).

\section{Description}

Stage I Zoea. Total lengths 8.4-9.0 mm.

The specimens collected were damaged and could not be used for drawings or descriptions.

Stage II Zoea. Total lengths 9.1-11.2 mm (Fig. 60, 61).

Carapace (a): smooth with pterygostomial spine and 5 anteroventral denticles. Rostrum long slender, reaching about two-thirds the length of the antennular peduncle. Eyes large but eyestalks short and globose.

Abdomen: with pleura of somites with ventrolateral spines as follows: 1, 2, 1, 1, and somite 5 with long sharp dorsolateral spines.

Antennule(c): divisions of peduncle not clear; outer flagellum cylindrical with 3 apical aesthetes, inner flagellum awl-shaped slightly longer than outer.

Antenna (d): scale large, outer edge concave, distolateral spine exceeding blade, the latter with fan of about 30 long setae. Flagellum not quite as long as scale.

Mandibles (e): right incisor with one long tooth and a few projections on thin edge between it and molar, left incisor with one long tooth and three small ones plus 4 denticles between it and molar.

Maxillule (f): endites wide, subequal, proximal pointed and with curved setae, distal rounded and with rows of setae. Endopod bifid with 3 setae distally and 2 laterally.

Maxilla (g): proximal endite unequally, distal subequally bilobed, both with long plumose setae. Endopod short and small, only half as long as rounded anterior lobe of scaphognathite, the latter with fringe of about 20 plumose setae; posterior lobe a small corner projection with a backward projecting long plumose seta. 


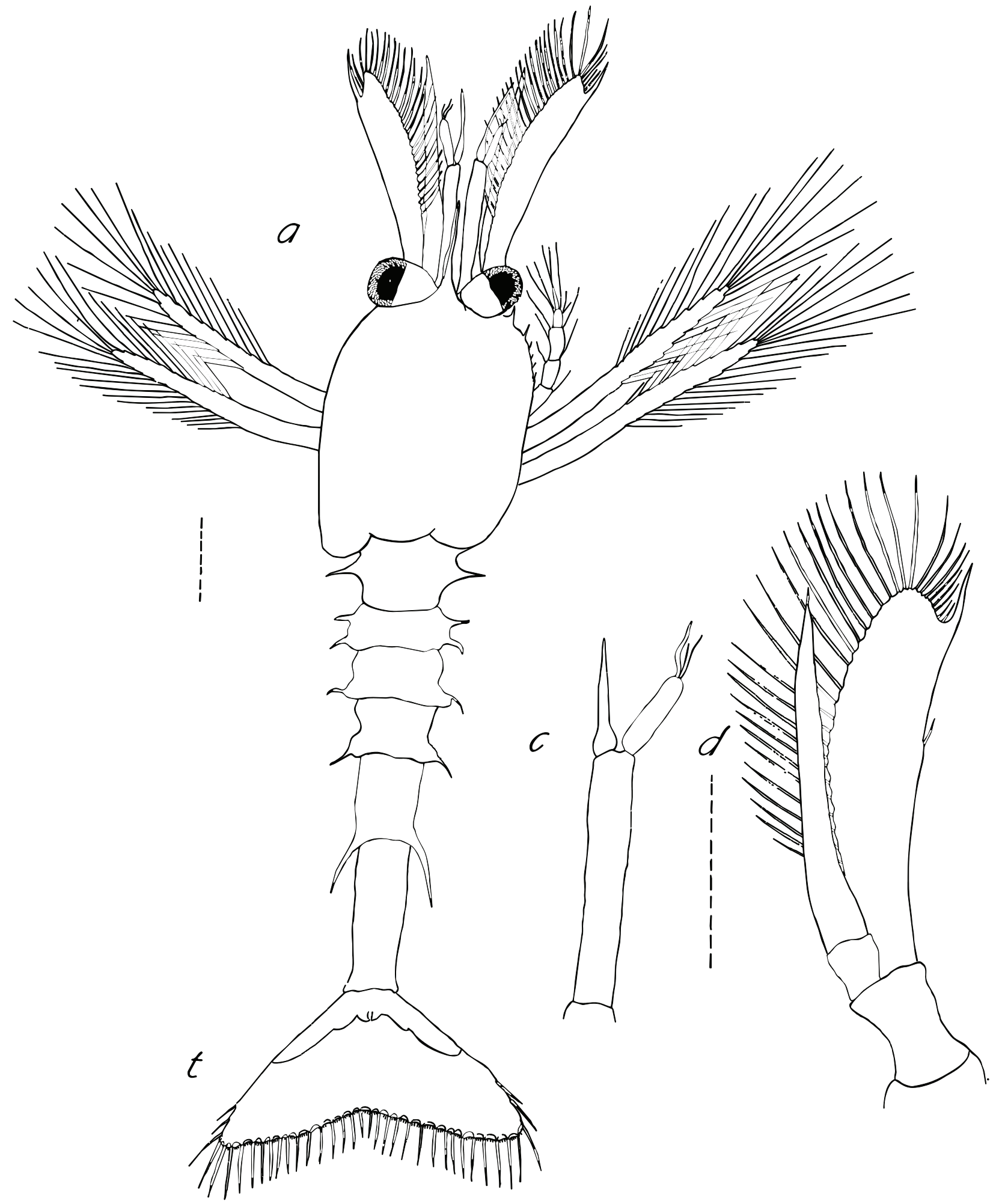

Fig. 60. Sabinea septemcarinata, Stage II Zoea: (a) whole zoea in dorsal aspect; (c) antennule; (d) antenna; (t) telson. Broken line $=1 \mathrm{~mm}$. 


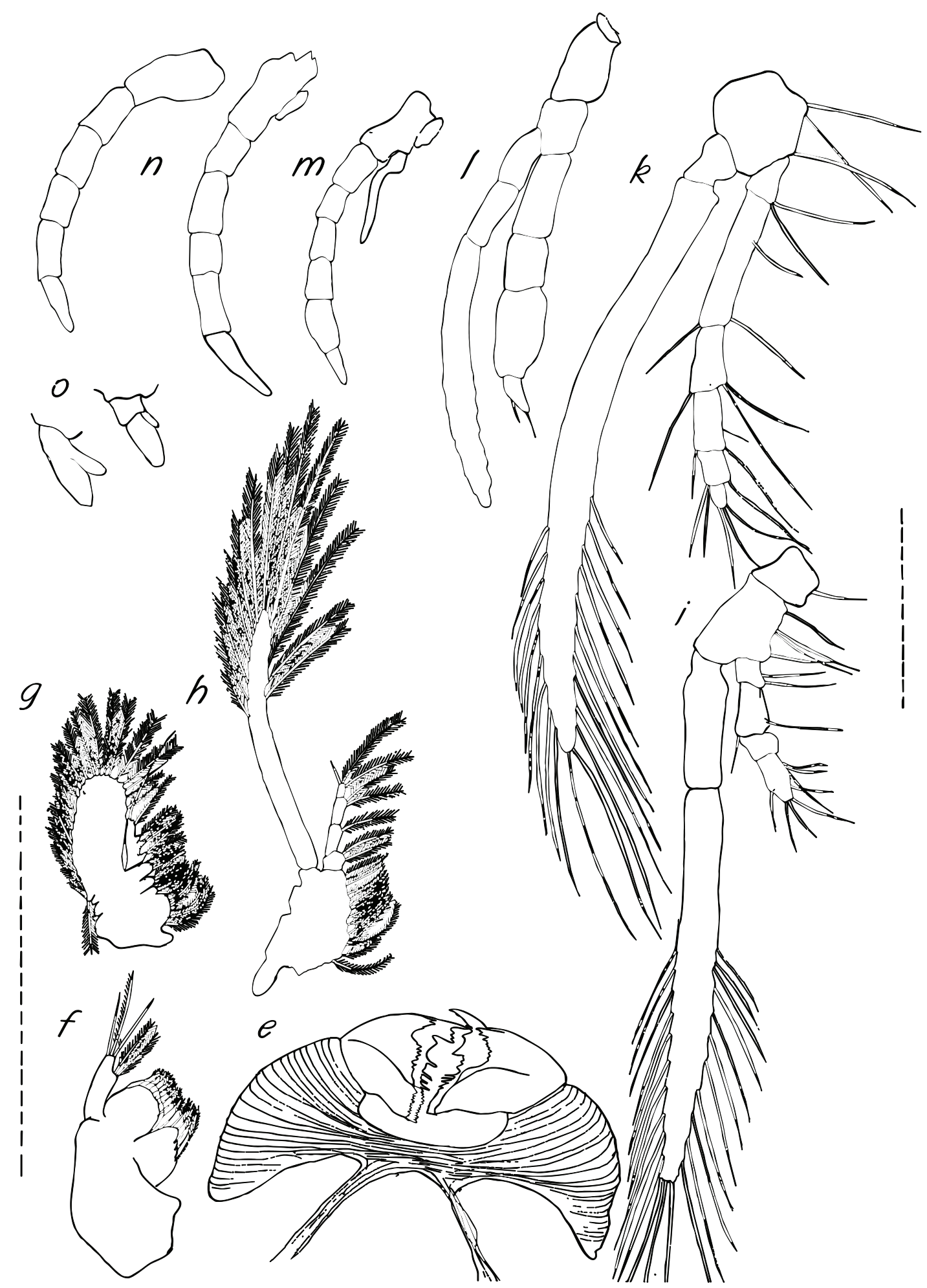

Fig. 61. Sabinea septemcarinata, Stage II Zoea: (e) mandibles; (f) maxillule; (g) maxilla; (h) first maxilliped; (i) second maxilliped; (k) third maxilliped; (I) first pereopod; (m) second pereopod; (n) third pereopod; (o) pleopods. Broken line $=1 \mathrm{~mm}$. 
First maxilliped (h): endites fused, endopod of four divisions, much shorter than long exopod tipped with 15 long plumose setae.

Second maxilliped (i): endopod with 4 divisions very much shorter than long exopod tipped with about 24 long plumose setae.

Third maxilliped $(\mathrm{k})$ : endopod with 6 divisions only, slightly more than half as long as exopod tipped with about 21 long plumose setae.

Pereopods: first (I) with slightly inflated propodus and small dactyl (intimating possible subchela), and slightly longer exopod than endopod. Second pereopod $(\mathrm{m})$ endopod with 7 divisions and a short exopod. The third to fifth are without exopod.

Pleopods (o): biramous.

Telson (t): very wide and shallowly notched with $16+16$ terminal spines plus 3 pairs of lateral spines.

Dates of occurrence in plankton hauls (Table 3):

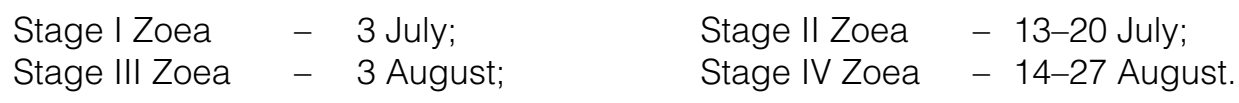

Only Stage II was in satisfactory condition for drawings to be made.

\section{Crangon septemspinosa}

This species does not occur in Ungava Bay nor farther north than the Straits of Belle Isle; however, a description of its larvae is included in Table 10 in comparison with Argis dentata which overlaps with it in distribution. 



\section{Suborder REPTANTIA \\ Infraorder ANOMURA \\ Family PAGURIDAE}





\title{
Suborder REPTANTIA Boas, 1880
}

\author{
Infraorder ANOMURA H. Milne-Edwards, 1832
}

\author{
Family PAGURIDAE Latreille, 1803 \\ Gurney, 1942: 257-262, fig. 106-108, key; \\ McLaughlin and Gore, 1988: 276.
}

Pike and Williamson, 1960: 52.

The larvae of this family (hermit crabs) have the following characteristics (abstracted from Gurney (1942) and Pike and Williamson (1960)): the posteriolateral margins of the carapace project as short spines, the rostrum is smooth, tapering and long, the abdominal somite 5 has a pair of large ventrolateral spines and other somites may have dorsal, ventral and paired dorsolateral spines, the telson has a small hair-like process following the first lateral spine-like process, the endopod of the maxillule has 3 segments, the tip of the antennal scale bears a spine, the third maxilliped endopod is rudimentary in zoeal Stage I.

Genus Pagurus Fabricius, 1775

Macdonald et al, 1957: 219.

The larvae of this genus have large lateral spines on the posterior margin of the abdominal somite 5; 4 pairs of pleopods are present in the last zoea and glaucothoe.

\section{Pagarus acadianus}

No specimens of this species were taken in the survey samples, however, descriptions available from published literature are given in Table 11.

Pagurus pubescens Krøyer, 1838

Macdonald et al., 1957: 226, fig. 4 a-f.

The carapace is large, covering some of the abdominal somites, and the posterior corners extend as short spines; the rostrum is long and tapers to a sharp point. Antennal endopod (flagellum) reaches or exceeds the tip of the rostrum; uropod exopod is tipped with two spines and has five inner long lateral setae. Antennule is bifid in zoeal Stage I. In $P$. acadianus the antennule is acute, the uropod exopod is tipped with only one spine, and the antennal endopod is shorter than the rostrum (Roberts, 1973) (Table 11). Total lengths $(\mathrm{mm})$ at the different zoeal Stages were as follows: I. 3.9-4.5, II. 4.3-5.7, III. 5.3-7.5, IV. 6.8-8.4.

Distribution in Ungava Bay: the larvae of this species were taken in plankton hauls at Tuvalik, Hopes Advance Bay, Koksoak River mouth, Beacon Island, Adlorilik and Port Burwell (Fig. 1; Table 1). No. of specimens taken =1342 counted (Table 2).

\section{Description}

Stage I Zoea. Total lengths 3.9-4.5 mm (Fig. 62). 


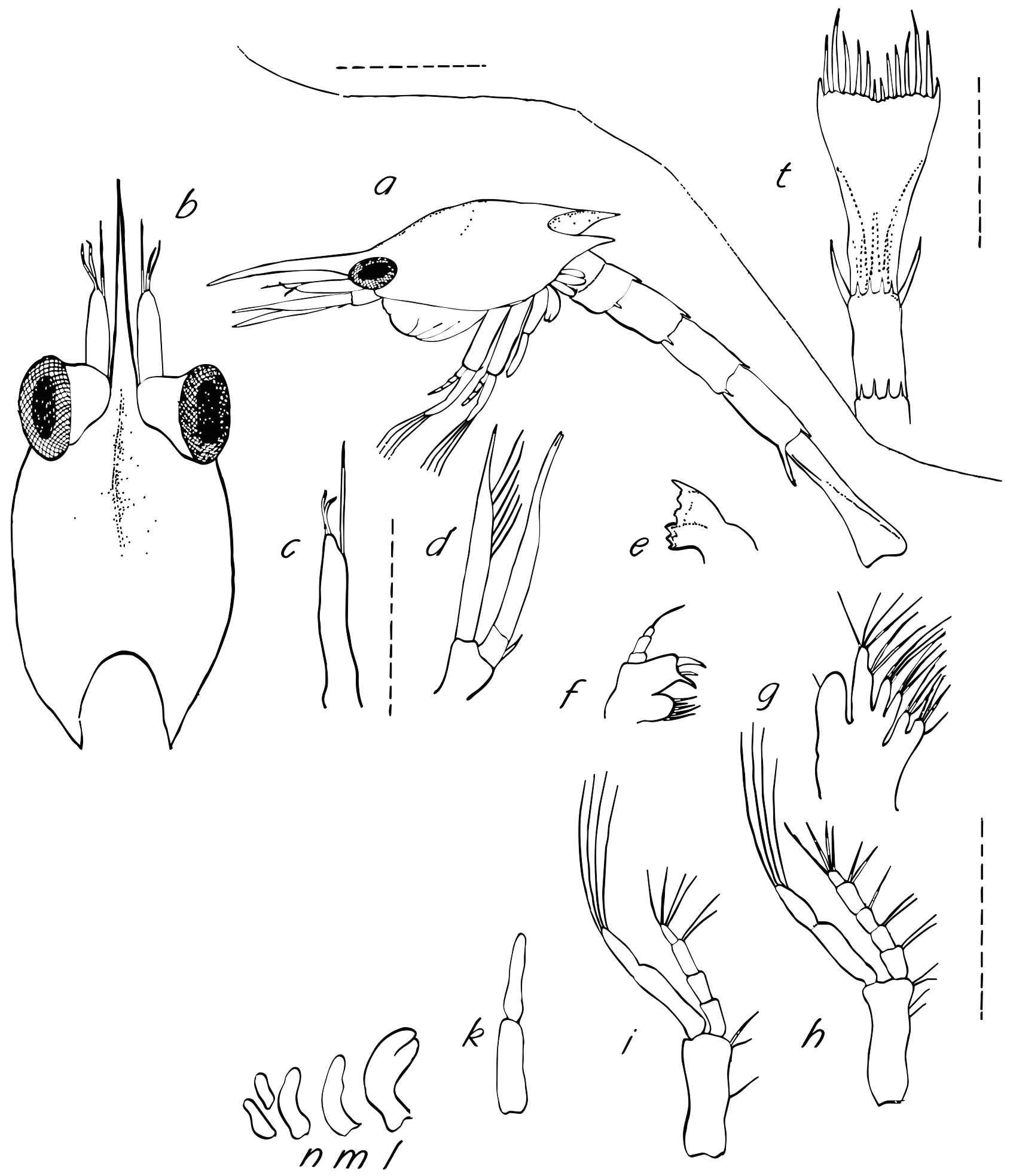

Fig. 62. Pagurus pubescens, Stage I Zoea: (a) whole zoea from left side; (b) dorsal carapace; (c) antennule; (d) antenna; (e) mandible; (f) maxillule; (g) maxilla; (h) first maxilliped; (i) second maxilliped; (k) third maxilliped; (I) first pereopod; (m) second pereopod; (n) third pereopod. Broken line $=1 \mathrm{~mm}$. 
Carapace ( $a$ and $b)$ : about as long as rostrum which tapers to a sharp point and is descending; a median carina begins at base of rostrum and extends about halfway towards posterior margin. Eyes are large and fused with carapace.

Abdomen: has two pairs of dorsal and one ventrolateral spine at posterior edge of each somite, the ventrolateral spine of the fifth is conspicuously long; the sixth somite is fused with the seventh or telson.

Antennule (c): unsegmented with 2 apical aesthetes and a long plumose subapical seta.

Antenna (d): scale with long tapering terminal spine and 6 inner lateral setae. Endopod or flagellum about as long as scale and apically bifid for a short distance, at its base is a long curved ventral spine.

Mandible (e): corner tooth of incisor long, followed by small teeth and 2 rounded projections on its edge before joining the molar, the latter with 2 ridges giving appearance of 2 molars.

Maxillule (f): proximal endite with 5 spinous setae, the distal with 2 strong fang-like spines and a small spine between them. The endopod is 3-segmented and has 1 terminal seta.

Maxilla $(\mathrm{g})$ : endopod is longer than anterior lobe of scaphognathite, the latter with one outer seta. Endites subequally bilobed and with long terminal setae.

First maxilliped (h): endopod with 5 divisions and 2, 2, 1, 2 and 4 setae from base to tip. Exopod slightly longer, with 4 long apical setae.

Second maxilliped (i): endopod with 4 divisions; exopod slightly longer with 4 long apical setae.

Third maxilliped (k): no sign of endopod. Exopod short and without setae.

Pereopods: unsegmented buds showing first formation of chela in the first pereopod (I). The fifth is very small, behind the third ( $n$ ) and fourth.

Pleopods: none.

Telson ( $\mathrm{t}$ ): has the first lateral spinous process unsutured but all the others are sutured, and among which the fourth (apparent third) process is longest. The anomuran hair was not present in the preserved specimens examined.

Date of occurrence in plankton hauls: 24 June only (Table 3).

Stage II Zoea. Total lengths 4.3-5.7 mm (Fig. 63, 64).

Carapace ( $a$ and $b)$ : is large in relation to the rest of the body and covers the first 2 abdominal somites; posterior spines are straight and reach as far as somite 4 . There is a faint mid-dorsal carina extending from the base of the rostrum and almost reaching the posterior edge of the carapace. Eyes are large, the stalks free from the carapace at this Stage.

Abdomen: is narrow and has 2 dorsal, 2 dorsolateral and 2 ventral spines on the posterior edge of somites 2 to 5 , of which the ventrolateral spines on the 5th are the largest by much.

Antennule (c): unsegmented but outer flagellum appears as a rounded cap bearing 2 aesthetes and a seta, the inner is a long plumose seta. 


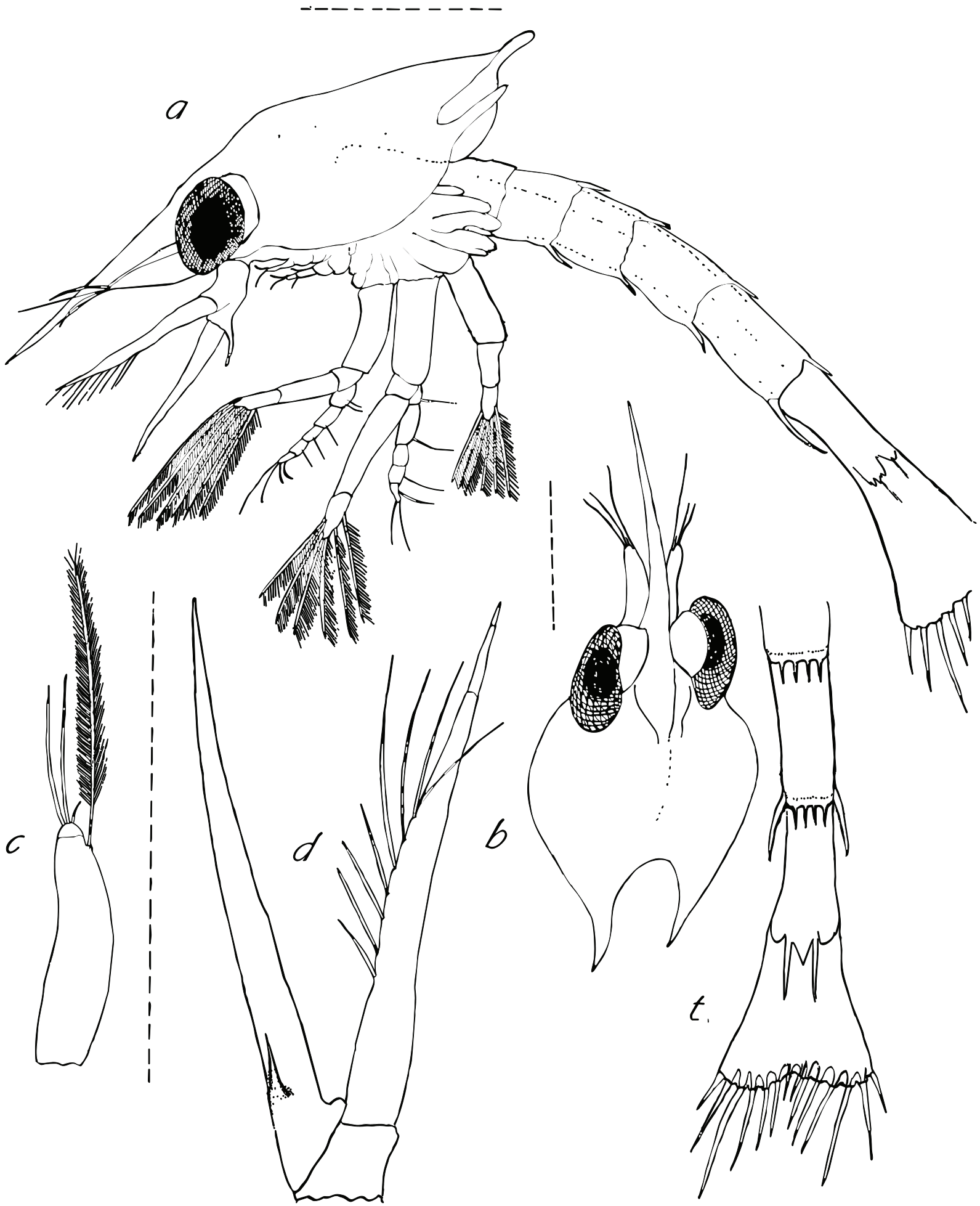

Fig. 63. Pagurus pubescens, Stage II Zoea: (a) whole zoea from left side; (b) dorsal carapace; (c) antennule; (d) antenna; $(\mathbf{t})$ telson. Broken line $=1 \mathrm{~mm}$. 


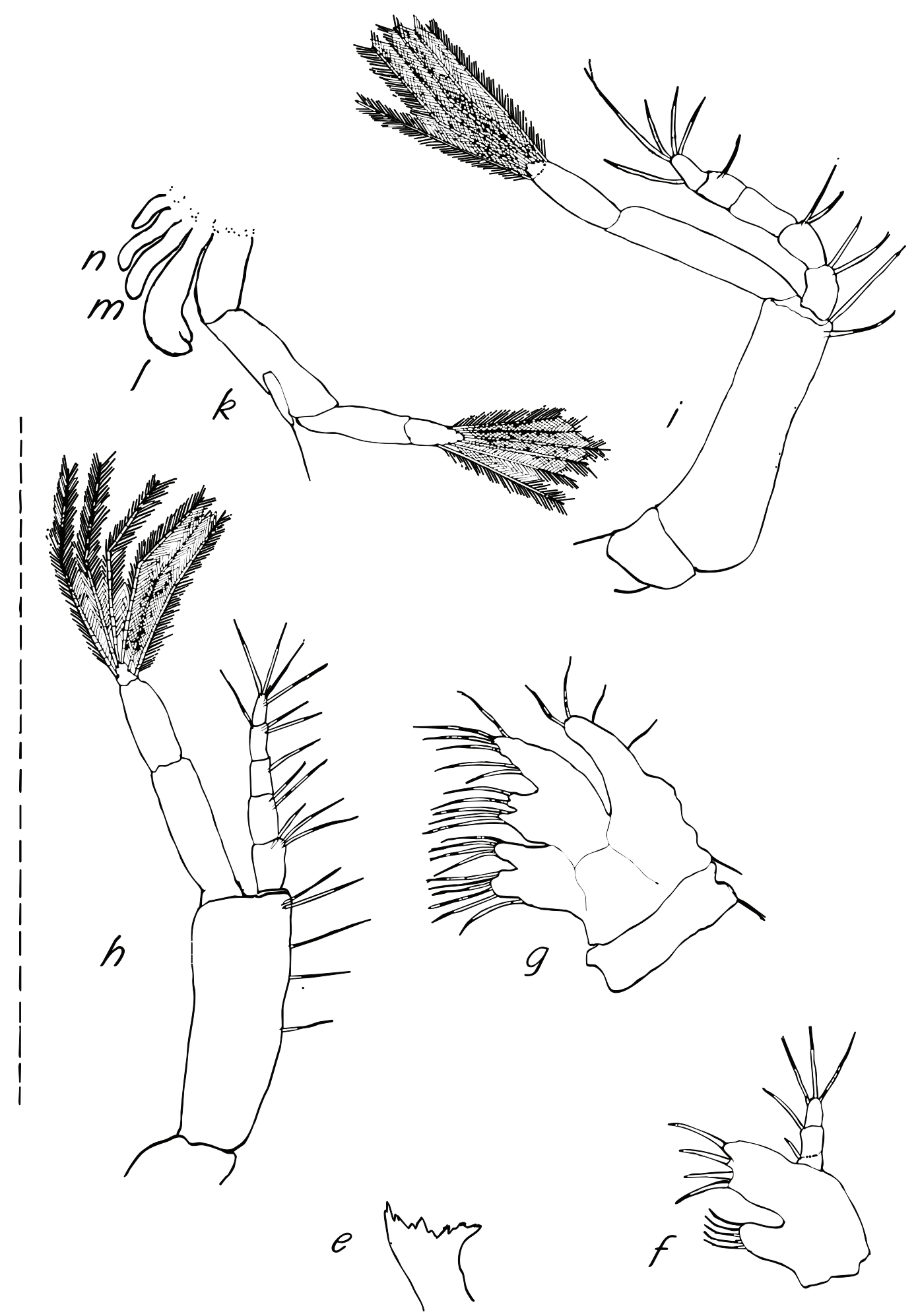

Fig. 64. Pagurus pubescens, Stage II Zoea: (e) mandible; (f) maxillule; (g) maxilla; (h) first maxilliped; (i) second maxilliped; (k) third maxilliped; (I) first pereopod; (m) second pereopod; (n) third pereopod. Broken line $=1 \mathrm{~mm}$. 
Antenna $(d)$ : scale is narrow and tapering to terminal spine and bears about 8 long setae; the flagellum is slightly longer, its base has a strong ventral spine.

Mandible (e): molar is strongly toothed and without palp.

Maxillule (f): proximal endite has 5 strong curved setae and is less than half as large as distal, the latter stout and with 4 slightly curved setae. The endopod appears 3-segmented and has 3 apical setae plus one each at the end of the other segments.

Maxilla (g): proximal endite subequally bilobed somewhat larger than the subequal lobes of the distal. Endopod stout and longer than anterior lobe of scaphognathite, the latter with only about 4 setae, it has no posterior lobe but a proximal spine.

First maxilliped (h): endopod 5-segmented, exopod 2-segmented slightly longer than endopod, with 6 apical long plumose setae.

Second maxilliped (i): endopod with 5 segments, exopod slightly longer and with 2 segments and 6 long plumose setae distally.

Third maxilliped $(\mathrm{k})$ : endopod is small and inserted at about distal third of the basis. The exopod smaller than in the other two and with 2 segments and 6 apical setae.

Pereopods: bud-like but the first (I) with preliminary formation of a chela. The fifth is small, hidden behind the fourth.

Pleopods: none.

Telson (t): has $6+6$ terminal setae plus a lateral spine at each corner (no hair as the second telson process could be found in many specimens examined but may have been lost in preservative), the 3rd setae is larger than the others, and there is a small central pair and notch.

Dates of occurrence in plankton hauls: 24 June-20 July (Table 3).

Stage III Zoea. Total lengths 5.3-7.5 mm (Fig. 65, 66).

Carapace (a): large, with its posterior spinous processes appearing about half the total length; median carina extending from base of rostrum to posterior edge. The rostrum is long and tapering, reaching just beyond the antennae and almost as long as the carapace.

Abdomen: each of 4 posterior abdominal somites with 2 dorsolateral, 2 dorsal and 2 ventrolateral spines, the latter exceptionally large and long on somite 5 (as in Stage II).

Antennule (c): peduncle still unsegmented; outer flagellum with a long distal aesthete and a shorter lateral one plus a couple of setae, inner conical and shorter than the outer and with 2 long plumose apical setae.

Antenna (d): scale narrow with a long sharp apical spine and a fan of about 8 moderate setae; flagellum unsegmented, slightly longer than scale.

Mandibles (e): incisor with a long corner tooth and a couple of smaller teeth between it and molar.

Maxillule (f): proximal endite small rounded and with a fringe of a few spinous setae, distal endite twice as large and with 4 long spines. Endopod with 3 segments and 3 apical and 1 lateral seta. 


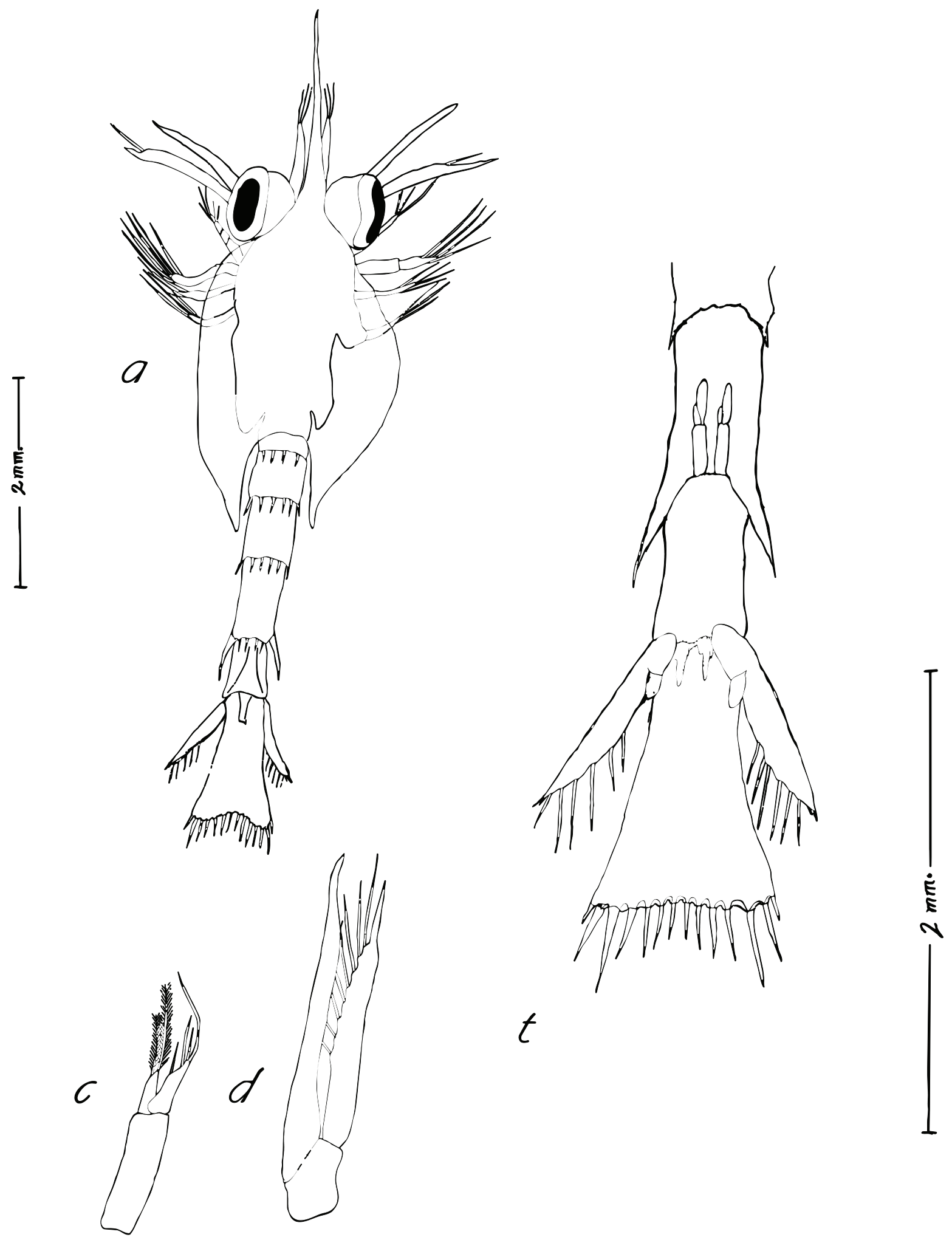

Fig. 65. Pagurus pubescens, Stage III Zoea: (a) whole zoea in dorsal aspect; (c) antennule; (d) antenna; (t) telson. Scales as indicated. 

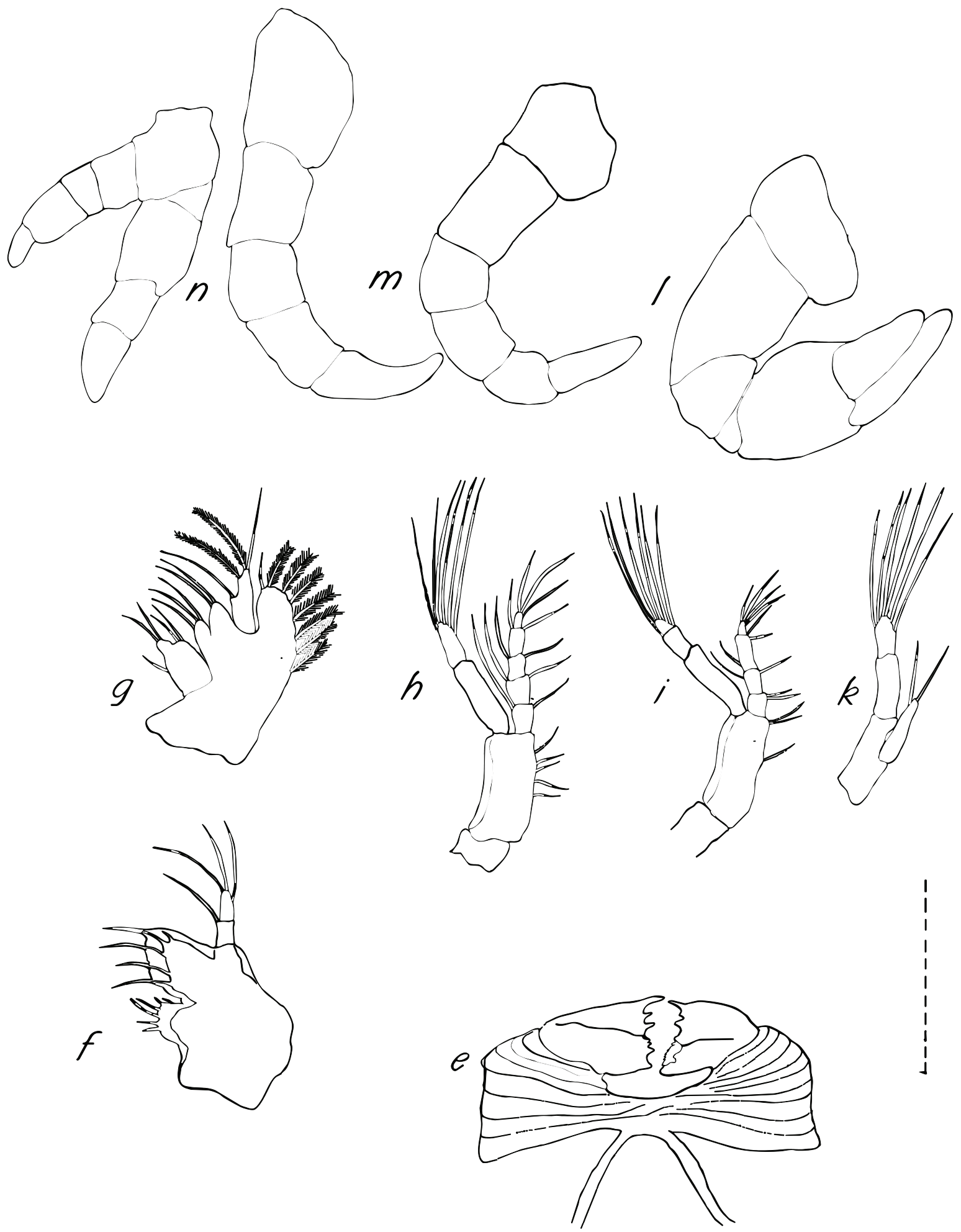

Fig. 66. Pagurus pubescens, Stage III Zoea: (e) mandibles; (f) maxillule; (g) maxilla; (h) first maxilliped; (i) second maxilliped; (k) third maxilliped; (I) first pereopod; $(\mathbf{m})$ second pereopod; $(\mathbf{n})$ third pereopod. Broken line $=1$ $\mathrm{mm}$. 
Maxilla (g): proximal endite obscurely bilobate, distal endite unequally bilobed. Endopod exceeding anterior lobe of scaphognathite, the latter with a fringe of about 8 plumose setae, no posterior lobe.

First maxilliped (h): five-segmented endopod not as long as exopod, the latter with 5 long apical setae.

Second maxilliped (i): four-segmented endopod about as long as exopod, the latter with 6 long apical setae.

Third maxilliped $(k)$ : smaller than others, endopod inserted at about half the basis and short and unsegmented, with two apical setae, much shorter than exopod, the latter with 6 long apical setae.

Pereopods: the first (I) stout and chelate, second $(m)$ and third $(n)$ more slender and about equal, fourth and fifth smaller and close together, all partly segmented.

Pleopods: none.

Telson $(\mathrm{t})$ : with $7+7$ processes, lateral pair unsutured, the third pair largest, anomuran hair possibly lost in preservative; outer branch of uropod much more developed than very small inner branch, and with about 6 long inner setae.

Dates of occurrence in plankton hauls: 13 July-4 August (Table 3).

Stage IV Zoea: Total lengths 6.8-8.4 mm (Fig. 67).

Carapace ( $a$ and $b$ ): has a pronounced mid-dorsal carina from base of rostrum, forming a crest over the gastric area and reaching the posterior edge, an antennal spine is present.

Abdomen: is as in other Stages but 4 pairs of biramous pleopods are now present.

Antennule (c): with slight outer protrusion proximally and faint segmentation; outer flagellum with 3 apical spines and 2 lateral bunches of aesthetes or setae; the shorter inner flagellum has 2 setae apically and 1 long adjacent seta.

Antenna (d): scale with strong apical spine and about 9 lateral long setae, strong spine at base ventrally; flagellum showing faint segmentation, longer than scale, with very strong sharp spine at base ventrally.

Mandible (e): incisor a long sharp tooth followed by several small teeth on edge with gap at strongly toothed molar (appearing as 2 unequal molars). Palp is present as a small rounded bud proximally inside.

Maxillule (f): proximal or coxal endite small, rounded, with 6 curved setae; distal or basal endite with 6 strong uneven teeth; endopod with 2 setae on apical segment and 1 seta on proximal or third segment.

Maxilla (g): both proximal and distal endites equally bilobed and with few setae. Endopod slightly longer than anterior lobe of scaphognathite, the latter with about 12 very fine setae; posterior lobe narrow and almost as long as anterior lobe, without setae.

First maxilliped (h): has a 5-segmented endopod shorter than the exopod, the latter with 8 long apical setae. 


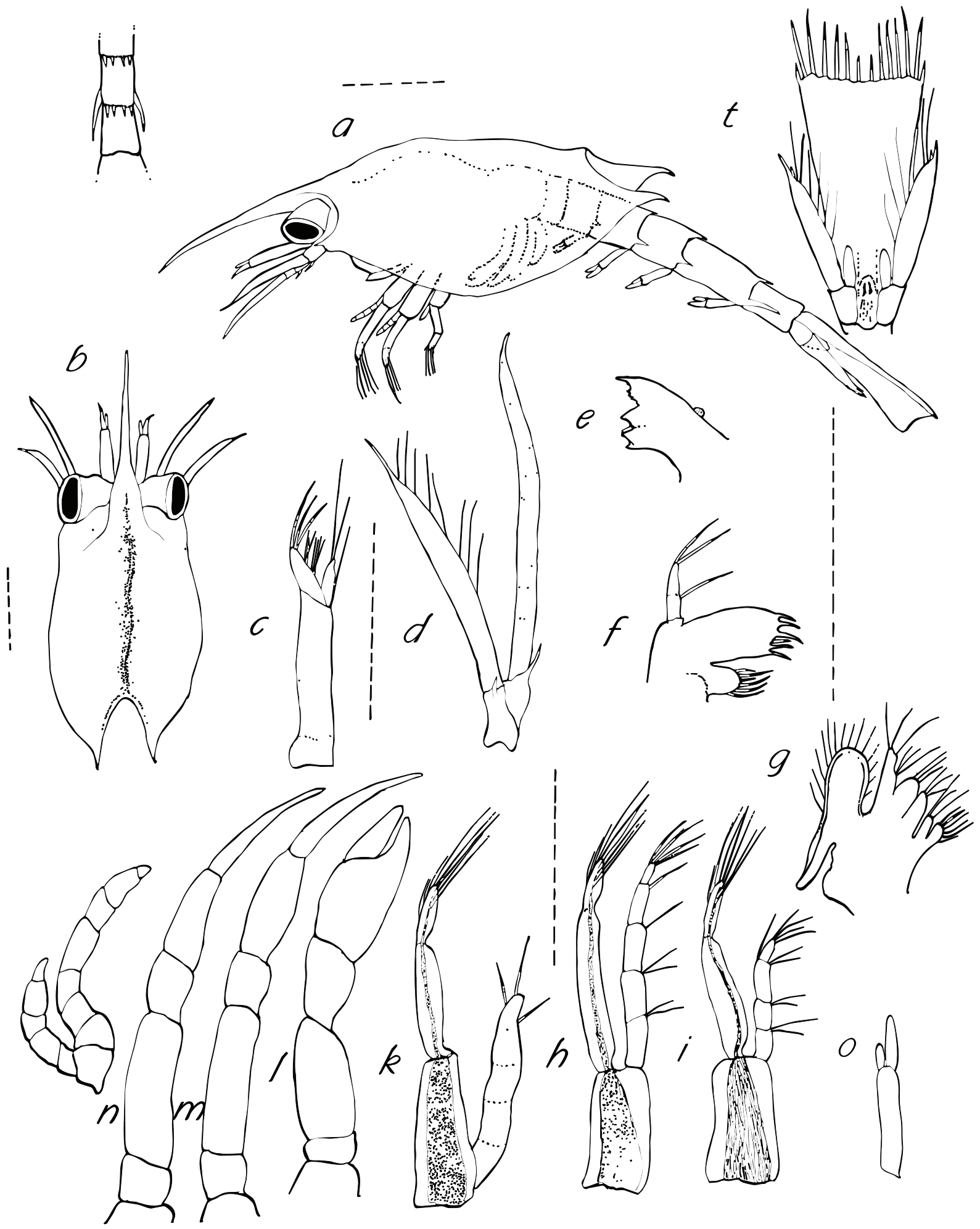

Fig. 67. Pagurus pubescens, Stage IV Zoea: (a) whole zoea from left side; (b) dorsal carapace; (c) antennule; (d) antenna; (e) mandible; (f) maxillule; (g) maxilla; (h) first maxilliped; (i) second maxilliped; (k) third maxilliped; (I) first pereopod; (m) second pereopod; (n) third pereopod; (o) pleopod. Broken line $=1 \mathrm{~mm}$. 
Second maxilliped (i): has a 4-segmented endopod about as long as the exopod, the latter with about 8 long apical setae.

Third maxilliped ( $k$ ): endopod about as long as exopod but inserted proximally on base, faintly 5-segmented. Exopod with 8 long apical setae.

Pereopods: the first (I) very stout, strongly chelate. The second $(m)$ and third $(n)$ similar slightly longer than the first and with very long dactyl. The fourth is small and the fifth smaller, appearing to be attached to each other at coxa. The fifth with 6 indistinct segments.

Pleopods (o): 4 pairs only, similar, biramous.

Telson (t): has $7+7$ terminal processes (no evidence of hair in second position), the outer small spines seemingly fused with the edge and possibly unsutured but others are all sutured. Outer branch of the uropod with strong apical and small accessory spine and inner fringe of about 6 long setae; inner branch small, about one-quarter the length of the outer.

Dates of occurrence in plankton hauls: 14-27 August (Table 3). 
Infraorder BRACHYURA

Family MAJIDAE 



\title{
Infraorder BRACHYURA Latreille, 1803 \\ Family MAJIDAE Samouelle, 1819
}

Lebour, 1928: 541-551. fig. 4 (14, 15),

As in the majority of the Brachyura, the typical crab Zoea has long rostral, dorsal and lateral spines on the carapace, a slender curved abdomen and a bifurcate telson (Gurney, 1942). Antennal exopod about one-half as long as spinous process; lateral spines on abdominal somites 2 and/or 3; telson with 2 or 3 lateral setae in zoeal Stages I and II. Only two zoeal stages.

\author{
Genus Hyas Leach, 1814 \\ Lebour, 1928: 486, key; 544; fig. 2 (1,2), \\ 5 (29,30); Lebour, 1931: 95; \\ Christiansen, 1973.
}

Large spines on carapace covered with spinules on distal two-thirds; antennal exopod less than half spinous process; lateral spines or horns on second and third abdominal somites; telson with three lateral setae in Stage I and four in Stage II; long lateral spines on abdominal somites 2 to 5 in both zoeal stages.

\section{Hyas araneus}

This species does not occur in Ungava Bay, however, descriptions available from published literature are given in Table 12.

\author{
Hyas coarctatus Leach, 1815 \\ Lebour, 1928: 544, PI. II, 9; PI. XIV, 8-10. \\ Christiansen, 1973: 63-89, fig. 1-17.
}

Hyas coarctatus alutaceus, Pohle, 1991: 2717-2737, fig. 1-6.

Spinous process of antenna almost as long as rostral spine, exopod less than a third of its length. Long setae at ventral margin of carapace. Colour brownish. Compared with $H$. araneus the zoeal stages of this spider crab are smaller when taken from the same area, the rostral spines in the Zoea are more spinulose and the spinules are larger, also the colour is less distinct (Christiansen, 1973) (Table 13). Zoea from Ungava Bay described in the present work are larger than those of specimens of both species from Norway described by Christiansen $(H$. araneus does not occur in Ungava Bay). Pohle 1991 believes that these larvae belong to the subspecies $H$. c. alutaceus. Total lengths $(\mathrm{mm})$ at the zoeal Stages are as follows: I. 4.0-4.7, II. 5.0-6.0.

Distribution in Ungava Bay. The larvae of this species were the most ubiquitous of decapods in the bay and present at almost all plankton stations from Koaktuk, Diana Bay in the west to Port Burwell and the Button Islands in the east (Fig. 1; Table 1). No. of specimens taken $=5618$ (Table 2). 


\section{Description}

Stage I Zoea. Total lengths 4.0-4.7 mm (Fig. 68, 69).

(Measurements of total length were from tip of rostrum to tip of dorsal spine; Lebour (1928) measured from the front of the head to the tip of the telson fork (p. 507). A "spine to spine" measurement mentioned by Lebour (1928) equals from the tip of the rostrum to the tip of the dorsal spine: in $H$. coarctatus of Britain $=3 \mathrm{~mm}$ ).

Carapace lengths $0.5-0.7 \mathrm{~mm}$ (from eye socket to posterior edge of carapace in mid-line).

Carapace ( $a$ and b): sub-globular, rostral and dorsal spines conspicuous, long and with spinules from the tip to more than half their length; lateral spines are less than half as long as dorsal but are covered with spinules. Ventro-laterally are 3 setae increasing in size posteriorly. Eyes are large, globular and attached along one side.

Abdomen: with dorsolateral horns on somites 2 and 3 and long posterolateral spines on somites 3 to 5; somite 6 is fused with telson at this Stage.

Antennule (c): stout and somewhat conical in shape with 2 long aesthetes and 2 short setae distally.

Antenna $(\mathrm{d})$ : endopod is only a bud, the protopod has a long pointed process which is almost as long as the rostrum and has many spinules on the distal half, the exopod is slender, less than half the protopodal process and has 3 small apical setae. Over most of its length are many small setae.

Mandible (e): molar stout and flattened distally, with 2 prominent lateral incisors.

Maxillule (f): proximal endite small, rounded, with 5 distal setae or spines; distal endite about twice as large, rounded, with 6 setae. Endopod longer than endites, with 2 main segments and distally 6 setae, 2 of which may be lateral.

Maxilla (g): proximal endite smaller than distal, both obscurely bilobed. Endopod stout, rounded, with 5 setae distally, larger than anterior lobe of scaphognathite, the latter somewhat pointed at the apex, with a short posterior lobe and terminal spine and about 12 fringing setae.

First maxilliped (h): endopod with 5 segments, not quite as long as the exopod, the latter with 2 segments and 4 long plumose apical setae.

Second maxilliped (i): endopod with 3 segments, about half as long as the 2-segmented exopod, the latter with 4 long plumose apical setae.

Third maxilliped (k): tiny, budlike with a short exopod.

Pereopods: first (I) with few divisions and incipient chela. The second $(\mathrm{m})$ to the fifth are smaller than the first.

Pleopods: none.

Telson ( $\mathrm{t}$ ): bifurcate, long narrow forks at the base of which are 2 outer spines and 3 inner setae on each fork.

Dates of occurrence in plankton hauls: 24 June-20 August (Table 3). 


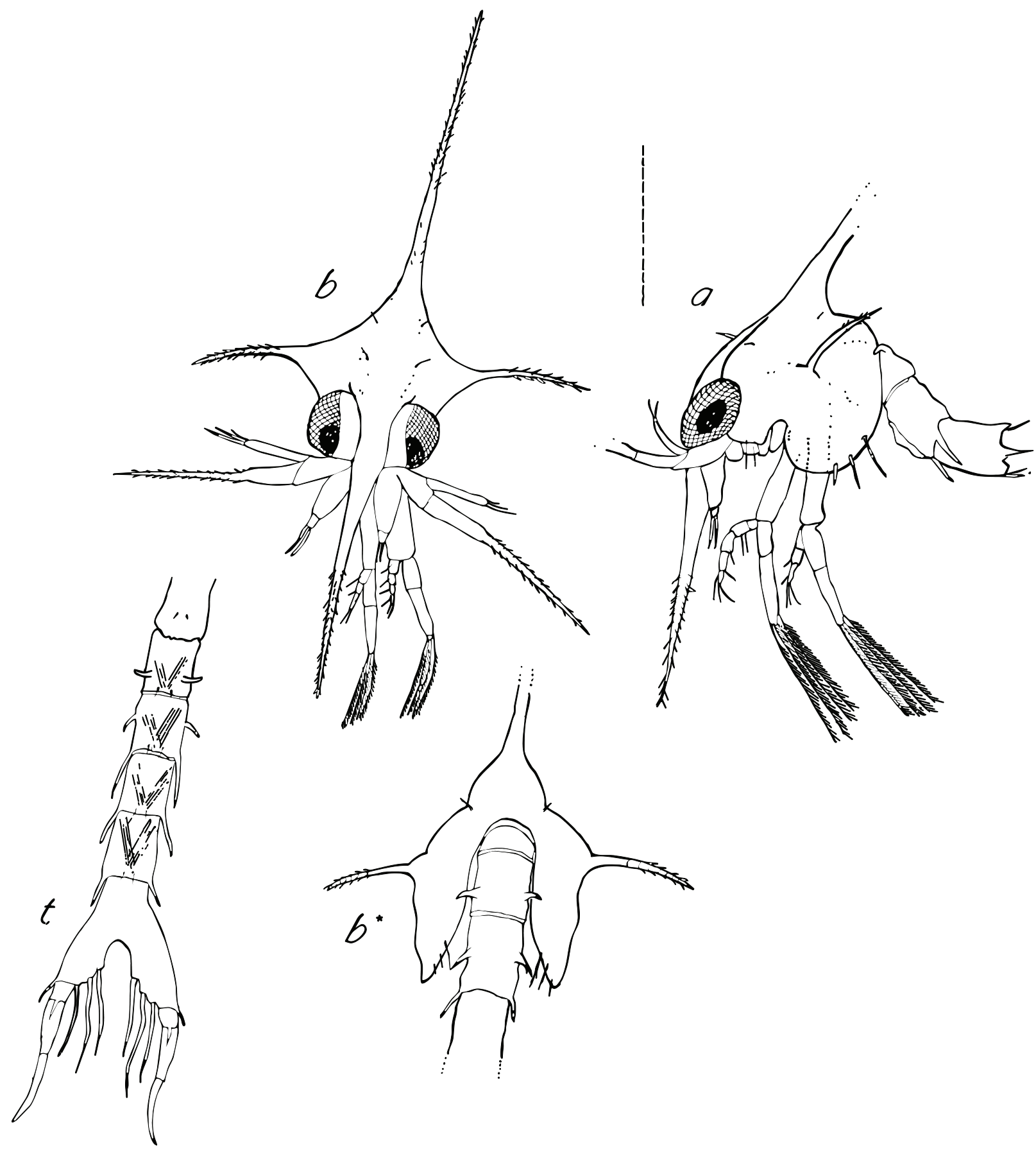

Fig. 68. Hyas coarctatus, Stage I Zoea: (a) carapace from left side; (b) carapace from in front; ( $\mathbf{b}^{\star}$ ) carapace from behind; (t) telson. Broken line $=1 \mathrm{~mm}$.

Stage II Zoea. Total lengths 5.0-6.0 mm (Fig. 70).

Carapace ( $a$ and $b)$ : with supraorbital spines, long slender lateral spines and very long posterior spine, the latter slightly longer than rostral spine and both with many small spinules, less prominent than in Stage I.

Abdomen: abdominal somites 2 and 3 with fixed lateral horns, somites $3-5$ with very long postero-lateral slender fixed spines, somite 6 with short ventro-lateral processes posteriorly. 


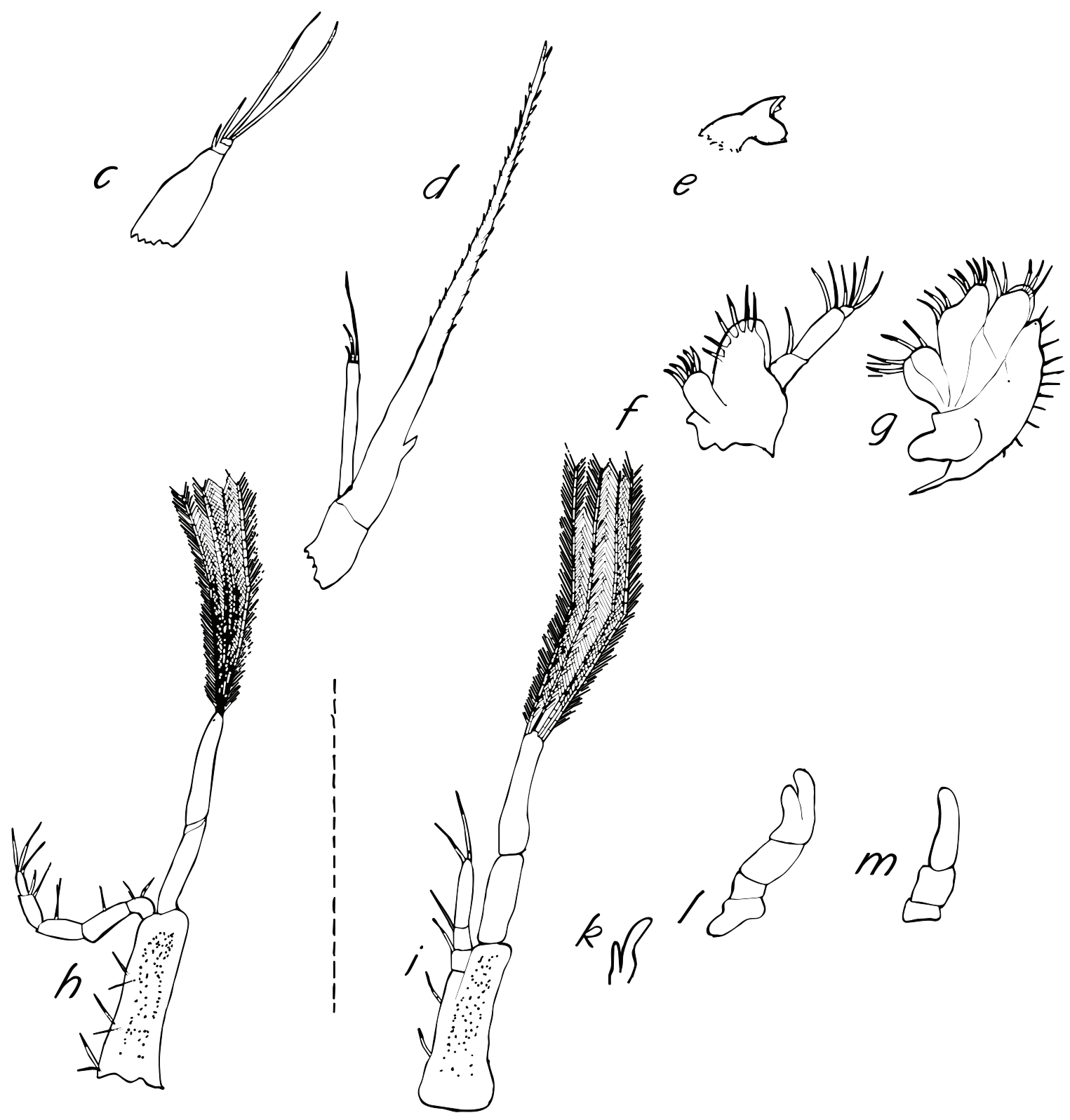

Fig. 69. Hyas coarctatus, Stage I Zoea: (c) antennule; (d) antenna; (e) mandible; (f) maxillule; (g) maxilla; (h) first maxilliped; (i) second maxilliped; (k) third maxilliped; (I) first pereopod; (m) second pereopod. Broken line = $1 \mathrm{~mm}$.

Antennule (c): short and stout with 2 distolateral projections, the first of which has a short seta, the other is possibly a bud of the ventromesial flagellum; apically 3 aesthetes.

Antenna (d): endopod is almost as long as exopod, the latter with an apical and 2 subapical spines. The protopodal process has fewer and smaller spinules than in Stage I and is almost as long as the rostrum.

Mandible (e): incisor is molar-like with two unequal cusps and separated from the molar which seems to lie behind it, a short one-segmented palp is present. 

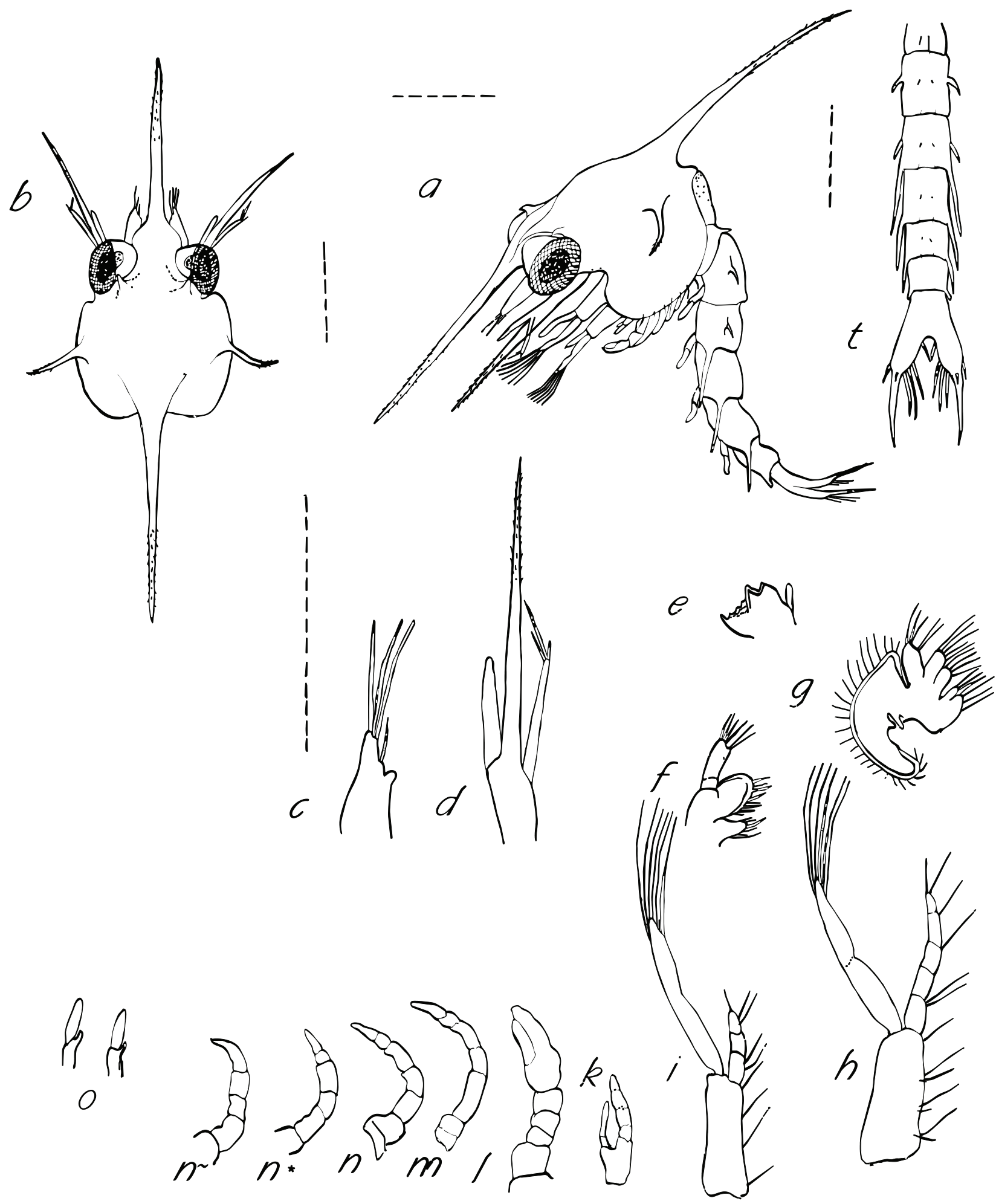

Fig. 70. Hyas coarctatus, Stage II Zoea: (a) whole zoea from left side; (b) dorsal carapace; (c) antennule; (d) antenna; (e) mandible; (f) maxillule; (g) maxilla; (h) first maxilliped; (i) second maxilliped; (k) third maxilliped; (I) first pereopod; (m) second pereopod; (n) 3rd-5th pereopods; (o) pleopod. Broken line $=1 \mathrm{~mm}$. 
Maxillule (f): proximal endite has about 6 spinous setae and is more slender than distal endite which bears about 4 strong and 3 lighter spines. Endopod is 2-segmented and has 4 apical and 2 subapical setae.

Maxilla (g): proximal endite with subequal and distal endite equal lobes. Endopod slightly longer than anterior lobe of scaphognathite,the latter subtriangular and shorter than curved posterior lobe, both fringed with about 25 setae.

First maxilliped (h): endopod with 5 divisions, exopod slightly longer and with 6 apical long setae.

Second maxilliped (i): endopod with 3 divisions and much shorter than exopod, the latter with 6 apical long setae.

Third maxilliped $(k)$ : much smaller than second with endopod obscurely divided and a short exopod.

Pereopods: first (I) stout and strongly chelate. The second to the fifth (m-n) are non-chelate, segmentation present but not clear.

Pleopods (o): uniramous, the endopod about as long as protopod, the latter with a distal projection laterally.

Telson ( $\mathrm{t}$ ): with a single short inner setae at each side near the fork and 3 long inner setae in a group at each side just before the fork narrows into a long spinous process, a single sutured outer spine is opposite the group of 3 at each side.

Date of occurrence in plankton hauls: infrequent, only on 19 August (Table 3).

\section{Megalopa}

No specimens of the megalopa were taken by the Calanus expeditions possibly because it may be the settling stage of this crab and would not be present in the plankton.

Pohle (1991) gives a description of the megalopa reared from the eggs of Hyas coarctatus alutaceus. 


\section{Remarks}

Although Ungava Bay appears to have incursions of Atlantic water (Dunbar, 1951; Fontaine, 1955; Squires, 1957), species of larval decapods taken in plankton hauls near the shore are not greatly different in composition of species than from more Arctic areas such as Hudson Bay (Squires, 1967). The number of species of larvae taken was few, only slightly more than half the numbers of species of adults (12 out of 20) taken benthonically by the same expeditions (Squires, 1957, 1966), although the larvae of one of these species, Sclerocrangon boreas, is non-planktonic. On the other hand the number of specimens of larvae taken were appreciable, amounting to almost 11000 (Tables 1-2), and $50-80 \%$ of the hauls took some decapods (Squires, 1957). The area may therefore be considered to be biologically productive in spite of the long winter season of ice cover and low ambient temperatures throughout the year. However, there appears to be moderation of temperatures by the incursions of Atlantic water and, in the inshore areas, by the influence of freshwater runoff from the large rivers such as the Koksoak, George and Whale Rivers (Fig. 1). Larvae were taken in larger numbers near rivers than elsewhere (Table 1). The appearance of Pandalus borealis and $P$. montagui, although few in numbers and from the eastern part of the bay, may be one of the best indications of Atlantic water incursions.

Argis dentata and Lebbeus groenlandicus, which have large robust larvae, occurred in greater numbers than other caridean shrimps in the plankton hauls (Table 2). However, more than half the specimens taken were larvae of Hyas coarctatus, a crab which produces large numbers of small eggs in a spawning.

\section{Occurrences of larval stages}

It is important to note only the larval stages that occurred in the plankton hauls of the MV CALANUS expeditions are described in this paper. Stage I Zoea of most species were present in the earliest (late-June) plankton hauls. A notable exception was Pandalus borealis which did not appear until mid to late-July. Some hipplolytid Stage II Zoea were also present in the earliest hauls, indicating that hatching of eggs had already occurred in early-June at the latest. Lebbeus groenlandicus had Stage II Zoea present from the earliest hauls and they continued to occur as late as early-August. Stage III Zoea did not appear until mid-July and Stage IV Zoea and Megalopa until August (an exception was Eualus fabricii which had Stage III Zoea present in June). In Hyas coarctatus the Stage I Zoea persisted from late-June until late-August, possibly indicating that hatching continued throughout the summer and Stage II Zoea appearing in August only.

\section{Taxonomic considerations}

In the genus Eualus, E. fabricii is easily separated from E. gaimardi (with dorsolateral spines on abdominal somite 5 only) by the presence of dorsolateral spines on somites 4 and 5 in zoeal Stages I-IV (Haynes, 1981; Table 6). Stage I Zoea of Eualus macilentus are much smaller than in these species (Ivanov, 1971): no larvae were taken in Ungava Bay although adults were present (Squires, 1957). Comparison with E. pusiolus (Pike and Williamson, 1961) is given in Table 7. The latter species does not extend as far north as Ungava Bay but is common in the Newfoundland area where there is an overlap in the distribution of both species (Squires, 1990).

Characteristics of Lebbeus groenlandicus compared with L. polaris indicate that the most recognizable difference is in the number of telson spines at similar larval Stages (Table 8), namely $11+11$ in the former and $9+9$ in the latter. Also the former is larger than the latter at similar larval Stages.

Spirontocaris phippsi and S. spinus are somewhat similar in size and appearance but may be separated by the following features (Table 9): telson spines in the former are not greatly different in size from each other while in the latter the centre pair is very small. Also, numbers of setae on the scaphognathite in S. phippsi are greater than in S. spinus at the same zoeal Stage. 
A summary of characteristics of larvae of Pandalus borealis and $P$. montagui (Table 4) shows a significant difference in size at similar zoeal Stages. Also antennal scale setae and scaphognathite setae are more numerous in $P$. borealis than in $P$. montagui at similar zoeal Stages. Incidentally P. borealis larvae appear smaller at earlier Stages than its congener, P. eous (formerly referred to as P. borealis) of the Pacific (Squires, 1992). Although other pandalids were not taken in Ungava Bay, Pandalus propinquus and Dichelopandalus are included in the summary (Table 5) from relevant literature for comparison with the two former species.

Comparison of Argis dentata and Crangon septemspinosa (Table 7) shows that they are greatly different in size and development at similar zoeal Stages. $C$. septemspinosa does not occur north of the Straits of Belle Isle but there is considerable overlap with the distribution of $A$. dentata which extends as far south as the Bay of Fundy, Canada (Squires, 1990).

Pagurus pubescens, the only hermit crab that occurs in Ungava Bay, is compared with $P$. acadianus (Table 11) since there is an overlap of the distribution of both species south of the Straits of Belle Isle (Squires, 1990). P. acadianus is somewhat smaller than P. pubescens at the same stage, and has a styliform instead of a bifid antennal flagellum.

A similar situation applies with two species of Hyas (Table 12), where H. coarctatus only occurs in Ungava Bay (Pohle, 1991 believes these larvae to belong to the subspecies H. C. alutaceus). Its larvae are somewhat larger than those of $H$. araneus in Europe (Christiansen, 1973) at the same stage, and it has a greater number of setae on the lobes of the scaphognathite.

There may be some question as to whether H. c. alutaceus, a Pacific species, extends across the Arctic and into the Northwest Atlantic. Adult specimens were taken in the Beaufort Sea at Franklin Bay (Squires, 1968) but not further east in surveys of 1960-65. The distribution of larvae eastward is mediated against by westward currents along the coast (Grosvenor and Darley, 1963). Nor were any taken further eastward at the Queen Elizabeth and nearby islands during 1962 (Squires, 1969).

\section{Evolutionary considerations}

Various authors indicate that species of decapods show evolutionary advancement by loss of larval stages or abbreviated development, and loss of appendages. In the present group of species, therefore, the less highly evolved appear to be the pandalids with the genus Pandalus retaining exopods on three of the pereopods and having several larval Stages. Among the hippolytids, however, the genus Eualus also retains an exopod on three pereopods, but the genus Spirontocaris has an exopod on two pereopods, and the genus Lebbeus has no exopod on any pereopod. Lebbeus also has more abbreviated development, the species $L$. groenlandicus having only three zoeal Stages instead of four as in other species. Species in the family of crangonids appear to be the most advanced among these caridean shrimps: no exopods are present on the pereopods and there is abbreviated development as in Argis with only three zoeal Stages. In one species, Sclerocrangon boreas, there is a further adaptation in which the larvae do not hatch into the plankton but remain clinging to the mother until they reach a settling stage, possibly the first juvenile.

The anomurans or hermit crabs, and the brachyurans, the true crabs, show more advanced evolutionary characteristics such as a reduced third maxilliped as well as no exopods on pereopods, and the brachyurans, Hyas spp., have in addition a modified antenna with reduced endopod and exopod. 


\section{References}

BERKELEY, A. A. 1930. The post-embryonic development of the common pandalids of British Columbia. Contrib. Can. Biol., 6: 79-163.

BULL, H. O. 1938. The newly-hatched larva of Spirontocaris pusiola (Krøyer). Rept. Dove Mar. Lab., 3rd Series No. 6: 4345.

CHAPUT, G. J. 1984. Distribution and abundance of decapod larvae with special emphasis on the distribution, abundance and development of Pandalus borealis. LGL report to Dept. of Fisheries and Oceans, $64 \mathrm{p}$.

CHRISTIANSEN, M. E. 1973. The complete larval development of Hyas araneus (Linnaeus) and Hyas coarctatus Leach (Decapoda, Brachyura, Majidae) reared in the laboratory. Norw. J. Zool., 21: 63-89.

DUNBAR, M. J. 1951. Eastern Arctic waters. Bull. Fish. Res. Board. Can., 88: 131 p.

DUNBAR, M. J. and E. H. GRAINGER. 1952. Station list of the "Calanus" Expeditions, 1947-50. J. Fish. Res. Board. Can., 9: 65-82.

FONTAINE, M. 1955. The planktonic copepods (Calanoida, Cyclopoida, Monstrilloida) of Ungava, Bay with special reference to the biology of Pseudocalanus minutus and Calanus finmarchicus. J. Fish. Res. Board. Can., 12: 858-898.

GRAINGER, E. H. 1954. Station list of the Calanus expeditions, 1951-52, together with Frobisher Bay stations, 1948,1950 and 1951, and Resolution Island stations, 1950. J. Fish. Res. Bd. Can., 11: 98-105.

GROSVENOR, M. B. [Ed.] and J. M. DARLEY [Cartographer]. 1963. National Geographic Atlas of the World. Natl. Geogr. Soc., Washington, D. C., 300 p.

GURNEY, R. 1942. Larvae of decapod Crustacea. Ray Society, London, 306 p.

HART, J. F. L. 1937. Larval and adult stages of British Columbia Anomura. Can. J. Res. (D), 15: 179-220, Fig. 1-11, PI. I. 1971. Key to planktonic larvae of families of decapod Crustacea of British Columbia. Syesis, 4: 227-234.

HAYNES, E. 1978. Description of larvae of a hippolytid shrimp, Lebbeus groenlandicus, reared in situ in Kachemak Bay, Alaska. Fish. Bull. U.S., 76: 457-465.

1979. Description of larvae of the Northern Shrimp, Pandalus borealis, reared in situ in Kachemak Bay, Alaska. Fish. Bull. U.S., 77: 157-173.

1980. Larval morphology of Pandalus tridens and a summary of the principal morphological characteristics of North Pacific pandalid shrimp larvae. Fish. Bull. U.S., 77: 625-640.

1981. Early zoeal stages of Lebbeus polaris, Eualus suckleyi, E. fabricii, Spirontocaris arcuata, S. ochotensis and Heptacarpus camtschaticus (Crustacea,Decapoda, Caridea, Hippolytidae) and morphological characterization of zoeae of Spirontocaris and related genera. Fish. Bull. U.S., 79: 421-440.

1985. Morphological development, identification, and biology of larvae of Pandalidae, Hippolytidae, and Crangonidae (Crustacea, Decapoda) of the northern North Pacific Ocean. Fish. Bull. U.S., 83: 253-288.

IVANOV, B. G. 1971. The larvae of some eastern shrimps in relation to their taxonomic status. Zool. Zh., 50: 657-665. (In Russian, English summary).

LEBOUR, M. V. 1928. The larval stages of the Plymouth Brachyura. Proc. Zool. Soc. Lond., 1928, p. 473-560. PIs. I-XVI. 1931. The larvae of the Plymouth Caridea. I. The larvae of the Crangonidae. II. The larvae of the Hippolytidae. Proc. Zool Soc. Lond., 101: 1-9, Pls. I-III.

1937. The newly hatched larva of Spirontocaris spinus (Sowerby) var. lilljeborgi Danielssen. J. Mar. Biol. Assoc. U.K., 22: 101-104.

1940. The larvae of the Pandalidae. J. Mar. Biol. Assoc. U.K., 24: 239-252.

MACDONALD, J. D., R. B. PIKE, and D. I. WILLIAMSON. 1957. Larvae of the British species of Diogenes, Pagurus, Anapagurus and Lithodes (Crustacea, Decapoda). Proc. Zool. Soc. Lond., 128: 209-257.

MAKAROV, R. R. 1966. Larvae of shrimps, hermit crabs and crabs of the west Kamchatkan shelf and their distribution. Izdatelystvo "Nauka", 164 p. (In Russian).

MAKAROV, V. V. 1935. Beschriebung neuer Dekapoden-formen aus den Fernen Ostens. Zool. Anz., 109: 319-325.

MCLAUGHLIN, P. A., and R. H. GORE. 1988. Studies on the Provenzanoi mclaughlinae Garcia-Gomez, 1982 (Decapoda: Anomura: Paguridae), reared under laboratory conditions. J. Crustacean Biol., 8: 262-282.

NEEDLER, A. A. BERKELEY. 1941. Larval stages of Crangon septemspinosa Say. Trans. Roy. Can. Inst., 50. 23: $193-199$.

PIKE, R. B., and D. I. WILLIAMSON. 1960. Larvae of Decapod Crustacea of the families Diogenidae and Paguridae from the Bay of Naples. Pubbl. Stn. Zool. Napoli, 31: 493-552.

1961. The larvae of Spirontocaris and related genera (Decapoda Hippolytidae). Crustaceana, 2: 187-208.

1964. The larvae of some species of Pandalidae (Decapoda). Crustaceana, 6: 265-284.

POHLE, G. W. 1991. Larval development of Canadian Atlantic oregoniid crabs (Brachyura: Majidae), with emphasis on Hyas coarctatus alutaceus Brandt, 1851, and a comparison with Atlantic and Pacific conspecifics. Can. J. Zool., 69: 2717-2737.

POHLE, G., and M. TELFORD. 1981. Morphology and classification of decapod crustacean setae: a scanning electron microscope study of Dissodactylus crinitichelis Moreira, 1901 (Brachyura: Pinnotheridae). Bull. Mar. Sci., 31: 736-752.

ROBERTS, M. H., Jr. 1968. Functional morphology of the mouthparts of the hermit crabs, Pagurus longicarpus and $P$. pollicaris. Chesapeake Sci., 9: 9-20.

1973. Larval development of Pagurus acadianus Benedict, 1901, reared in the laboratory (Decapoda, Anomura). Crustaceana, 24: 303-317.

SARS, G. O. 1890. Bidrag til Kunduskaben om Decapodernes Forvandlinger. III. Crangonidae. Arch. f. Math. og Naturvid., 14: $182-195$.

1900. Account of the postembryonal development of Pandalus borealis Krøyer with remarks on the development of other Pandali and description of the adult Pandalus borealis. Rept. Norweg. Fish. Mar. Invest., 1: 1-45. 
SQUIRES, H. J. 1957. Decapod Crustacea of the Calanus Expeditions in Ungava Bay, 1947 to 1950. Can. J. Zool., 35: 463494.

1965. Larvae and megalopa of Argis dentata (Crustacea: Decapoda) from Ungava Bay. J. Fish. Res. Board. Can., 22: 69-82.

1966. Distribution of decapod Crustacea in the Northwest Atlantic. Amer. Geogr. Soc. Ser. Atlas Mar. Environ., Folio 12: 1-4, Pls. 1-4.

1967. Decapod Crustacea from CALANUS expeditions in Hudson Bay in 1953, 1954 and 1958-61. J. Fish. Res. Board. Can., 24: 1873-1903.

1968. Decapod Crustacea from the Queen Elizabeth and nearby islands in 1962. J. Fish. Res. Board. Can., 25: 347-362.

1969. Decapod Crustacea of the Beaufort Sea and arctic waters eastward to Cambridge Bay, 1960-65. J. Fish. Res. Board. Can., 26: 1899-1918.

1990. Decapod Crustacea of the Atlantic coast of Canada. Can. Bull. Fish. Aquat. Sci., 221: 532 p.

1992. Recognition of Pandalus eous Makarov, 1935 as a Pacific species not a variety of the Atlantic Pandalus borealis Krøyer, 1838. Crustaceana, 63: 257-262.

WIENBERG, R. MS 1975. Studies on laboratory-reared larvae of Pandalus borealis Krøyer: larval development, growth and feeding under different temperature, salinity, light and food conditions. ICES C.M. Doc., No. K:15, 25 p.

WILLIAMSON, D. I. 1960. Crustacea Decapoda: Iarvae VII. Caridea, Family Crangonidae, Stenopodidea. Fiches Identif.. Zooplankton, 90: 1-5. 
Tables 1-12 
TABLE 1. Numbers of decapod larvae taken at Stations in Ungava Bay during the MV CALANUS Expeditions, 1947-51 (for precise positions see maps in Dunbar and Grainger, 1952 and Grainger, 1954).

\begin{tabular}{|c|c|c|c|c|c|}
\hline Date & $\begin{array}{c}\text { Station } \\
\text { No. }\end{array}$ & Lat Long & Location & Depth ${ }^{1}$ (hauls) & Specimens \\
\hline \multicolumn{6}{|c|}{1947} \\
\hline 24 Jun & 1 & $58^{\circ} 39 \mathrm{~N} 68^{\circ} 15 \mathrm{~W}$ & Koksoak River mouth & $4-5(2)$ & 431 \\
\hline 29 Jun & 3 & $58^{\circ} 55 \mathrm{~N} 68^{\circ} 13 \mathrm{~W}$ & Koksoak River mouth & $2-7(3)$ & 1346 \\
\hline $03 \mathrm{Jul}$ & 7 & $58^{\circ} 55 \mathrm{~N} 68^{\circ} 53 \mathrm{~W}$ & Koksoak River mouth & $5-10(3)$ & 388 \\
\hline $11 \mathrm{Jul}$ & 9 & $59^{\circ} 02 \mathrm{~N} 68^{\circ} 54 \mathrm{~W}$ & Leaf Bay & $8-17(3)$ & 406 \\
\hline $13 \mathrm{Jul}$ & 13 & $59^{\circ} 30 \mathrm{~N} 69^{\circ} 00 \mathrm{~W}$ & Hopes Advance Bay & $4-41(5)$ & 83 \\
\hline $17 \mathrm{Jul}$ & 18 & $60^{\circ} 02 \mathrm{~N} 69^{\circ} 03 \mathrm{~W}$ & East of Tuvalik & $16-51(3)$ & 35 \\
\hline $18 \mathrm{Jul}$ & 22 & $59^{\circ} 18 \mathrm{~N} 68^{\circ} 57 \mathrm{~W}$ & Inuksulik & $2-5(2)$ & 424 \\
\hline 20 Jul & 1 & $58^{\circ} 39 \mathrm{~N} 68^{\circ} 15 \mathrm{~W}$ & Koksoak River mouth & $3-21(6)$ & 1013 \\
\hline 10 Aug & 33 & $59^{\circ} 13 \mathrm{~N} 65^{\circ} 45 \mathrm{~W}$ & Keglo Bay & $7-13(2)$ & 364 \\
\hline 11 Aug & 37 & $59^{\circ} 05 \mathrm{~N} 65^{\circ} 45 \mathrm{~W}$ & Keglo Bay & $0-1(1)$ & 30 \\
\hline 17 Aug & 41 & 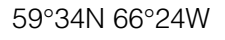 & West of Adlorilik & $52(1)$ & 3 \\
\hline 19 Aug & 44 & $60^{\circ} 23 \mathrm{~N} 64^{\circ} 50 \mathrm{~W}$ & Forbes Sound & $0-77(3)$ & 465 \\
\hline 20 Aug & 43 & $60^{\circ} 24 \mathrm{~N} 64^{\circ} 50 \mathrm{~W}$ & Port Burwell Harbor & $0-4(4)$ & 192 \\
\hline \multicolumn{6}{|c|}{1948} \\
\hline $10 \mathrm{Jul}$ & 53 & $58^{\circ} 38 \mathrm{~N} 68^{\circ} 13 \mathrm{~W}$ & Koksoak River mouth & $0-9(1)$ & 106 \\
\hline $14 \mathrm{Jul}$ & 54 & $58^{\circ} 55 \mathrm{~N} 68^{\circ} 53 \mathrm{~W}$ & Leaf Bay & $0(1)$ & 113 \\
\hline $24 \mathrm{Jul}$ & 56 & $58^{\circ} 37 \mathrm{~N} 67^{\circ} 06 \mathrm{~W}$ & Whale River & $0(1)$ & 175 \\
\hline 27 Jul & 57 & $59^{\circ} 21 \mathrm{~N} 66^{\circ} 00 \mathrm{~W}$ & NW of Keglo Bay & $7-40(3)$ & 285 \\
\hline 02 Aug & 60 & $60^{\circ} 20 \mathrm{~N} 64^{\circ} 41 \mathrm{~W}$ & Young Inlet, Burwell & $0-15(2)$ & 85 \\
\hline 04 Aug & 62 & $60^{\circ} 29 \mathrm{~N} 64^{\circ} 44 \mathrm{~W}$ & Bush and Killinek Island & $8-10(2)$ & 123 \\
\hline 16 Aug & 63 & $60^{\circ} 23 \mathrm{~N} 64^{\circ} 49 \mathrm{~W}$ & Forbes Sound & $0(1)$ & 10 \\
\hline \multicolumn{6}{|c|}{1949} \\
\hline 26 Jun & 101 & $58^{\circ} 52 \mathrm{~N} 66^{\circ} 23 \mathrm{~W}$ & Beacon Island, George River & $73-233(2)$ & 510 \\
\hline $06 \mathrm{Jul}$ & 103 & $60^{\circ} 24 \mathrm{~N} 64^{\circ} 58 \mathrm{~W}$ & Jackson Island, W. Burwell & 110-200 (2) & 127 \\
\hline $07 \mathrm{Jul}$ & 106 & $60^{\circ} 21 \mathrm{~N} 64^{\circ} 50 \mathrm{~W}$ & Cape William Smith & $10-14(1)$ & 481 \\
\hline $14 \mathrm{Jul}$ & 103 & $60^{\circ} 24 \mathrm{~N} 64^{\circ} 58 \mathrm{~W}$ & Jackson Island, W. Burwell & $44-116(2)$ & 13 \\
\hline 07 Aug & 103 & $60^{\circ} 24 \mathrm{~N} 64^{\circ} 58 \mathrm{~W}$ & Jackson Island, W. Burwell & $5-10(1)$ & 498 \\
\hline 10 Aug & 123 & $60^{\circ} 40 \mathrm{~N} 64^{\circ} 42 \mathrm{~W}$ & Button Islands & $0-15(4)$ & 443 \\
\hline 20 Aug & 124 & $59^{\circ} 25 \mathrm{~N} 69^{\circ} 00 \mathrm{~W}$ & Inuksulik & $0(1)$ & 322 \\
\hline \multicolumn{6}{|c|}{1950} \\
\hline 28 Jun & $201 C$ & $59^{\circ} 30 \mathrm{~N} 65^{\circ} 21 \mathrm{~W}$ & Adlorilik & $1-20(2)$ & 185 \\
\hline $15 \mathrm{Jul}$ & 206 & $60^{\circ} 45 \mathrm{~N} 69^{\circ} 17 \mathrm{~W}$ & Imilik & $3(1)$ & 6 \\
\hline 20 Jul & 209 & $61^{\circ} 10 \mathrm{~N} 69^{\circ} 33 \mathrm{~W}$ & Cape Hopes Advance & $75(1)$ & 22 \\
\hline $21 \mathrm{Jul}$ & 211 & $61^{\circ} 03 \mathrm{~N} 69^{\circ} 42 \mathrm{~W}$ & Diana Bay, Koaktuk & $0-1(2)$ & 59 \\
\hline 03 Aug & 222 & $62^{\circ} 45 \mathrm{~N} 69^{\circ} 41 \mathrm{~W}$ & Lake Harbour & $1-8(2)$ & 63 \\
\hline 03 Aug & 223 & $62^{\circ} 43 \mathrm{~N} 69^{\circ} 37 \mathrm{~W}$ & Lake Harbour & $7(1)$ & 474 \\
\hline 25 Aug & 228 & $58^{\circ} 52 \mathrm{~N} 66^{\circ} 28 \mathrm{~W}$ & Beacon Island, George River & $0(1)$ & 2 \\
\hline 26 Aug & 230 & $59^{\circ} 30 \mathrm{~N} 65^{\circ} 18 \mathrm{~W}$ & Adlorilik & $12-18(1)$ & 4 \\
\hline 27 Aug & 231 & $59^{\circ} 29 \mathrm{~N} 65^{\circ} 15 \mathrm{~W}$ & Adlorilik & $5-57(3)$ & 168 \\
\hline 28 Aug & $201 C$ & $59^{\circ} 30 \mathrm{~N} 65^{\circ} 21 \mathrm{~W}$ & Adlorilik & $13-87(2)$ & 569 \\
\hline 31 Aug & 234 & $59^{\circ} 31 \mathrm{~N} 65^{\circ} 45 \mathrm{~W}$ & Adlorilik & $62-85(2)$ & 63 \\
\hline \multicolumn{6}{|c|}{1951} \\
\hline $28 \mathrm{Jul}$ & 273 & & Lake Harbour & $0-21(1)$ & 1 \\
\hline $03 \mathrm{Jul}$ & 301 & $59^{\circ} 30 \mathrm{~N} 65^{\circ} 20 \mathrm{~W}$ & Adlorilik & $110(1)$ & 849 \\
\hline \multicolumn{5}{|c|}{ Decapods, Total } & 10936 \\
\hline
\end{tabular}


TABLE 2. Numbers of various species of decapod crustacean larvae taken during the MV CALANUS Expeditions, 1947-51.

\begin{tabular}{|c|c|c|c|c|c|c|}
\hline \multirow[b]{2}{*}{ Species } & \multicolumn{5}{|c|}{ No. of specimens at Stages } & \multirow[b]{2}{*}{ Total } \\
\hline & I & II & III & IV & Megalopa & \\
\hline Eualus fabricii & 19 & 28 & 7 & 3 & 4 & 61 \\
\hline Eualus gaimardi & 56 & 22 & 8 & 6 & $\dagger$ & 92 \\
\hline Lebbeus groenlandicus & 9 & 356 & 95 & * & 397 & 857 \\
\hline Lebbeus polaris & 1 & 14 & 2 & 3 & 8 & 28 \\
\hline Spirontocaris phippsi & 183 & 81 & 44 & 37 & $\dagger$ & 345 \\
\hline Spirontocaris spinus & 236 & 313 & 58 & 43 & 5 & 655 \\
\hline Pandalus borealis & 1 & 2 & 16 & 3 & $\dagger$ & 22 \\
\hline Pandalus montagui & 22 & 32 & 12 & 3 & $\dagger$ & 69 \\
\hline Argis dentata & 1164 & 625 & 1 & * & 3 & 1793 \\
\hline Sabinea septemcarinata & 38 & 8 & 1 & 7 & $\dagger$ & 54 \\
\hline Pagurus pubescens & 665 & 254 & 391 & 32 & $\dagger$ & 1342 \\
\hline \multirow[t]{2}{*}{ Hyas coarctatus } & 5214 & 413 & * & * & $\dagger$ & 5618 \\
\hline & \multicolumn{5}{|c|}{ Grand Total Counted } & 10936 \\
\hline
\end{tabular}

$\dagger=$ not taken; * does not exist.

TABLE 3. Dates of occurrence in plankton hauls of larval Stages of various species of decapod crustaceans in Ungava Bay, 1947-51.

\begin{tabular}{|c|c|c|c|c|c|}
\hline Species & Stage I & Stage II & Stage III & Stage IV & Megalopa \\
\hline E. fabricii & 26 Jun to $07 \mathrm{Jul}$ & 26 Jun to $20 \mathrm{Jul}$ & 26 Jun to 27 Aug & 20-27 Aug & 20-27 Aug \\
\hline E. gaimardi & 29 Jun to $14 \mathrm{Jul}$ & 26 Jun to $07 \mathrm{Jul}$ & $14 \mathrm{Jul}$ to 26 Aug & 19-26 Aug & - \\
\hline L. groenlandicus & 26 Jun to $07 \mathrm{Jul}$ & 24 Jun to 25 Aug & - & - & 10-20 Aug \\
\hline L. polaris & - & 14 Jul to 26 Aug & 26 Aug & $20 \mathrm{Jul}$ to $19 \mathrm{Aug}$ & 14-20 Aug \\
\hline S. phippsi & 26 Jun to $14 \mathrm{Jul}$ & $13 \mathrm{Jul}$ to 03 Aug & $20 \mathrm{Jul}$ to 27 Aug & 26 Aug & \\
\hline S. spinus & 03-20 Jul & $29 \mathrm{Jun}$ to $27 \mathrm{Jul}$ & $13 \mathrm{Jul}$ to Aug 03 & 10-28 Aug & 10 Aug \\
\hline P. borealis & 11-27 Jul & 14-27 Jul & Jul 20 to Aug 27 & 03-25 Aug & - \\
\hline P. montagui & 24 Jun to $20 \mathrm{Jul}$ & 03 Jul to 26 Aug & 17-28 Aug & 26-28 Aug & - \\
\hline A. dentata & 24 Jun to $14 \mathrm{Jul}$ & $10 \mathrm{Jul}$ to $07 \mathrm{Aug}$ & - & - & 11-20 Aug \\
\hline S. septemcarinata & $03 \mathrm{Jul}$ & 13-20 Jul & 03 Aug & 14-27 Aug & 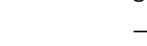 \\
\hline P. pubescens & 24 Jun & 24 Jun to $20 \mathrm{Jul}$ & 13 Jul to 04 Aug & 14-27 Aug & - \\
\hline H. coarctatus & 24 Jun to 20 Aug & 19 Aug & - & - & _ \\
\hline
\end{tabular}


TABLE 4. Summary of characteristics of larvae of Eualus fabricii and Eualus gaimardi from present observations and Haynes (1985) and Pike and Williamson (1964).

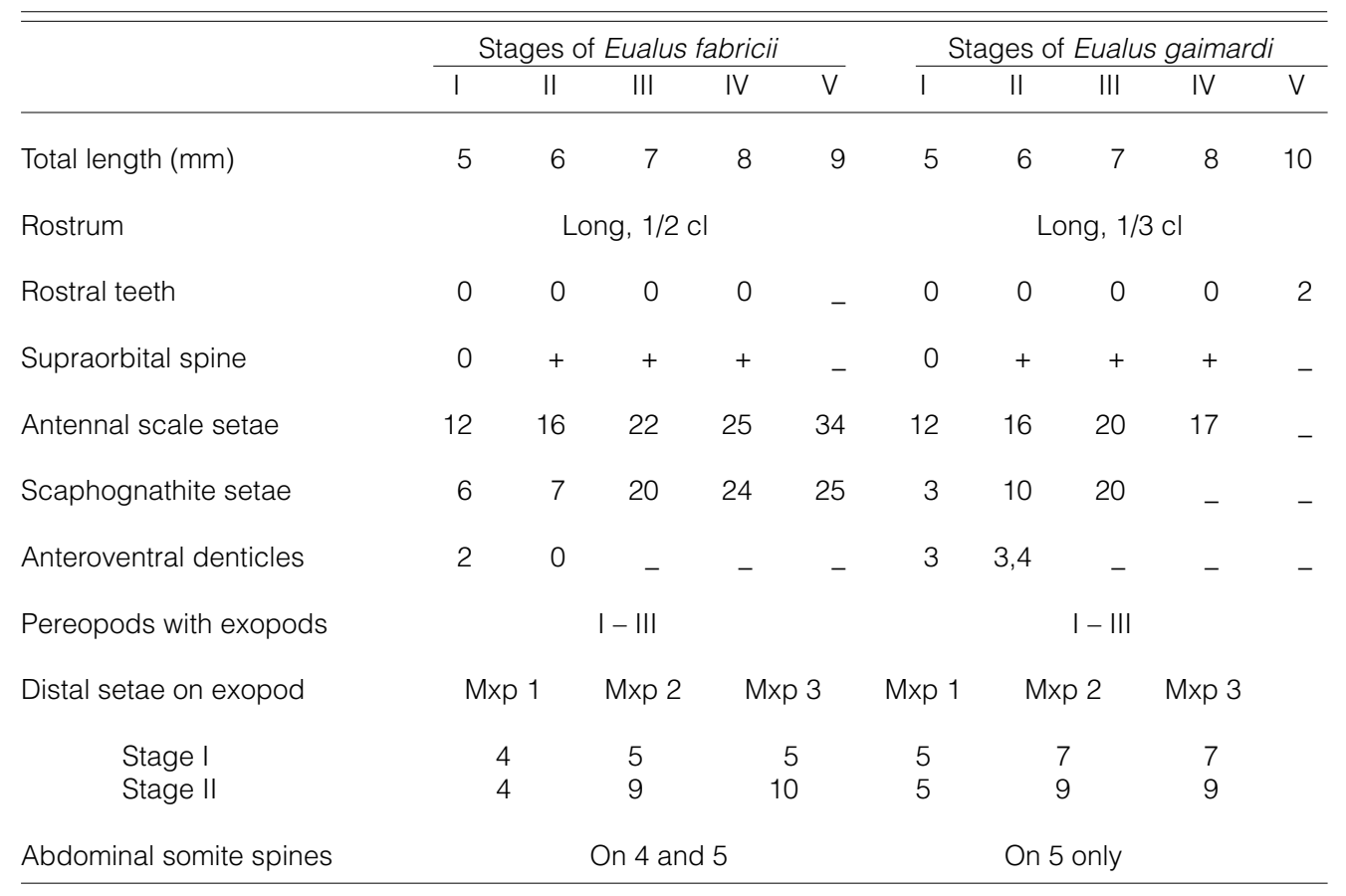

TABLE 5. Summary of characteristics of larvae of Eualus macilentus from Ivanov (1971) and Eualus pusiolus from Bull (1938).

\begin{tabular}{|c|c|c|c|c|c|c|c|c|c|c|}
\hline & \multicolumn{5}{|c|}{ Stages of Eualus macilentus } & \multicolumn{5}{|c|}{ Stages of Eualus pusiolus } \\
\hline & I & II & III & IV & V & I & II & III & IV & V \\
\hline Total lengths (mm) & 3 & & & & & 2 & & & & \\
\hline Rostrum & small & & & & & $\begin{array}{l}\text { small } \\
\text { spine }\end{array}$ & & & & \\
\hline Anterolateral denticles & 4 & & & & & 3 & & & & \\
\hline Ant. and post. tubercles & & & & & & + & & & & \\
\hline Antennal scale setae & & & & & & 8 & & & & \\
\hline Antennal scale segments & & & & & & 5 & & & & \\
\hline Spines on abd. somites & & & & & & 0 & & & & \\
\hline Scaphognathite setae & & & & & & $3+2$ & & & & \\
\hline \multicolumn{11}{|l|}{ Setae on exopods of } \\
\hline Maxilliped I & 4 & & & & & 5 & & & & \\
\hline Maxilliped II & 5 & & & & & 5 & & & & \\
\hline Maxilliped III & 5 & & & & & 5 & & & & \\
\hline Telson spines terminal & $7+7$ & & & & & $6+6$ & & & & \\
\hline Pereopods - exopods & $|-|||$ & & & & & $|-|||$ & & & & \\
\hline Pleopods & & & & & & & & & & \\
\hline
\end{tabular}


TABLE 6. Summary of characteristics of larvae of Lebbeus groenlandicus and Lebbeus polaris from present observations and Haynes (1985) and Pike and Williamson (1964).

\begin{tabular}{|c|c|c|c|c|c|c|c|c|}
\hline & \multicolumn{4}{|c|}{ Stages of Lebbeus groenlandicus } & \multicolumn{4}{|c|}{ Stages of Lebbeus polaris } \\
\hline & I & II & III & Megalopa & I & II & III & Megalopa \\
\hline Total length (mm) & $8-9$ & $8-11$ & $9-11$ & $8-11$ & $6-7$ & $7-8$ & $8-9$ & $9-10$ \\
\hline Rostrum & \multicolumn{3}{|c|}{$\begin{array}{l}\text { Long, } 2 / 3 \mathrm{cl} \text {, equal } \\
\text { to eye-stalk }\end{array}$} & Short thick & \multicolumn{3}{|c|}{ Styliform, 1/2 cl. } & Short \\
\hline Supraorbital spine & 0 & + & + & + & - & + & + & + \\
\hline Ant. and post. tubercle & + & + & + & 0 & + & + & + & - \\
\hline Antennal scale setae & $9-11$ & 25 & - & 37 & 11 & 35 & 30 & 48 \\
\hline Anteroventral denticles & 3 & 3 & - & 0 & - & 0 & 0 & 0 \\
\hline Scaphognathite setae & $29+1$ & $35+3$ & - & $30+5$ & $25+1$ & 30 & 25 & $33+7$ \\
\hline Pereopods with exopods & \multicolumn{4}{|c|}{0 (but small lobe in I) } & \multicolumn{3}{|c|}{0 (but small lobe in I) } & \\
\hline Abdominal somite spines & \multicolumn{3}{|c|}{4,5} & & \multicolumn{3}{|c|}{4,5} & \\
\hline Pleopods & \multicolumn{3}{|c|}{ Bilobed, with a.i. in I } & & \multicolumn{3}{|c|}{ Bilobed, with a.i. in II } & \\
\hline Telson spines & $11+11$ & $11+11$ & - & $3+3$ & $9+9$ & $9+9$ & - & $2+4+2$ \\
\hline
\end{tabular}

TABLE 7. Summary of characteristics of larvae of Spirontocaris phippsi and Spirontocaris spinus from present observations and Haynes (1985) and Pike and Williamson (1964).

\begin{tabular}{|c|c|c|c|c|c|c|c|c|c|c|}
\hline & \multicolumn{5}{|c|}{ Stages of Spirontocaris phippsi } & \multicolumn{5}{|c|}{ Stages of Spirontocaris spinus } \\
\hline & I & II & III & IV & V & I & II & III & IV & V \\
\hline Total length (mm) & 6 & 8 & 9 & 10 & - & 5 & 7 & 8 & 9 & _ \\
\hline Supraorbital spine & + & + & + & + & + & + & + & + & + & + \\
\hline Ant. and post. tubercle & \multicolumn{5}{|c|}{ Both present } & \multicolumn{5}{|c|}{ Both present } \\
\hline Anteroventral dent. & 0 & 0 & 0 & 0 & 0 & 4 & 4 & 3 & 0 & 0 \\
\hline Antennal setae & 11 & 29 & - & 25 & - & 10 & 21 & 16 & 30 & - \\
\hline Scaphognathite setae & 35 & 37 & 31 & 32 & - & 4 & 10 & 10 & 20 & 20 \\
\hline Pereopod exopods & \multicolumn{5}{|c|}{$|-| \mid$} & \multicolumn{5}{|c|}{$|-| \mid$} \\
\hline Abd. somite spines & \multicolumn{5}{|c|}{ On 4 and 5} & \multicolumn{5}{|c|}{ On 4 with tuft of setae, and 5} \\
\hline Telson spines & $7+7$ & $8+8$ & & & & $7+7$ & $8+8$ & tre $p$ & y small & \\
\hline
\end{tabular}


TABLE 8. Summary of characteristics of larvae of Pandalus borealis and Pandalus montagui from present observations and from Pike and Williamson (1964) and Wienberg (MS 1975).

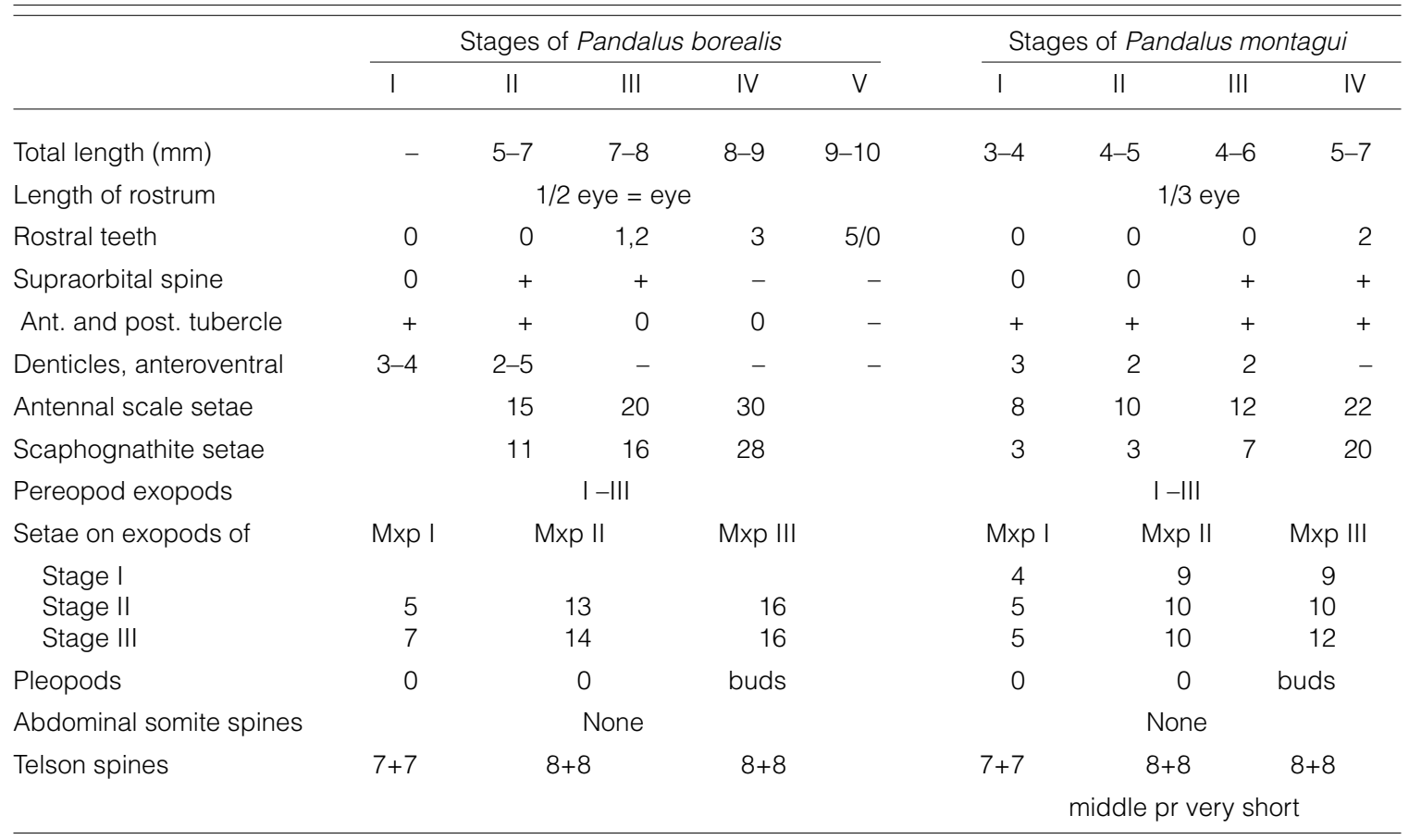

TABLE 9. Summary of characteristics of larvae of Dichelopandalus bonnieri and Pandalus propinquus (Pike and Williamson (1964), and Lebour (1940)).

\begin{tabular}{|c|c|c|c|c|c|c|c|c|c|c|}
\hline & \multicolumn{5}{|c|}{ Stages of Pandalus propinquus } & \multicolumn{5}{|c|}{ Stages of Dichelopandalus bonnieri } \\
\hline & I & II & III & IV & $\overline{\mathrm{V}}$ & I & II & III & IV & $\mathrm{V}$ \\
\hline Total length (mm) & 4 & 5 & 7 & 9 & 11 & 5 & 6 & 8 & 10 & 12 \\
\hline Supraorbital spine & \multicolumn{5}{|c|}{ Present in all stages } & \multicolumn{5}{|c|}{ Present in all stages } \\
\hline Rostral teeth & 0 & 0 & 3 & 7 & 9 & 0 & 1 & 3 & 7 & 9 \\
\hline Ant. and post. tuberc & \multicolumn{5}{|c|}{ Both present } & \multicolumn{5}{|c|}{ Anterior only } \\
\hline Denticles, anterovent & \multicolumn{5}{|c|}{ Present, 4, 5} & \multicolumn{5}{|c|}{ Present, 6-8 (larger) } \\
\hline Antennal scale setae & & & & & & 10 & 20 & 25 & 25 & 25 \\
\hline Pereopod exopods & \multicolumn{5}{|c|}{$|-|||$} & \multicolumn{5}{|c|}{$|-| I \mid$} \\
\hline \multicolumn{2}{|l|}{ Setae on exopods } & Mxp I & Mxp II & & Mxp III & & Mxp I & Mxp II & \multicolumn{2}{|c|}{ Mxp III } \\
\hline \multicolumn{2}{|l|}{ Stage I } & 4 & 5 & & 5 & & 4 & \multicolumn{2}{|l|}{5} & 5 \\
\hline \multicolumn{2}{|l|}{ Pleopods } & 0 & Buds & & Buds & & 0 & \multicolumn{2}{|l|}{ Buds } & Buds \\
\hline \multicolumn{2}{|c|}{ Abdominal somite spines } & \multicolumn{4}{|c|}{ On 5th only } & & \multicolumn{4}{|c|}{ On 5th only } \\
\hline Somite denticles on & 4,5 & 4,5 & - & - & - & 3,4 & - & - & - & - \\
\hline Dorsal carina on 3rd & \multicolumn{5}{|c|}{ Present (larger) } & \multicolumn{5}{|c|}{ Present } \\
\hline Telson spines & $7+7$ & $8+8$ & & & & $7+7$ & $8+8$ & & & \\
\hline
\end{tabular}


TABLE 10. Summary of characteristics of larvae of Argis dentata from Squires (1964) and Crangon septemspinosa from Needler (1941).

\begin{tabular}{|c|c|c|c|c|c|c|c|c|c|c|}
\hline & \multicolumn{5}{|c|}{ Stages of Argis dentata } & \multicolumn{5}{|c|}{ Stages of Crangon septemspinosa } \\
\hline & I & II & III & IV & $\bar{M}$ & I & II & III & IV & M \\
\hline Total length (mm) & 9 & 10 & & & 12 & 2 & 2.2 & 3 & 3.5 & 4 \\
\hline Supraorbital spines & 0 & 0 & & & 0 & 0 & 0 & 0 & 0 & 0 \\
\hline Ant. or post. tubercles & 0 & 0 & & & 0 & 0 & 0 & 0 & 0 & 0 \\
\hline Denticles, anteroventral & 3 & 2 & & & 0 & 3 & 2 & 2 & 0 & 0 \\
\hline Antennular segments & 3 & 3s & & & $3 s$ & 1 & 3 & 3 & $3 s$ & $3 s$ \\
\hline Antennal scale setae & 20 & 25 & & & 35 & 4 & 8 & - & 15 & - \\
\hline Scaphognathite setae & $4+2$ & $13+2$ & & & $35+4$ & 5 & - & - & - & - \\
\hline \multicolumn{11}{|l|}{ Apical setae on exopods } \\
\hline Maxilliped I & 4 & 4 & & & 4 & 4 & - & - & 6 & - \\
\hline Maxilliped II & 5 & 6 & & & 6 & 6 & - & - & - & - \\
\hline Maxilliped III & 5 & 6 & & & 5 & 6 & - & - & - & - \\
\hline Exopods on pereopods & 1 rud & 1 rud & & & 0 & 0 & 0 & 1 & 1 & 1 \\
\hline Pleopods & + & + & & & + & 0 & 0 & 0 & bud & + \\
\hline Telson spines & $8+8$ & $8+8$ & & & $8+8$ & $7+7$ & $8+8$ & $8+8$ & $8+8$ & - \\
\hline Spine on abd. somite & 5 & 5 & & & 0 & 5 & 5 & 5 & 5 & 0 \\
\hline Med. spine on abd. somite & 0 & 0 & & & 0 & 3 & 3 & 3 & 3 & 0 \\
\hline
\end{tabular}

TABLE 11. Summary of characteristics of hermit crabs Pagurus acadianus (Roberts $(1968,1973)$ ) and $P$. pubescens present observations.

\begin{tabular}{|c|c|c|c|c|c|c|c|c|}
\hline & \multicolumn{4}{|c|}{ Stages of Pagurus acadianus } & \multicolumn{4}{|c|}{ Stages of Pagurus pubescens } \\
\hline & I & II & III & IV & I & II & III & IV \\
\hline Total length $(\mathrm{mm})$ & 3 & 4 & 5 & 6 & 4 & 6 & 7 & 8 \\
\hline Antennal scale $L X W$ & \multicolumn{4}{|c|}{$5-7$ times } & 9 & 9 & 7 & 11 \\
\hline Antennal flagellum & \multicolumn{4}{|c|}{ styliform } & \multicolumn{4}{|c|}{ bifid } \\
\hline Antennal scale setae & 7 & 8 & 7 & 7 & 6 & 8 & 8 & 9 \\
\hline Scaphognathite setae & 5 & 7 & 10 & 15 & $1(?)$ & 4 & 8 & 14 \\
\hline \multicolumn{9}{|l|}{ Exopod setae } \\
\hline Maxilliped I & 4 & 7 & 8 & 8 & 4 & 6 & 5 & 8 \\
\hline Maxilliped II & 4 & 7 & 8 & 8 & 4 & 6 & 6 & 8 \\
\hline Maxilliped III & - & 6 & 6 & 7 & - & 6 & 6 & 8 \\
\hline Uropod expod setae & \multicolumn{4}{|c|}{$4+1$ spine } & \multicolumn{4}{|c|}{$5+2$ spines } \\
\hline
\end{tabular}


TABLE 12. Summary of characteristics of spider crabs Hyas araneus (Christiansen, 1973) and Hyas coarctatus (Christiansen, 1973 and present observations). Present observations are given in parentheses.

\begin{tabular}{|c|c|c|c|c|}
\hline & \multicolumn{2}{|c|}{ Stages of Hyas araneus } & \multicolumn{2}{|c|}{ Stages of Hyas coarctatus } \\
\hline & I & II & I & II \\
\hline \multicolumn{5}{|l|}{ Sizes at Stages $(\mathrm{mm})$} \\
\hline tip dorsal-tip rostral spine) & 4 & 5 & $3(4-5)$ & $4(5-6)$ \\
\hline \multicolumn{5}{|l|}{ Outermost spinules on distal } \\
\hline two-thirds of rostral spine & \multicolumn{2}{|c|}{$\begin{array}{l}\text { Moderate } \\
\text { Shorter than spine width }\end{array}$} & \multicolumn{2}{|c|}{$\begin{array}{c}\text { Stout } \\
\text { Longer than width of rostral spine }\end{array}$} \\
\hline Scaphognathite setae & $7-9$ & $15-20$ & $8-10(12)$ & 19-22 (25) \\
\hline Spine on abdominal somite 5 & \multicolumn{2}{|c|}{ Short } & \multicolumn{2}{|c|}{ Shorter than in $\mathrm{H}$. araneus } \\
\hline
\end{tabular}


Index of Scientific Names 



\section{Index of Scientific Names}

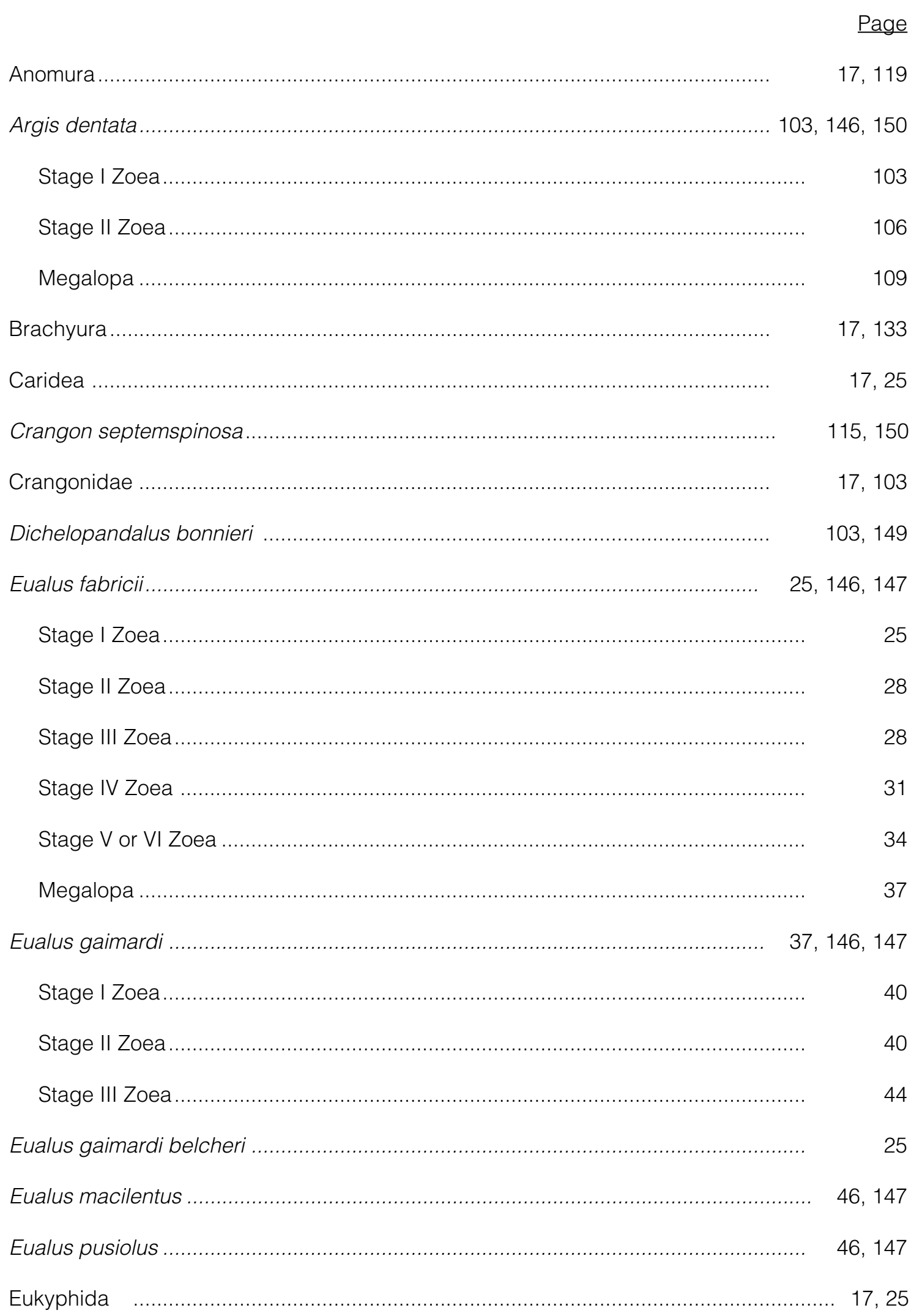




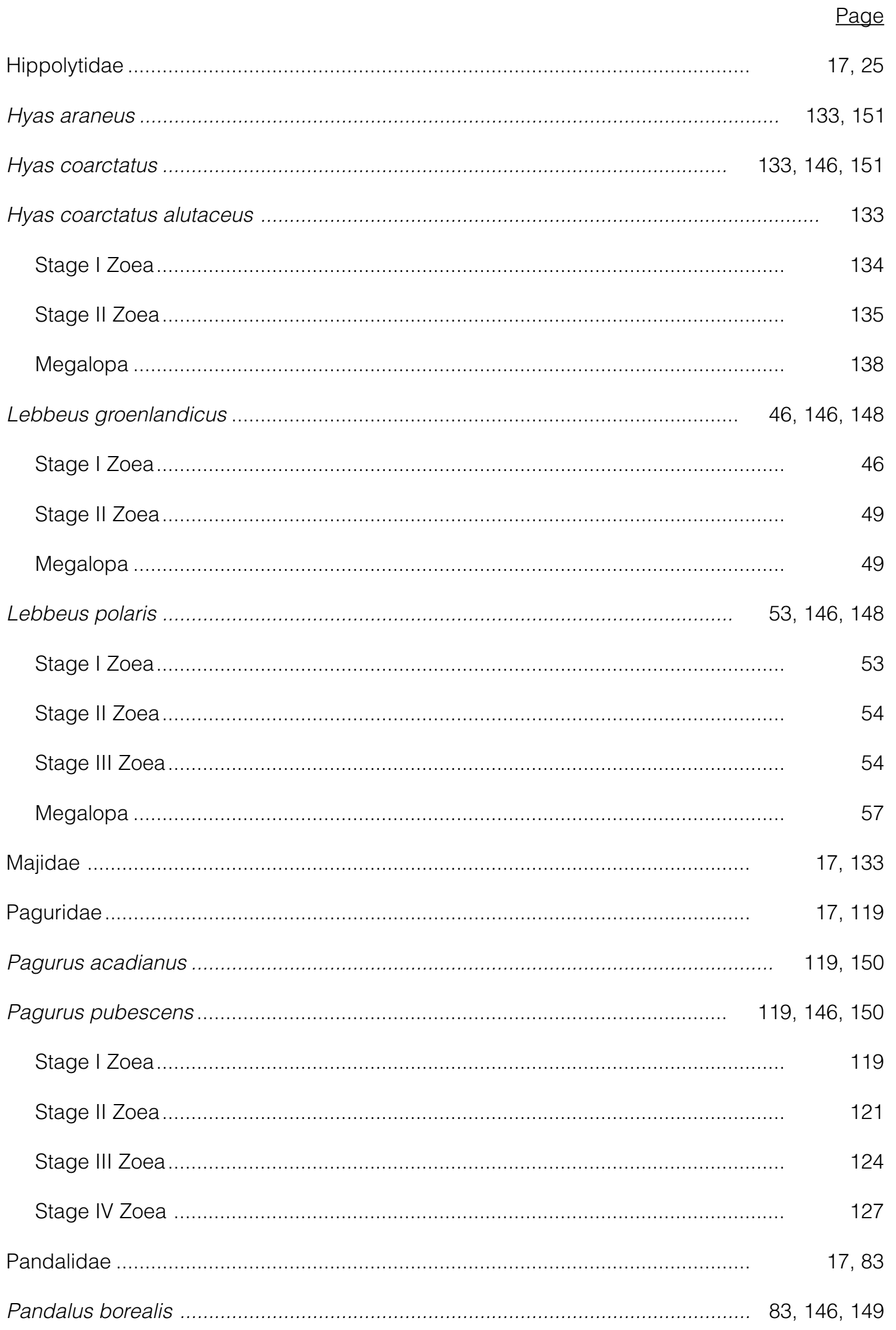




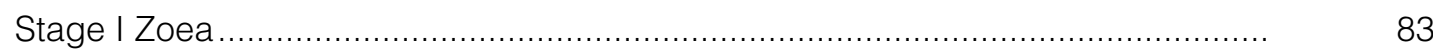

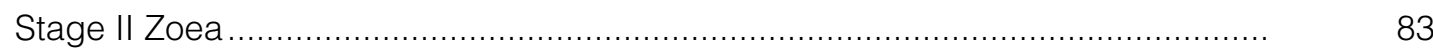

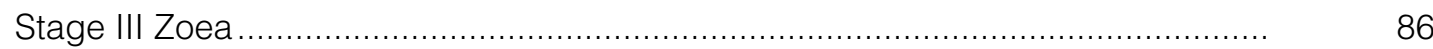

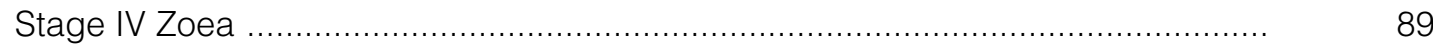

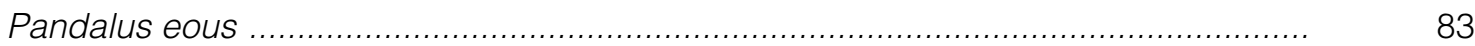

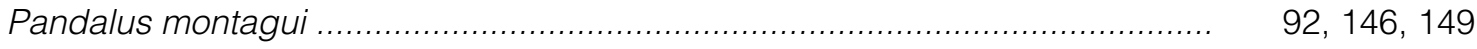

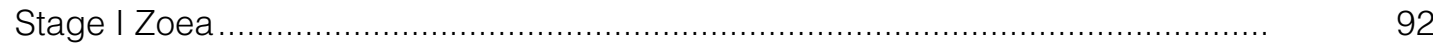

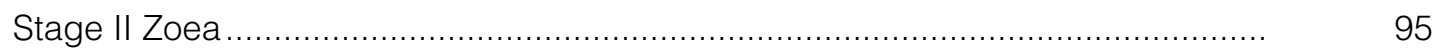

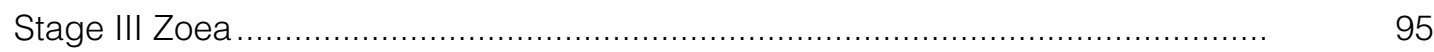

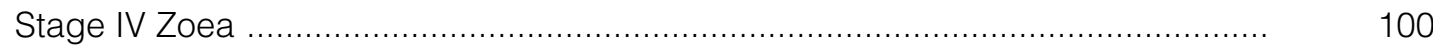

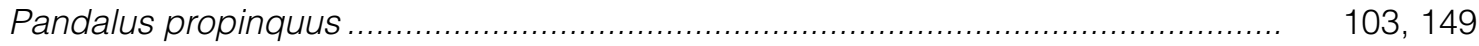

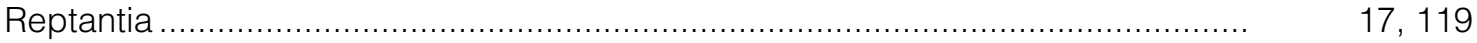

Sabinea septemcarinata …...................................................... 112, 146, 150

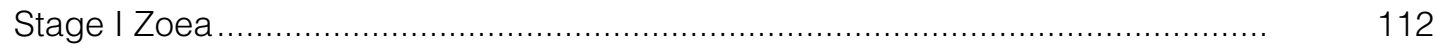

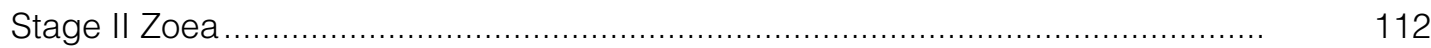

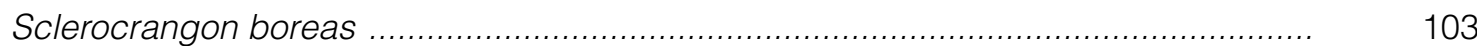

Spirontocaris phippsi .................................................................. $60,146,148$

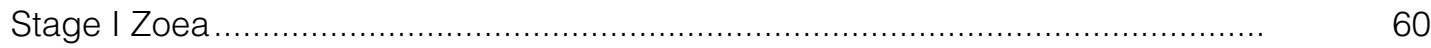

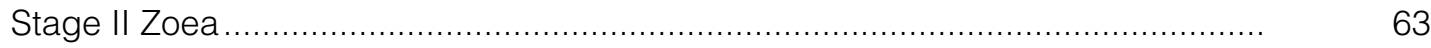

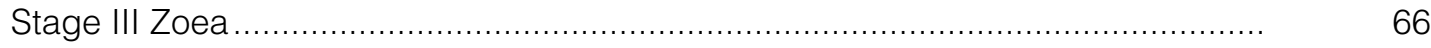

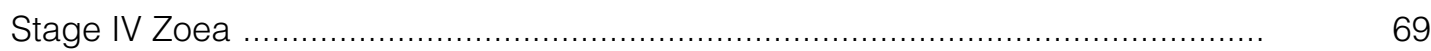

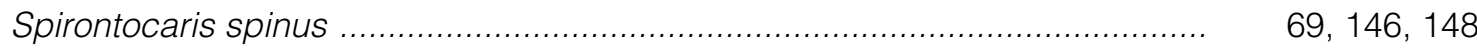

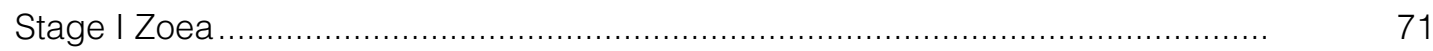

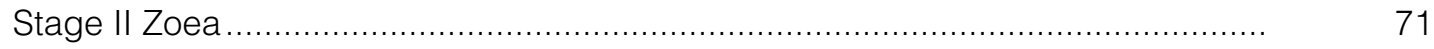

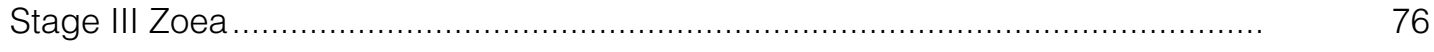

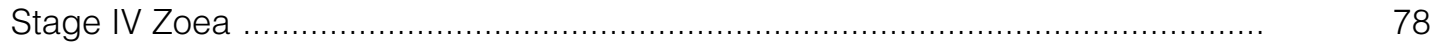

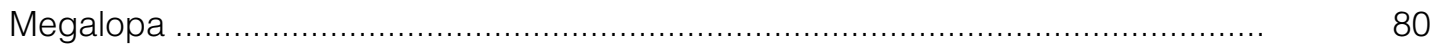

